\title{
Test Excavations and Monitoring at 41BX1598 A Multicomponent Historic Site in Bexar County, Texas
}

Antonia L. Figueroa

Center for Archeological Research, University of Texas at San Antonio

Raymond P. Mauldin

Center for Archeological Research, University of Texas at San Antonio

Follow this and additional works at: https://scholarworks.sfasu.edu/ita

Part of the American Material Culture Commons, Archaeological Anthropology Commons, Environmental Studies Commons, Other American Studies Commons, Other Arts and Humanities Commons, Other History of Art, Architecture, and Archaeology Commons, and the United States History Commons

Tell us how this article helped you.

This Article is brought to you for free and open access by the Center for Regional Heritage Research at SFA ScholarWorks. It has been accepted for inclusion in Index of Texas Archaeology: Open Access Gray Literature from the Lone Star State by an authorized editor of SFA ScholarWorks. For more information, please contact cdsscholarworks@sfasu.edu. 
Test Excavations and Monitoring at 41BX1598 A Multicomponent Historic Site in Bexar County, Texas

\section{Creative Commons License}

\section{(c) (1) \&}

This work is licensed under a Creative Commons Attribution-NonCommercial 4.0 International License 


\title{
Test Excavations and Monitoring at 41BX1598 A Multicomponent Historic Site in Bexar County, Texas
}

\author{
by \\ Antonia L. Figueroa \\ and \\ Raymond P. Mauldin \\ with contributions by \\ J. Phil Dering, Barbara A. Meissner, and I. Waynne Cox
}

Steve A. Tomka

Principal Investigator

Prepared for:

SpawGlass

9331 Corporate Drive

Selma, TX 78154

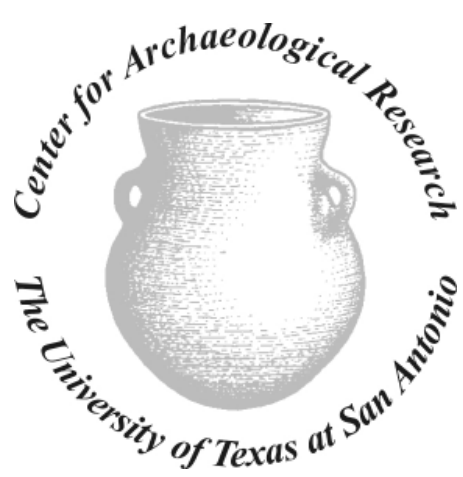

Prepared by:

Center for Archaeological Research

The University of Texas at San Antonio

Archaeological Report, No. 360 
A list of publications offered by the Center for Archaeological Research is available. Call (210) 458-4378; write to the Center for Archaeological Research, The University of Texas at San Antonio, 6900 N. Loop 1604 W., San Antonio, Texas 78249-0658; e-mail to car@lonestar.utsa.edu; or visit CAR's web site at http://car.utsa.edu. 


\section{Abstract}

From September through December of 2003, the Center for Archaeological Research (CAR) at The University of Texas at San Antonio performed archaeological testing and monitoring at site 41BX1598, the location for the proposed San Fernando Community Center. The site is adjacent to Military Plaza in downtown San Antonio, Bexar County, Texas. The work performed by CAR was done under contract with the San Antonio Archdiocese, and was conducted in accordance with and under the jurisdiction of the City Preservation Ordinance (Article VI, Historic Preservation and Urban Design, City of San Antonio, Unified Development Code). Dr. Steve Tomka served as the Principal Investigator and Antonia Figueroa was the Project Archaeologist. The proposed San Fernando Community Center will consist of a City Public Service (CPS) vault for utilities, two parking areas, and one large Community Center building. The initial phase of construction work consisted of excavations associated with the construction of the CPS vault. CAR's involvement in the project was initiated after that excavation was complete and it became evident that the vault excavation cut through what appeared to be Colonial-age deposits. Using a variety of methods, including archival research, backhoe trenches, shovel tests, and hand excavations, CAR archaeologists sampled two Colonial-age middens, recorded a variety of wall segments, including one which may be Colonial in age, and documented use of the location from the $1700 \mathrm{~s}$ through the early 1900s. Our work at the site recovered over 1,400 ceramics, 174 pieces of metal, 181 fragments of glass, 291 pieces of chipped stone debitage, two projectile points, six gun flints, more than 13,000 fragments of animal bone, and numerous pieces of burned rock. The remains of several domesticated and wild taxa, including bison, antelope, and fish, were recovered from the middens. Flotation analysis of matrix from one of the middens produced charcoal from a variety of different locally available woods, and while several carbonized mesquite seeds and nut shell fragments (pecan) were recovered, no domesticated species were present in the ethnobotanical samples. Analysis of the faunal material from the middens suggests the possibility that subsistence changed during the Colonial period. Faunal remains from the earliest deposits are dominated by small body sized animals, while later deposits reflect an increased emphasis on large and very large mammals. The stratified nature of selected midden deposits also allowed us to question some of the commonly assumed date ranges for selected ceramic types.

Following the completion of field work, CAR obtained site trinomial 41BX1598 for the location from the Texas Archeological Research Laboratory in Austin. After analysis, the bone and the burned rock were discarded in conformance with Texas Historical Commission guidelines and in agreement with the City of San Antonio Historic Preservation office. The remaining artifacts, along with all associated field and laboratory notes, project maps, photos, and other documents, are curated at the Center for Archaeological Research at The University of Texas at San Antonio under this trinomial. 


\section{Table of Contents:}

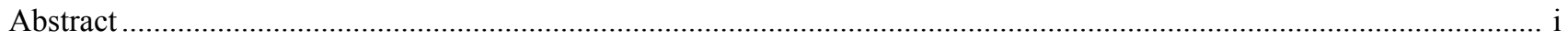

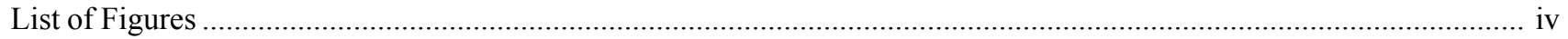

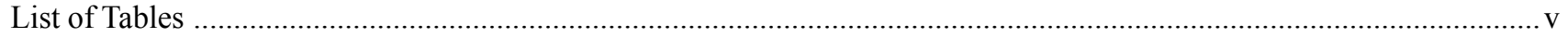

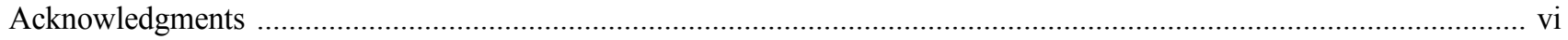

Chapter 1: Introduction

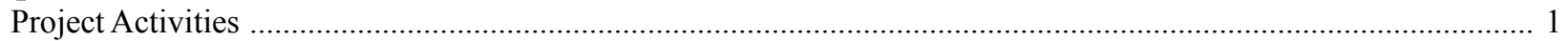

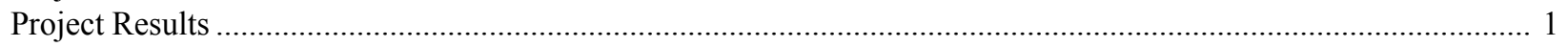

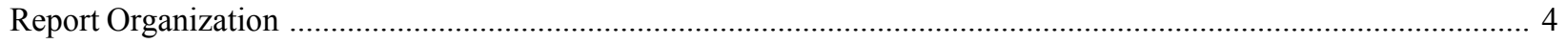

Chapter 2: Historic Background

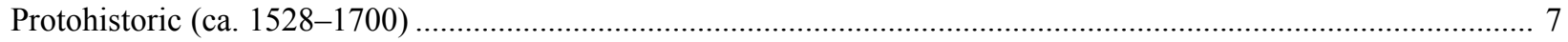

The Colonial and Mission Period in San Antonio (ca. 1700-1800) ……................................................................ 7

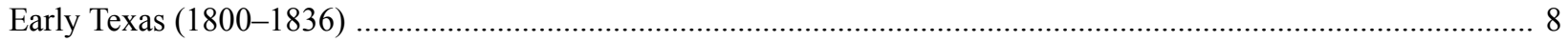

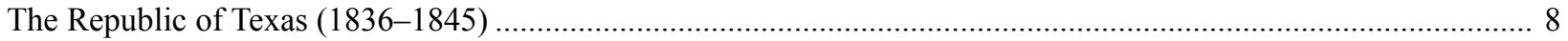

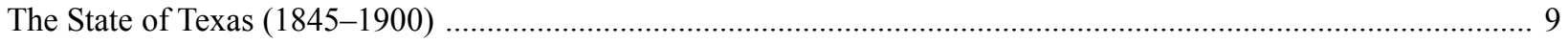

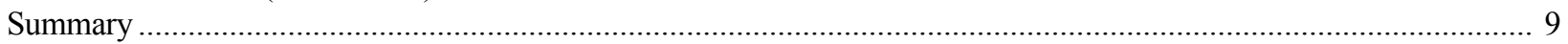

Chapter 3: Previous Archaeological Investigations

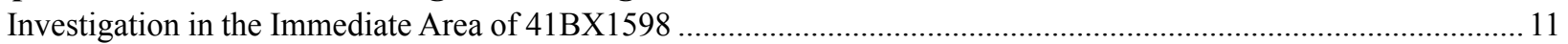

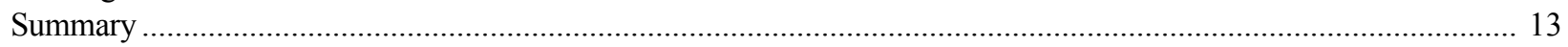

Chapter 4: Archival Research

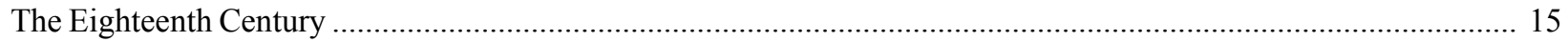

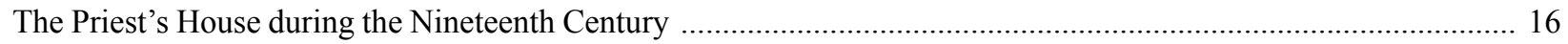

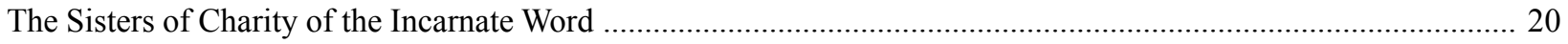

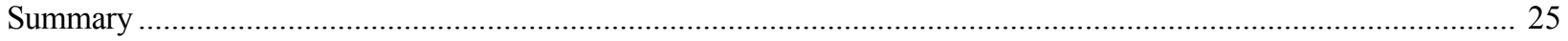

\section{Chapter 5: Project Activities}

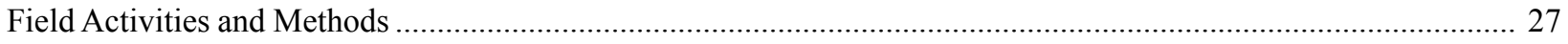

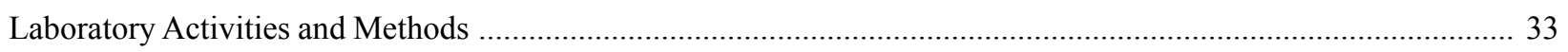

Chapter 6: Project Results

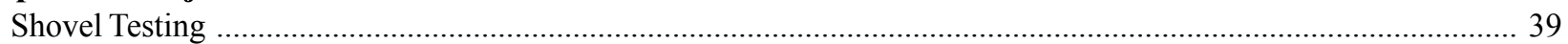

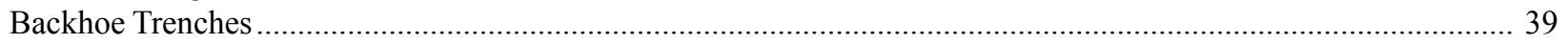

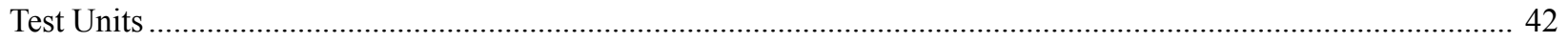

Chapter 7: Artifact Descriptions

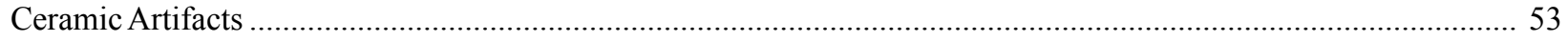

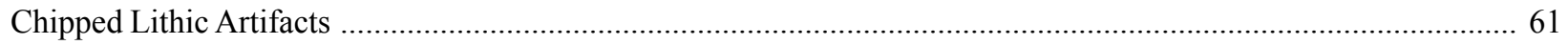

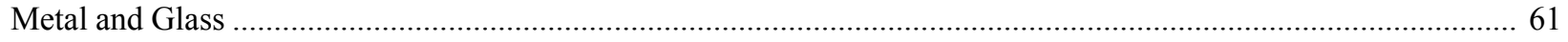

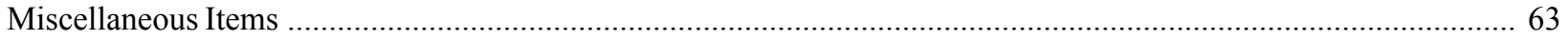

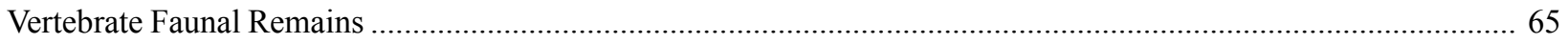

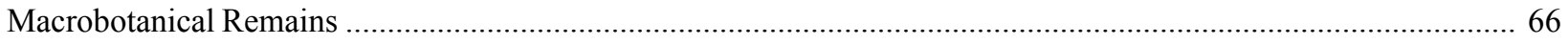

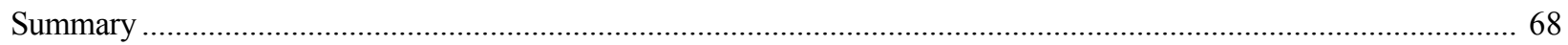

Chapter 8: Architecture and Features

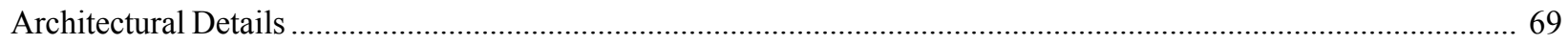

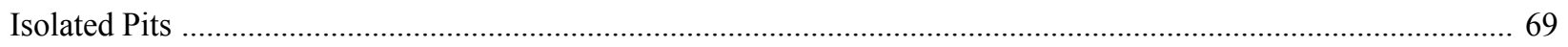

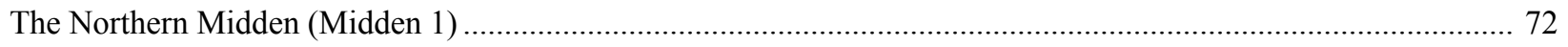

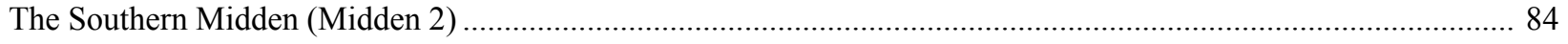


Midden Comparisons

Summary .....

\section{Chapter 9: Summary and Conclusions}

Summary and Conclusions

\section{References Cited}

References Cited.

\section{Appendix A}

Vertebrate Faunal Remains Recovered from 41BX1598

Appendix B

Macrobotanical Remains Identified from 41BX1598

\section{Appendix C}

Artifacts Recovered during Overburden Removal

\section{Appendix D}

History of the "Priest's House" on Military Plaza 


\section{Figures:}

Figure 1-1. Project area, with proposed community center (red) and parking areas (yellow) outlined. Note

City Public Service (CPS) vault (purple) in northwest section of property. ............................................................. 2

Figure 1-2. Photo of vault excavation area at time of CAR involvement. ..................................................................... 3

Figure 1-3. Photo of southern exposure of vault excavation area. Inset shows close-up of Colonial deposits

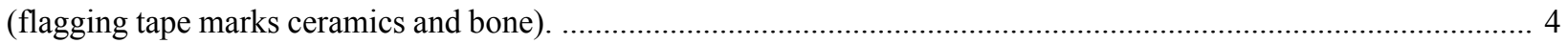

Figure 3-1. A map of downtown San Antonio showing archaeological investigations in the project area. ...................... 12

Figure 4-1. A portion of Joseph Urrutia's map of San Antonio de Bexar in 1767. ...................................................... 15

Figure 4-2. Detail of Luis Antonio Menchaca's 1764 map of San Antonio de Bexar, facing east, showing approximate

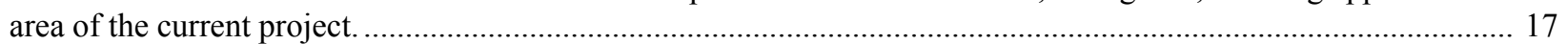

Figure 4-3. A map of the project area overlain onto an undated early map of San Antonio. ......................................... 18

Figure 4-4. The project area shown on a map from Yoakam 1855 ...................................................................... 19

Figure 4-5. The location of the "Priest's House" along the western portion of the project area. .................................... 20

Figure 4-6. Photograph showing the rear of the Santa Rosa Infirmary constructed in 1869. ......................................... 21

Figure 4-7. Sanborn map of the project area, dated 1877. ..................................................................................... 22

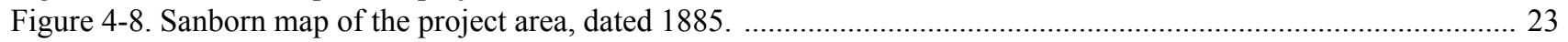

Figure 4-9. Sanborn map of the project area, dated 1911..................................................................................... 24

Figure 5-1. Approximate area of initial mechanical stripping at 41BX1598 ............................................................... 28

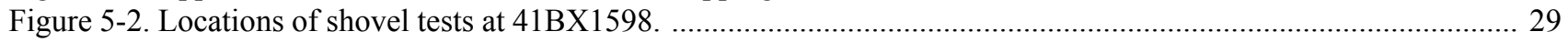

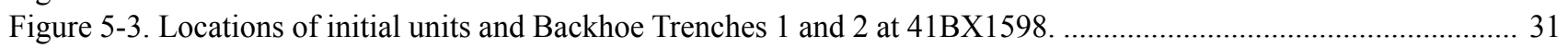

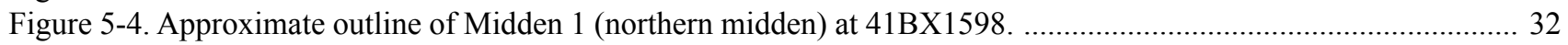

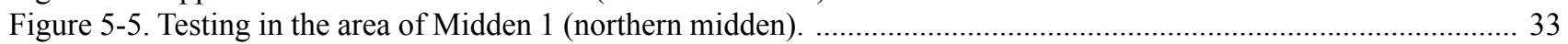

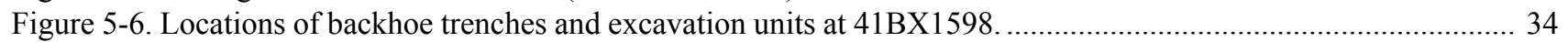

Figure 5-7. Locations of excavation units within Midden 2 (southern midden) at 41BX1598. .................................. 35

Figure 5-8. Photograph of the wall profile of Midden 2 (southern midden), looking east. ............................................ 36

Figure 5-9. Photograph of the initial bladed area, looking north. ......................................................................... 36

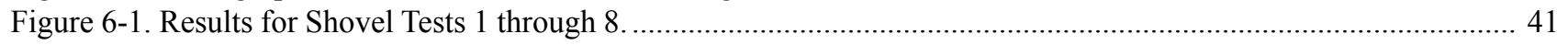

Figure 6-2. Section of Backhoe Trench 1, showing zonation visible in these deposits. ............................................... 42

Figure 6-3. Profile of portion of Backhoe Trench 1 with zones identified. ..................................................................... 44

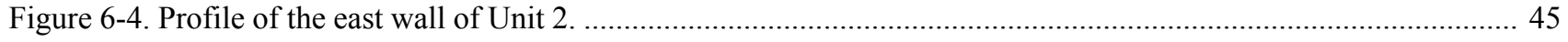

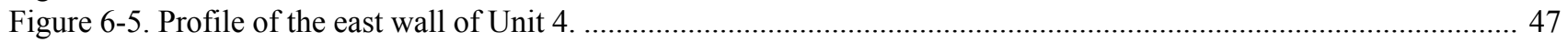

Figure 6-6. Profile of the west wall of Midden 2 (southern midden), with location of Unit 6 outlined. .......................... 49

Figure 7-1. Approximate age range of English and Spanish Colonial ceramic wares recovered from 41BX1598.......... 54

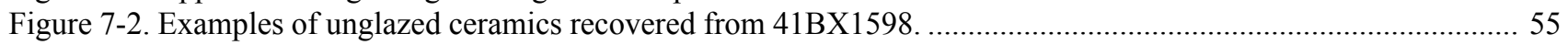

Figure 7-3. Example of lead-glazed ceramics recovered from 41BX1598. ........................................................... 56

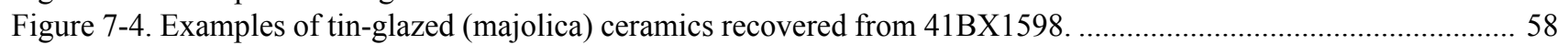

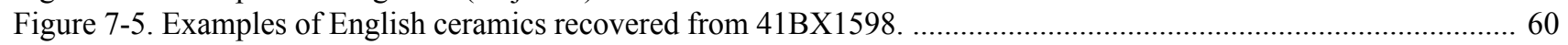

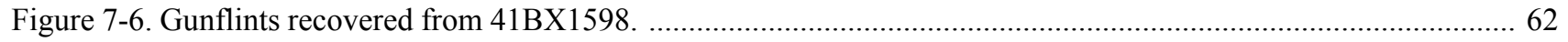

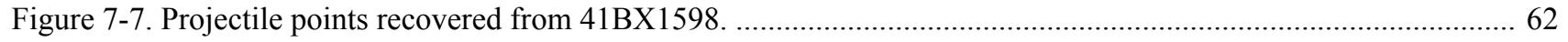

Figure 7-8. Copper bell, probably dating to the period of the St. Joseph's Orphan Asylum. ......................................... 63

Figure 7-9. Possible silver coins or medallions recovered from Midden 2 (southern midden). ........................................ 64

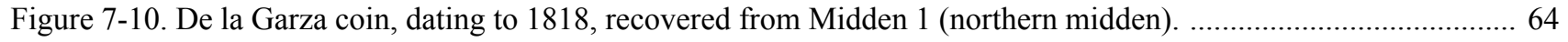

Figure 7-11. Marble plaque $(50 \times 30 \mathrm{~cm})$ recovered during surface stripping at 41BX1598. ......................................6 65

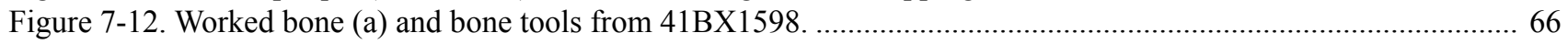

Figure 8-1. Wall and foundation segments uncovered during archaeological investigations. ......................................... 70

Figure 8-2. Probable correspondence between recorded wall alignments and archival maps. ......................................... 71

Figure 8-3. Overview of possible Colonial-period wall segment paralleling Camaron Street. ........................................ 72

Figure 8-4. Possible Colonial-period wall foundation in the southwestern portion of the project area. ........................... 73

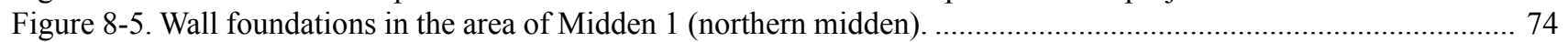


Figure 8-6. Locations of pit features (nos. 1-6) and middens at 41BX1598.............................................................. 75

Figure 8-7. Profile of portion of Backhoe Trench 1, through northern midden (Midden1). ........................................... 76

Figure 8-8. Line graph of number of items per $0.1 \mathrm{~m}^{3}$ of sediment for depositional zones in northern midden (Midden 1).

Figure 8-9. Line graph of bone weight per $0.1 \mathrm{~m}^{3}$ of sediment for depositional zones in northern midden (Midden 1).

Figure 8-10. Dated ceramic types recovered in the northern midden (Midden 1) .................................................... 83

Figure 8-11. The southern midden (Midden 2) prior to excavation, with upper and lower deposits identified. ................ 84

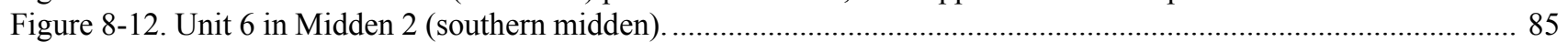

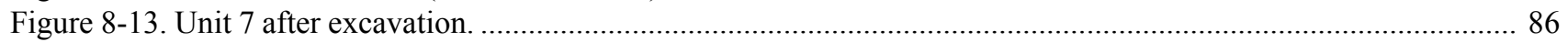

Figure 8-14. Line graph of number of items per $0.1 \mathrm{~m}^{3}$ of sediment for levels in southern midden (Midden 2). ............ 87

Figure 8-15. Line graph of bone weight per $0.1 \mathrm{~m}^{3}$ of sediment for levels in southern midden (Midden 2) ................... 88

Figure 8-16. Ceramic types recovered in the upper and lower deposits in the southern midden (Midden 2), .................. 89

Figure 8-17. Graph showing percentage of artifacts within a given group for the three different midden

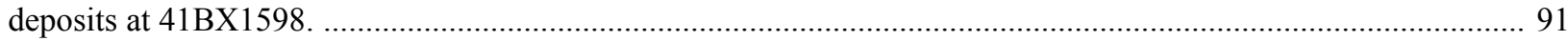

Figure 8-18. Graph showing percentage of faunal remains by body size groupings for the midden deposits at $41 \mathrm{BX} 1598$.

\section{Tables:}

Table 6-1. Material Recovered from Shovel Tests 1-9, by Depth ........................................................................... 40

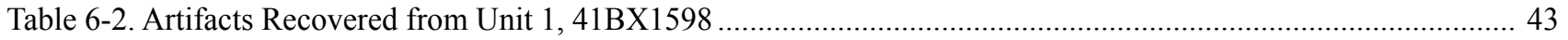

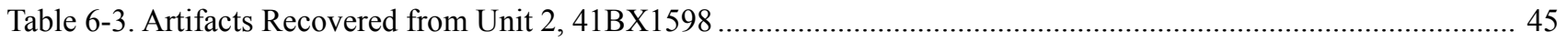

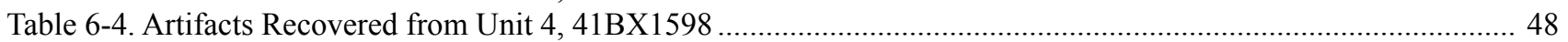

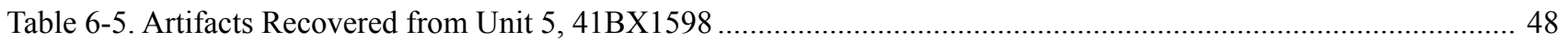

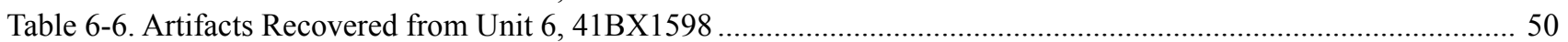

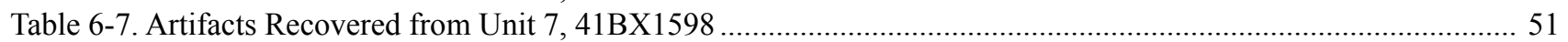

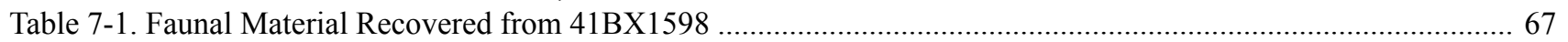

Table 7-2. Wood Recovery from Flotation Samples in Northern Midden (Midden 1) ...................................................... 68

Table 8-1. Artifact Densities for Units Excavated in Midden 1 (northern midden) ........................................................ 77

Table 8-2. Observed Ceramic Counts and Adjusted Residuals for Units 1, 2, 4, and 5 (Midden 1) ................................. 78

Table 8-3. Observed Colonial and English Ceramic Counts and Adjusted Residuals for Unit 1 .................................. 80

Table 8-4. Observed Colonial and English Ceramic Counts and Adjusted Residuals for Unit 2 ................................... 80

Table 8-5. Observed Colonial and English Ceramic Counts and Adjusted Residuals for Unit 4 ................................. 81

Table 8-6. Observed Colonial and English Ceramic Counts and Adjusted Residuals for Unit 5 ................................. 82

Table 8-7. Artifact Densities by Types for Southern Midden (upper and lower) and Northern Table .............................. 86

Table A-1. Vertebrate Faunal Remains Recovered from 41BX1598 ….................................................................. 104

Table B-1. Plants Identified in Flotation Samples Recovered from 41BX1598 …...................................................... 117

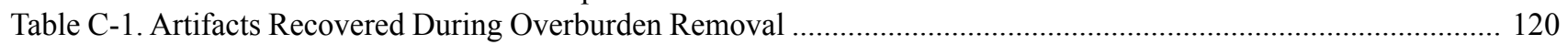




\section{Acknowledgments}

Thanks first and foremost to the field crew for their hard work on the site. At various times, Leonard Kemp, Barbara Meissner, Bruce Moses, Cindy Muñoz, Bryant Saner, Steven Tomka, Stacy Wagner, Jason Weston, and Steven Troell helped out with excavation, monitoring, and mapping tasks. The authors would also like to thank the San Antonio Archdiocese, SpawGlass contractors, and Sprinkle Robey Architects for their cooperation and patience during investigations of the project area. Special thanks to Father David Garcia, Laurie Mckinny-Buckner, Rachel Epperson, Joe Robbins, Martin Sanchez, David Laureano, Juan Riojas and Rene Balderas. We also acknowledge and appreciate the support of the San Antonio Conservation Society. We would like to thank Kay Hindes of the City of San Antonio Historic Preservation Office and Mark Denton of the Texas Historical Commission for their input and cooperation. We are indebted to several individuals who shared their knowledge of the area and its history, especially the Sisters of Incarnate Word, Mr. Clint McKenzie, and Ms. Anne Fox. Barbara Meissner conducted the faunal analysis and Dr. Phil Dering conducted the ethnobotanical work. Laboratory processing was overseen by Antonia Figueroa, under the direction of Marybeth Tomka. Thanks also to Anne Fox and Kristi Ulrich for help with the ceramic identifications. The excellent graphics in this report were done by Bruce Moses and Rick Young. Editing tasks and report production were undertaken by Johanna Hunziker and Claudia Branton. Thanks to all. Finally, thanks to Waynne Cox. Waynne passed away during the production of this report. He dropped by the site several times during the fieldwork and he was always more than willing to share his knowledge and humor. Waynne authored Appendix D of this report. His dedication to documenting and understanding San Antonio's past continues to be an inspiration to us all. We miss him. 


\section{Chapter 1: Introduction}

Through the months of September and December of 2003, the Center for Archaeological Research (CAR) of The University of Texas at San Antonio performed archaeological testing and monitoring at site 41BX1598, the location of the proposed San Fernando Community Center in the city of San Antonio, Bexar County, Texas. The project is located adjacent to Military Plaza (Plaza de Armas), on the corner of Commerce and Camaron streets in downtown San Antonio (San Antonio East 7.5' USGS quadrangle), and is a significant historical area in the city. The work performed by CAR was done under contract with the San Antonio Archdiocese, and in conjunction with Sprinkle Robey Architects and SpawGlass contractors. Agency oversight was provided by the City of San Antonio Historic Preservation Office, and the work was conducted in accordance with and under the jurisdiction of the City Preservation Ordinance (Article VI, Historic Preservation and Urban Design, City of San Antonio, Unified Development Code). Dr. Steve Tomka served as the Principal Investigator and Ms. Antonia Figueroa was the Project Archaeologist.

\section{Project Activities}

The proposed San Fernando Community Center will consist of a City Public Service (CPS) vault for utilities, two parking areas, and one large Community Center building that dominates the lot (Figure 1-1). The project area is roughly 0.985 acres in size, and the construction necessitated the removal of roughly six to eight feet (ca. 1.83 to 2.44 meters [m]) of fill for the construction of the Community Center building, an area that covers the majority of the project (ca. 0.523 acres). The initial phase of construction work consisted of excavating a roughly 0.12 -acre $\left(500 \mathrm{~m}^{2}\right)$ hole, roughly 21 feet $(6.4 \mathrm{~m})$ deep, for the construction of the CPS vault (Figures 1-1 and 1-2). CAR's involvement in the project was initiated after that excavation was complete. The vault excavation cut through what appeared to be Colonial-age (ca. 1700-1800) deposits, with significant quantities of ceramic and bone exposed in the southern face of the vault excavation (Figure 1-3). As a result of this discovery, CAR was contacted by representatives of the Archdiocese of San Antonio, and in consultation with the City of San Antonio Historic Preservation office, initiated a series of activities designed to (1) determine the nature and extent of the Colonial deposits, (2) design a strategy for sampling those deposits, (3) monitor additional construction activities to insure that other such deposits, if encountered, would be sampled, and (4) conduct archival research on the property to document any historically important uses of the location.

In order to determine the nature and extent of the Colonial deposits exposed by the vault construction, as well as to obtain samples of those materials, CAR used a variety of methods, including the excavation of nine shovel tests, mechanical stripping of deposits, hand excavation of four $1-\mathrm{x}-1-\mathrm{m}$ units and a single $50-\mathrm{x}-50-\mathrm{cm}$ unit, and the excavation of two backhoe trenches adjacent the vault. Backhoe trenching, in combination with mechanical stripping, were used to explore the remaining portions of the project area. In addition, one 1-x-1-m unit and one $50-\mathrm{x}-50-\mathrm{cm}$ unit were excavated in a second midden discovered on the southern end of the project area. In all, about $4.56 \mathrm{~m}^{3}$ of earth was screened from the hand-excavated units. In addition, six backhoe trenches, covering roughly $103.8 \mathrm{~m}^{2}$, were excavated. Archival research involved reference to Sanborn Insurance Maps, as well as a variety of other historic maps and documents.

\section{Project Results}

Archival research suggested that while a variety of construction events had taken place on the property, the western and southern portions of the property had the greatest likelihood of containing intact deposits dating prior to 1850 . Any significant deposits on the eastern side of the property were likely to have been destroyed during construction of a large hardware store, with an accompanying basement, in the early 1900s. In addition, archival records suggest that the southern section of the property, which is bordered by West Commerce Street (see Figure 1-1), was possibly immediately adjacent to, abutted, or included portions of the northern wall of the second location of the Presidio San Antonio de Béxar (Habig 1977:25).

Archaeological investigations performed by CAR resulted in the confirmation of many aspects of these archival records. Specifically, portions of a series of buildings that housed the Santa Rosa Infirmary, and subsequently the St. Joseph's Orphan Asylum, were uncovered on the western 


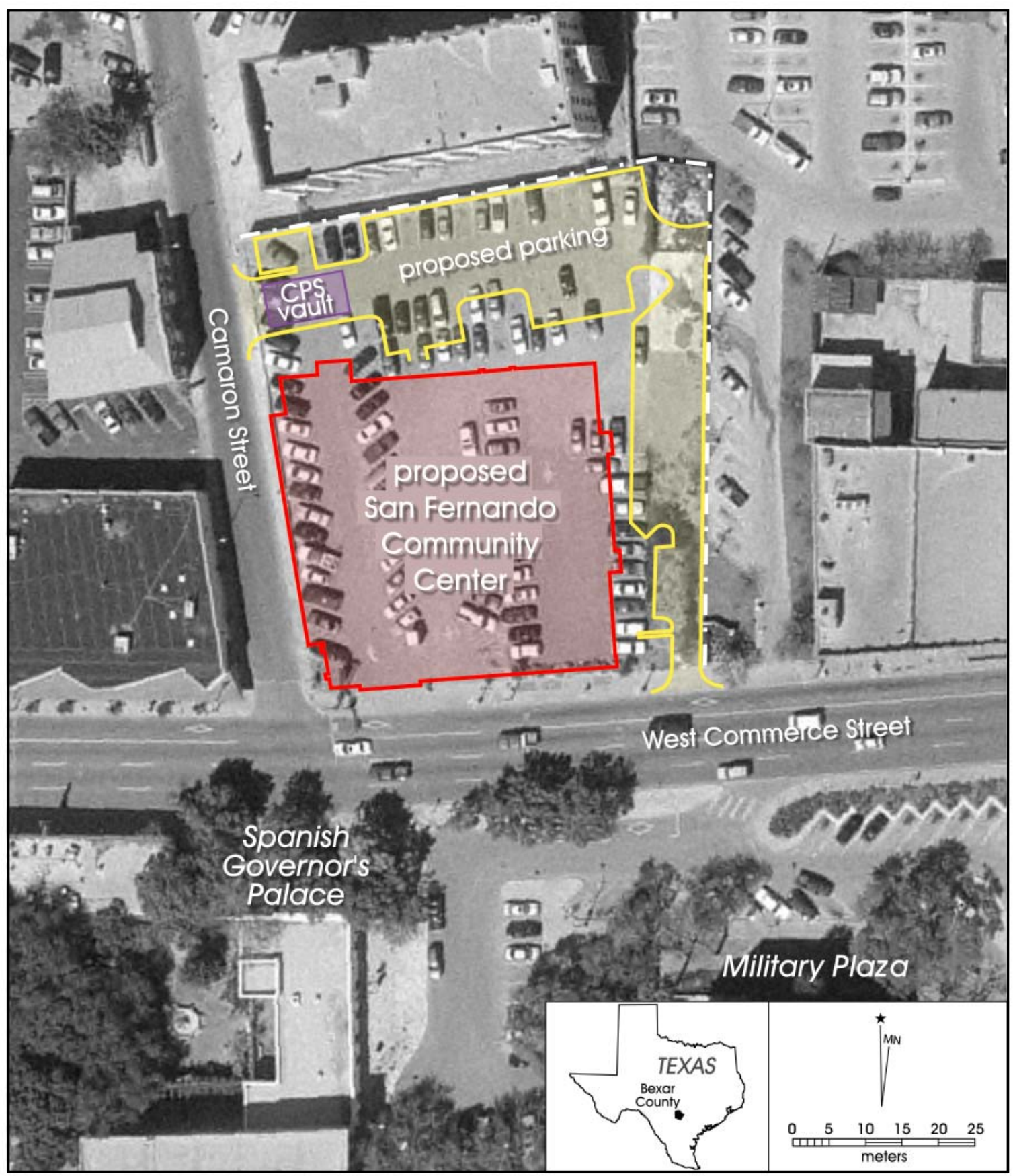

Figure 1-1. Project area, with proposed community center (red) and parking areas (yellow) outlined. Note City Public Service (CPS) vault (purple) in northwest section of property. 
section on the property. These buildings were originally constructed in 1869. Trenching on the eastern portion of the property confirmed the presence of the hardware store, suggesting that no significant deposits would be preserved in this section of the property. In addition, the archaeological work uncovered a portion of a wall, located on the southwestern corner of the property, which may date to the Colonial period and may be related to the Presidio, although this remains unclear. A series of features, including several recent trash pits, were uncovered in the backhoe trenches and during the stripping operations. Finally, CAR tested two Colonial-period trash middens. The initial trash midden, originally discovered during the CPS vault construction, contained clearly defined depositional zones and deposits ranging in age from 1750 to the 1860 s. A second midden was located during trenching and stripping operations on the southwestern portion of the property. Only a small portion of this midden remained. The second midden consisted of two distinct deposits. Based on ceramics, the upper deposit may be roughly contemporary with the northern midden. The lower deposit within this southern midden, which also demonstrated clear depositional lenses, dated earlier, perhaps spanning a period from roughly 1700 through 1800 , with the possibility that Protohistoric material was also present. Samples removed from these Colonial-period middens provided a variety of data types for analysis, including over 1,400 ceramics, over 170 pieces of metal, 291 pieces of chipped stone debitage, two projectile points, six gun flints, over 13,000 fragments of animal bone, 181 pieces of glass, and numerous pieces of burned rock. The remains of several domesticated and wild animals, including bison, antelope, and fish, were recovered from these middens. Flotation analysis from the northern midden produced charcoal from a variety of different woods, including mesquite, pecan, juniper, agarita, and willow/ cottonwood. No pine or other non-local woods were present.

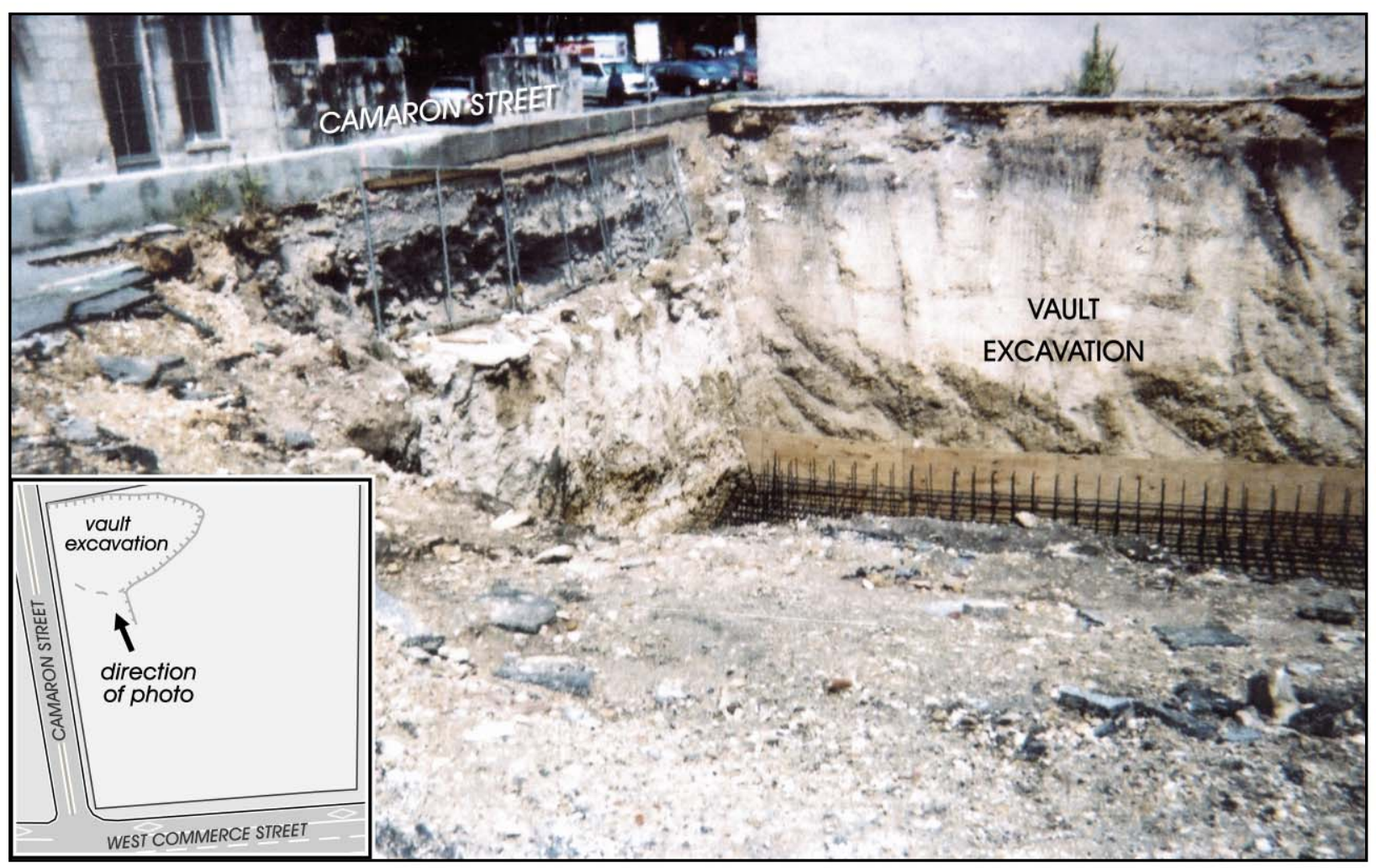

Figure 1-2. Photo of vault excavation area at the time of CAR involvement. 


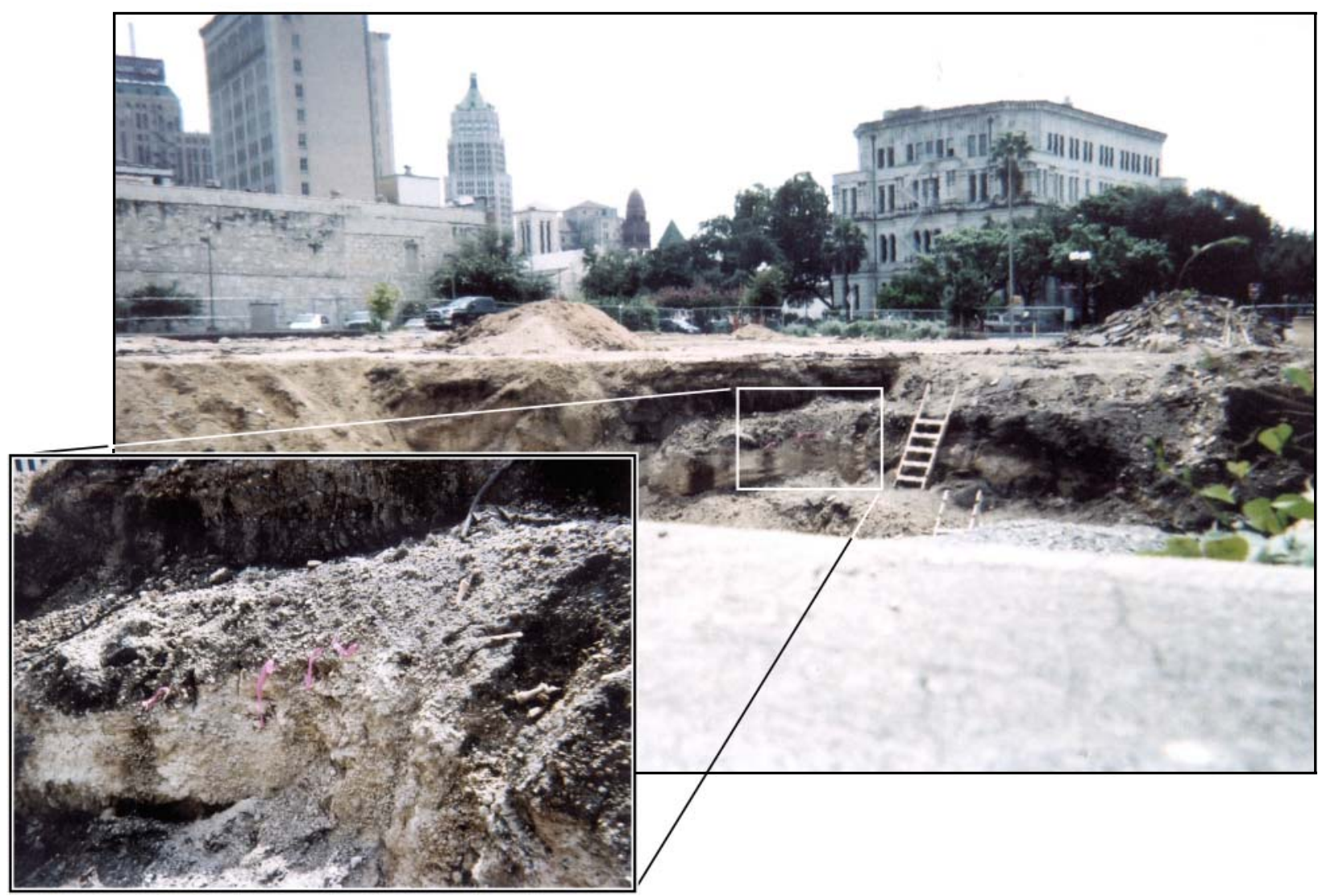

Figure 1-3. Photo of southern exposure of vaul excavation area. Inset shows close-up of Colonial deposits (flagging tape marks ceramics and bone).

In addition, while several carbonized mesquite seeds and nut shell fragments (cf. pecan) were recovered, no domesticated species were present in the ethnobotanical samples. Analysis of the faunal material from the middens suggests the possibility that subsistence, at least at this site, changed during the Colonial period. Faunal remains from the earliest deposits are dominated by small-sized animals, while later deposits reflect an increased emphasis on large and very large mammals, especially cattle. The stratified nature of the northern midden deposits also allow us to question some of the commonly assumed date ranges for selected ceramic types.

Following the completion of field work, CAR obtained site trinomial 41BX1598 for the location from the Texas Archeological Research Laboratory in Austin. After analysis, the bone and the burned rock were discarded, as agreed upon by the City of San Antonio Historic Preservation Office and CAR. The remaining artifacts, along with all associated field and laboratory notes, project maps, photos, and other documents, are curated at the Center for Archaeological Research at The University of Texas at San Antonio under this trinomial.

\section{Report Organization}

Including the present chapter, the report consists of nine chapters and four appendices. Chapter 2 provides historical background on the region, while Chapter 3 provides a short review of previous archaeological research on sites in the immediate area. Chapter 4 summarizes the results of the archival research, including documentation of the use of the property from the early 1700 s to the early 1960 s. 
Chapter 5 summarizes the field and laboratory activities associated with the project, including a discussion of the methods used. The sixth chapter discusses the project results. Chapter 7 provides detailed descriptions of artifacts encountered during this work, while Chapter 8 presents a more detailed analysis of the features and architectural data, including detailed analysis of the Colonial-period middens. Finally, the ninth and final chapter provides a summary of the project. Four appendices provide supporting information. Appendix A lists the vertebrate faunal remains recovered during the project. Appendix B provides ethnobotanical results from one of the two Colonial-period middens. Appendix $\mathrm{C}$ presents artifacts collected during overburden removal, and Appendix D provides a history of the "Priest's House" once located on the property. 



\section{Chapter 2: Historic Background}

As noted in the previous chapter, the proposed San Fernando Community Center project area is located adjacent to Military Plaza in downtown San Antonio. To place the project area into a historical context, this chapter provides brief discussions of several broad periods spanning from roughly 1530 through the early 1900s. Archival research, discussed in detail in Chapter 4, as well as material remains uncovered during excavation at 41BX1598, demonstrate that the project area was used initially during the Colonial period, though material remains consistent with pre-Colonial occupations are present. Therefore, we provide a brief review of major periods spanning the potential occupation of 41BX1598. These include the Protohistoric period, Colonial/Mission period, Early Texas period, The Republic of Texas, and the State of Texas up to the early 1900s.

\section{Protohistoric (ca. 1528-1700)}

The Protohistoric period is a term typically used to describe the transition between the Late Prehistoric and Historic periods. It is the least well documented period in Texas history. Some researchers (e.g., Wade 2003) argue that the Protohistoric period may coincide with the end of the Late Prehistoric Toyah Interval, spanning the period of A.D. $1250 / 1300$ to A.D. $1600 / 1650$ (Hester 1995). Here, we define the period as beginning with the Early Spanish explorations in Texas (ca. 1528) and ending with the establishment of a strong Spanish presence in the region in the late 1600 s and early 1700 s.

During the Protohistoric there was sporadic interaction between the native groups and Spanish explorers. It was a time before the Spanish economy significantly impacted the indigenous groups in the area. A number of encounters between the indigenous communities and Europeans were recorded during this period, including those with Cabeza de Vaca (1528-1536) and the French settlement established by René Robert Cavelier, Sieur de La Salle (1685-1689). Spurred on, in part, by the French presence, the Spanish sent General Alfonso de Leon into the area in 1689, and in 1691 the area of present-day San Antonio was first visited by Domingo de Teran (Fox and Cox 2000; Fox et al. 1997).
Archaeologically, this poorly documented Protohistoric period has been identified at several sites in south Texas counties (e.g., Hall et al. 1986; Inman et al. 1998; Mauldin et al. 2004). A problematic issue concerning this time period is that there is not a clear set of material culture associated with the period. Therefore, it is difficult to document this time period archaeologically without absolute dates. Sites that have been deemed as "Protohistoric" may have Late Prehistoric and/or Historic artifacts associated with them, and in several cases radiocarbon dates confirm their Protohistoric designation (e.g., Mauldin et al. 2004).

\section{The Colonial and Mission Periods in San Antonio (ca. 1700-1800)}

The first Spanish presidios (forts) in North America began to appear in 1565 with the establishment of San Agustin on the Atlantic coast of Florida (Moorhead 1991:27). The establishment of presidios was mainly due to the encroachment of European powers, predominantly the French (Moorhead 1991:27). The first attempt to have an established Spanish presence in Texas was the founding of Mission San Francisco de los Tejas, established in 1690 near Nacogdoches, and Santismo Nombre de Maria, built on the banks of the Neches River in that same year. Both attempts were short-lived, and by 1693, both were abandoned (Fox and Cox 2000). The founding of Mission San Juan Bautista in 1700 along the Rio Grande marked the beginning of an established Spanish presence in the region (Weddle 1968).

In 1718, Don Martín del Alarcón established Presidio San Antonio de Béxar and Mission San Antonio de Valero near the headwaters of San Pedro Creek (Fox 1997, after Chipman 1992:14; Hoffman 1937). In 1722, Marqués de Aguayo relocated the villa and presidio to their final locations on the west side of the San Antonio River. The presidio and the villa were named after the Duke of Béjar, the elder brother of the Viceroy (Buerkle 1976:50). The purpose of the San Antonio de Béxar presidio was not only to protect the mission, town, farms and ranches, but also serve as a way-station between Mexico and the East Texas settlements. After a four-month stay in East Texas, Alarcón 
returned to San Antonio where he faced challenges and problems with the missionary fathers (Buerkle 1976:51). After his request for additional soldiers, funds, and supplies was denied, Alarcón resigned from his position in 1719 (Buerkle 1976:51).

In 1719, Marques de San Miguel de Aguayo became the governor and captain general of Coahuila and Texas. He led an expedition into Texas to return Spanish presence to the frontier. Aguayo and his troops re-supplied in San Antonio before heading to East Texas for eight months. While in East Texas, Aguayo re-established the presidios and installed new missions (Buerkle 1976:52). Upon his return to San Antonio, he found that the granary at the presidio, along with several of the soldiers' jacales, had been destroyed by fire. Aguayo ordered that a new presidio be built of adobe. Harsh weather delayed the progress of the new presidio and it was apparently never completed. The construction never "progressed beyond two towers, a surrounding wall and some scattered wooden or jacal structures" (Fox 1997:2, after Buckley 1911).

The French attacked the East Texas mission San Miguel de los Adaes in 1719, resulting in the Spanish fleeing to San Antonio. In 1720, Mission San José y San Miguel de Aguayo was established in the area, followed by the missions Nuestra Señora de la Purisima Concepción de los Hainai, San Francisco de Espada and San Juan Capistrano.

The establishment of Villa de San Fernando occurred in 1731. The settlement was to be home to Canary Islanders (Isleños). The Islanders were brought to the area to establish a settlement made up of stable families. The Spanish King at the time was Phillip V, who promised the Canary Islanders a passage to the frontier of New Spain, free land, and maintenance for one year (Fox et al. 1997). The ranking status of hidalgo was another incentive granted to the new settlers. The villa became the first civil settlement of Texas. The settlement was planned east of the presidio and farmland was allotted to the Islanders. The majority of farmland was located between the San Antonio River and San Pedro Creek.

The Seven Year War began in 1756 and changed the dynamics of Spanish colonialism in Texas. The British replaced the French as a major threat to Spanish presence, and Spain had to fortify its settlements in Louisiana and California against indigenous groups. As a result of this shift in focus, East Texas settlements began to deteriorate and populations were relocated to San Antonio. During the latter part of the eighteenth century, the missions in San Antonio began to decline due to a shortage of priests and a decline in population and workers to maintain the agricultural fields. In 1790, Manuel Silva, under the College of Zacatecas, recommended Mission San Antonio de Valero be secularized. Furthermore, of the four remaining missions only two were still functioning. By 1794, Mission San Antonio de Valero was secularized and the surrounding lands distributed to the remaining Mission Indians and other individuals (see Appendix D).

\section{Early Texas (1800-1836)}

In 1802 the Compania Volante de San Carlos del Alamo de Parras from Coahuila occupied the Presidio de San Antonio de Béxar (see Appendix D). The soldiers were assigned quarters in the abandoned Mission San Antonio de Valero. It was at this time that the former mission became known as the Alamo. Inklings of unrest and discontent began in Mexico and Texas at this time. Mexico became independent from Spain in 1821. The 1824 Constitution became instituted merging Texas and Coahuila into one state, with San Antonio de Béxar as a separate department (Fox et al. 1997).

Spain's attempt to regain control of Mexico in 1829 failed. Stephen F. Austin asked San Antonio to provide support for his efforts to make Texas a separate entity in 1833 . In 1833 Santa Anna became the President of Mexico, and the following year he dispatched an army in the command of General Cós to put down a civil war in Coahuila and reinforce the garrisons in Texas.

General Cós and his troops were pushed out of San Antonio under Ben Milam in December of 1835. The Mexican army arrived in San Antonio in February 1836 and the Alamo and Texan troops were assaulted and defeated in early March of 1836. Santa Anna was finally defeated and caught at the Battle of San Jacinto, later that same year (Fox et al. 1997).

\section{The Republic of Texas (1836-1845)}

Sam Houston was inaugurated as the first president of the Republic of Texas in 1836. The Texas Congress set the boundaries for the newly formed republic (Nance 2004). The Rio Grande was declared the southern boundary and Louisiana the eastern border. The population of San Antonio increased due to immigration. The new city council of San Antonio elected John W. Smith as mayor in 1837. 
Mexico refused to recognize the independence of Texas and a formal state of war continued. General Rafael Vasquez, with 700 soldiers, attempted to take over San Antonio and the unprepared Texan force retreated to present-day Seguin. In 1842, a friend of Santa Anna, General Adrian Woll, captured San Antonio, and this time the Texans resisted. Finally, in 1844 a truce was called between Mexico and Texas (Fox et al. 1997).

\section{The State of Texas (1845-1900)}

On December 29, 1845, the United States Congress approved the Texas State Constitution and Texas was admitted as a state. This act, coupled with the failure to agree on the Rio Grande as a boundary and on the sale of California to the United States, resulted in the war between the United States and Mexico (1846-1848). In early 1846, General Zachary Taylor advanced to the Rio Grande, occupying land that the Mexican government viewed as its own, and war was declared in May of that year. After a series of battles, the United States military occupied Mexico City in August of 1847. In May of 1848, the ratification of the Treaty of Guadalupe Hidalgo by the Mexican government signaled the end to hostilities, established the Rio Grande as a boundary, and gave the United States present-day Arizona, California, New Mexico, Texas, and parts of Colorado, Nevada and Utah in exchange for \$15 million. United States troops left Mexico in June of that same year (Bauer 1974; Wallace 1965).

With the boundaries of Texas now established, the new state soon found itself embroiled in controversy over its position on slavery. The majority of the population within the state was derived from the south, and while ranching and subsistence farming were probably the major economic activities, cotton-based agriculture was the major cash crop. In 1846, Texas had more than 30,000 black slaves, many associated with cotton production. At the outbreak of the Civil War, thousands of Texans fought on both sides, with the effects of the war seen throughout Texas, including shortages of commodities in San Antonio. On June 19, 1865, General Gordon Granger arrived in Galveston with Union forces, signaling the end of the Civil War (Fox et al. 1997).

At the close of the war in 1865, a plague of cholera and floods struck the city of San Antonio. The Sisters of Charity arrived with aid for San Antonio in 1866 and started Santa
Rosa Hospital. As discussed in the subsequent chapter, in November of 1869 , a two-story building was constructed to house the Santa Rosa Infirmary at the current project location. The same facility subsequently housed the St. Joseph's Orphan Asylum in 1875 (Sanborn map 1885; Slattery 1995).

In February 1877, the Galveston, Harrisburg and San Antonio Railroad arrived in the area. With the arrival of the railroad, commercial elements were introduced into the area for the first time (Fox et al. 1997). A growth in business was created near the depot, including stores and saloons. City waterworks also commenced during this time, and the city continued to expand. At the beginning of the twentieth century, the population of San Antonio was just over 53,000 (Fox et al. 1997).

\section{Summary}

As noted in Chapter 1, the deposits uncovered at 41BX1598 appear to reflect that the property was used well before 1750 . The recovery of a variety of lithic tools hints at the possibility of earlier use of 41BX1598, or the continued use of lithic technology concomitant with metal artifacts. Colonial, as well as possible Protohistoric use, is reflected in the deposits at the site. Later, post-1800 deposits were also present. This chapter provided a general overview of the major periods associated with that potential occupation span. The following chapter provides a review of previous archaeological research associated with these temporal periods in the immediate vicinity of site 41BX1598. 



\section{Chapter 3. Previous Archaeological Investigations}

Previous archaeology in the vicinity of the project area and mission locales has revealed information pertaining to the Colonial period and later times of San Antonio. Site 41BX1598 fits nicely into the historical continuum that has been revealed in the archaeological environs of Military Plaza. Various archaeological investigations have been conducted in Military Plaza and historical downtown San Antonio over the years, including investigations directly south of the project area at the Spanish Governor's Palace. These archaeological investigations provide glimpses into San Antonio's past ranging from the early 1700s through the early 1900s.

\section{Investigations in the Immediate Area of Site 41BX1598}

Some of the earliest projects conducted in the downtown area of San Antonio were associated with Mission San Antonio de Valero (Figure 3-1, the Alamo, No. 1), located to east of the current project area. Specifically, early work by Schuetz (1966, 1973), Tunnell (1966), Greer (1967), Sorrow (1972), Fox et al. (1976), and Eaton (1980), combined with the results of more recent work by Meissner (1996) and Nickels (2000) have produced a variety of architectural, artifactual, and faunal remains, as well as information on acequias (irrigation canals) associated with the nineteenth-century use of the mission. Other large projects in the general downtown area include work at the Alamodome (Figure 3-1, No. 2; Fox et al. 1997), the Henry B. Gonzalez Convention Center Expansion (Figure 3-1, No. 3; Tennis and Cox 1998), and the Rivercenter Mall Project (Figure 3-1, No. 4; Fox and Renner 1999). These investigations have provided valuable insights into early San Antonio.

One of the earliest studies in close proximity to the current project was undertaken in 1975 by the Texas Historical Commission. Archaeologists from the Office of the State Archeologist conducted excavations associated with the installation of air conditioning ducts in the floor of San Fernando Cathedral (Fox et al. 1977), located to the southeast of 41BX1598 (Figure 3-1, No. 5). Eighteen test pits were excavated, and the work recovered a variety of artifacts, as well as animal bone, that appeared to date from the Spanish Colonial period through the early 1870s.
Chipped stone artifacts, including flakes, bifaces, and gunflints, were also present in these deposits, though ceramics, glass, and metal dominated the material recovered (D. Fox et al. 1977). In 1977, CAR conducted excavations on the northwest side of the cathedral where the original sacristy was located. While no report has been produced on this work, artifacts retrieved from the excavations represent one of the earliest non-indigenous settlements in San Antonio, dating to ca. 1720 to 1738 .

Fox (1977) reported on investigations carried out on the Spanish Governor's Palace, just south of the current project area (Figure 3-1, No. 6). This work, conducted in 1976, consisted of test units that were placed on the northern portion of the complex, just south of Commerce Street. Ceramic evidence from the test units revealed that the northern portion of the building dated to 1725. Excavations revealed that the only Spanish Colonial structures that remained intact on the site consisted of a few remnants of the front wall and two caliche floors. Excavations also revealed that the original presidio building had been disturbed by a later reinforced concrete foundation. In 1996, Fox returned to the Spanish Governor's Palace to examine the condition of the foundations of the structure and their depth. Test units were placed against the front facade of the building. Foundations of the building were encountered 40 43 inches below the level of the present ground surface (Fox 1997:16). Spanish Colonial and nineteenth-century material was encountered during these excavations, along with large quantities of animal bone and some chipped stone material.

Other archaeological investigations that occurred in vicinity of the current project area include the investigation of the Ruiz property (Figure 3-1, No. 7) south of Military Plaza (Uecker et al. 1991). The Ruiz family played a prominent role in San Antonio history. Artifacts recovered from this investigation, particularly ceramics, dated from the mid 1700 s to the early twentieth century.

Archaeological testing for the Justice Center, located southeast of the project area (Figure 3-1, No. 8) was carried out by CAR periodically between 1978 and 1987 (Fox et al. 1989). These studies documented numerous eighteenth- and nineteenth-century house sites. Materials 


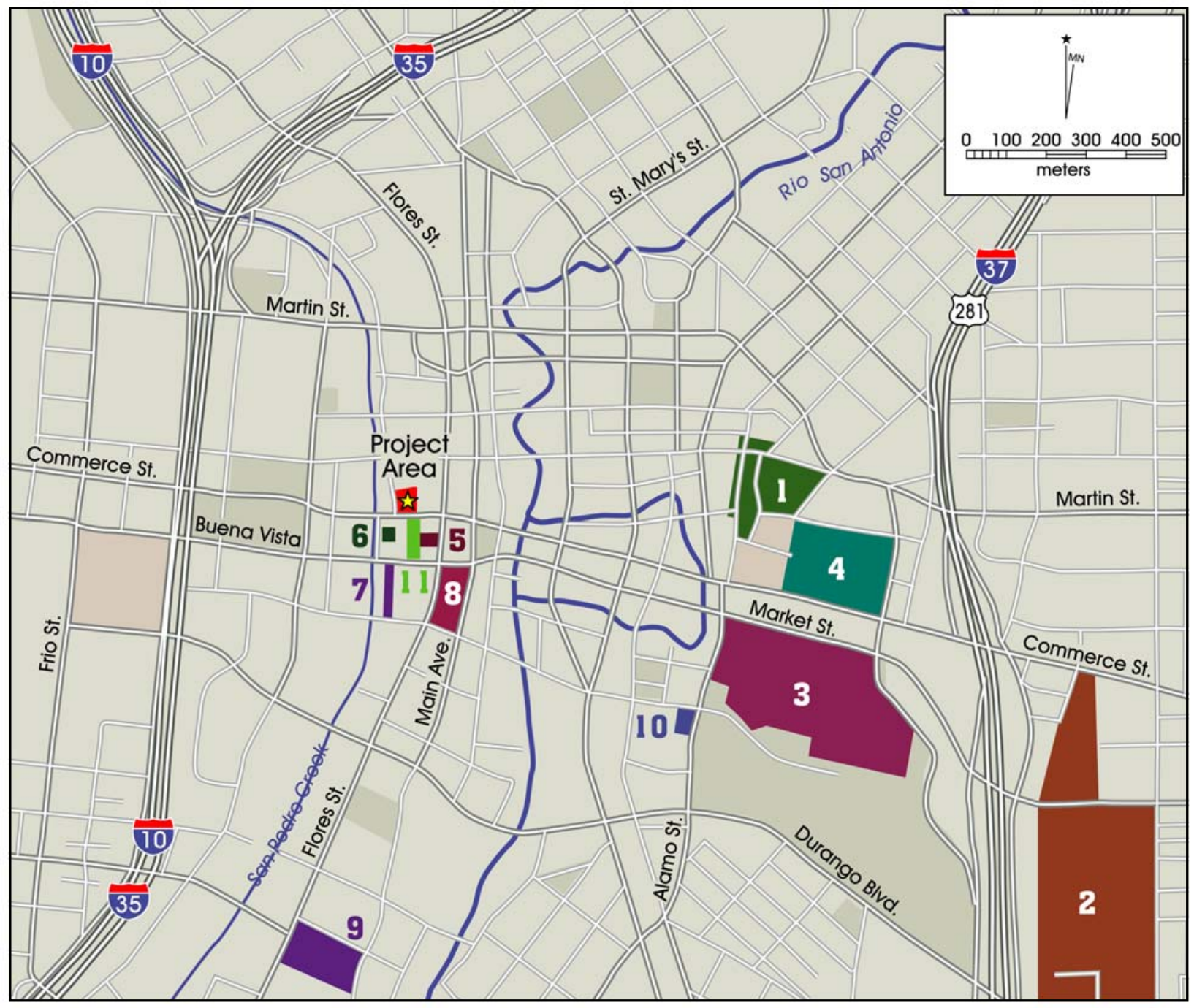

Figure 3-1. A map of downtown San Antonio showing archaeological investigations in the project area. 1. Mission San Antonio de Valero; 2. Alamodome; 3. Henry B. Gonzalez Convention Center Expansion; 4. Rivercenter Mall; 5. San Fernando Cathedral; 6. Spanish Governor's Palace; 7. Ruiz Property; 8. Justice Center; 9. San Pedro Acequia; 10. La Villita; 11. Plaza de Armas.

recovered from the Justice Center work included eighteenthand nineteenth-century ceramics, as well as metal, bone, and shell. A variety of chert artifacts were also recovered. The project also documented a portion of the route of the San Pedro Acequia (Figure 3-1, No. 9), one of many irrigation ditches that once ran through San Antonio during the Spanish Colonial period. A portion of the acequia is just east of the current project area. The acequia dates to 1719 and has been subjected to several other archaeological investigations (see Cox 1986, 1995; Nickels et al. 1996).
A variety of projects have been conducted in La Villita (Figure 3-1, No. 10), including work at 41BX677, La Villita Earthworks, in 1985 (Labadie 1986). The 1985 excavations at La Villita were concentrated in the trench fortification installed by Santa Anna's forces during the Siege of the Alamo in 1836. The materials recovered during the archaeological investigations consisted of ceramics and military paraphernalia that date between 1836 and 1850 (Labadie 1986). In addition, several features were identified and a large quantity of animal bone was recovered from that work. 
Finally, note that monitoring in the Plaza de Armas near City Hall (Figure 3-1, No. 11) was conducted by St. Mary's University (McKenzie 1995). No Spanish Colonial materials were recovered from those excavations, only latenineteenth- and twentieth-century materials were encountered (McKenzie 1995).

\section{Summary}

The archaeological investigations noted above have included eighteenth-, nineteenth-, and early-twentieth-century occupations. Combined with archival work, we know a fair amount about what happened in sections of what is now downtown San Antonio throughout much of the historic period. Nevertheless, most of these project areas, like much of 41BX1598, have been extensively disturbed by later twentieth-century buildings. Outside of selected mission contexts, we have had little opportunity to view undisturbed deposits, especially from the 1700 s and early 1800 s. When this opportunity has presented itself, the deposits have frequently been associated with specific events. It is certainly interesting to know more details about what happened at a specific location (e.g., The Alamo) during a specific time frame (e.g., 1836-1850), or to document the presence of specific artifact types or structural features at a location. This information can both add to the historical record and, in some instances, cause us to reconsider what we think we know from archival documents about a specific location or event. However, investigations into more general research themes, such as documenting changes in subsistence or shifts in specific technological systems over time, and exploring reasons for those changes, have not been at the forefront of historic research in the region. The deposits at 41BX1598, especially those from the two Colonial-period middens, are of some value in that regard as they (1) span a fairly long time frame (ca. 1700 to 1850), (2) contain moderate quantities of both artifacts and faunal remains, and (3) appear to have, in some sections, good stratigraphic integrity. As the subsequent chapter demonstrates, however, these deposits, like many in the downtown area, have been impacted by later construction. 



\section{Chapter 4: Archival Research}

According to early maps of the San Antonio area and archival research, the project area of the proposed San Fernando Community Center has a long history, beginning in the Colonial era. This chapter will review the history of the project area. Archival research included searching the Bexar County archives (Appendix D), historical maps, Sanborn insurance maps and other texts that refer to the project area and Military Plaza from the Colonial period through the early 1900s. Earliest accounts suggest that some portion of the project area may have been within the Presidio San Antonio de Béxar. In later years, the property clearly passed through several owners including early citizens of San Antonio and the San Fernando clergymen. The Sisters of Charity of the Incarnate Word obtained the property in the late 1800 s. Ultimately, the project area became a City of San Antonio parking facility.

\section{The Eighteenth Century}

Early maps of San Antonio depict the project area, located on the extreme northwest portion of Military Plaza, as possibly including portions of the Presidio San Antonio de Béxar (Figure 4-1). In 1718, Don Martín del Alarcón

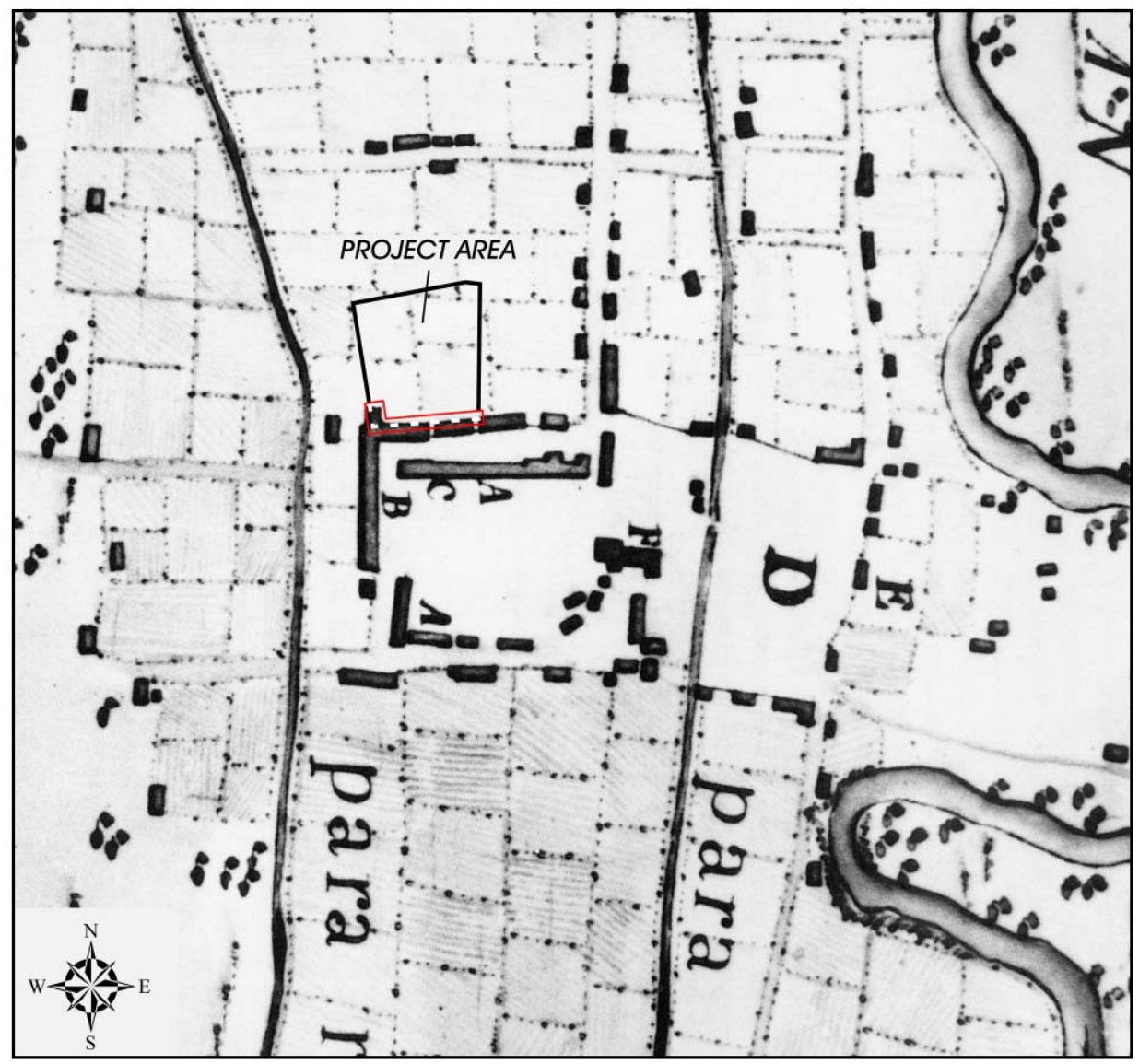

Figure 4-1. A portion of Joseph Urrutia's map of San Antonio de Bexar in 1767 showing the project area relative to (A) Casa de Presidio, (B) Casa de Captian, (C) Cuerpo de Guardia, (D) Plaza de la Villa, (E) Casas Reales, and (F) Iglesia. (Copy of map on file at CAR.) 
established the Presidio San Antonio de Béxar and Mission San Antonio de Valero near the headwaters of San Pedro Creek (Fox 1997, after Chipman 1992:14). The presidio was not only for protection, but it also served as a waystation between Mexico and the East Texas settlements.

Historical accounts suggest the presidio was destroyed by fire in the early 1700 s and a new presidio was never completed. The construction never "progressed beyond two towers, a surrounding wall and some scattered wooden or jacal structures" (Fox 1997:2, after Buckley 1911). There were 45 soldiers assigned to the presidio for the protection of an estimated total population of 200 in 1726 (see Appendix D).

According to Weber (1992:210), the presidio at San Antonio de Béxar consisted of barracks and a few other structures built around a square in the center of town. The history of the buildings northwest of Military Plaza is of particular interest since they would have been within the current project area. Early maps depict various interpretations of the layout of buildings on the northwest portion of Military Plaza. Aguayo's proposed plan for the presidio varies from other historical depictions of Military Plaza. Aguayo's original plan illustrates three rows of buildings. A 1767 map by Joseph de Urrutia depicts only two rows of buildings. The Casa de Capitan (Governor's Palace), included in the outer row of buildings, is depicted as being a continuous structure that may have extended to the southwest portion of the project area. A map by Luis Antonio Menchaca (1764) also depicts two rows of buildings and shows the outer row of buildings connected to the Casa de Capitan or Governor's Palace (Figures 4-2 and 4-3). Both historical depictions by Urrutia and Menchaca suggest only two rows of buildings as opposed to Aguayo's three rows. Urrutia and Menchaca's interpretations do coincide with historical accounts that the new presido was never completed (Buckely 1911). Therefore, the project area may border on the outer row of buildings on the northwest corner of the presidio complex.

There were a variety of individuals who resided at the Presidio San Antonio de Béxar during its existence. In 1726, Maria Josefa Flores y Valdez acquired the land. After the death of her husband Miguel Muñez Morillo, Maria married Toribio de Urrutia. In 1740, Toribio de Urrutia succeeded his father, Captain Joseph de Urrutia as captain of the presidio. The property was passed down to Maria's grandson, Manuel Nuñez, in 1807. In Menchaca's
Memoirs (1937), it is shown that Nuñez did reside on the southwest corner of the project area along with Francisco de Arocha, a Canary Islander, and José Menchaca (Figure 4-3). By 1828, the property belonged to Father Francisco Maynes who served as the associate priest at San Fernando Church (see Appendix D).

\section{The Priest's House during the Nineteenth Century}

After the property was transferred to Father Maynes, it became known as the "Priest's House" (Figure 4-4). While it is feasible that the structure known as the "Priest's House" was the same Spanish colonial building that was utilized as the presidio, the deed records and archival evidence does not convey if the structure was modified, rebuilt or remained unaltered through the years. Father Maynes remained a Mexican loyalist during the Mexican national period. The Priest's House was occupied by clergymen through the years and served as the center of municipal defense (Barr 2004). Military Plaza and the "Priest's House" played host to the first major campaign of the Texas Revolution involving Ben Milam. This event was known as the Siege of Bexar or the Battle of San Antonio de Béxar. Ben Milam and other Texans setup headquarters just north of Military Plaza at the Garza and Veramendi houses, on Soledad Street (see Appendix D). While attempting to assault General Cós's troops, Ben Milam was shot in the head by a Mexican sharpshooter. During this battle, the Priest's House was overtaken and Cós and his troops were driven out of San Antonio. One historical map notes the route taken by Milam's men. It heads west from the Veramendi and Garza houses and terminates at the Priest's House.

According to Yoakum, on the north side of Military Plaza a redoubt was erected (1855:16). A redoubt is a small, enclosed, usually well-protected temporary outpost and it is often situated to easily defend strategic positions, the entry to a particular place or a key trench line. The account by Yoakam differs from other references as it illustrates the "Priest's House" along the north side of the Main Plaza (1855: 30; Figure 4-4) as opposed to William Corner (Figure 4-5) who clearly depicts the "Priest's House" on the northern side of Mititary Plaza. The other possibility is there was more than one Priest House in the environs of the Main Plaza. 


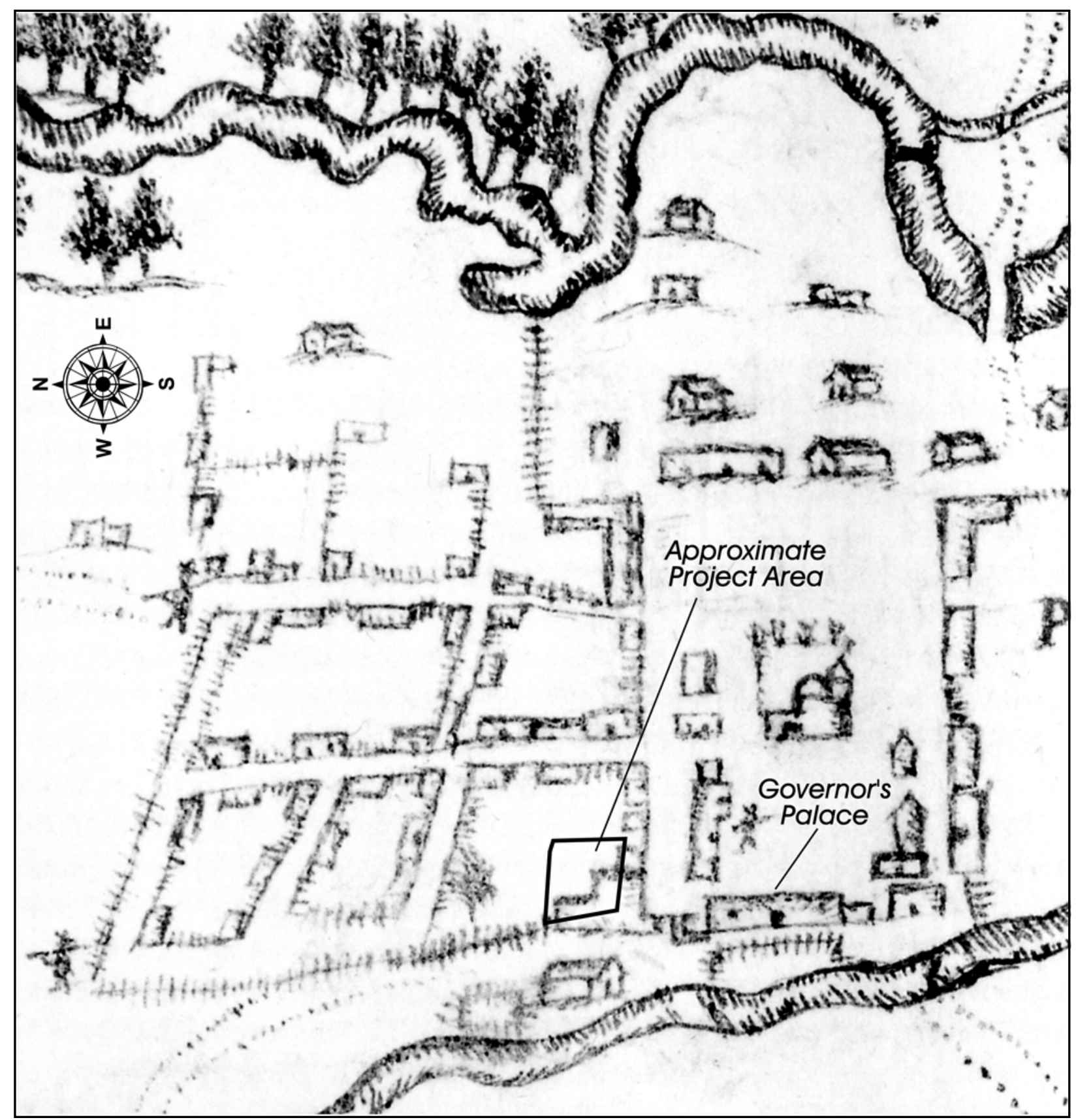

Figure 4-2. Detail of Luis Antonio Menchaca's 1764 map of San Antonio de Bexar, facing east, showing approximate area of the current project. (Copy of map on file at CAR.) 


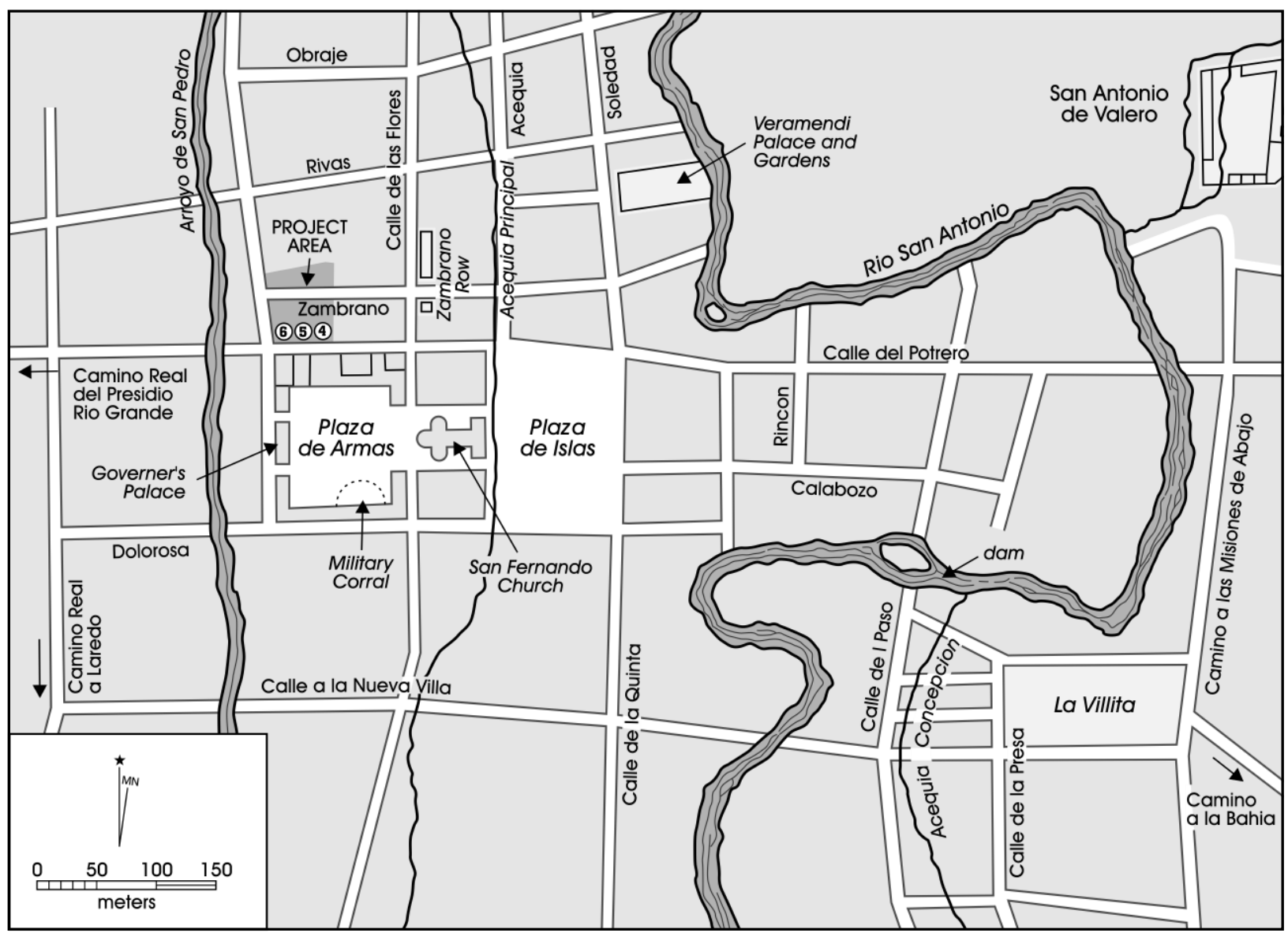

Figure 4-3. A map of the project area overlain onto an undated early map of San Antonio. Note the location of Zambrano Street bisecting the project area and the names of individuals residing on the north side of Military Plaza; (4) José Menchaca, (5) Manuel Nuñez, and (6) Francisco Arocha. (After Menchaca 1937)

A Zambrano Street is depicted on Menchaca's (1937) map and would have run through the northern portion of the project area prior to the Battle of the Alamo (see Figure 4-3). It is possible that this corridor was an alleyway and could have served as a route to attack the Priest's House. Later maps do not depict the street, suggesting it was no longer used. The street may have been named after José Dario Zambrano who served as the pastor of the San Antonio parish from 1811 to 1816 . Zambrano joined the loyalist troops that occupied San Antonio in 1813. Zambrano retired as pastor of San Antonio parish in late 1816. In 1819, Zambrano took on the responsibility of the resident priest for the Second Flying Company of San Carlos de Parras (Alamo Company).

After the Siege of Bexar, General Cós returned to Mexico with Santa Anna, setting the stage for the Battle of the Alamo and Texas's independence from Mexico. Some time after the siege, Father Maynes mortgaged the house to José Cassiano (see Appendix D). In 1840, the property was sold to John Marie Odin. Though the property transferred through several hands, it continued to serve as a home for the church clerics. 


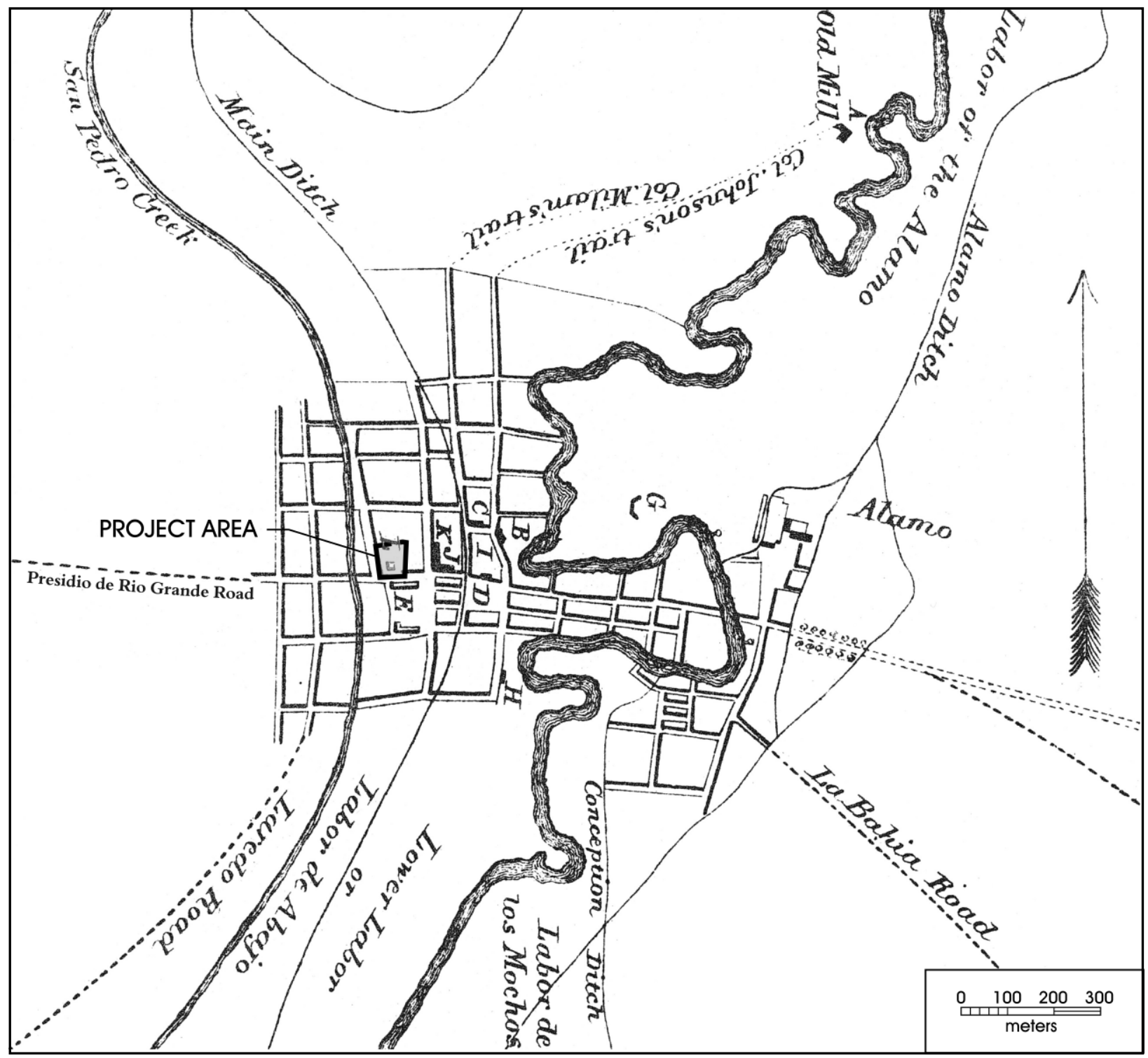

Figure 4-4. The project area shown on a map from Yoakam 1855. Note the Mexican redoubt labeled " $L$ " within the project area. 


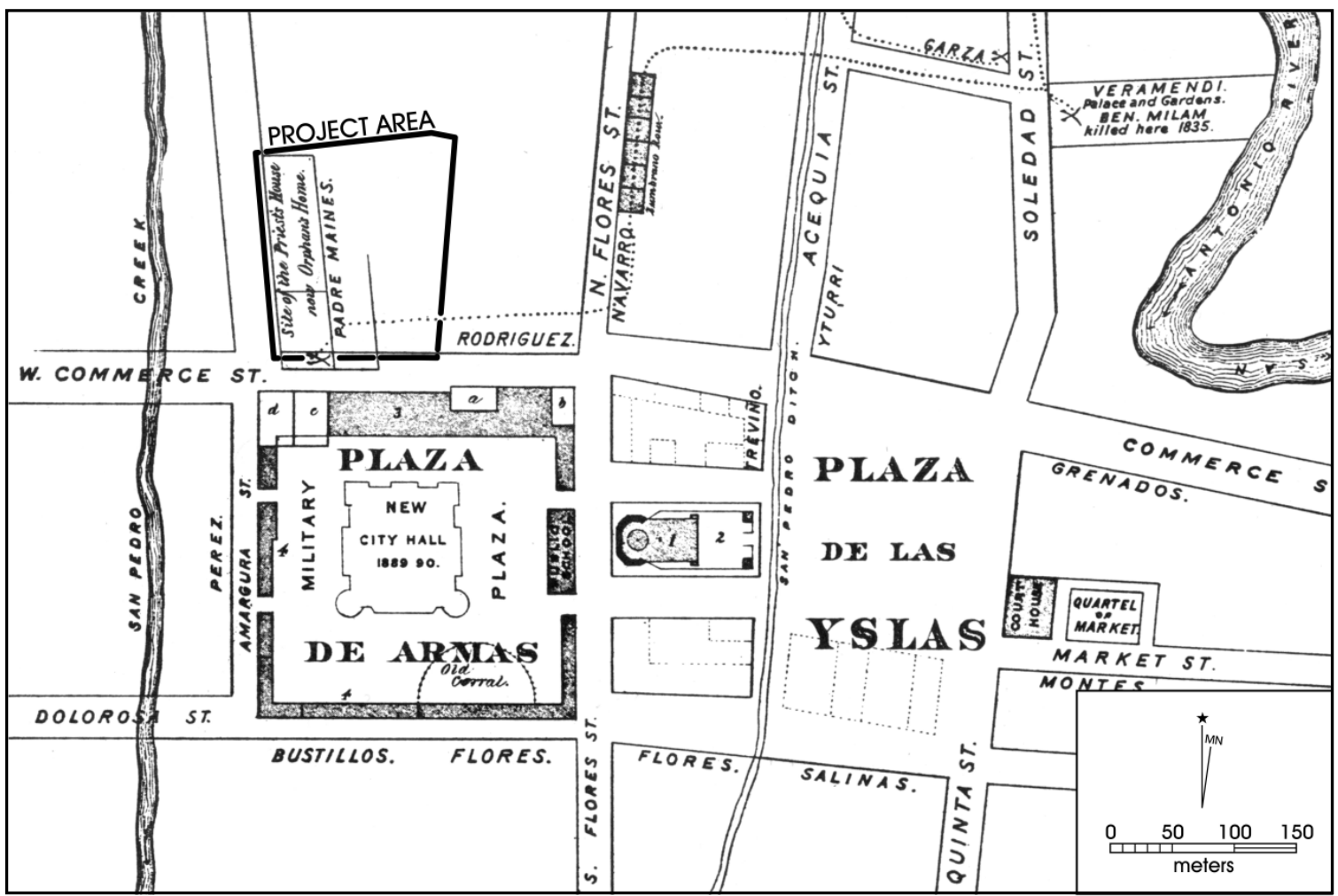

Figure 4-5. The location of the "Priest's House" along the western portion of the project area. Note that structures adjacent to the project area and within the area of Military Plaza are (3) Presidio Garrison Barracks, long since removed, (c) City Hall 1850-1890, (d) City Jail 1850-1890 (After Corner 1890).

\section{The Sisters of Charity of the Incarnate Word}

The Priest's House became the residence of bishops Claude Dubuis and John Claude Neraz. In 1869 Bishop Claude Marie Dubuis moved the Sisters of Charity of the Incarnate Word to San Antonio from Galveston, due to the wave of sickness, disease and disaster that struck the San Antonio area (Slattery 1995). Slattery (1995:1-2) states that

[t]he San Antonio River, swollen by excessive rains overflowed its banks and flooded the city, leaving many people homeless and destitute. The outbreak of typhus, typhoid fever, and dysentery that followed the rains brought new forms of suffering and health problems to the community that was still not prepared to cope with contagion and disease.
Upon arrival in San Antonio, the Sisters found that the San Fernando Cathedral Rectory, which was to serve as their convent and hospital, had burned to the ground (Slattery 1995:2). The Sisters of Charity archives indicate that the building known as the Priest's House burned to the ground before their arrival and a two-story structure was built in its place (Figure 4-6).

With the aid of the community, the two-story Santa Rosa Infirmary was opened to the public by the end of November 1869 (Figure 4-7). "Located on the corner of Camaron and Commerce Streets, the hospital, or infirmary as it was then called, was limited in its facilities to meet the needs of the growing community, yet it was respected by many as a great addition to the city"(Slattery 1995:3). In 1875, the hospital was relocated to its current location on Houston Street, and the project area became the location for St. Joseph's Orphan Asylum (Figure 4-8). It continued 


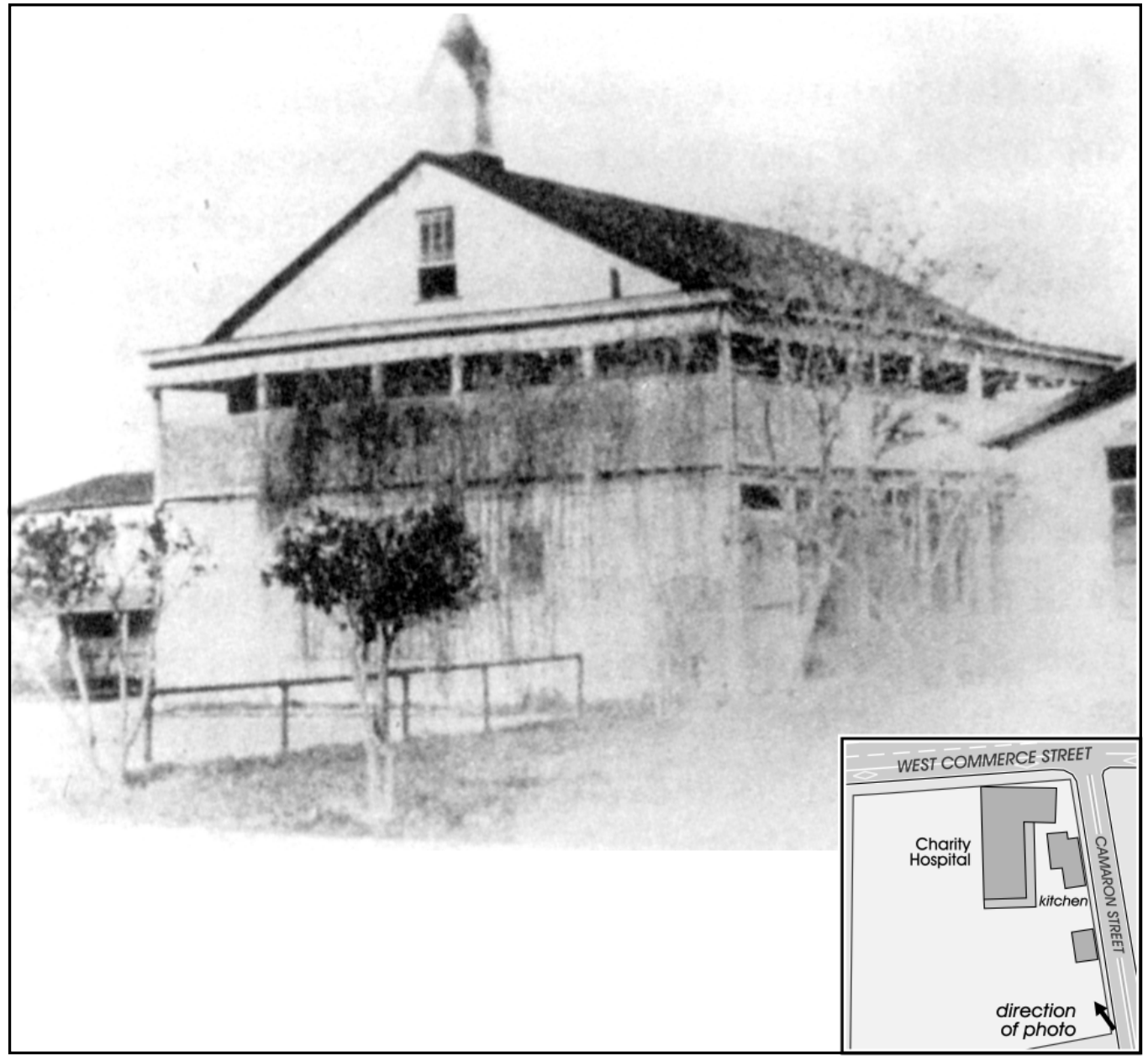

Figure 4-6. Photograph showing the rear of the Santa Rosa Infirmary constructed in 1869. The photograph is taken from the northwest corner of the property near Camaron Street looking toward the southeast. (From Slattery 1995:37)

functioning as an orphanage for girls until approximately 1911 (Figure 4-9). Thereafter, it was turned into the St. Anthony Day Nursery (Sanborn map 1951). The property was evidently sold to Hyman Investment Company in 1957. In 1961, the buildings were destroyed and the area became a city parking facility (see Appendix D).

The earliest documentation concerning the east side of the property are Sanborn insurance maps dating back to 1877 . According to the 1877 Sanborn map, a fence would have separated the orphanage from a wagon yard and grocery and dry goods store (see Figure 4-7). Wagon yards were common around Military Plaza and Main Plaza during this time period (Steinfeldt 1979). The need for a wagon yard in Military Plaza would have been necessary with the plaza being the home of various local merchants (Steinfeldt 1979).

Sanborn maps dating to 1885 depict the eastern portion of the property remaining as a wagon yard and a grocery/ hardware store (Figure 4-8). By 1911, a large imposing structure shown as a hardware store occupied the southeastern portion of the property (Figure 4-9). It is noted on the map 


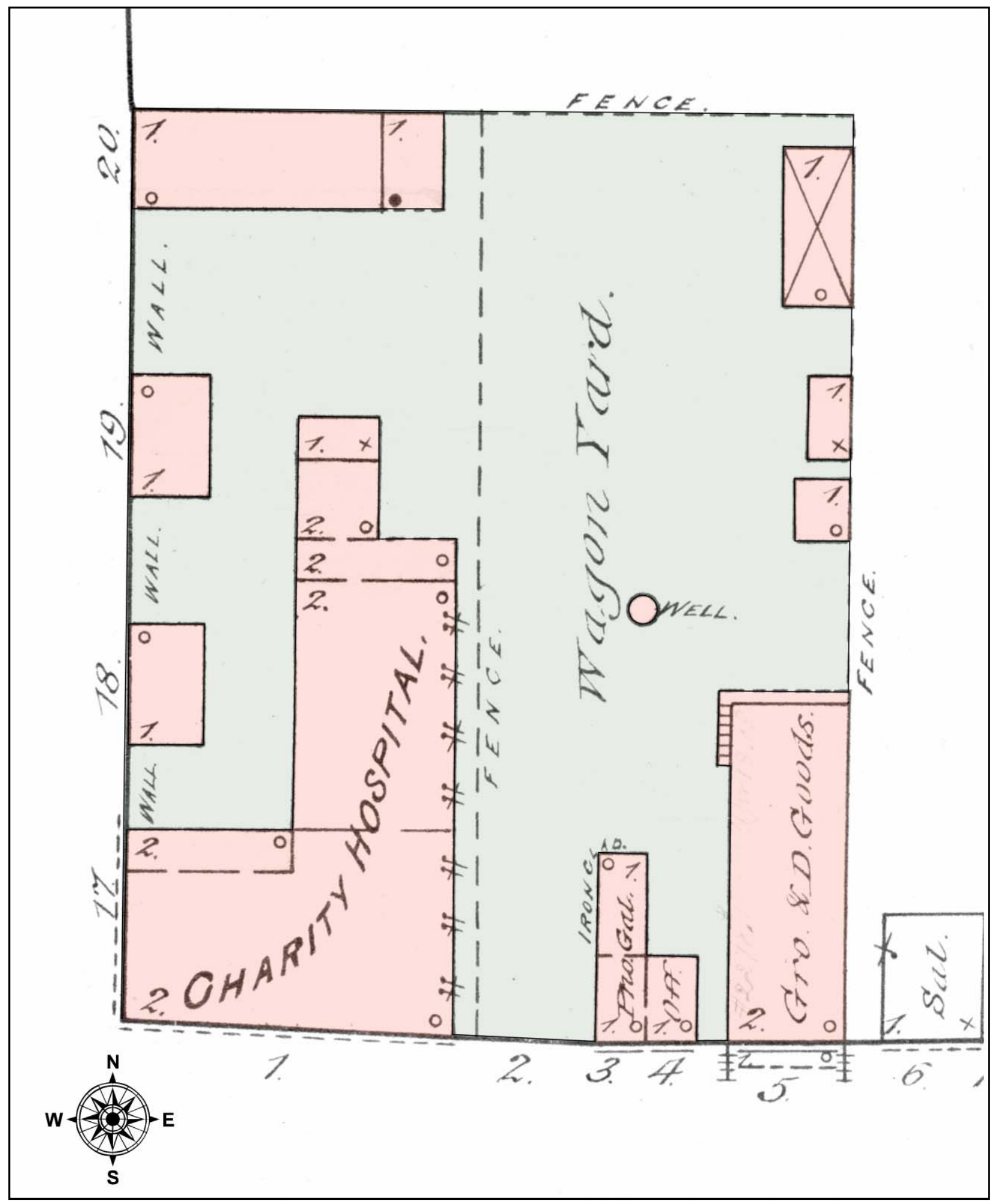

Figure 4-7. Sanborn map of the project area, dated 1877. Green shading indicates the general project area, orange shading represents standing structures and/or significant improvements. 


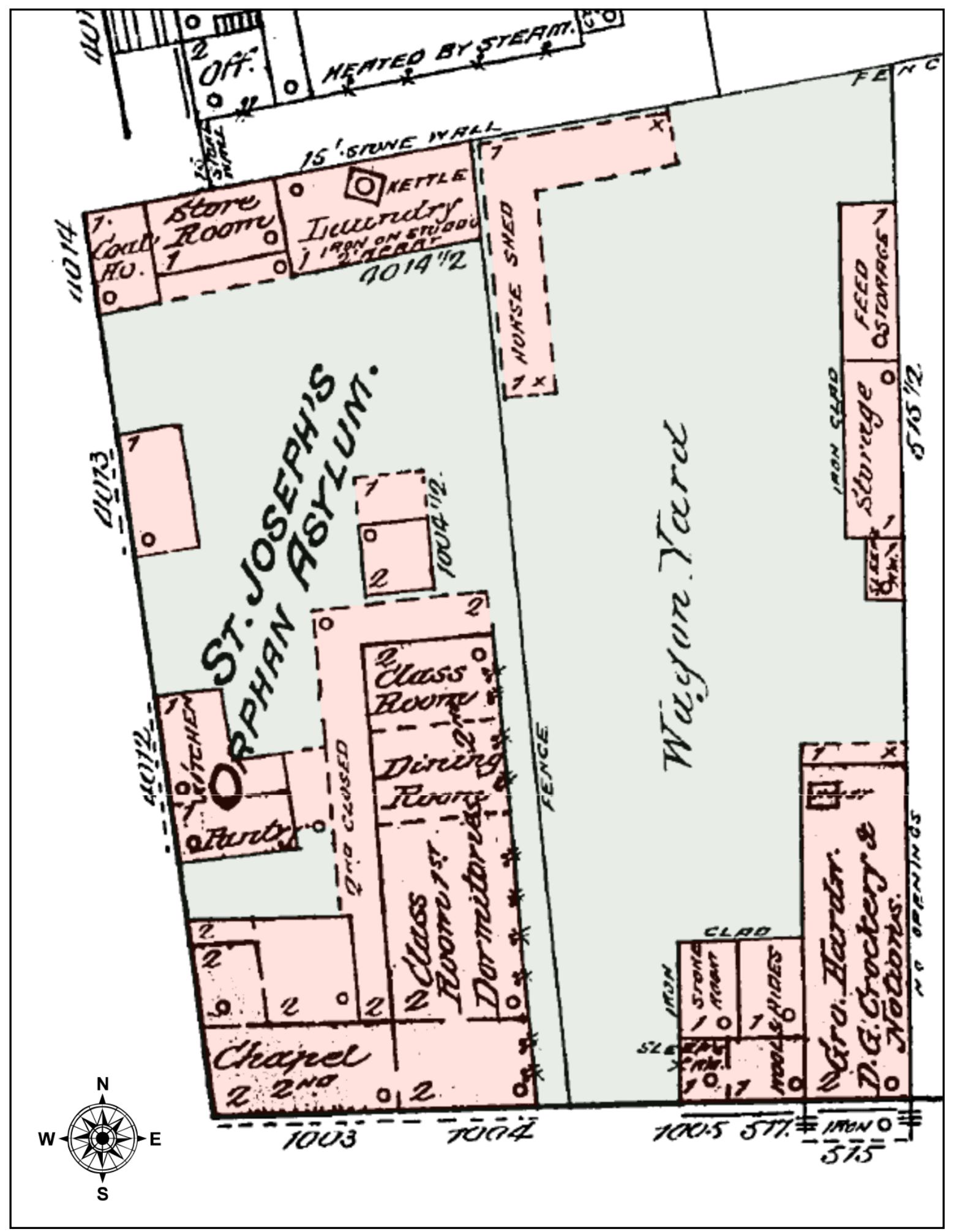

Figure 4-8. Sanborn map of the project area, dated 1885. Green shading indicates the general project area, orange shading represents standing structures and/or significant improvements. 


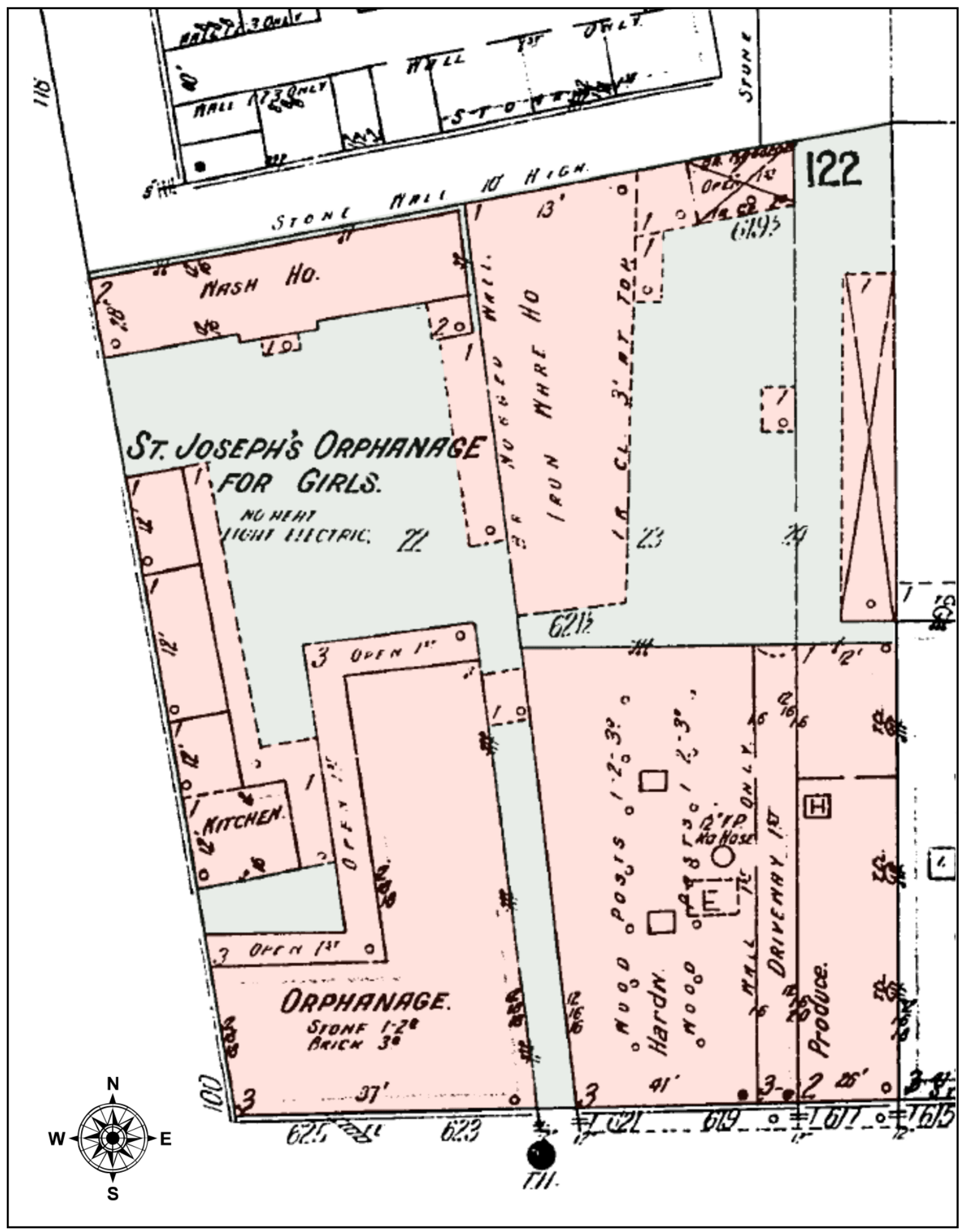

Figure 4-9. Sanborn map of the project area, dated 1911. Green shading indicates the general project area, orange shading represents standing structures and/or significant improvements. 
as a substantial three-story building with an elevator. Also, an iron warehouse is shown in the northeastern area of the property. According to the Sanborn maps, this structure did not exist on the property prior to 1885 .

\section{Summary}

The archival information presented in this chapter suggests that the project area has a long history of use, dating back to the early 1700s. The location has been associated with a variety of commercial as well as charitable ventures. The project area may encompass the area where a redoubt may have been erected during the Siege of Bexar. It is possible that the redoubt may have been in the northern portion of the project area, though it is difficult to say how long the redoubt would have stayed erected and how it would be reflected in the archaeological deposits. Given the massive construction associated with the hardware store in the southeastern portion of the project area sometime after 1885 , the potential for intact deposits in this portion of the property seems unlikely. In addition, the western section of the property also has had extensive development. Finally, the southern portion of the project, abutting West Commerce Street, has the potential to be close to the northern wall of the Presidio. 



\section{Chapter 5: Project Activities}

The archival results, discussed in the previous chapter, suggest that (1) the eastern side of the project area is unlikely to have intact deposits given the massive construction of the hardware store sometime after 1885, (2) the western edge of the property also had extensive development, but the impacts were not likely to be as deep as those on the east as the structures are less substantial, and (3) the southern portion of the project, abutting West Commerce Street, has the potential to be close to the northern wall of the Presidio, though it is unlikely that any portion of the structure is on the property. Given these results, and the presence of the midden deposit in the northwestern portion of the site, field work focused primarily on the northwestern and southwestern portions of the property.

\section{Field Activities and Methods}

As noted in Chapter 1, four different excavation strategies were used to explore the selected sections of the property. These included shovel testing, the hand excavation of test units, backhoe trenching, and mechanical scraping. These methods were used in different areas of the site to acquire specific information. To investigate the northern midden deposit, mechanical stripping, nine shovel tests, the hand excavation of four $1-\mathrm{x}-1-\mathrm{m}$ units and a single $50-\mathrm{x}-50-\mathrm{cm}$ unit, and the excavation of two backhoe trenches adjacent the vault were conducted. Backhoe trenching, in combination with mechanical stripping, was used to explore the remaining portions of the project area. One $1-\mathrm{x}-1-\mathrm{m}$ unit and one 50-x-50-cm unit were excavated in a second midden discovered at the southern end of the project area. In addition, a possible Colonial-age wall segment was uncovered in the southwestern portion of the project area. In all, about $4.54 \mathrm{~m}^{3}$ of earth was screened from the hand-excavated test units, and six backhoe trenches covering roughly $103.8 \mathrm{~m}^{2}$ were excavated.

\section{Exploration of the Northern Midden}

Our initial focus was on determining the nature and extent of the Colonial-age midden deposit, subsequently identified as Midden 1, which had been cut by the CPS vault excavation in the northern portion of the project area. The excavated CPS area was approximately 50 feet $(15.2 \mathrm{~m})$ in diameter and 21 feet $(6.4 \mathrm{~m})$ in depth. The midden was revealed in the south wall of the area excavated for the CPS vault and contained an abundance of Spanish Colonial artifacts, which included ceramics, glass, metal, burned rock, lithic debitage and faunal remains. The top of the deposits in the vault wall was roughly $1.6 \mathrm{~m}$ below the parking lot surface, and the deposits appeared to be about $40 \mathrm{~cm}$ in thickness (see Figure 1-3). It is unclear how much of the midden was destroyed by the vault excavation. In order to facilitate reaching these deposits and systematically investigating their content, careful stripping of about $90 \mathrm{~cm}$ of fill was done with a front-end loader. We stopped at this depth to be sure that we were well above the Colonial-age deposits. Figure 5-1 shows the approximate area covered by the initial removal of fill, along with three wall segments that were uncovered during that operation. The primarily north/south trending wall was composed of yellow bricks, while the shorter, east/west trending sections were composed of a mixture of larger boulders and smaller stones. These walls closely matched the locations of those shown on the 1911 Sanborn map (see Figure 4-8), and the walls were subsequently identified as being associated with St. Joseph's Orphan Asylum.

Following this initial stripping, nine shovel tests were placed on this scraped surface in an effort to establish the depth and horizontal extent of the deposits (Figure 5-2). All shovel tests were $30 \mathrm{~cm}$ in diameter and were excavated in 10 -cm levels, with all deposits screened through 1/4-inch mesh. Eight of the nine shovel tests were excavated to $70 \mathrm{~cm}$ below the scraped surface, while Shovel Test 9 was terminated at $28 \mathrm{~cm}$ when a sewer pipe was encountered. As discussed in the subsequent chapter, all shovel tests were positive and provided some information on the nature of the deposits above the midden, as well as the approximate depth of the upper midden surface in this area. However, the actual vertical and horizontal extent of the midden deposits could not be determined from the shovel test data.

Following the shovel testing, and based on those results, an additional 30 to $40 \mathrm{~cm}$ of fill was removed from the area shown in Figure 5-1. A second strategy, consisting of the excavation of two cross-cutting backhoe trenches and the initial excavation of two 1-x-1-m units, was subsequently used 


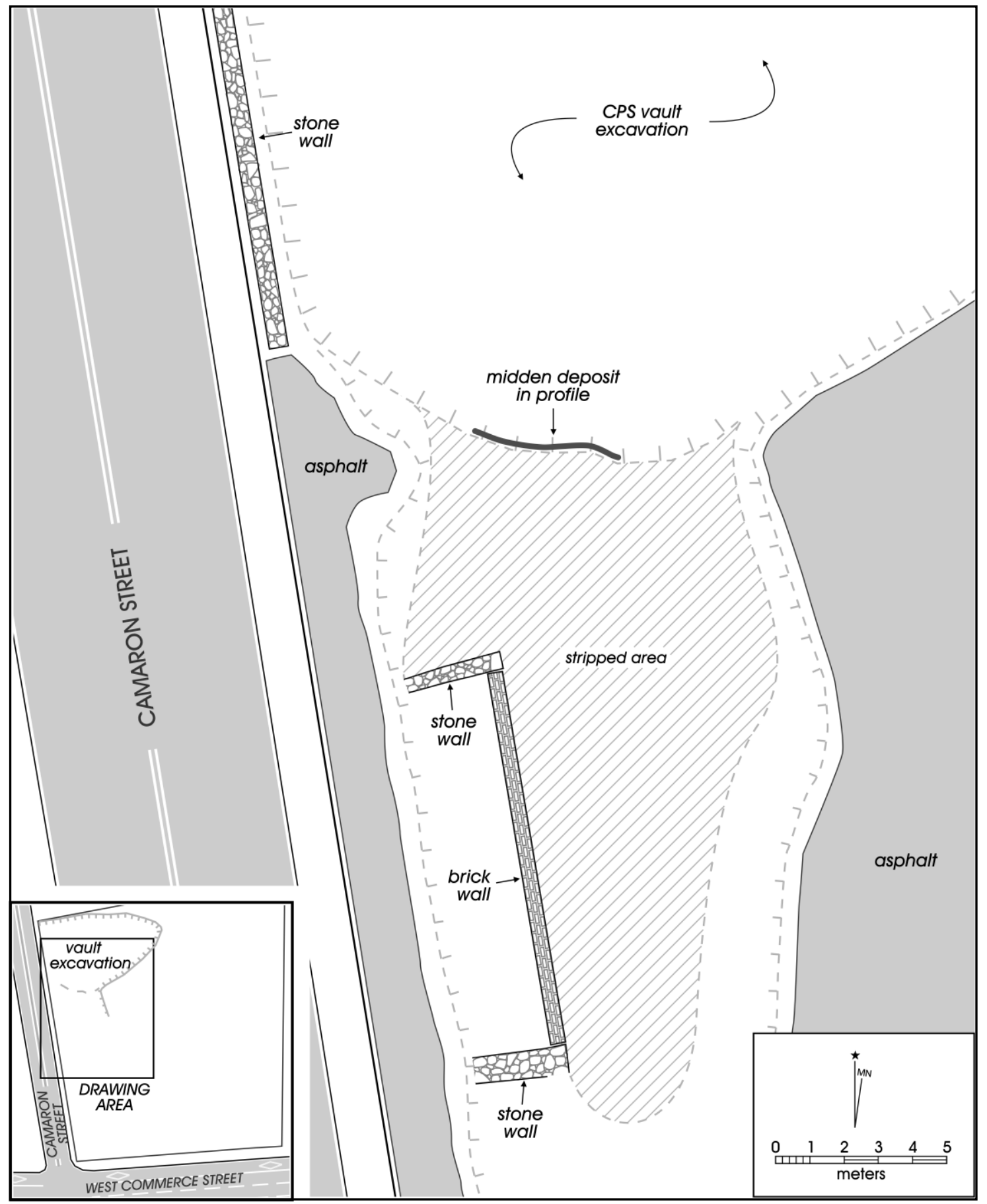

Figure 5-1. Approximate area of initial mechanical stripping at $41 B X 1598$. 


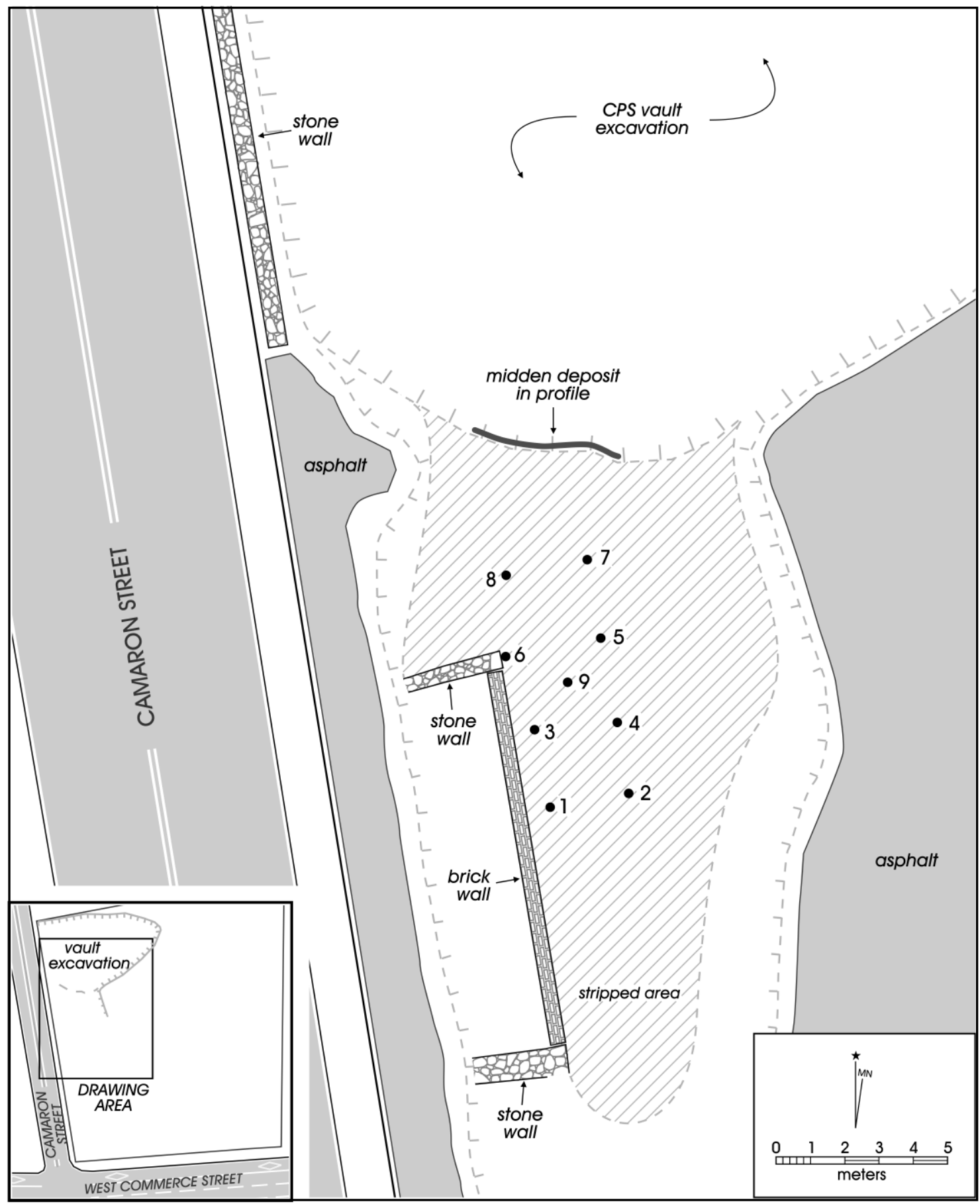

Figure 5-2. Locations of shovel tests at 41BX1598. 
in the Midden 1 area from this newly exposed surface (Figure 5-3). The trenches allowed us to establish the eastern and southern extents of the midden, and to document that the midden deposits ran under the wall associated with the orphanage (Figure 5-4). Backhoe Trench 1 (BHT 1) was roughly $8.5 \mathrm{~m}$ in length and $1.0 \mathrm{~m}$ in width, while BHT 2 was $12.4 \mathrm{~m}$ long and $1.0 \mathrm{~m}$ wide. Both trenches were excavated to a maximum depth of roughly $1.25 \mathrm{~m}$. The two test units, located to the north of the trenches, were excavated to gather information on the depth and nature of the midden deposits. Both of these units were excavated in 10-cm levels, with Unit 1 terminating at $93 \mathrm{~cm}$ and Unit 2 terminating at $84 \mathrm{~cm}$ below the scraped surface (in sterile soil). The bottoms of these units were roughly $2.2 \mathrm{~m}$ below the original pavement and roughly $20 \mathrm{~cm}$ below the bottom of the Midden 1 deposit exposed in the CPS vault excavation.

Unit 3, a 50-x-50-cm unit, was located adjacent the northern stone wall segment in order to explore the depth of that wall foundation (see Figure 5-3). This segment was originally thought to represent a Colonial-age wall based on the shape and size of the constituent stones. The unit was terminated at $40 \mathrm{~cm}$, with the base of the wall occurring at 25 to $28 \mathrm{~cm}$ below the scraped surface.

Following the excavation of BHTs 1 and 2, examination of the profiles showed the presence of several distinct depositional zones within the midden. Two additional 1-x-1-m units (designated Units 4 and 5) were excavated along the northern face of BHT 1 to sample these zones (Figure 5-4). Figure 5-5 shows the excavation of these units, as well as the associated trenches. Unit 1, located to the north, and the CPS vault area are visible in the background. Unit 4 was excavated to a depth of $128 \mathrm{~cm}$ below the scraped surface, while Unit 5 was terminated at $81 \mathrm{~cm}$ below that surface. Both units were excavated in zones, with levels within the zones not exceeding $10 \mathrm{~cm}$ in thickness.

\section{Exploration of the Remaining Portions of the Property}

Given the archival results discussed in the previous chapter, CAR investigated the central portion and eastern side of the project area using a series of backhoe trenches, while the southwestern corner of the project area was explored through backhoe trenching and the systematic removal of deposits with a front-end loader and backhoe. As shown in
Figure 5-6, four backhoe trenches, designated BHTs 3 through 6 , were excavated in the remaining sections of the property. BHT 3 was $22.61 \mathrm{~m}$ in length and roughly $1.2 \mathrm{~m}$ wide, while BHT 4 ran $26.65 \mathrm{~m}$ in length and was $1.0 \mathrm{~m}$ in width. BHT 5 was $22.7 \mathrm{~m}$ in length and $0.75 \mathrm{~m}$ in width. Finally, BHT 6 was $16.2 \mathrm{~m}$ in length and $0.75 \mathrm{~m}$ wide (Figure 5-6). All four of these trenches were excavated to a depth of $1.6 \mathrm{~m}$ below the asphalt. CAR personnel monitored the removal of fill and inspected each trench for any evidence of disturbance. While, as discussed in the subsequent chapter, a variety of pit features and wall segments were uncovered, along with pipe trenches and other disturbances, no clear evidence of pre-1850 deposits were seen in any of these trenches, with the exception of the western end of BHT 5. At that location, a second midden deposit was uncovered in the southern wall of the trench (Figure 5-7).

The second midden (designated Midden 2) was only partially preserved, having been damaged by subsequent construction activities probably associated with the orphanage. In order to investigate this second midden, CAR cleared the western edge of the feature and profiled the deposit. In this western profile, the midden seemed to be composed of at least two separate deposits, with a small, basin-shaped deposit overlain by a more recent deposit of darker soil (Figure 5-8). This upper deposit dipped to the north, and was the deposit visible in the BHT 5 profile. We subsequently excavated a $50-\mathrm{x}-50-\mathrm{cm}$ unit off of the western profile of the midden (Figure 5-7). This unit, designated Unit 6, sampled both the upper and lower components of the midden. A second unit, designated Unit 7, was subsequently excavated to the north of Unit 6 (Figure 5-7). The upper deposit was removed with a backhoe prior to the excavation of Unit 7, as the intent was to gather data from the lower component of the midden (Figure 5-8). Unit 6 was excavated to a depth of $140 \mathrm{~cm}$ below datum ( $\mathrm{cmbd}$ ), with no level exceeding $10 \mathrm{~cm}$ in thickness. In Unit 7, $57 \mathrm{~cm}$ of fill was removed in five levels, with the last level being $17 \mathrm{~cm}$ in thickness.

In addition to the backhoe trenching and excavations of Units 6 and 7, the remaining portion of this section of the property was systematically scraped using a front-end loader and backhoe. This removal was done in stages and was constantly monitored by an archaeologist. Figure 5-9 shows the initial scraping of this area, with the western wall of the Charity Hospital (see Figure 4-6) visible just 


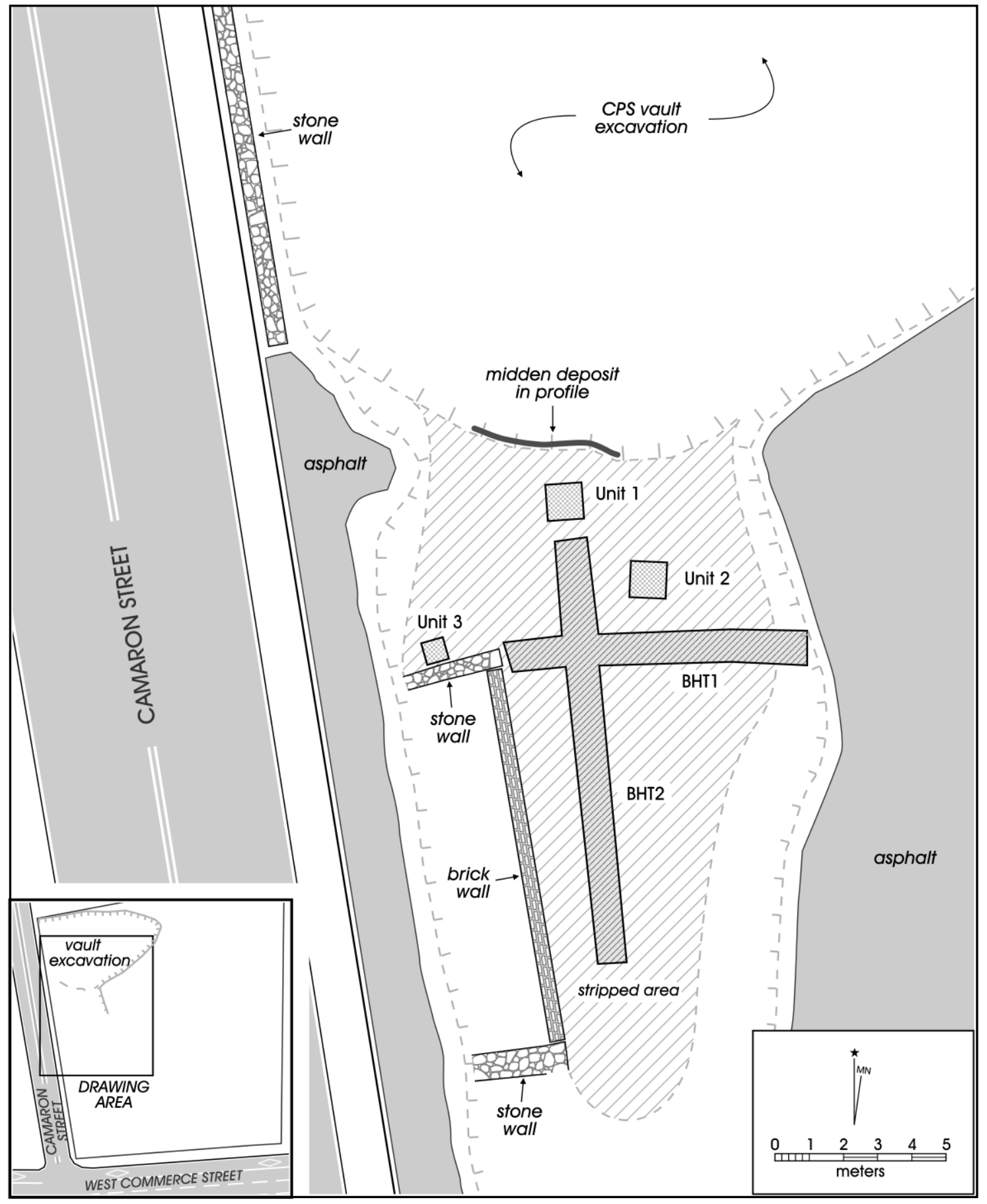

Figure 5-3. Locations of initial units and Backhoe Trenches 1 and 2 at 41 BX1598. 


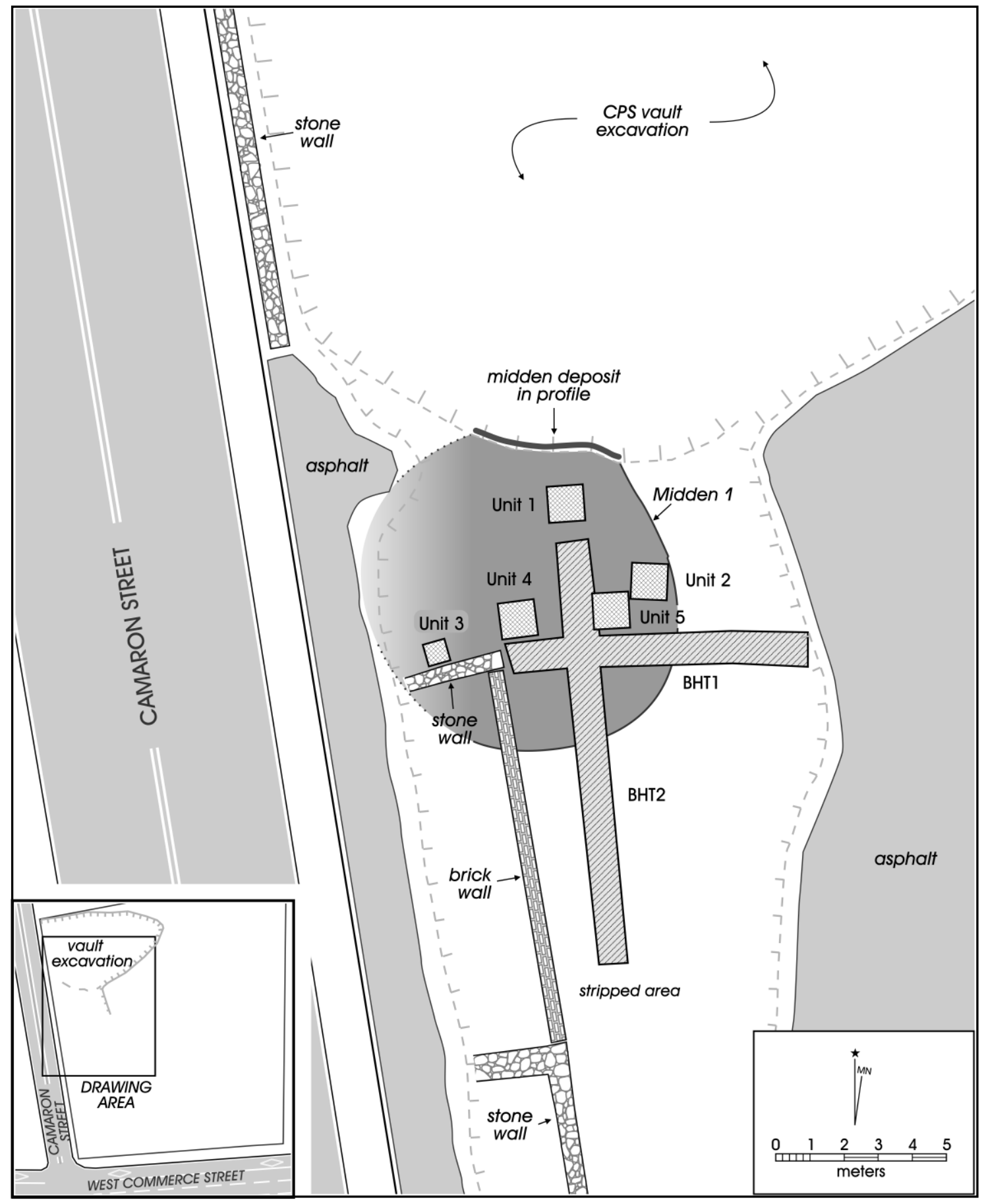

Figure 5-4. Approximate outline of Midden 1 (northern midden) at $41 B X 1598$. 


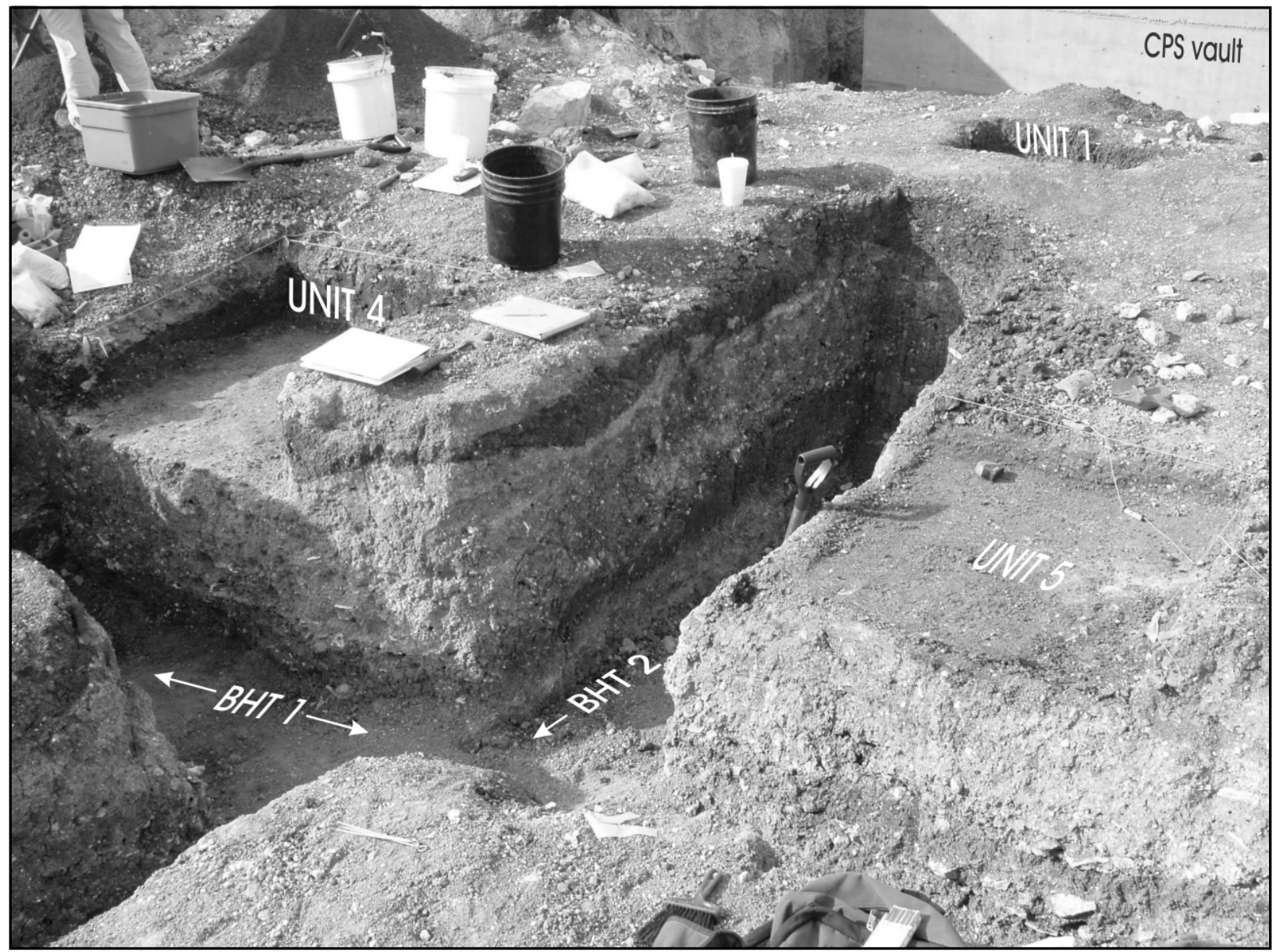

Figure 5-5. Testing in the area of Midden 1 (northern midden). Note stratification in backhoe trench walls.

to the right of the scraped area. The scraping proved effective for documenting the post- 1877 construction sequence shown on the Sanborn maps presented in the previous chapter.

Near the termination of the field work, a possible Colonialage wall segment was uncovered in the extreme southwestern portion of the property. The segment was suspected to be Colonial in age given the morphology of stone and the lack of chisel marks on the stone, a distinct characteristic of quarrying techniques employed at later times by German masons. CAR personnel photographed the wall and supervised the removal of the stones.

\section{Laboratory Activities and Methods}

All materials collected from 41BX1598 were transported to the CAR laboratory for processing. Artifacts were washed and classified into broad material types (e.g., ceramics, lithics, burned rock). All faunal material was cleaned and identified by Ms. Barbara Meissner of CAR (see Appendix A). Flotation samples collected from the Midden 1 area were processed at CAR and subsequently sent to Dr. Phil Dering, Shumla Archeobotanical Services, for analysis (Appendix B). Following the initial sorting, the content of these broad material categories (e.g., ceramics) were provided to analysts at $\mathrm{CAR}$, and classified into analytical categories. All data was then entered into Excel spreadsheets for analysis. 


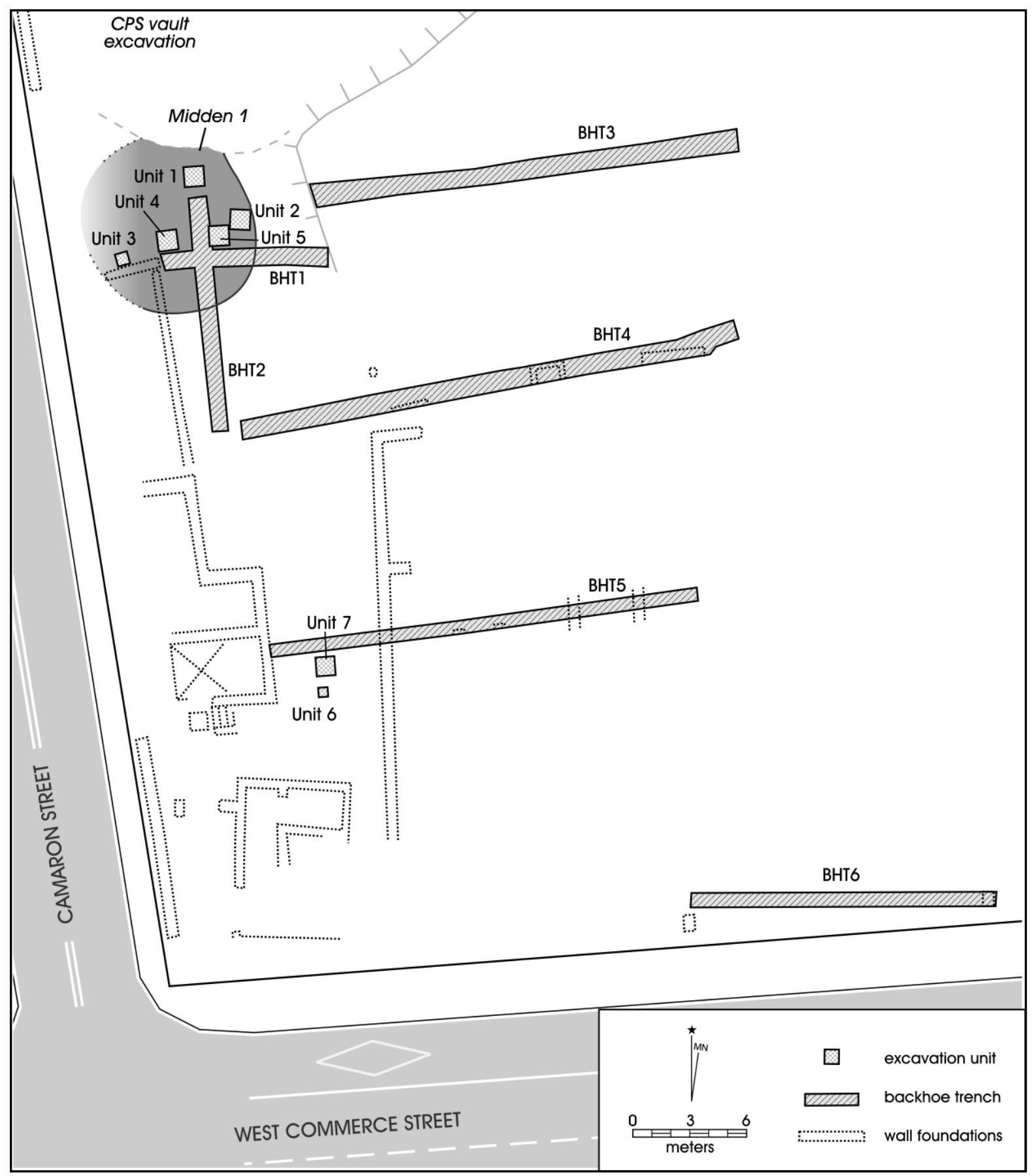

Figure 5-6. Locations of backhoe trenches and excavation units at $41 B X 1598$. 


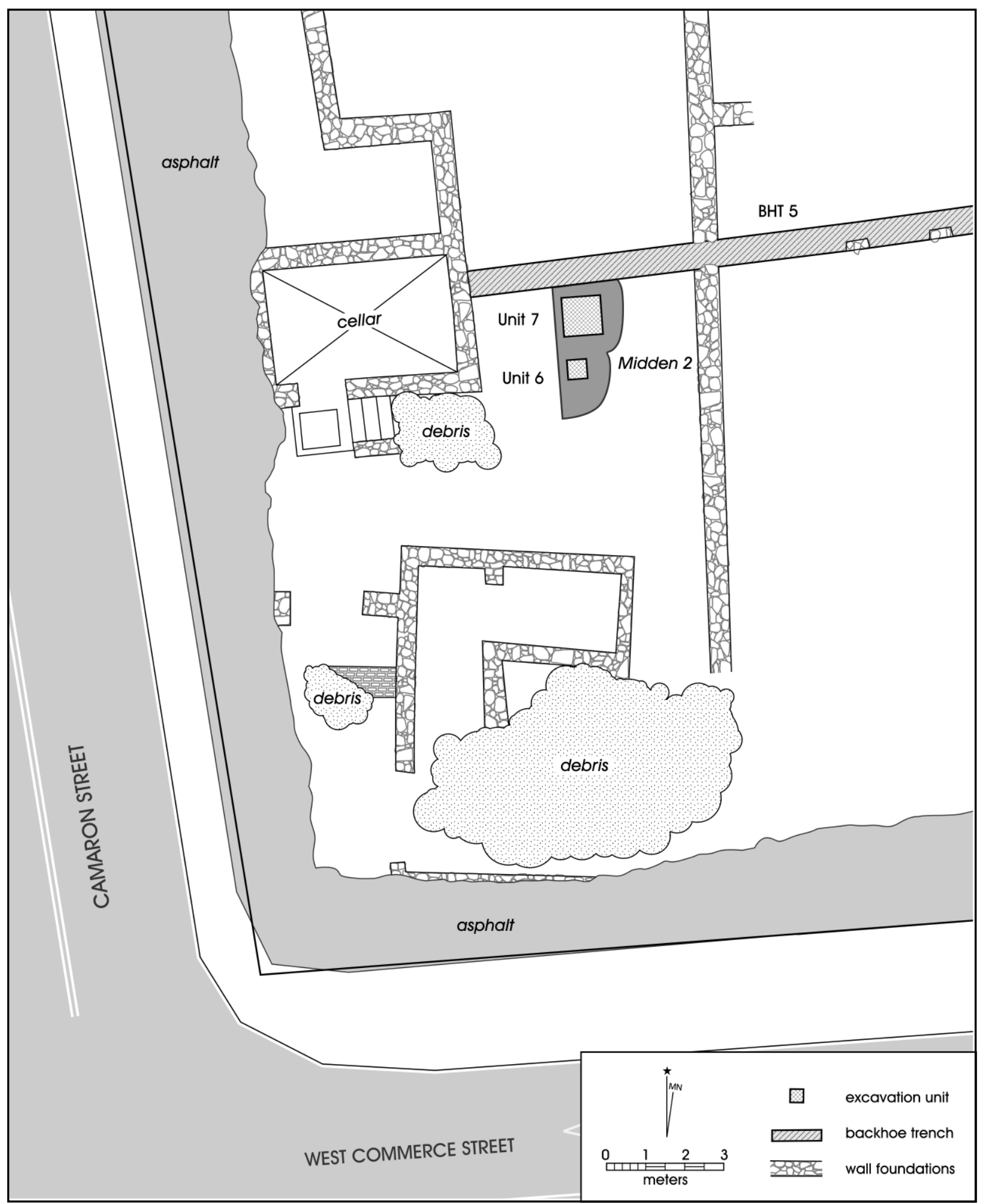

Figure 5-7. Locations of excavation units within Midden 2 (southern midden) at 41 BX1598. 


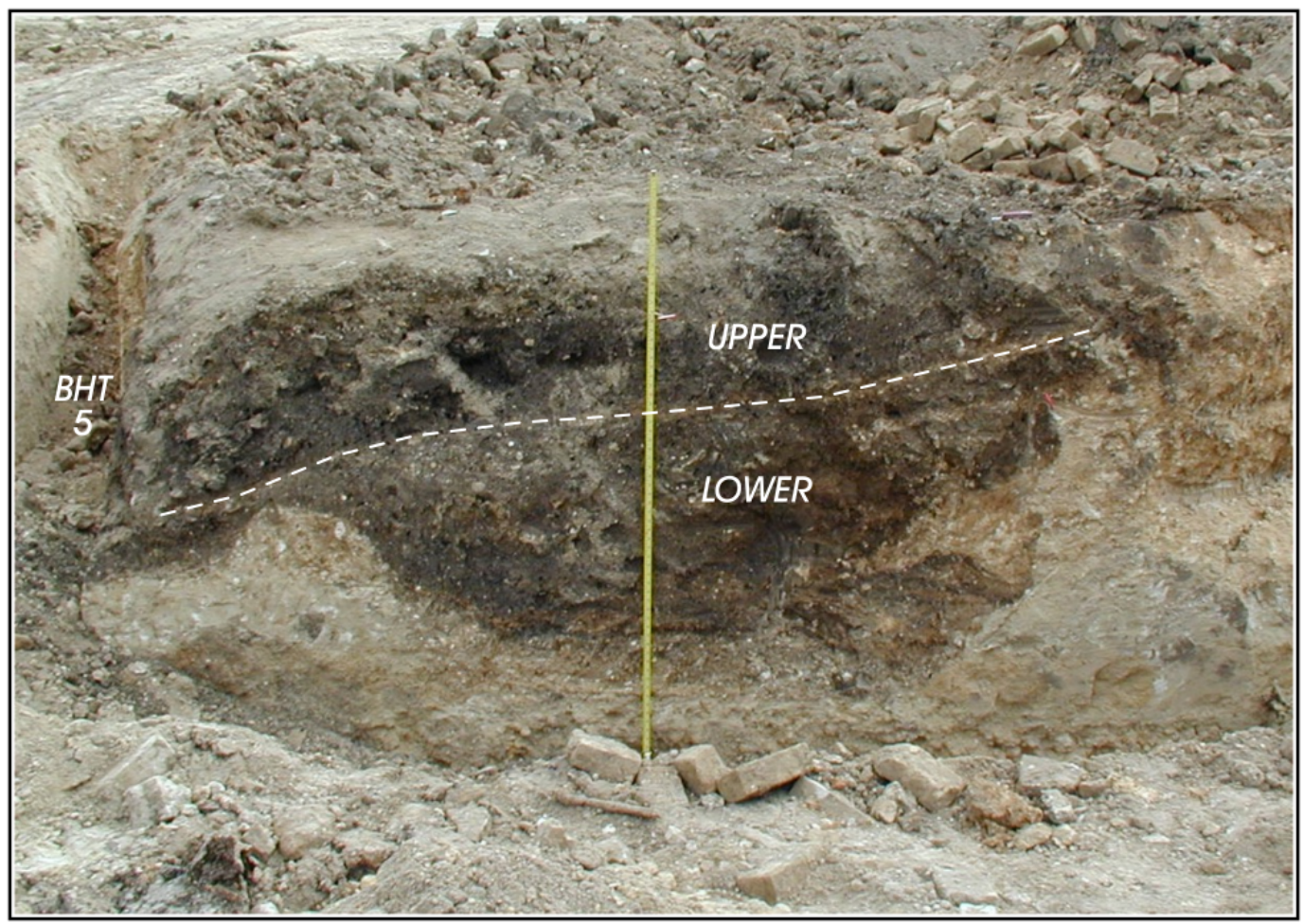

Figure 5-8. Photograph of the wall profile of Midden 2 (southern midden), looking east.

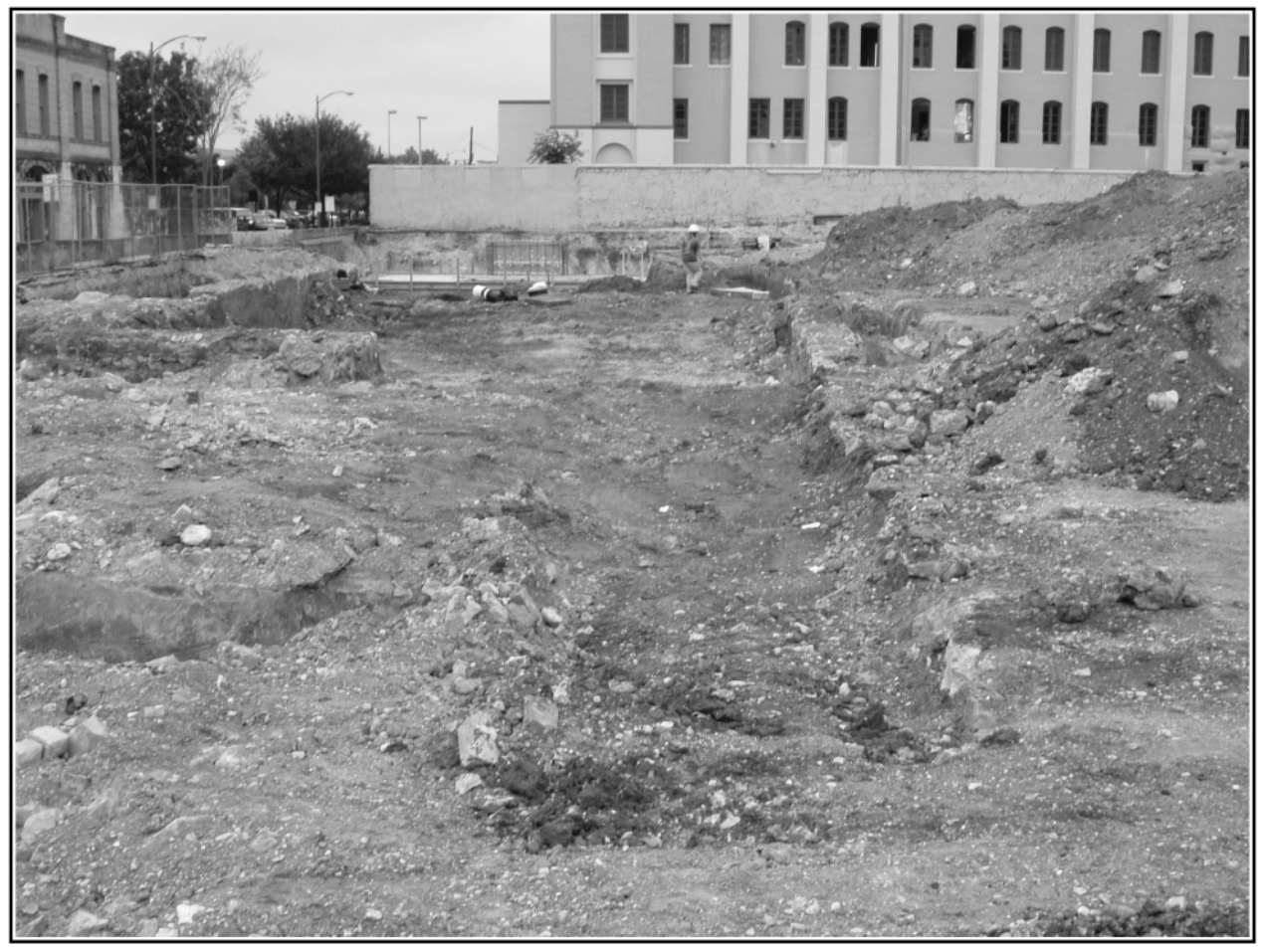

Figure 5-9. Photograph of the initial bladed area, looking north. 
Following the analysis, and in conformance with Texas Historical Commission guidelines and in agreement with the City of San Antonio Historic Preservation Office, artifacts possessing little scientific value were discarded. Discarded items included all natural gravels and pebbles, snails, burned rock, mussel shell, faunal material, and calcium carbonate nodules. In all instances, discarded materials were documented and their counts included in this report and the curation documentation. All discarded materials were disposed of following proper artifact disposal procedures. All remaining artifact materials, including all field notes, photographs, and other documents associated with the project, were prepared for curation in conformance with 36 CFR part 79, and in accordance with current CAR curation guidelines. All artifacts are stored in 4-mil ziplocking archival-quality bags. Acid-free labels were placed in all artifact bags. Each label contains provenience information and a corresponding lot number written in archival ink, pencil or laser printed. Tools and ceramics were labeled with permanent ink over a clear coat of acrylic and covered by another acrylic coat. In addition, a small sample of unmodified debitage from each lot was labeled with the appropriate provenience data. Field notes, forms, photographs, and drawings were placed in labeled archival folders. Photographs were labeled and placed in archivalquality sleeves. All field forms were completed with pencil. Any soiled forms were placed in archival-quality page protectors. Ink-jet produced maps and illustrations were also placed in archival-quality page protectors to provide against accidental smearing due to moisture. 



\section{Chapter 6: Project Results}

As discussed in Chapter 5, shovel testing, test units, backhoe trenching and overburden removal were used to investigate for cultural resources in the project area. Overall, these methods, along with selected surface collections and collections out of features, produced a wide array of artifacts and bone. Major artifact classes include roughly 1,400 ceramics, over 13,000 pieces of animal bone, 291 pieces of chipped stone debitage, 15 lithic tools, including two projectile points, 498 pieces of burned rock, over 170 pieces of metal, and 181 pieces of glass. In addition, eight features, including two middens, were documented. Finally, a variety of wall segments, including a possible Colonial-age wall, were uncovered on the property. This is the first of three chapters that provide discussions of various aspects of these results. The current chapter provides general details on the recovery of material, as well as discussion of the sediment and depositional context of that recovery, for the shovel tests, backhoe trenches, and test units. Artifacts recovered are discussed in detail in the following chapter, while Chapter 8 discusses aspects of the architecture and features, including detailed discussions of the two Colonial-age midden deposits.

\section{Shovel Testing}

As noted in the previous chapter, nine shovel tests were placed just south of the CPS vault excavation in an effort to determine the horizontal and vertical extent of the northern midden (see Figure 5-2). These shovel tests were excavated from a surface created by scraping off deposits with a front-end loader at a depth of approximately $90 \mathrm{~cm}$ below the asphalt. All shovel tests were positive. Shovel Tests (STs) 1 through 8 terminated at $70 \mathrm{~cm}$ below surface (cmbs; ca. $1.60 \mathrm{~m}$ below asphalt), while ST 9 was terminated at $30 \mathrm{cmbs}$ when a pipe was encountered. A variety of artifacts were recovered, including Spanish Colonial, English, and Native American ceramics, debitage, metal, burned rock and clay, glass, mussel shell, and animal bones. While no single material type was present in abundance, bone was by far the most common item recovered, with just under 350 pieces collected from the shovel tests (Table 6-1).

Overall, observations made during the shovel testing suggest that the upper $40 \mathrm{~cm}$ in all shovel tests were characterized by dense, dark clay deposits, and were extremely compact.
Below $40 \mathrm{~cm}$ in most shovel tests, excavators noted that the characteristics of the sediments changed, with sediments being less compact, and slightly lighter in color. Figure 6-1 presents artifact and bone data that seem to support these characterizations. Note that this figure only uses data from STs 1 though 8 , all of which were excavated to $70 \mathrm{cmbs}$ in $10-\mathrm{cm}$ levels. The top portion of the figure shows the distribution of artifacts by level, while the bottom portion of the figure shows the percentage of levels with bone present by depth. The bone data were treated as presence/absence because the large number of specimens from a single level of ST 1 (see Table 6-1) would distort the overall pattern if raw counts were used. Note that both graphs have a similar distribution, with low recovery in Level 2 (10-20 cmbs), and rapid increase in recovery in Levels 5 through 7 (40-70 cmbs). Given these data, and the observations that these lower deposits were accompanied by a change in the compactness and color of the sediment, it is probable that Levels 5 through 7 were encountering the upper portions of the northern midden. Estimated depths of these shovel tests at the bottom of Level 4 (ca. $1.30 \mathrm{~m}$ below the asphalt) are consistent with where the midden was seen in Units 1, 2, 4, and 5 (ca. 1.24 to $1.53 \mathrm{~m}$ below asphalt). Finally, reference to Figure 5-2 and Figure 5-4 in the previous chapter will show that STs 1 and 2 ultimately were outside of the midden deposits as subsequently estimated through the backhoe trenching. The lower deposits (Levels 5 through 7) from these two shovel tests averaged one artifact per 10-cm level, slightly lower than the overall average of 1.25 artifacts per level for all levels of STs 1-8. In contrast, the lower deposits from STs 3 through 8 averaged 2.2 artifacts per level. Furthermore, the lower levels in these six shovel tests (3 through 8 ) contained $57 \%$ of the artifacts recovered during shovel testing, though they only represented $32 \%$ of the volume of sediments removed during that testing. These higher densities are clearly consistent with the presence of the midden in the lower levels of STs 3 through 8.

\section{Backhoe Trenches}

As noted previously, six backhoe trenches were placed within the San Fernando Community Center project area (see Figure 5-6). BHTs 1 and 2 were excavated to define the horizontal and vertical extent of the northern midden (Midden 1) that had been exposed in the CPS vault 
Table 6-1. Materials Recovered from Shovel Tests 1-9, by Depth

\begin{tabular}{|c|c|c|c|c|c|c|c|c|}
\hline \multirow[b]{2}{*}{ Artifact Type } & \multicolumn{7}{|c|}{ Depth Below Scraped Surface } & \multirow[b]{2}{*}{ Total } \\
\hline & $0-10 \mathrm{~cm}$ & $10-20 \mathrm{~cm}$ & $20-30 \mathrm{~cm}$ & $30-40 \mathrm{~cm}$ & $40-50 \mathrm{~cm}$ & $50-60 \mathrm{~cm}$ & $60-70 \mathrm{~cm}$ & \\
\hline Native American Ceramics & & & & & 1 & & & 1 \\
\hline Spanish Colonial Ceramics & 4 & & 2 & 1 & 3 & 7 & 2 & 19 \\
\hline English Ceramics & & 1 & 1 & 1 & & 2 & 1 & 6 \\
\hline Glass & 1 & 2 & 1 & & & 3 & 2 & 9 \\
\hline Nails & & 1 & & & & 1 & 1 & 3 \\
\hline Other Metal & 1 & & & 1 & 5 & & & 7 \\
\hline Brick, Tile, Mortar & & & 1 & 2 & 1 & 2 & 1 & 7 \\
\hline Debitage & & & & 1 & 1 & & 3 & 5 \\
\hline Burned Rock/ Burned Clay & 1 & & 2 & 1 & 1 & 4 & 5 & 14 \\
\hline Mussel Shell & & & 1 & & & & & 1 \\
\hline Vertebrate Faunal Remains & 23 & 22 & $143^{*}$ & 23 & 49 & 45 & 42 & 347 \\
\hline Other & 1 & & & & & & & 1 \\
\hline Total for Levels & 31 & 26 & 151 & 30 & 61 & 64 & 57 & 420 \\
\hline
\end{tabular}

*127 from ST 1

excavation and that had been sampled by the shovel tests. BHTs 1 and 2 clearly defined the eastern and southern extents of the midden. The western edge of the midden was not identified by this method, as the midden continued under several extant walls in that direction.

Examination of the trench profiles revealed several distinct depositional zones that can be seen in Figure 6-2. Figure 6-3 presents a profile of a portion of BHT 1. The eight cultural zones, numbered 1 through 8 on the profile, were capped by modern fill and underlain by a sterile matrix, designated Zone 9. Zone 1 consisted of a dark brown clay matrix that had charcoal flecking and contained few artifacts. Zone 2 was a light-colored clay matrix that had somewhat higher sand content. This zone was associated with an increase in artifacts and bone relative to Zone 1. Sediment in Zone 3 was slightly redder in color. This clay-dominated sediment had a lower sand content relative to Zone 2, and fewer artifacts, charcoal and bone were observed. Zone 4 was a thicker layer of clay with an increase in sand relative to Zone 3. This reddish brown deposit had an increase in artifacts, bone and charcoal. Zone 5 had a high density of bone, charcoal, and burned rock. The zone also had lower clay content relative to Zone 4, and had small caliche inclusions and small gravels. Zone 6 had high clay content and was reddish brown in color. Bone, charcoal, and artifacts were at a lower density relative to Zone 5 . Zone 7 showed another increase in bone, charcoal, and artifacts. The matrix of this zone was similar to Zone 6 . Zone 8 was lighter, and had a decrease in clay content. Few pieces of charcoal were observed in Zone 8, and artifacts also appeared to be less common. Zone 9 was defined as a natural sterile zone, visible at the bottom of the trench. This zone was dramatically lighter in color, with a yellowish tint, higher frequencies of small gravels, an increase in frequency of limestone, and a higher sand content relative to any of the cultural zones. Portions of this sediment, especially near the bottom of the trench profile, appeared to represent deteriorating bedrock.

Backhoe Trenches 3 through 6 were placed on the eastern and southern sections of the property in order to document construction events in these areas and search for other Colonial-period features or deposits. All four trenches had similar stratigraphy in those sections of the trench that were not disturbed by construction events. Immediately underlying the asphalt was a gravel road base. A dark brown clay loam sediment was present down to roughly 0.90 to $1.20 \mathrm{~m}$ below the asphalt. This sediment was underlain by a yellow, gravely matrix that may represent decomposing bedrock. While, as discussed in Chapter 8, a variety of pits, as well as structure walls, were encountered during this trenching, only one feature, the second Colonialperiod midden located at the western end of BHT 5, was uncovered. 

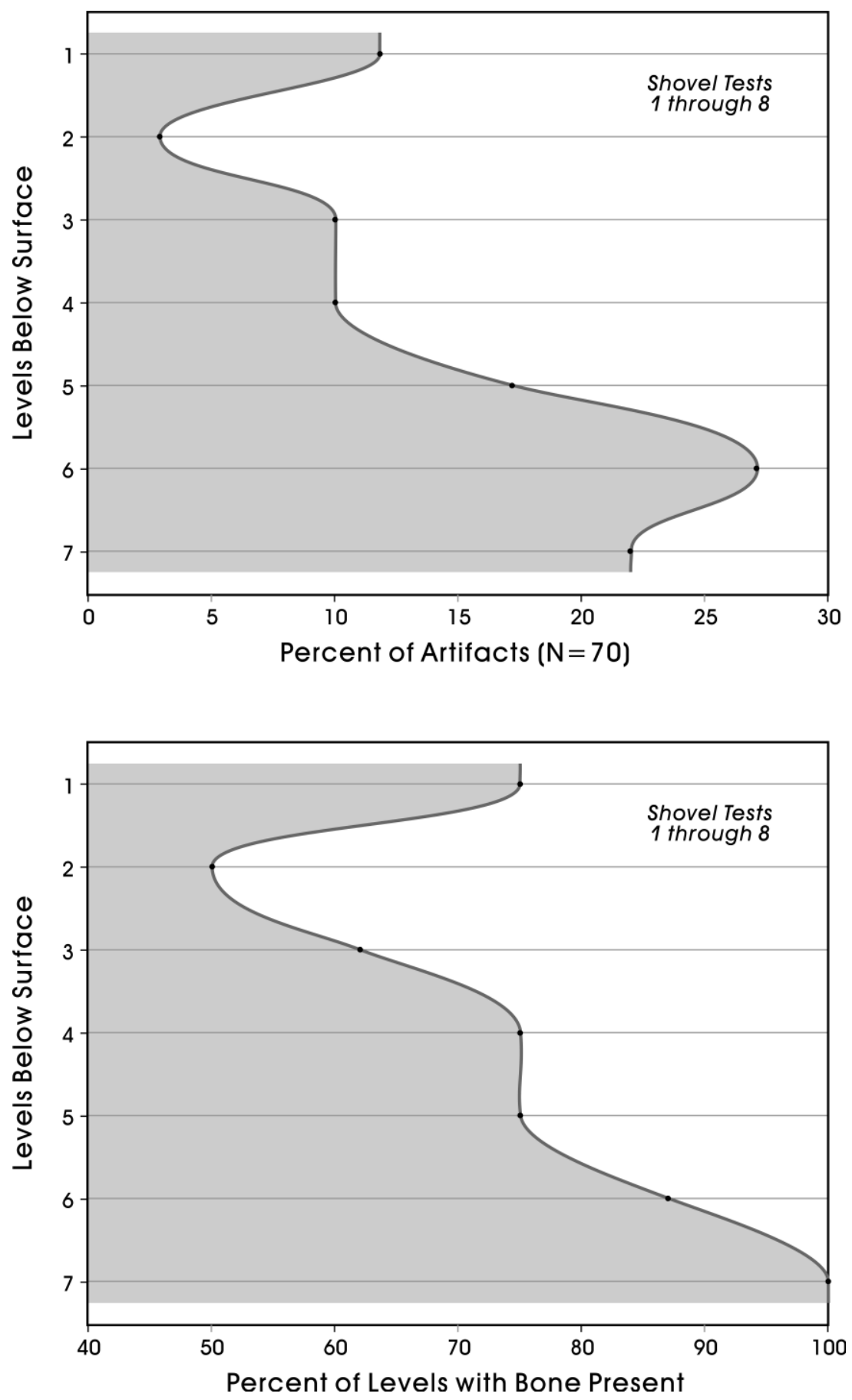

Figure 6-1. Results for Shovel Tests 1 through 8. Top is percentage of all artifacts by level. Bottom is the percentage of all levels with bone. 


\section{Test Units}

As noted in the previous chapter, five test units were excavated in Midden 1, south of the CPS vault excavation, to determine the integrity and age of this midden feature (see Figure 5-6). Units 1 and 2 were excavated in arbitrary $10-\mathrm{cm}$ increments prior to the placement of BHTs 1 and 2. Units 4 and 5 were excavated according to cultural zones, which were distinguished during inspection of BHTs 1 and 2. Level in Units 4 and 5 did not exceed $10-\mathrm{cm}$ increments. In some instances, zones were divided into more than one level. Finally, Unit $3(50-x-50-\mathrm{cm})$ was placed adjacent a wall encountered during overburden removal. A second midden feature was encountered during overburden removal in the southwest portion of the project area, in BHT 5. Units $6(50-\mathrm{x}-50-\mathrm{cm})$ and $7(1-\mathrm{x}-1-\mathrm{m})$ were excavated in this area (see Figure 5-7). They were excavated in arbitrary levels that generally did not exceed $10 \mathrm{~cm}$ in thickness.

\section{Unit 1}

Unit 1 was excavated to approximately $93 \mathrm{~cm}$ below the scraped surface from which it was dug. The scraped surface of the unit was at $1.19 \mathrm{~m}$ below asphalt, and the unit was terminated at $2.07 \mathrm{~m}$ below asphalt, with $0.88 \mathrm{~m}^{3}$ excavated. In all, nine levels were excavated in this 1-x-1$\mathrm{m}$ unit, with most being $10 \mathrm{~cm}$ in thickness. Charcoal was noted in every level, with small amounts of mussel shell present in Levels 3, 4, 6, 7, and 9.

The upper $15 \mathrm{~cm}$ (Levels 1 and 2) of Unit 1 consisted of a dark brown clay loam with calcium carbonate inclusions. It appears that these levels were disturbed. English and Spanish Colonial wares were recovered, as well as bone, lithic debitage, and burned rock (Table 6-2). At $15 \mathrm{~cm}$ below the scraped surface (Level 3, ca. $1.34 \mathrm{~m}$ below asphalt), the soil changed to light brown, loose, clay loam. Artifacts from Level 3 consisted of Spanish Colonial ceramics, English white earthenware, Native American ceramics, debitage, a lithic biface, burned rock, metal, and bone (Table 6-2). Ceramic from Levels 4 and 5 consisted of English, Spanish Colonial, and Native American wares. Other artifacts encountered were glass, bone, a bone tool, debitage, burned rock, a copper button, other unidentified metal fragments, and a paving stone. Though the soil remained the same consistency in Level 6 (1.64 to $1.74 \mathrm{~m}$ below asphalt), there was a significant increase in bone, and charcoal was

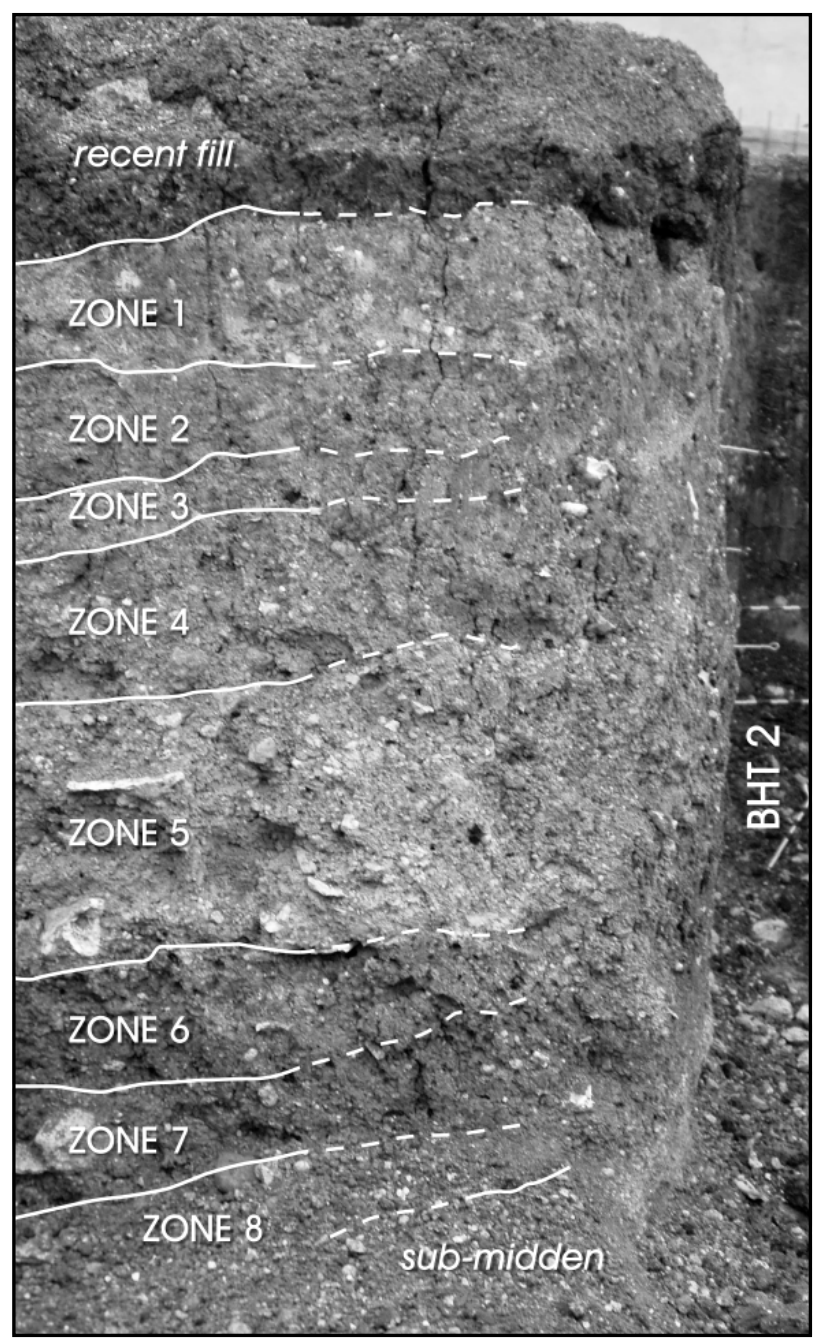

Figure 6-2. Section of Backhoe Trench 1, showing zonation visible in these deposits.

more common. Other artifacts from the level were similar to those encountered in the previous level, with the exception of one gunflint (Table 6-2). Level 7 was similar to Level 6, though there was an increase in calcium carbonate nodules. Levels 8 and 9 had a decrease in cultural material (Table 6-2). Ceramics from these depths consisted of Spanish Colonial wares, though one English edgeware sherd was recovered. The excavation was terminated at what appeared to be bedrock, roughly $2.07 \mathrm{~m}$ below the asphalt level. 
Table 6-2. Artifacts Recovered from Unit 1, 41BX1598

\begin{tabular}{|c|c|c|c|c|c|c|c|c|c|c|c|c|c|c|c|}
\hline & \multicolumn{14}{|c|}{ Artifact Type } & \\
\hline 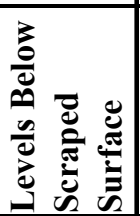 & 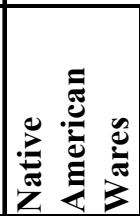 & 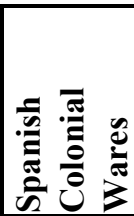 & 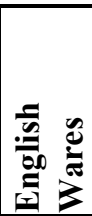 & 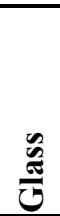 & $\sum_{\Sigma}^{\bar{\pi}}$ & 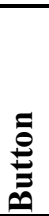 & & 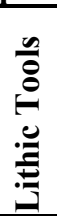 & 兽 & 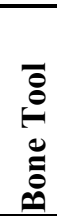 & 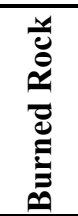 & 苞 & 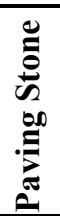 & 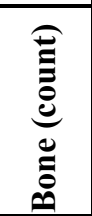 & $\stackrel{5}{0}$ \\
\hline 1 & & & & & & & 2 & & & & 5 & & & 11 & 18 \\
\hline 2 & & 2 & 2 & & & & 14 & & & & 63 & & & 46 & 127 \\
\hline 3 & 2 & 11 & 6 & & 1 & & 12 & 1 & & & 24 & & & 127 & 184 \\
\hline 4 & 2 & 18 & 12 & 8 & & 1 & 4 & & & 1 & 9 & & 1 & 214 & 270 \\
\hline 5 & & 25 & 8 & 1 & 5 & & 3 & & & & 11 & & & 190 & 243 \\
\hline 6 & 5 & 18 & 6 & 3 & & & 10 & & 1 & & 17 & & & 246 & 306 \\
\hline 7 & & 14 & 7 & & 1 & & 4 & & & & 4 & & & 181 & 211 \\
\hline 8 & & 13 & & & 1 & & 3 & & & & 1 & 1 & & 160 & 179 \\
\hline 9 & & 3 & 1 & 1 & & & & & & & 2 & & & 48 & 55 \\
\hline Total & 9 & 104 & 42 & 13 & 8 & 1 & 52 & 1 & 1 & 1 & 136 & 1 & 1 & 1223 & 1593 \\
\hline
\end{tabular}

\section{Unit 2}

Unit 2 was located southeast of Unit 1. The surface of Unit 2 was roughly $1.39 \mathrm{~m}$ below the asphalt. Eight levels, generally $10 \mathrm{~cm}$ in thickness, were excavated, and the unit was terminated at $2.12 \mathrm{~m}$ below asphalt. In all, roughly $0.73 \mathrm{~m}^{3}$ of sediment was removed from this unit. Charcoal was present throughout the unit, with small quantities of mussel shell noted in Levels 1 and 3, and burned clay noted as present in Levels 5 and 7 . The eastern wall of this unit was profiled (Figure 6-4).

Levels 1, 2, and 3 (ca. 1.39 to $1.63 \mathrm{~m}$ below asphalt) consisted of a light gray brown clay loam with an abundance of calcium carbonate inclusions. These levels were roughly equivalent, both in depth below asphalt and in sediment composition, to Levels 3 through 5 in Unit 1. Artifacts encountered in these levels were Spanish Colonial, English, and Native American ceramics, debitage, a variety of metal, including a copper coin (minted in San Antonio in 1818) and several cut nails, burned rock, bone, a lithic tool, a brick fragment, glass, and one gaming piece (Table 6-3). A higher density of bone was also present (Table 6-3). Level 4 (35 to $45 \mathrm{cmbd}$ ) contained relatively the same artifact assemblage as Levels 1 through 3 (Table 6-3) and the soil consisted of brown clay loam with calcium carbonate inclusions. Cultural material decreased in Level 5 (Table 6-3). The sediment from Levels $5(45-55 \mathrm{cmbd})$ and $6(55-65 \mathrm{cmbd})$ consisted of light sandy clay with an abundance of limestone pebbles. Ceramics recovered from these levels consisted of Native American, Spanish Colonial and English wares. Metal, lithics, glass, debitage, and burned rock were also encountered (Table 6-3). Levels 7 and 8 yielded a low density of artifacts and bone, but Spanish Colonial ceramics, debitage, and burned rock were still present (Table 6-3).

\section{Unit 3}

Unit $3(50-x-50-\mathrm{cm})$ was placed to determine the depth of a wall that was encountered during overburden removal. This unit was excavated in 10-cm increments to a depth of $40 \mathrm{~cm}$ below the scraped surface, roughly $0.95 \mathrm{~m}$ below the asphalt. Soil from the unit consisted of a dark brown clay loam. Cultural material recovered from the unit consisted of bone $(\mathrm{n}=6,3.67 \mathrm{~g})$, burned rock $(\mathrm{n}=7,34.8 \mathrm{~g})$, debitage $(\mathrm{n}=3)$, mortar $(1.5 \mathrm{~g})$, and a bone button. The base of the wall was encountered at 25 to $28 \mathrm{~cm}$ below the scraped surface, or roughly $1.2 \mathrm{~m}$ below the asphalt. 


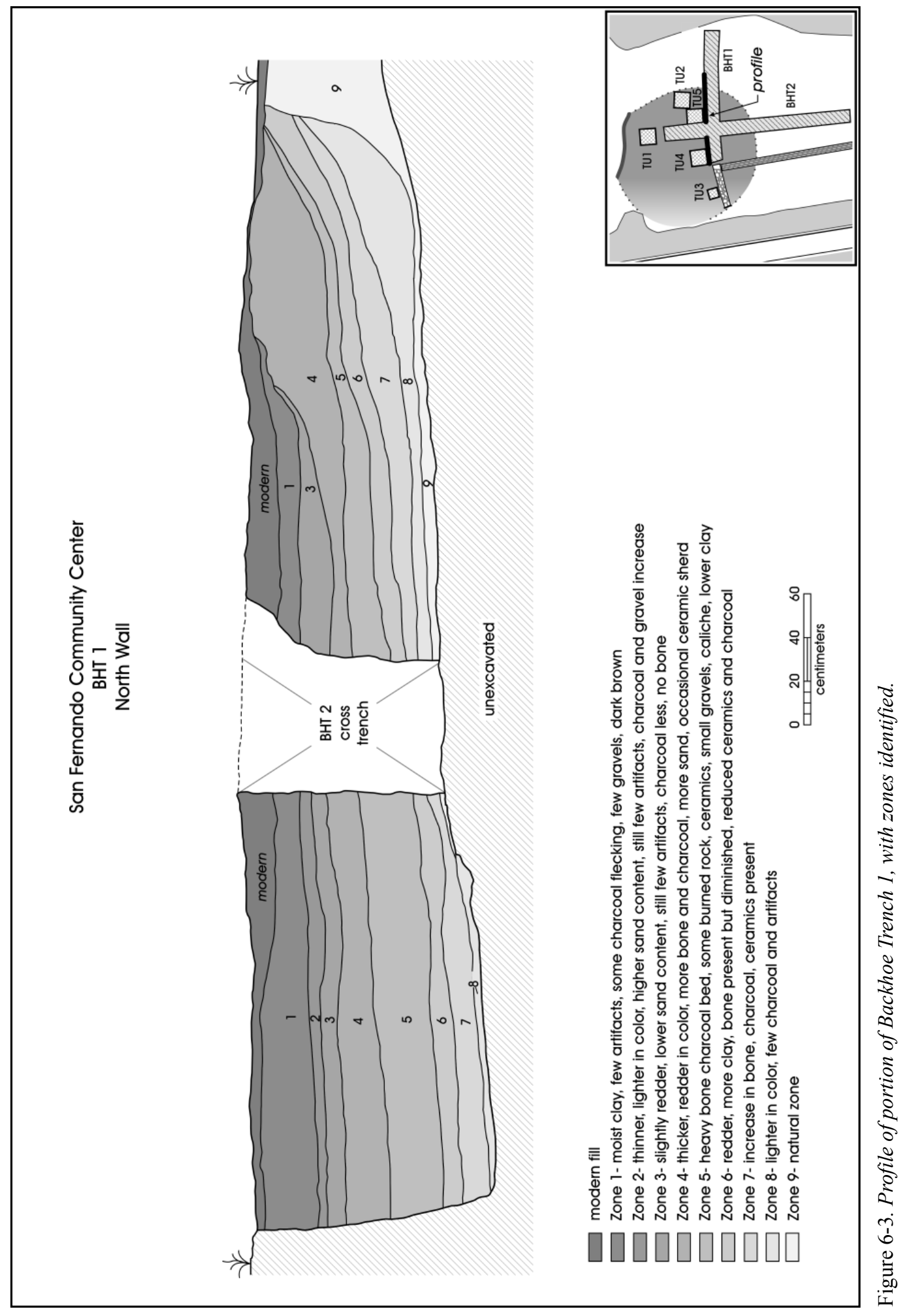


Table 6-3. Artifacts Recovered from Unit 2, 41BX1598

\begin{tabular}{|c|c|c|c|c|c|c|c|c|c|c|c|c|}
\hline & \multicolumn{11}{|c|}{ Artifact Type } & \\
\hline 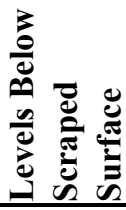 & 总 & 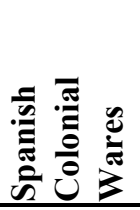 & 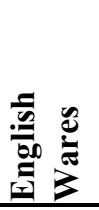 & $\begin{array}{l}\tilde{\omega} \\
\frac{\tilde{\omega}}{U}\end{array}$ & $\sum^{\bar{\pi}}$ & 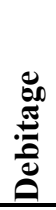 & 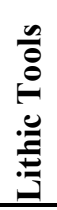 & 番 & 产 & قِّe & 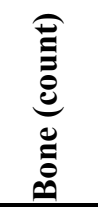 & है \\
\hline 1 & 4 & 38 & 8 & & 12 & 13 & & 1 & 30 & 1 & 502 & 609 \\
\hline 2 & 8 & 79 & 8 & 2 & 2 & 23 & 1 & & 39 & & 539 & 701 \\
\hline 3 & 10 & 31 & 4 & & 13 & 8 & & & 18 & & 351 & 435 \\
\hline 4 & 3 & 27 & 4 & 4 & 4 & 5 & & & 19 & & 320 & 386 \\
\hline 5 & 2 & 18 & 3 & 4 & 19 & 2 & & & 2 & & 208 & 258 \\
\hline 6 & & 4 & 1 & & 5 & & & & 1 & & 133 & 144 \\
\hline 7 & & 5 & & & & 1 & & & 3 & & 214 & 223 \\
\hline 8 & & & & & & 1 & & & & & 61 & 62 \\
\hline Total & 27 & 202 & 28 & 10 & 55 & 53 & 1 & 1 & 112 & 1 & 2328 & 2818 \\
\hline
\end{tabular}

\section{San Fernando Community Center \\ Test Unit 2 \\ East Wall}

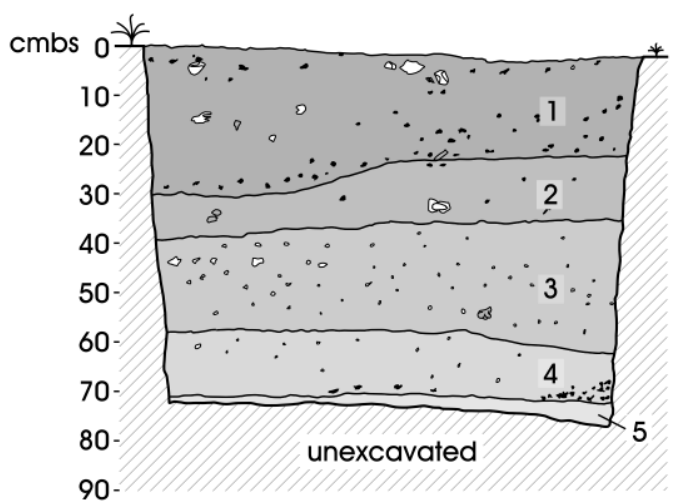

1 light gray brown clay loam

2 brown clay loam

3 sandy clay loam, reddish tan with limestone nodules, gravels and cobbles

4 sandy clay with limestone nodules, gravels and cobbles

5 weathered limestone bedrock

$\checkmark$ stone

- charcoal

$\checkmark$ bone

Figure 6-4. Profile of the east wall of Unit 2. 


\section{Unit 4}

Unit $4(1-x-1-m)$ was excavated in stratigraphic zones that were distinguished in the profile of BHT 1 (see Figure 6-3). The surface of the unit was about $1.51 \mathrm{~m}$ below the asphalt layer, and the unit was terminated at $2.74 \mathrm{~m}$ below the asphalt. Zones varied in thickness, but were commonly excavated in $10-\mathrm{cm}$ levels. In all, roughly $1.23 \mathrm{~m}^{3}$ of sediment was removed from this unit. Figure 6-5 presents a profile of the eastern wall of this unit after excavation (see also Figure 6-3). Flotation samples were taken from every zone, and charcoal was common throughout much of the excavation with the exception of Zone 8 , the bottom zone identified in this unit. Mussel shell was present in Zones 2, 4, 5, and 7, with burned clay noted in Zone 4 .

The matrix from Zone 1 (ca. 1.51 to $1.75 \mathrm{~m}$ below asphalt) was divided into two sub-zones (1a and $1 \mathrm{~b}$ ) with the upper zone consisting of a 5-6-cm-thick layer of modern topsoil. Zone $1 \mathrm{~b}$ was dark brown in color and the upper portion of this sub-zone appeared to be disturbed as fragments of sewer pipes and bricks/plaster were present (Table 6-4). Other artifacts in this sub-zone included ceramics (Spanish Colonial, Native American, and English), bone, glass, burned rock, debitage, metal, and one porcelain button. Zone 2 was roughly $6 \mathrm{~cm}$ thick, and pinched out near the north wall of the unit (see Figure 6-5). Sediment in this zone was grayish brown in color. There was an increase in cultural material, specifically in Spanish Colonial ceramics (Table 6-4). The matrix in Zone 3 (35-45 cmbd; ca. 1.81-1.91 m below asphalt) consisted of a reddish brown sandy clay loam. Artifacts from this zone included bone, burned rock, ceramics (Spanish Colonial, English, and Native American), debitage, glass, and metal. In Zone 4 (45-65 cmbd; ca. $1.91-2.11 \mathrm{~m}$ below asphalt), the sediment was a silty loam. There were pieces of charcoal and calcium carbonate inclusions scattered throughout this zone. There was an increase in artifacts, particularly in ceramics, debitage, and bone in Zone 4 (Table 6-4). The nine metal items recovered from this zone included a thimble and a cut nail. Zone 5 $(65-88 \mathrm{cmbd})$ consisted of a sandy clay loam with about $15 \%$ gravel inclusions. There was a dramatic increase in bone in this deposit, with burned rock, ceramics (Spanish Colonial, English, and Native American), debitage, lithic tools and a core, a gunflint, a bone tool, glass, and unidentified metal items also present (Table 6-4). In addition, an item identified as a gaming piece was recovered. The matrix in Zone 6 (88-98 cmbd; ca. 2.34-2.44 m below asphalt) was reddish brown. The sediment had a higher content of clay than the previous zone, but fewer gravel inclusions. There was a decrease in ceramics, bone, burned rock, and other artifacts relative to Zone 5 (Table 6-4). Two unknown ceramics were recovered from this zone. Sediment in Zone 7 (98-118 cmbd; ca. 2.44-2.64 m below asphalt) was a sandy loam with large amounts of charcoal located in small pockets. There was an increase in bone, burned rock and Spanish Colonial ceramics relative to the low totals recovered from Zone 6. Other artifacts present in this zone consisted of debitage, English and Native American ceramics, glass, and copper and iron fragments (Table 6-4). Zone 8 (118-128 cmbd; ca. 2.64-2.74 m below asphalt) had a large amount of caliche gravels. Bone decreased significantly and no other cultural material was recovered from this zone (Table 6-4).

\section{Unit 5}

Unit 5 was excavated using the same cultural zones as discussed for Unit 4. The scraped surface from which this unit was dug was roughly $1.62 \mathrm{~m}$ below the asphalt layer, and the unit was terminated at $2.34 \mathrm{~m}$ below asphalt. Roughly $0.72 \mathrm{~m}^{3}$ of sediment was removed from this $1-\mathrm{x}-1-\mathrm{m}$ unit. As with Unit 4, flotation samples were taken from each zone. Note that Zone 2, identified in Unit 4, was not present in this unit (see Figure 6-5). Charcoal was recovered from all zones, and mussel shell was present in Zones 1, 3, 4, 5, and 7. In addition, burned clay was noted in Zones 4, 5, and 6.

Zone 1 (9-22 cmbd; ca. $1.62-1.75 \mathrm{~m}$ below asphalt) contained a small number of artifacts, including brick, burned rock, one copper button, Native American, Spanish Colonial and English ceramics, debitage, glass, two bifaces, an unidentified fragment of metal, and bone (Table 6-5). In addition, an unknown porcelain ceramic was recovered. At $15 \mathrm{cmbd}$ the zone was only present in the southwestern portion of Unit 5, and Zone 3 (ca. 22-30 cmbd) was mottled with Zone 1 in the northeast portion of the unit. Recovered from Zone 3 was bone, burned rock, Native American, Spanish Colonial and English ceramics, debitage, glass, and unidentified metal (Table 6-5). A glass bead, and an unknown lead-glazed ceramic were also recovered from this zone. Zone 4 (30-40 cmbd; ca. 1.83-1.93 m below asphalt), a brown clay loam, had an increase in several artifact classes relative to Zone 3, especially bone. A bone tool was recovered, along with burned rock, Spanish Colonial, 


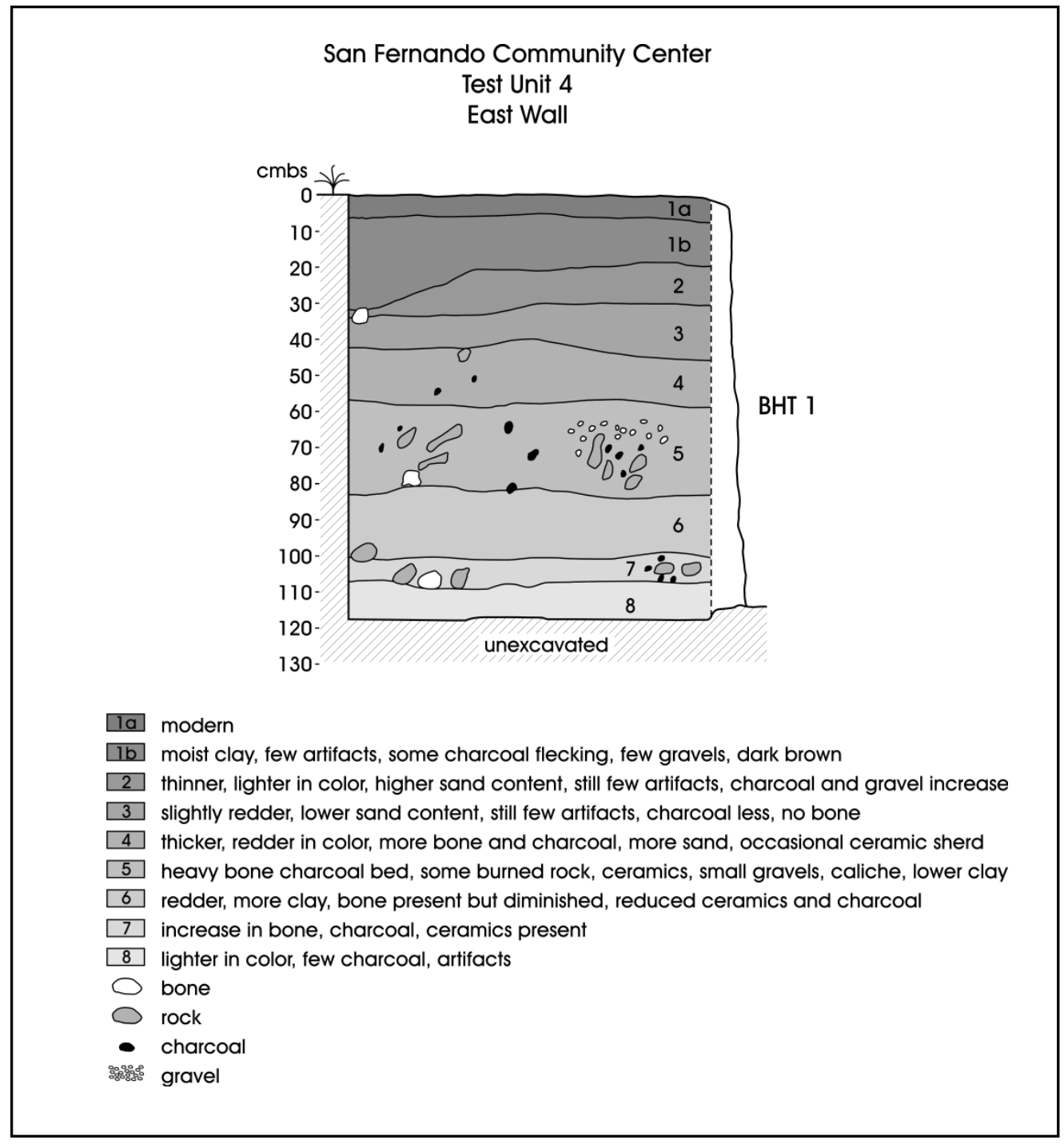

Figure 6-5. Profile of the east wall of Unit 4.

English, and Native American ceramics, chipped stone debitage, one gunflint, and one lithic tool, glass, and unidentified metal (Table 6-5). In addition, an unknown burnished brownware ceramic was recovered. Zone 5 (40$55 \mathrm{cmbd}$ ) consisted of a loose dark brown clay loam. There was an increase of gravel inclusions relative to Zone 4. In addition, there was a dramatic decrease in bone, as well as other cultural material (Table 6-5). Included in this zone were an unknown lead-glazed ceramic and a piece of Italian majolica. As in the case of Unit 4, Zone 6 (55-65 cmbd; ca. $2.08-2.18 \mathrm{~m}$ below asphalt) showed a dramatic decrease in almost all artifact classes. However, a Guerrero arrow point was recovered from this zone (Table 6-5). Zone 7 (65-73 cmbd) was a dark brown clay loam. There was an increase in bone in this zone. Other cultural material recovered consisted of burned rock, Spanish Colonial, English and Native American ceramics, glass, and unidentified metal (Table 6-5). Zone 8 (73-81 cmbd; 2.26- $2.34 \mathrm{~m}$ below asphalt) was a light brown to tan colored clay loam, with an increase in caliche nodules relative to higher zones. A dramatic decrease in all items was observed in this zone (see Table 6-5). With the exception of the 120 pieces of bone, only six other artifacts were recovered, including a single piece of cut stone. 
Table 6-4. Artifacts Recovered from Unit 4, 41BX1598

\begin{tabular}{|c|c|c|c|c|c|c|c|c|c|c|c|c|c|c|c|c|c|}
\hline & \multicolumn{16}{|c|}{ Artifact Type } & \\
\hline $\begin{array}{l}\tilde{a} \\
\stackrel{\Xi}{0}\end{array}$ & 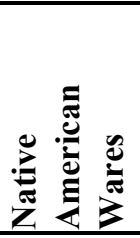 & 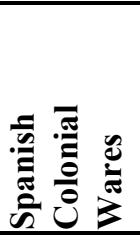 & 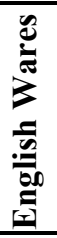 & $\frac{\omega}{\tilde{U}}$ & $\sum_{\sum}^{\bar{\pi}}$ & $\stackrel{\overline{0}}{\underline{E}}$ & 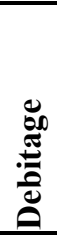 & 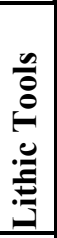 & 兽 & $\begin{array}{l}\overline{8} \\
0 \\
0 \\
0 \\
0 \\
0\end{array}$ & 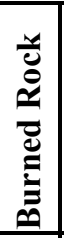 & 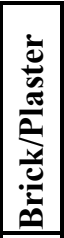 & 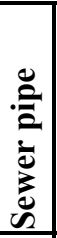 & 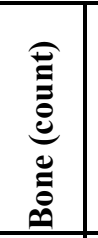 & 递 & 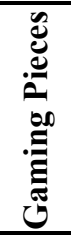 & हैّ \\
\hline 1 & 1 & 3 & 2 & 17 & 18 & 1 & 4 & & & & 17 & 1 & 6 & 128 & & & 198 \\
\hline 2 & 3 & 20 & 7 & 4 & 1 & & 4 & & & & 9 & & & 182 & & & 230 \\
\hline 3 & 5 & 10 & 4 & 1 & 2 & & 7 & & & & 3 & & & 101 & & & 133 \\
\hline 4 & 23 & 98 & 30 & 6 & 9 & 3 & 32 & & & & 10 & & & 622 & & & 833 \\
\hline 5 & 9 & 50 & 7 & 5 & 6 & & 14 & 3 & 1 & 1 & 14 & & & 1730 & & 1 & 1841 \\
\hline 6 & & 2 & & 1 & 1 & & 1 & & & & 3 & & & 94 & 2 & & 104 \\
\hline 7 & 1 & 17 & 1 & 2 & 10 & & 2 & & & & 1 & & & 1079 & & & 1113 \\
\hline 8 & & & & & & & & & & & & & & 60 & & & 60 \\
\hline Total & 42 & 200 & 51 & 36 & 47 & 4 & 64 & 3 & 1 & 1 & \begin{tabular}{|l|}
57 \\
\end{tabular} & 1 & 6 & \begin{tabular}{|l|}
3996 \\
\end{tabular} & 2 & 1 & 4512 \\
\hline
\end{tabular}

Table 6-5. Artifacts Recovered from Unit 5, 41BX1598

\begin{tabular}{|c|c|c|c|c|c|c|c|c|c|c|c|c|c|c|c|c|}
\hline & \multicolumn{15}{|c|}{ Artifact Type } & \\
\hline 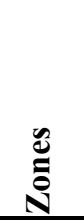 & 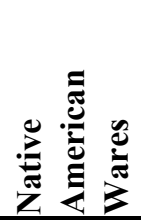 & 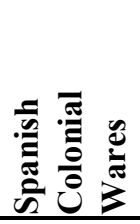 & 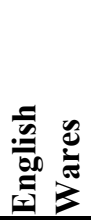 & 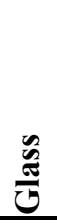 & 焉 & 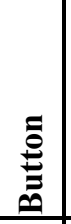 & 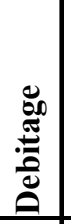 & 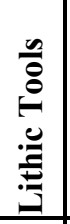 & 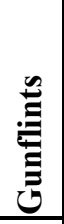 & $\begin{array}{l}\overline{8} \\
\stackrel{8}{0} \\
\stackrel{0}{0} \\
\end{array}$ & 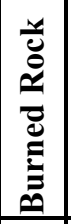 & 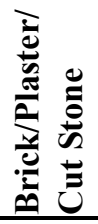 & 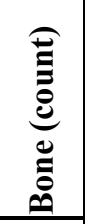 & 递 & 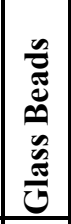 & $\stackrel{\sigma}{0}$ \\
\hline 1 & 5 & 21 & 4 & 5 & 1 & 1 & 9 & 2 & & & 10 & 1 & 166 & 1 & & 226 \\
\hline 2 & $\mathrm{n} / \mathrm{a}$ & $\mathrm{n} / \mathrm{a}$ & $\mathrm{n} / \mathrm{a}$ & $\mathrm{n} / \mathrm{a}$ & $\mathrm{n} / \mathrm{a}$ & $\mathrm{n} / \mathrm{a}$ & $\mathrm{n} / \mathrm{a}$ & $\mathrm{n} / \mathrm{a}$ & $\mathrm{n} / \mathrm{a}$ & $\mathrm{n} / \mathrm{a}$ & $\mathrm{n} / \mathrm{a}$ & $\mathrm{n} / \mathrm{a}$ & $\mathrm{n} / \mathrm{a}$ & $\mathrm{n} / \mathrm{a}$ & $\mathrm{n} / \mathrm{a}$ & $\mathrm{n} / \mathrm{a}$ \\
\hline 3 & 11 & 42 & 17 & 1 & 4 & & 10 & & & & 4 & & 173 & 1 & & 263 \\
\hline 4 & 8 & 67 & 6 & 3 & 1 & & 12 & 1 & 1 & 1 & 12 & & 806 & & 1 & 919 \\
\hline 5 & 10 & 110 & 11 & 4 & 7 & 1 & 23 & & 1 & & 17 & 1 & 184 & 1 & & 370 \\
\hline 6 & 4 & 5 & 1 & 2 & 7 & & 3 & 1 & & & 7 & & 279 & & & 309 \\
\hline 7 & 5 & 9 & 6 & 1 & 7 & & & & & & 5 & & 450 & & & 483 \\
\hline 8 & & 3 & & & & & & & & & 1 & 2 & 120 & & & 126 \\
\hline Total & 43 & 257 & 45 & 16 & 27 & 2 & 57 & 4 & 2 & 1 & 56 & 4 & 2178 & 3 & 1 & 2696 \\
\hline
\end{tabular}




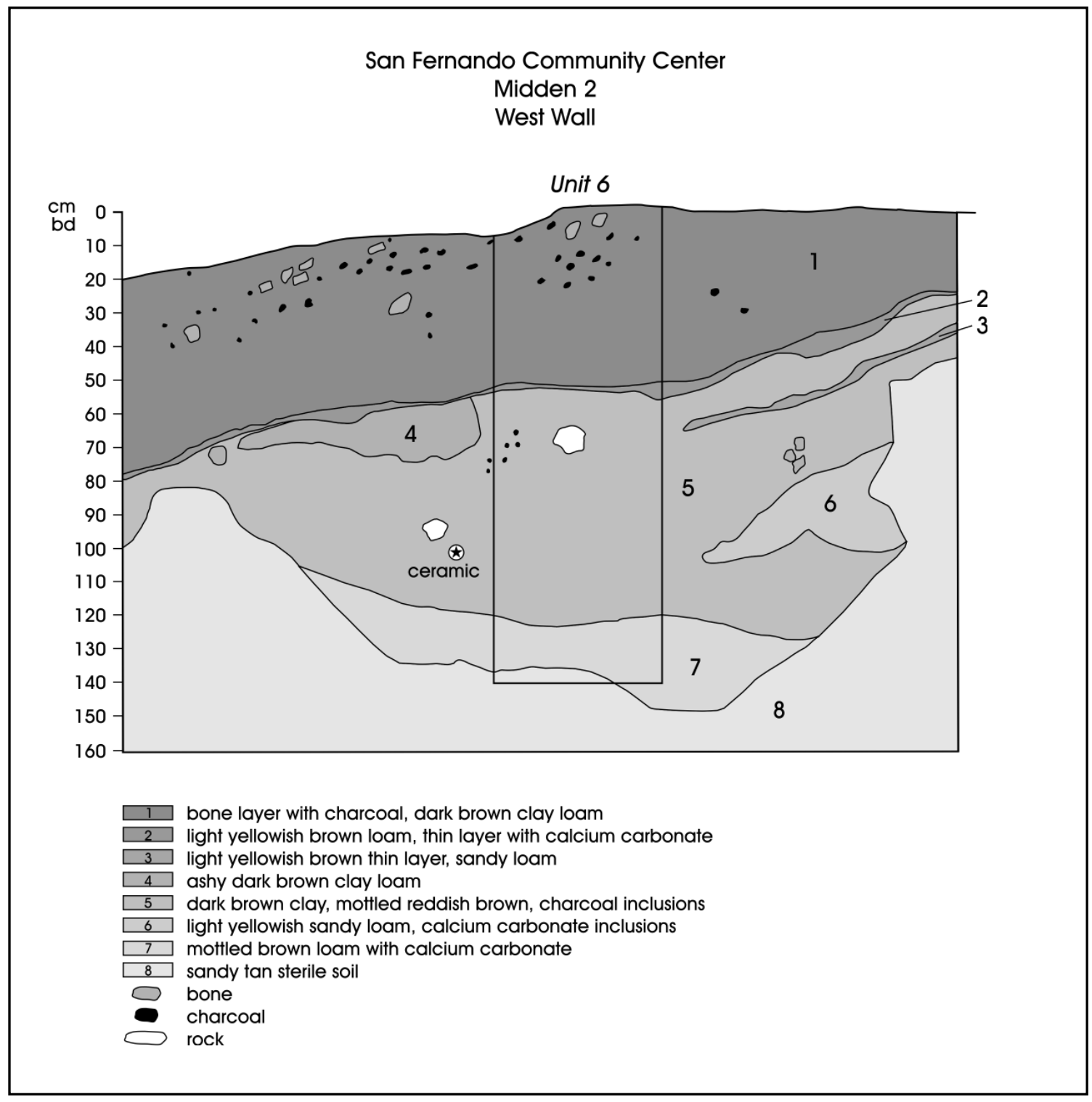

Figure 6-6. Profile drawing of west wall of Midden 2 (southern midden), with location of Unit 6 outlined.

\section{Unit 6}

Unit 6 was a $50-x-50-\mathrm{cm}$ unit that was excavated in the second midden feature encountered in the southwest portion of the project area (see Figure 5-7). The scraped surface of Unit 6 was roughly $1.51 \mathrm{~m}$ below the asphalt layer. The unit was excavated in 16 levels, none of which exceeded $10 \mathrm{~cm}$ in thickness, down to a terminal depth of $2.85 \mathrm{~m}$ below asphalt. In all, roughly $0.335 \mathrm{~m}^{3}$ of sediment was removed from this unit. Mussel shell was present in Levels 1, 2, 3,
11,12 , and 14. A small amount of charcoal was scattered throughout the unit. Based on the sediments in the midden, as well as the pattern of artifacts, two different major deposits were present in Midden 2 (Figure 6-6). The upper deposit terminated at about $56 \mathrm{cmbd}$ (ca. $2.04 \mathrm{~m}$ below asphalt) in this unit, and was separated from the lower deposit by roughly $7 \mathrm{~cm}$ of yellow caliche. The lower deposit began at roughly $62 \mathrm{cmbd}$, and terminated at around $130 \mathrm{cmbd}$ (ca. $2.78 \mathrm{~m}$ below asphalt). 
Sediment in Level 1 (3-10 cmbd; $1.51-1.58 \mathrm{~m}$ below asphalt) consisted of a brown clay loam with charcoal and limestone inclusions $(<10 \%)$. This level contained bone, one bone button, burned rock, Spanish Colonial wares, debitage, an English ceramic, and metal (Table 6-6). Level 2 (10-20 cmbd) sediment consisted of a loose clay loam. Cultural material recovered from Level 2 consisted of bone, Spanish Colonial wares, one sherd of Chinese porcelain, glass, metal, and debitage. Level 3 (20-30 cmbd; $1.68-1.78 \mathrm{~m}$ below asphalt) was a loose brown loam with bone, burned rock, unidentified metal, and English and Colonial wares (Table 6-6). Sediment in Level 4 (30-40 cmbd; 1.78-1.88 m below asphalt) consisted of a loose brown loam. Cultural material recovered from this level included bone, burned rock, debitage, glass, and Spanish Colonial ceramics (Table 6-6). In Level 5 (40-50 cmbd) the sediments were similar to Level 4. Artifacts included Spanish Colonial, Native American and English ceramics, debitage, a lithic tool, burned rock, and bone (Table 6-6). One brick fragment was also recovered from this level. Though the fragment is fairly small, the coloring denotes it may be of Colonial age (personal communication Anne Fox). Level 6 (50-56 cmbd) was excavated to the top of a yellow caliche lens $(56 \mathrm{cmbd} ; 2.04$ $m$ below asphalt) that separated the upper and lower midden deposits. The sediments from this level consisted of a silty clay with $2 \%$ to $5 \%$ gravel inclusions. Artifacts from the level consisted of bone, Spanish Colonial and Native American ceramics, glass, debitage, one biface, and burned rock (Table 6-6). The sediment from Level $7(56-60 \mathrm{cmbd})$ consisted of a yellow caliche with limestone gravels (30\%) and a very low density of artifacts; one bone and one Spanish Colonial sherd were recovered (Table 6-6). Level 8 (60-62 cmbd) consisted of the remaining yellow caliche lens. Artifacts collected included Spanish Colonial ceramics, bone, and burned rock (Table 6-6).

The lower midden deposit began at roughly $62 \mathrm{cmbd}$ (ca. $2.10 \mathrm{~m}$ below asphalt). The first level associated with

Table 6-6. Artifacts Recovered from Unit 6, 41BX1598

\begin{tabular}{|c|c|c|c|c|c|c|c|c|c|c|c|c|c|c|}
\hline \multirow[b]{2}{*}{ 商 } & \multicolumn{13}{|c|}{ Artifact Type } & \multirow[b]{2}{*}{$\stackrel{\bar{\pi}}{\theta}$} \\
\hline & 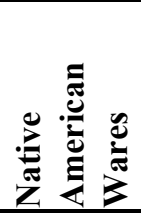 & 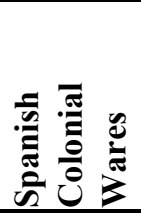 & 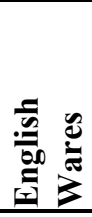 & $\frac{\tilde{\sigma}}{\tilde{\sigma}}$ & $\sum^{\bar{\pi}}$ & 苞 & 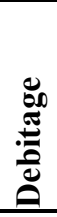 & 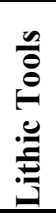 & 吢 & 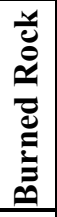 & 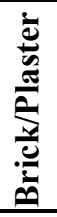 & 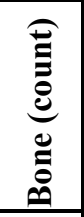 & 苞 & \\
\hline 1 & & 4 & 1 & & 1 & 1 & 3 & & & 1 & & 223 & & 234 \\
\hline 2 & & 11 & & & 4 & & 6 & & & & & 374 & 1 & 396 \\
\hline 3 & & 3 & 2 & & 1 & & 4 & & & 2 & & 184 & & 196 \\
\hline 4 & & 5 & & 2 & & & 2 & & & 1 & & 96 & & 106 \\
\hline 5 & 1 & 15 & 3 & & & & 3 & 1 & & 4 & 1 & 94 & & 122 \\
\hline 6 & 1 & 4 & & 1 & & & 3 & 1 & & 13 & & 30 & & 53 \\
\hline 7 & & 1 & & & & & & & & & & 1 & & 2 \\
\hline 8 & & 3 & & & & & & & & 2 & & 6 & & 11 \\
\hline 9 & 1 & 4 & & 1 & & & 3 & & 1 & 11 & & 30 & & 51 \\
\hline 10 & 1 & 3 & & & & & 1 & & & & & 38 & & 43 \\
\hline 11 & 1 & 7 & & & 1 & & 3 & 1 & & 6 & & 44 & & 63 \\
\hline 12 & & 5 & & 1 & & & & & & 3 & & 27 & & 36 \\
\hline 13 & & 4 & & & & & 3 & & & 14 & & 25 & & 46 \\
\hline 14 & & 2 & & & & & & & & 3 & & 4 & & 9 \\
\hline 15 & 1 & 1 & & 1 & & & & & & 1 & & 17 & & 21 \\
\hline 16 & & & & & & & & & & & & 21 & & 21 \\
\hline Total & 6 & 72 & 6 & 6 & 7 & 1 & 31 & 3 & 1 & 61 & 1 & 1214 & 1 & 1410 \\
\hline
\end{tabular}


this lower deposit was Level $9(62-70 \mathrm{cmbd})$. Sediments in this level consisted of a sandy clay. Cultural material recovered included bone, Spanish Colonial and Native American ceramics, glass, debitage, a gunflint, and burned rock (Table 6-6). Sediment in Level 10 (70-80 cmbd) was a brown sandy loam that contained Native American and Spanish Colonial ceramic, bone, and debitage (Table 6-6). Level 11 (80-90 cmbd) consisted of a dark gray sandy clay. Artifacts recovered included bone, a lithic tool, debitage, burned rock, Spanish Colonial and Native American ceramics, and unidentified metal (Table 6-6). Level 12 (90-100 cmbd) was a brown compact sandy clay. Artifacts from the level consisted of Spanish Colonial ceramics, one fragment of glass, burned rock, and bone (Table 6-6). The matrix in Level 13 (100-110 cmbd) was a loose sandysilty clay. Artifacts recovered included bone, burned rock, debitage and Spanish Colonial ceramics (Table 6-6). Level $14(110-120 \mathrm{cmbd})$ was similar to Level 13 and contained bone, burned rock, and Spanish Colonial ceramics (Table 6-6). Level 15 (120-130 cmbd) was a loose gravel on top of a yellow sandy gravel. The bottom of the midden, at approximately at $130 \mathrm{cmbd}$ (ca. $2.78 \mathrm{~m}$ below asphalt), was marked by this yellow sandy gravel. Artifacts from this level consisted of burned rock, bone, glass, a single Native American ceramic sherd, and a sherd of Spanish Colonial ceramic (Table 6-6). Level 16 (130-137 cmbd) was the termination of the unit. It consisted of yellow sandy gravels, and a small amount of bone was recovered (Table 6-6).

\section{Unit 7}

This 1-x-1-m unit was also excavated in the second midden feature located in the southwest portion of the project area (see Figure 5-7). Prior to the placement of Unit 7, the top portion of the midden (approximately $60-70 \mathrm{~cm}$, the upper deposit identified in Unit 6) was mechanically removed. The surface of Unit 7 at the time of excavation, then, was roughly $2.03 \mathrm{~m}$ below the asphalt. Unit 7 was terminated at $57 \mathrm{cmbd}$, or roughly $2.60 \mathrm{~m}$ below the asphalt layer, with $0.57 \mathrm{~m}^{3}$ of sediment being removed. The excavation was done in five levels, with the first four being $10 \mathrm{~cm}$ thick and the last level being $17 \mathrm{~cm}$ thick. While the excavation strategy was designed to sample the lower deposits in the midden, analysis presented in Chapter 8 suggests that this unit contained a mixture of both the upper and lower deposits. Charcoal was present throughout the excavation. Mussel shell was present in Levels 1, 2, 4, and 5, and burned clay was present in Level 1.

Level 1 of this unit ( $0-10 \mathrm{cmbd} ; 2.03-2.13 \mathrm{~m}$ below asphalt) consisted of a dark brown clay loam with $<10 \%$ limestone inclusions. Artifacts recovered from this level included bone, Spanish Colonial, English, and Native American ceramics, burned rock, glass, and one metal chocolatera handle (Table 6-7). Level 2 (10-20 cmbd) was a brown loam that had some clay content. Artifacts recovered from

Table 6-7. Artifacts Recovered from Unit 7, 41BX1598

\begin{tabular}{|c|c|c|c|c|c|c|c|c|c|c|c|c|}
\hline \multirow[b]{2}{*}{ 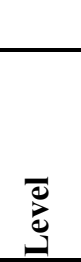 } & \multicolumn{11}{|c|}{ Artifact Type } & \\
\hline & 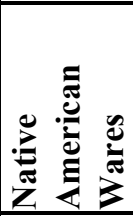 & 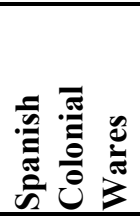 & 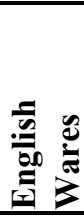 & $\begin{array}{l}\tilde{y} \\
\overline{\tilde{J}} \\
\end{array}$ & & 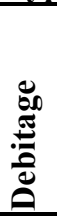 & 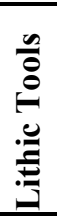 & 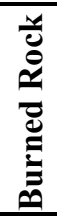 & 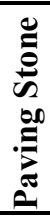 & 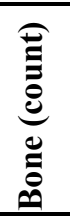 & U & है \\
\hline 1 & 2 & 11 & 1 & 1 & 1 & & & 4 & & 120 & & 140 \\
\hline 2 & & 10 & & & & 3 & & 7 & & 71 & & 91 \\
\hline 3 & 2 & 6 & 2 & & & 5 & 1 & 5 & & 77 & 1 & 99 \\
\hline 4 & & 3 & 7 & & & 4 & & 2 & & 88 & & 104 \\
\hline 5 & & 12 & & & 2 & 3 & 1 & 16 & 1 & 193 & & 228 \\
\hline Total & 4 & 42 & 10 & 1 & 3 & 15 & 2 & 34 & 1 & 549 & 1 & 662 \\
\hline
\end{tabular}


this level consisted of bone, Spanish Colonial ceramics, debitage, and burned rock (Table 6-7). Sediment in Level 3 (20-30 cmbd) was a loose, brown silty loam with limestone gravel inclusions. Artifacts present in the level were bone, burned rock, debitage, a lithic biface, one sherd of Chinese porcelain, and Spanish Colonial, English, and Native American ceramics (Table 6-7). The matrix from Level 4 (30-40 cmbd) was a light brown loam that contained bone, Spanish Colonial and English ceramics, debitage, and burned rock (Table 6-7). Level 5 (40 to $57 \mathrm{cmbd}$ ) was the termination of the unit. It consisted of a clay and caliche matrix. Artifacts from this level included bone, debitage, burned rock, a paving stone, two coins or possible medallions, and one Guerrero point (Table 6-7). 


\section{Chapter 7. Artifact Descriptions}

This chapter provides a more detailed description of the various categories of artifacts recovered during excavation at 41BX1598. Short summaries of ceramics, lithics, metal and glass, and miscellaneous items are provided. Faunal material, as well as flotation results, are also briefly discussed. Additional information on the faunal and floral recovery can be found in Appendices A and B of this report.

\section{Ceramic Artifacts}

A variety of ceramics were recovered from the project area, including 1,000 Spanish Colonial sherds and 295 sherds assigned to English wares. Figure 7-1 presents a temporal breakdown of the types discussed here. This breakdown, as well as the type descriptions themselves, are based primarily on work by Anne Fox (Fox n.d.; Tomka and Fox 1998; Zapata et al. 2000). At the time of the Spanish arrival in Texas, several local Native American groups were producing ceramics, generally classified in a Prehistoric context as Leon Plain. Native American production of ceramics continued through the Colonial period in mission contexts, though the ware is classified as Goliad. In appearance, Goliad ware is identical to Leon Plain ware. Early settlers in San Antonio used primarily Mexican-made ceramics, with English wares typically appearing in the region after about 1825. English wares are much more frequent in the San Antonio area after the Civil War.

\section{Spanish Colonial Ceramics: Unglazed Wares}

Of the Spanish Colonial ceramics encountered on this project, 235 were unglazed wares. This class includes Red Burnished ware, Tonalà Burnished ware, Valero, unknown unglazed, and Native American Goliad wares (Figure 7-2). Unglazed wares were recovered from throughout the project area, with most $(88 \%)$ recovered from the excavations conducted in the northern midden, with the southern midden accounting for less than $8 \%$.

\section{Red Burnished Ware ( $n=24)$}

This type is present in San Antonio ceramic collections dating from about 1725 through roughly 1800 (Figure 7-1). It is highly burnished (polished), usually dark red or occasionally black, sometimes with designs (Figure 7-2, a-b). The vessel form is usually small bowls. The place of manufacture for this type was probably Central Mexico.

\section{Tonalà Burnished Ware $(n=22)$}

This ceramic type dates from 1650 to about 1810 (Figure 7-1). This ceramic is a burnished ware with a fine, gray to tan paste that has a sweet, earthy smell. This ware is commonly painted with red, black and yellow designs (Figure 7-2, c). Vessel forms usually include small cups, plates and bowls. The location of manufacture for this ware was Tonalà in Jalisco, Mexico.

\section{Valero $(n=5)$}

This ceramic type occurred throughout the 1700 s to roughly 1825 (Figure 7-1). This ware is wheel-thrown, with occasional horizontal bands of red brown paint (Figure 7-2, d). The vessel form for this ware would have been water jars. This type would have been manufactured in Mexico.

\section{Native American Ware: Goliad $(n=141)$}

At the time of Spanish arrival, this ware was already in use by the local Native Americans. In the current context, we assign a beginning date of 1650 and a terminal date of around 1790 (Figure 7-1). This type of ceramic is a brownish to red colored ware with bone tempering (Figure 7-2, e-f). Vessel forms range from bowls to jars. 


\begin{tabular}{|c|c|c|c|c|c|c|c|c|c|c|c|c|}
\hline \multirow{3}{*}{$\begin{array}{l}\square \text { English Ware } \\
\square \text { Spanish Ware } \\
\text { Whiteware }\end{array}$} & \multicolumn{3}{|c|}{ 17th Century } & \multicolumn{3}{|c|}{ 18th Century } & \multicolumn{4}{|c|}{ 19th Century } & \multicolumn{2}{|c|}{ 20th Century } \\
\hline & \multicolumn{2}{|c|}{$1650 \quad 1675$} & 1700 & 1725 & 1750 & 1775 & 1800 & 1825 & 1850 & 1875 & \multicolumn{2}{|c|}{$1900 \quad 1925$} \\
\hline & & & & & & & & & & & & \\
\hline \multicolumn{13}{|l|}{ Annular/Banded Slip } \\
\hline \multicolumn{13}{|l|}{ Transfer Ware } \\
\hline \multicolumn{13}{|l|}{ Edge Ware/Cream Ware } \\
\hline \multicolumn{13}{|l|}{ Spongeware } \\
\hline Tumacacori & & & & & & & & 1 & 1 & & & \\
\hline \multicolumn{13}{|l|}{ Guanajuato } \\
\hline Tonalá Glazed & & & & & & $\square$ & & 1 & & & & \\
\hline \multicolumn{13}{|l|}{ Monterey Polychrome } \\
\hline \multicolumn{13}{|l|}{ Black Luster Glazed } \\
\hline \multicolumn{13}{|l|}{ Aranama } \\
\hline \multicolumn{13}{|l|}{ Wavy Rim Band } \\
\hline \multicolumn{13}{|l|}{ Galera } \\
\hline \multicolumn{13}{|l|}{ Molded Blue on White } \\
\hline \multicolumn{13}{|l|}{ Puebla Blue on White II } \\
\hline San Diego Polychrome & & & & & & 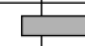 & & & & & & \\
\hline Huejotzingo Blue on White & & & & & & & & & & & & \\
\hline San Elizario & & & & & & 尚 & & & & & & \\
\hline Valero & & & & & & & & & & & & \\
\hline Red Burnished & & & & & & & & & & & & \\
\hline Chinese Porcelain & & & & & & & & & & & & \\
\hline Sandy Paste Ware & & & & & & & & & & & & \\
\hline Red Brown Ware & & & & & & & & & & & & \\
\hline Olive Jar & & & & & & & & & & & & \\
\hline San Agustín & & & & & & & & & & & & \\
\hline Puebla Blue on White & & & & 4 & 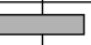 & & & & & & & \\
\hline Tonalá Burnished & & & & & & & $\square$ & & & & & \\
\hline Faience & & & $\square$ & & & & & & & & & \\
\hline Goliad (Native American) & & & & & & & & & & & & \\
\hline
\end{tabular}

Figure 7-1. Approximate age range of English and Spanish Colonial ceramic wares recovered from $41 B X 1598$. 


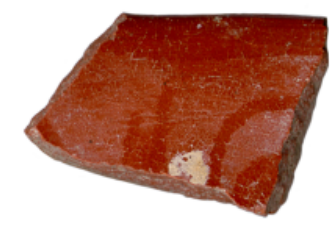

a

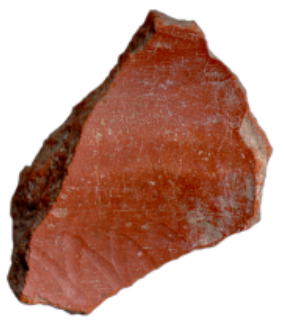

b

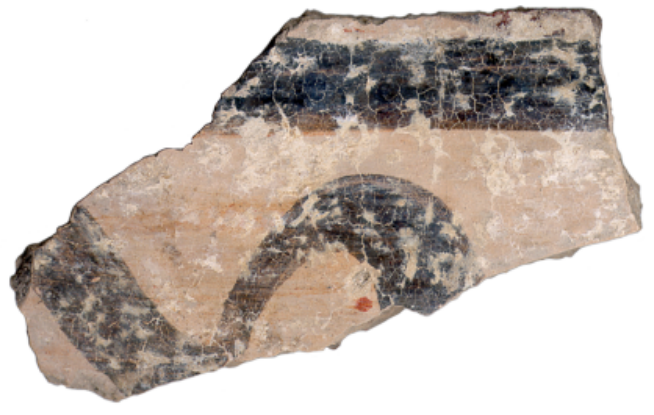

C

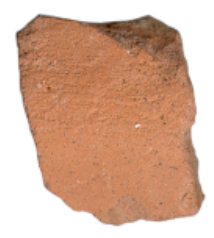

d

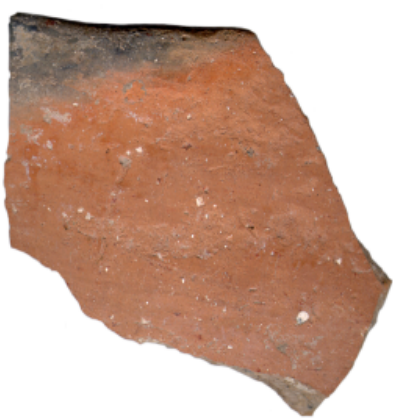

e

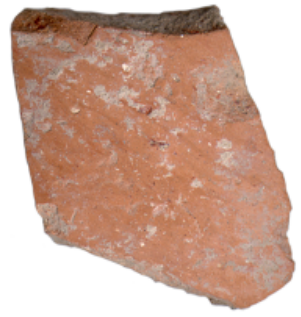

f

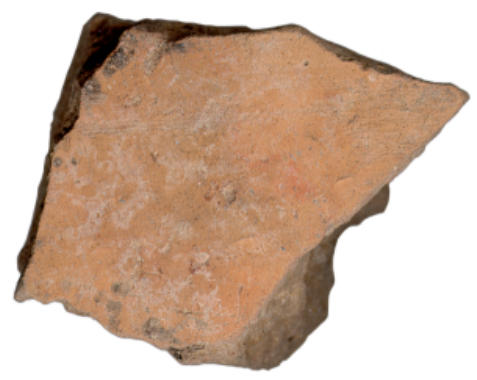

g

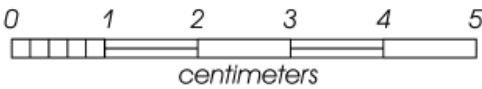

Figure 7-2. Examples of unglazed ceramics recovered from 41BX1598. a-b) Red Burnished; c) Tonalá Burnished; d) Valero; e-f) Goliad; g) unidentified unglazed.

\section{Unknown Unglazed Ware ( $n=43)$}

The collection contains several sherds $(n=43)$ of unglazed ceramics that represent unknown types (Figure 7-2, g). Many of these appear to have been wheel-thrown.

\section{Spanish Colonial Ceramics: Lead- Glazed Wares}

There were 463 lead-glazed sherds of various types recovered from excavation. The types include Sandy Paste, Galera, Olive Jar, Red Brown Ware, Mexican Black
Luster Ware, Tonalà, and unidentified sherds. Most of the lead-glazed ceramics (ca. 82\%) were recovered from excavations in the northern midden, with the southern midden accounting for $13 \%$ of these wares.

\section{Sandy Paste Ware $(n=240)$}

This ceramic type occurred throughout the eighteenth century (Figure 7-1). It has a pale green to yellow glaze over an orange-colored sandy paste. Often, this type displays obvious signs of the use of a potter's wheel. Decoration on this ceramic type consists of green rim bands and splotches of green (Figure 7-3 a-c). Vessel forms are usually bowls 
and jars (Fox n.d.; Zapata et al. 2000). Sandy Paste wares were produced in Mexico (Fox n.d.).

\section{Galera $(n=184)$}

This ceramic type is dated from as early as 1725 to roughly 1850 (Figure 7-1). Galera consists of a fine-textured red paste under a clear lead glaze. Decoration of these vessels consists of cream, brown, and green designs (Figure 7-3, d). Typically, vessel forms for this ceramic type are bean pots and chocolateras. Prior to 1750 , chocolateras were made of copper, but were abruptly replaced by ceramic vessels. This ware was manufactured Jalisco, Mexico (Gerald 1968:54).

\section{Red Brown Ware $(n=14)$}

This ware typically dates to the eighteenth century (Figure 7-1). It has a brown-tinted lead glaze over a fine red-brown paste. Vessel forms are usually flat-based plates. Red Brown ware was manufactured in Mexico.

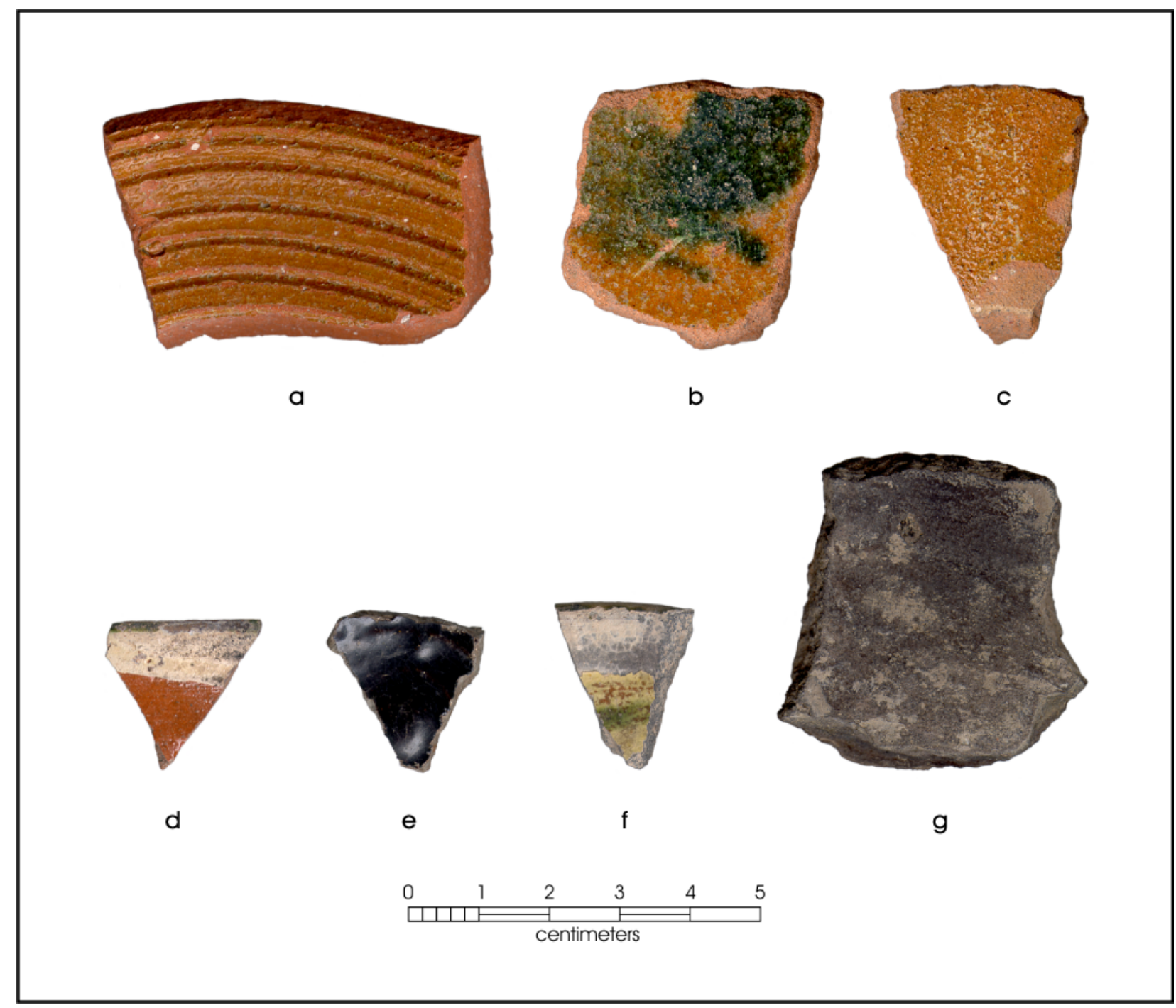

Figure 7-3. Examples of lead-glazed ceramics from 41BX1598. a-c) Sandy Paste; d) Galera; e) Black Luster; f) Tonalá Glazed; g) Olive Jar. 


\section{Black Luster Glaze $(n=3)$}

An estimated date for this ceramic type is between 1750 and 1850 (Figure 7-1). The glaze on this ware is intensely black and shiny. The paste is typically terracotta or buff colored. Decoration usually consists of a stamp-decorated or molded high relief (Figure 7-3, e). These types are usually deep bowls. Black Luster ware was produced in Puebla and Michoacan, Mexico.

\section{Tonalà Glazed ( $n=3)$}

This ware dates from 1780 to 1830 (Figure 7-1) and was manufactured in Jalisco, Mexico. This lead-glazed ceramic contains a white or cream-colored slip (Figure 7-3, f). Because the slip does not adhere well, it results in flaking and exposure of the underlying paste. Like the unglazed version of this ware, Tonalà lead-glazed has a unique and sweet earthy odor. Vessel forms are believed to be shallow bowls.

\section{Olive Jar $(n=7)$}

Olive jars in Texas date to between 1700 and 1800 (Figure 7-1). These vessels were utilized to ship wine and olive oil to the New World. This ware has a reddish to pale tan paste with an emerald to olive green glaze (Figure 7-3, g).

In addition to the types described, 12 unidentified leadglazed sherds were recovered from the site. That number includes one cream-colored lead glaze.

\section{Spanish Colonial Ceramics: Tin-glazed Wares}

The tradition of tin-glazed ceramics is Moorish in origin (Williams et al. 2004). It was later used by the Spanish and then introduced to the New World. Production of this ceramic type in the New World began in Mexico City and in other regions in Mexico. Three hundred and eighty-seven tin-glazed ceramics were recovered form CAR's work at the site, with most (ca. 82\%) being collected from excavations in the northern midden. The southern midden contained $10 \%$ of these wares. Major types identified included Guanajuato, San Agustín, Puebla Blue on White,
Huejotzingo Blue on White, San Elizario, Pueblo Blue on White II, and Wavy Rim Band. In addition to these major types, a number of other tin-glazed ceramic types occurred in small numbers at the site, including Molded Blue on White, Aranama, San Diego, Tucson Polychrome, Tumacacori, Tonalà tin-glazed, Faience, and Monterey.

\section{Guanajuato $(n=49)$}

This is an early nineteenth-century tin-glazed ware (Figure 7-1) that was produced in Guanajuato, Mexico. It has a cream glaze with green and brown decoration (Figure 7-4, a). The paste is a dark terracotta with a cream glaze. This type is usually found in plate, cup and bowl forms.

\section{San Agustín (n=7)}

This ceramic type dates from 1700-1780 (Figure 7-1). It typically has floral designs in blue with black accents (Figure 7-4, b) and vessel forms are usually plates, bowls and cups. The paste color is cream to buff. San Agustín was produced in Puebla, Mexico.

\section{Puebla Blue on White $(n=7)$}

This type dates from 1720-1760 (Figure 7-1). It has a white enamel with light and dark blue designs (Figure 7-4, c). The central part of the vessel sometimes depicts a crane figure. The paste is cream in color. Vessel forms are usually deep, brimmed plates, small cups, and bowls with everted rims. Puebla Blue on White was produced in Puebla and other locales in Mexico.

\section{Huejotzingo Blue on White $(n=14)$}

Huejotzingo was produced throughout much of the eighteenth and nineteenth centuries (Figure 7-1). The design consists of a single band of color at the rim. The paste color is cream or pink (Figure 7-4, d). Vessel forms are similar to plate and cup forms of Puebla Blue on White. This type derived its name from the town of Huejotzingo in Puebla, Mexico, where it was produced. 


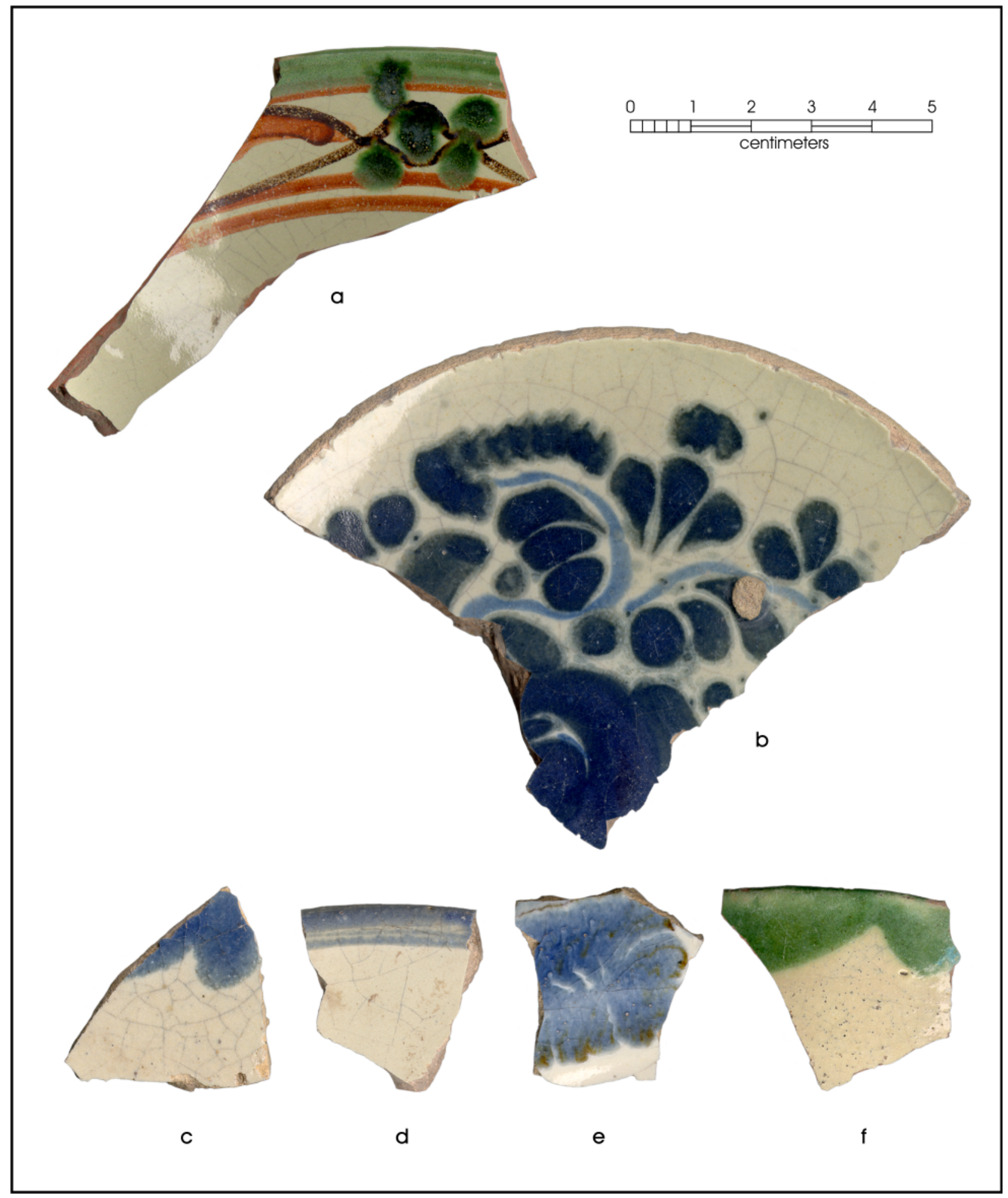

Figure 7-4. Examples of tin-glazed (majolica) ceramics from 41BX1598. a) Guanajuato; b) San Agustin; c) Puebla Blue on White; d) Huejotzingo; e) San Elizario; f) Wavy Band. 
San Elizario $(n=8)$

This type dates from 1750 to 1780 (Figure 7-1). It is similar to Puebla Blue on White with the exception of brown accents. The paste is pink and sometimes cream colored (Figure 7-4, e). Vessel forms are usually plates, bowls and cups.

\section{Puebla Blue on White II $(n=10)$}

This type dates to the late eighteenth century (Figure 7-1). Designs on this type consist of thin blue bands with blue dots and floral décor below the bands. The paste is a pale tan. Vessel forms consist of delicate cups and bowls only. This type was manufactured in Puebla, Mexico.

\section{Wavy Rim Band $(n=23)$}

Wavy Rim Band was produced between 1775 and roughly 1825 (Figure 7-1). It is identified by a wavy band that borders the rim of the vessel. The paste is typically cream in color (Figure 7-4, f). Vessel forms for this ceramic type are plates and cups. It also was also produced in Puebla, Mexico.

\section{Other Types}

A variety of other tin-glazed wares were recovered from the site. These types include one piece of Molded Blue on White, a sherd of Aranama, a sherd of San Diego Polychrome, one sherd tentatively identified as Tucson Polychrome (see Barnes and May 1972), two sherds of Tumacacori, three sherds of Tonalà tin-glazed, and five sherds of Monterey Polychrome. Finally, five sherds of Faience, a tin-glazed type not produced in Mexico but in France, were recovered. These recognized types date from throughout the eighteenth and nineteenth centuries (Figure 7-1). Note also that a significant number of tin-glazed sherds recovered from the project area were cataloged as undecorated $(n=175)$, unidentified polychrome $(n=24)$, or unknown blue on white $(\mathrm{n}=55)$.

\section{Chinese Porcelain}

Only two sherds of Chinese porcelain were recovered from the site. This type of porcelain is categorized as a Colonial ware since it was imported in the 1700s (Figure 7-1). The sherds from the site were of red-orange decoration. Both sherds came from the southern midden.

\section{English Ceramics: White Earthenwares}

There are different varieties of white earthenware that are divided by decoration applications. In all there was a total of 250 sherds that were classified as white earthen types. The sherds encountered during this project include creamware $(\mathrm{n}=53$; Figure $7-5, \mathrm{a})$, annular/banded slip $(n=14$; Figure 7-5, b), hand-painted $(n=24)$, edgeware $(\mathrm{n}=18$; Figure $7-5, \mathrm{c})$, spatter $(\mathrm{n}=2)$, sponge-stamped $(\mathrm{n}=1)$, transfer ware, including flowblue $(\mathrm{n}=49$; Figure 7-5, $d-f)$, ironstone $(n=12)$, plain undecorated $(n=69$; Figure $7-5, \mathrm{~g})$, and other whiteware $(\mathrm{n}=8)$. The recovery context for the English ceramics differs, at a general level, from that of the various Spanish Colonial wares discussed above. The northern midden only accounted for about $58 \%$ of the recovered English wares, and the southern midden only accounted for about $5 \%$ of the English ceramics. A high proportion (ca. 35\%) of the English ceramics was collected from trenches or various surfaces exposed during the site excavation.

Creamware and edgeware are probably the earliest of the white earthenwares encountered at the site (Figure 7-1). Edgeware was a popular British import during the last half of the eighteenth century and available until about 1860 (Fox et al. 1997:4). Transfer ware was produced in England starting in 1750 and was popular in the U.S. until the 1850s. Annular, spatterware, and hand-painted wares were introduced later and date as late as the early nineteenth century (Figure 7-1). Later white earthenwares that are in the collection include sponge-stamped, undecorated types and ironstone. Ironstone wares appeared more often in markets after the close of the Civil War (Zapata et al. 2000:42).

\section{English Ceramics: Stoneware}

There were nine sherds of stoneware recovered from the project area. Stoneware is a dense, hard ceramic with a white, tan or gray paste (Figure 7-5, h-i). The earliest dates for stoneware in North America were in the mid eighteenth century (Greer 1999:180). This ceramic was primarily used for kitchen operations (Zapata et al. 2000:42). Utilitarian stonewares of the eighteenth century typically had a 


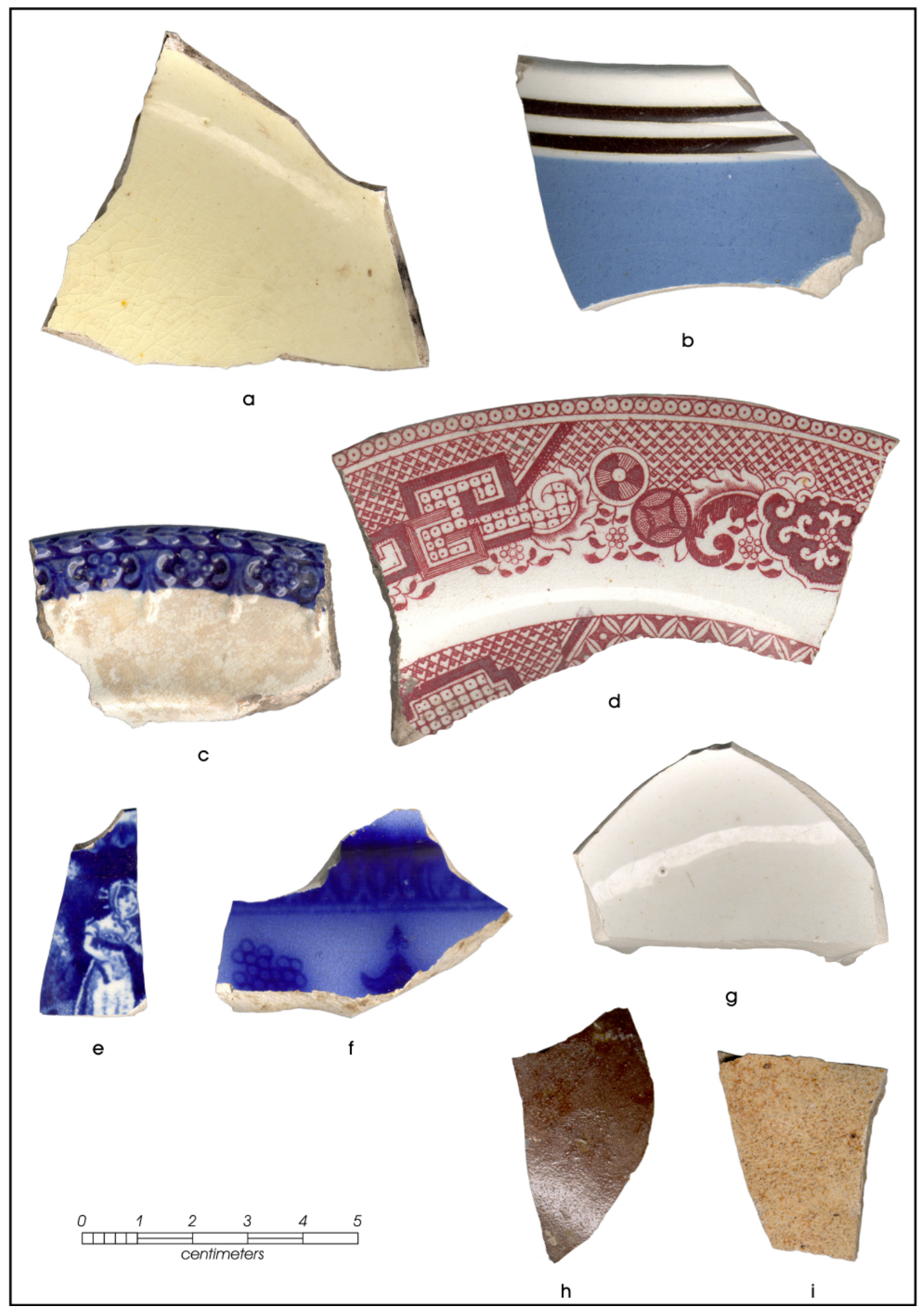

Figure 7-5. Examples of English ceramics recovered from 41BX1598. a) creamware; b) annular/ banded slip; c) edgeware; d) red transfer ware; e) blue transfer ware; f) flowblue transfer ware; g) undecorated white earthenware; $h$-i) stoneware. 
salt-glazed exterior and no interior glaze (Greer 1999:180). Types of stoneware recovered from the site include salt-glazed exteriors and unknown types.

\section{English Ceramics: Other}

Other English types that were recovered include copper lusterware $(n=1)$, yellowware $(n=21)$, and porcelain $(n=14)$. Copper lusterware dates to the nineteenth century and has a shiny luster appearance. Yellowware dates to the late nineteenth century to early twentieth century (Figure 7-1). The type of yellowware encountered in this collection is Rockingham. In addition to Chinese porcelain, English porcelain was also recovered. It dates to the mid to late nineteenth century.

\section{Other Ceramics}

Of the ceramics collected and recovered at the site, five did not adhere to the already discussed categories. Two Italian majolica sherds (tin-glazed) were included in the collection. These sherds have white enamel on one side, a lead glaze on the opposite side, and a terracotta paste. One unglazed flowerpot base was recovered, along with a lead-glazed piece that was cream in color.

\section{Chipped Lithic Artifacts}

Three hundred and thirteen lithic artifacts were recovered from the surface collections and excavations performed at 41BX1598. Most of these were collected from the northern midden (ca. 78\%) with about $18 \%$ collected from the southern midden. The lithic artifacts were categorized into the following classes: gunflints $(n=6)$, cores $(n=1)$, debitage $(n=291)$, projectile points $(n=2)$, bifaces $(n=10)$, and edge-modified flakes $(\mathrm{n}=3)$. All of these artifacts are made from chert that is probably from the San Antonio region. The continuing use of stone technology during periods where metal was available has been documented at other Colonial-age sites. For example, Fox (1977) reports the recovery of a variety of chipped stone material from Colonial contexts (see also Fox et al. 1989, 1997).

Six gunflints were recovered from the excavations (Figure 7-6). Villalobos (2003:59-60) has identified a variety of different types of gunflints, primarily tied to the degree of manufacture (flaking) and color. It appears that four of the gunflints from 41BX1598 are bifacially worked while the remaining two appear to fit the local spall type (Villalobos 2003:59-60). Villalobos notes that presidio sites are more likely to have a higher percentage of blade and scraper types of gunflints produced by soldiers. In mission contexts, there appears to be a higher percentage of biface and local spall gunflints which have been manufactured by natives (Villalobos 2003:68).

Included in the lithic specimens recovered from the site were pieces of debitage $(n=291)$, one core, two projectile points and lithic tools $(n=13)$. The two projectile points encountered were classified as Guerrero points (Figure 7-7) and are commonly found in mission settings (Tomka and Fox 1998:28). In addition, 10 bifaces and three edge-modified flakes were recovered.

\section{Metal and Glass}

Several metal items were recovered from surface collections and test units. A majority of the metal was not identifiable $(550.77 \mathrm{~g})$. One copper chocolatera handle was recovered from Unit 7, Level 1. Prior to 1750, chocolateras were made of copper, such as the one recovered at this site. Galera leadglazed vessels abruptly replaced the copper vessels. This artifact denotes that Midden 2 definitely dates prior to the orphanage occupation, which occurred in the late 1800s. Several copper fragments were recovered from the excavations $(\mathrm{n}=40)$. They appear to be sheets of copper with punched out marks. It is possible that the copper fragments were remnants of button production (Clint McKenzie, personal communication 2004). One thimble was also collected from the site. One metal item that is quite possibly from the time of the orphanage was a copper bell that was encountered during removal of overburden to define the orphanage walls (Figure 7-8).

Two silver coins or medallions (Unit 7, Level 5) and one copper coin (Unit 2, Level 3) were recovered. The two silver coins/medallions are corroded and a clear identification is not possible (Figure 7-9). Both coins/medallions measure $2 \mathrm{~mm}$ in thickness and $17 \mathrm{~mm}$ in diameter. The copper coin is in fairly good condition with very little corrosion. It is identified as a De La Garza coin, which was minted in San Antonio by José Antonio De La Garza, the local postmaster. In 1818, he was given permission from the military Governor of San Antonio to coin 8,000 jolas. The jolas had the value of $1 / 2 \operatorname{Real}(1 / 16$ of a dollar). It depicts the lone star on one side and "JAG" (de la Garza'a initials), 


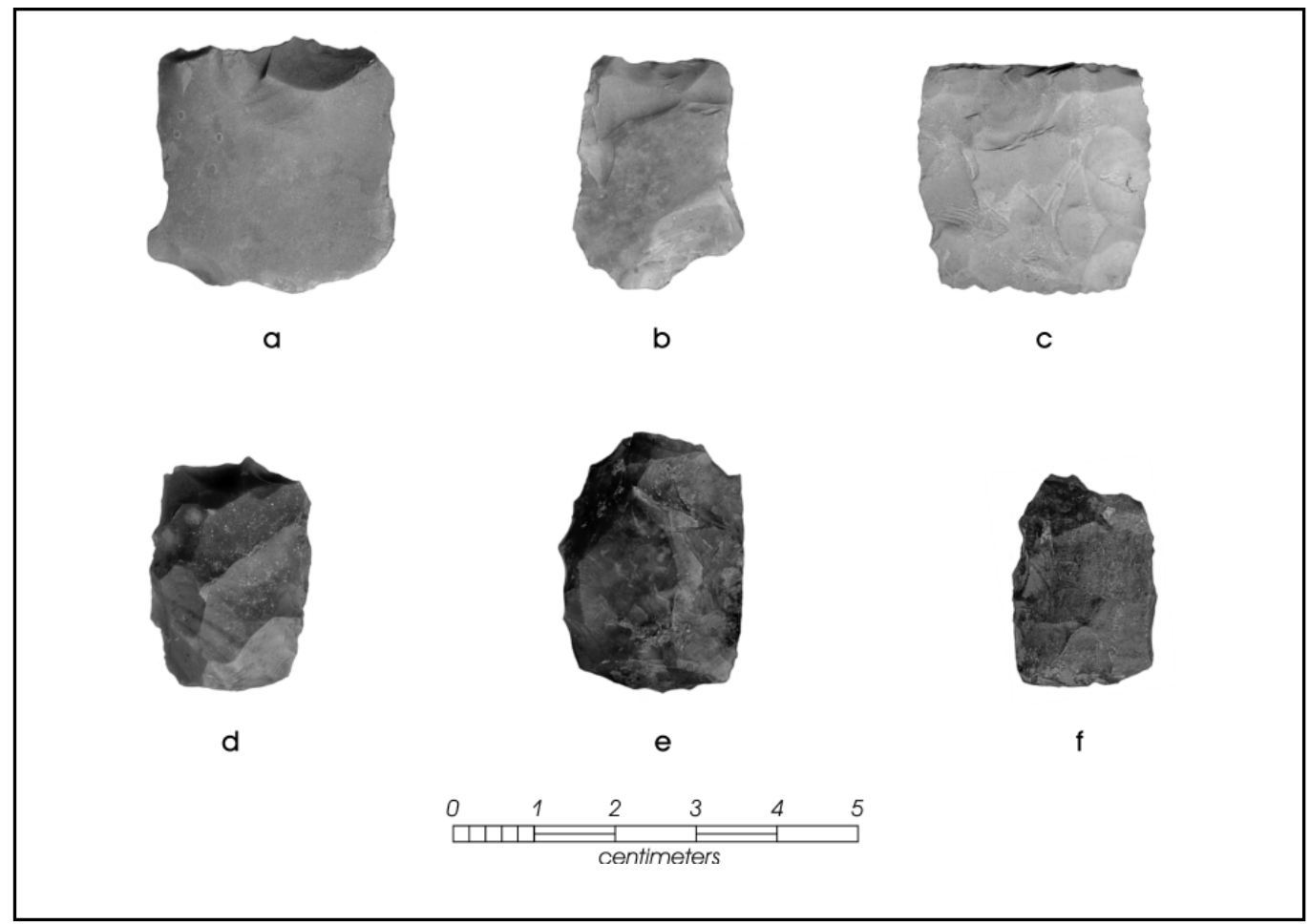

Figure 7-6. Gunflints recovered from 41BX1598. a-b) flake type; c-f) bifacially worked.

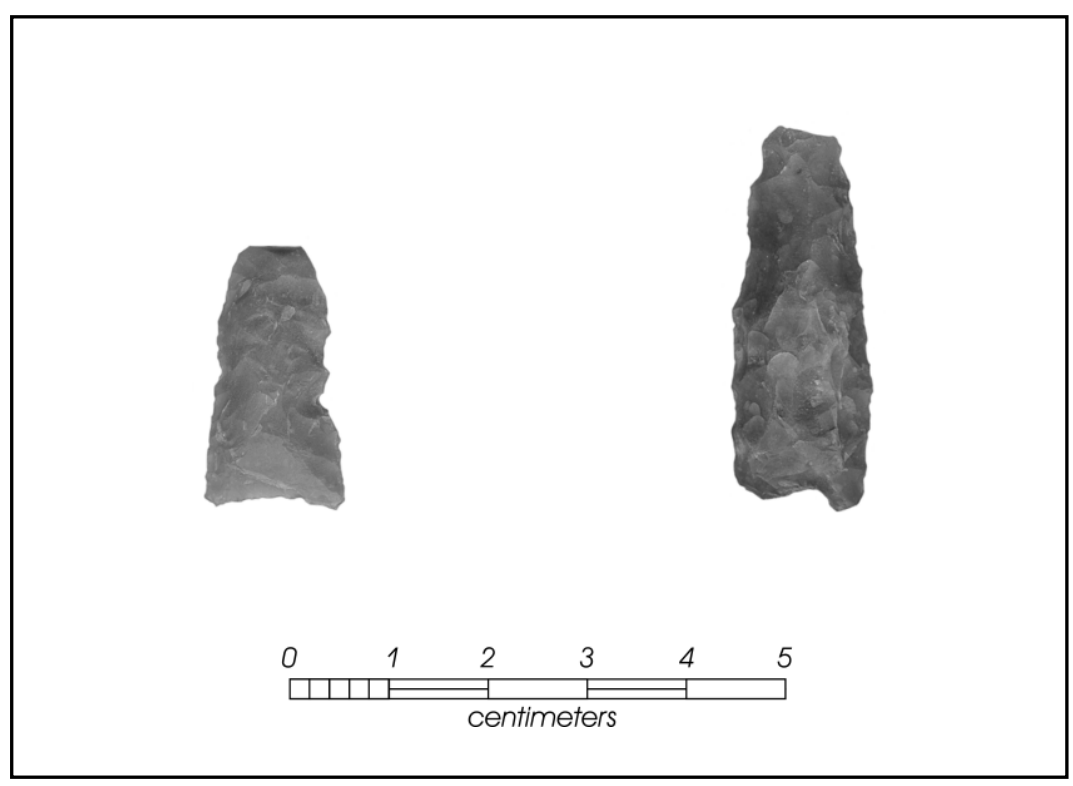

Figure 7-7. Projectile points recovered from $41 B X 1598$. 


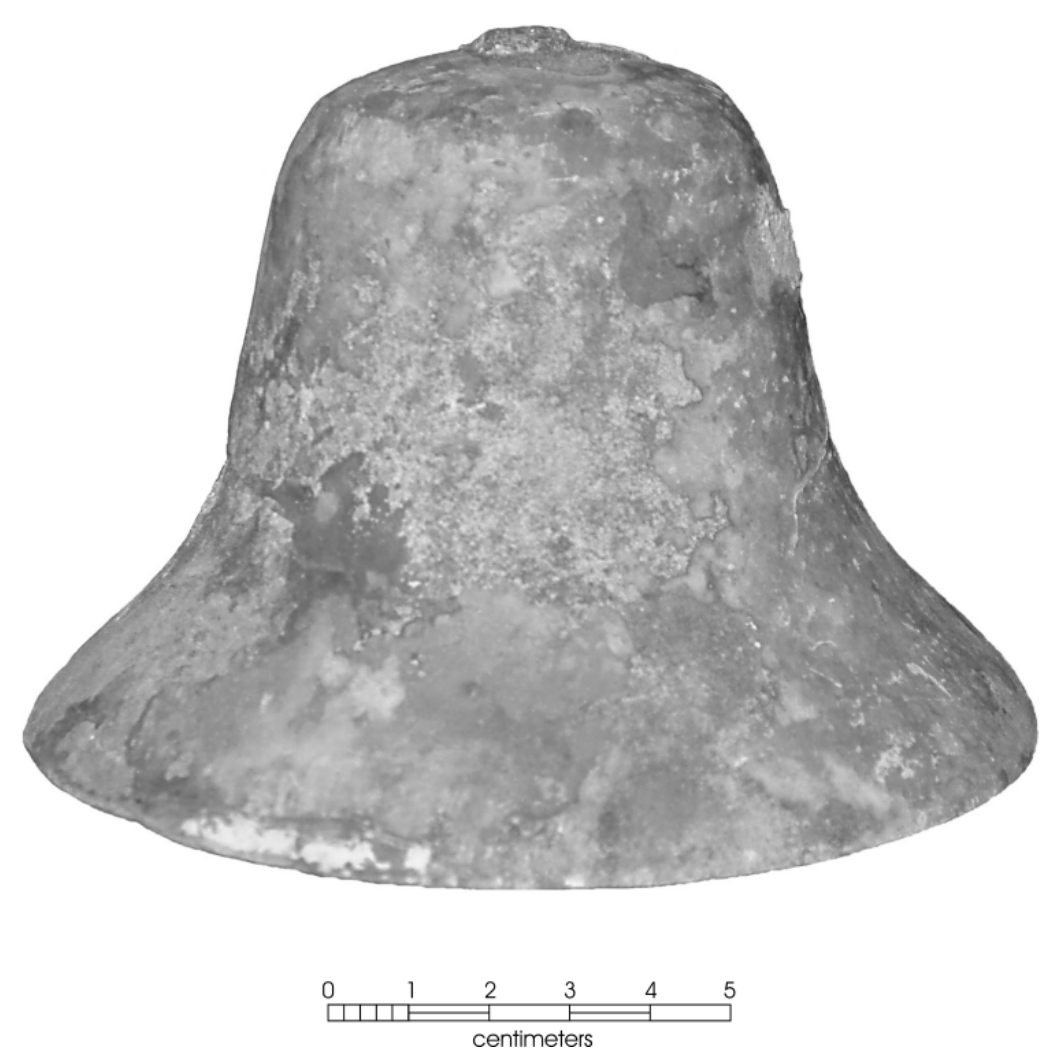

Figure 7-8. Copper bell, probably dating from the period of the St. Joseph's Orphan Asylum.

" $1 / 2$ " and " 1818 " on the other (Figure 7-10). The jolas were minted at a building on Houston and Soledad streets (Orozco 2004). It measures $2 \mathrm{~mm}$ in thickness and $17 \mathrm{~mm}$ in diameter. The de la Garza coin was recovered from Unit 2, Level 3, in the northern midden.

Various bottles and glass fragments were also recovered from the site. The glass colors include amber, aqua, blue, brown, clear and olive glass. The majority of glass recovered is olive, which ranges in date from the 1700s into the 1800s. Most of the olive glass is probably from wine bottles which would have been consumed during Colonial and post-Colonial times.

\section{Miscellaneous Items}

Four artifacts where cataloged as activity items; they consist of a penny doll, a portion of a porcelain doll's face, and two gaming pieces. These items can also be classified as toys and games. The penny doll or "frozen charlotte" is a cheaply made doll of a glazed porcelain. These dolls date to the mid 1850s (Fox et al. 1997:61). The doll was encountered in an unidentified pit that was uncovered during overburden removal. The porcelain doll face dates to the $1800 \mathrm{~s}$ as well, and was recovered from ST 1.

Two disc-shaped pieces were also encountered during excavation, one made of limestone the other of sandstone. These discs were classified as gaming pieces or cuatros. They are usually found in historical contexts. Apparently, the game they may have been used is in still played by the Tarahumara Indians of Northern Mexico (Fox et al. 1997, after Schuetz 1969). The limestone piece was encountered in Unit 2, Level 1, and the sandstone piece was recovered in Unit 4, Zone 4 . There are no solid dates on gaming pieces but they have been previously reported in mission contexts (Zapata et al. 2000). 


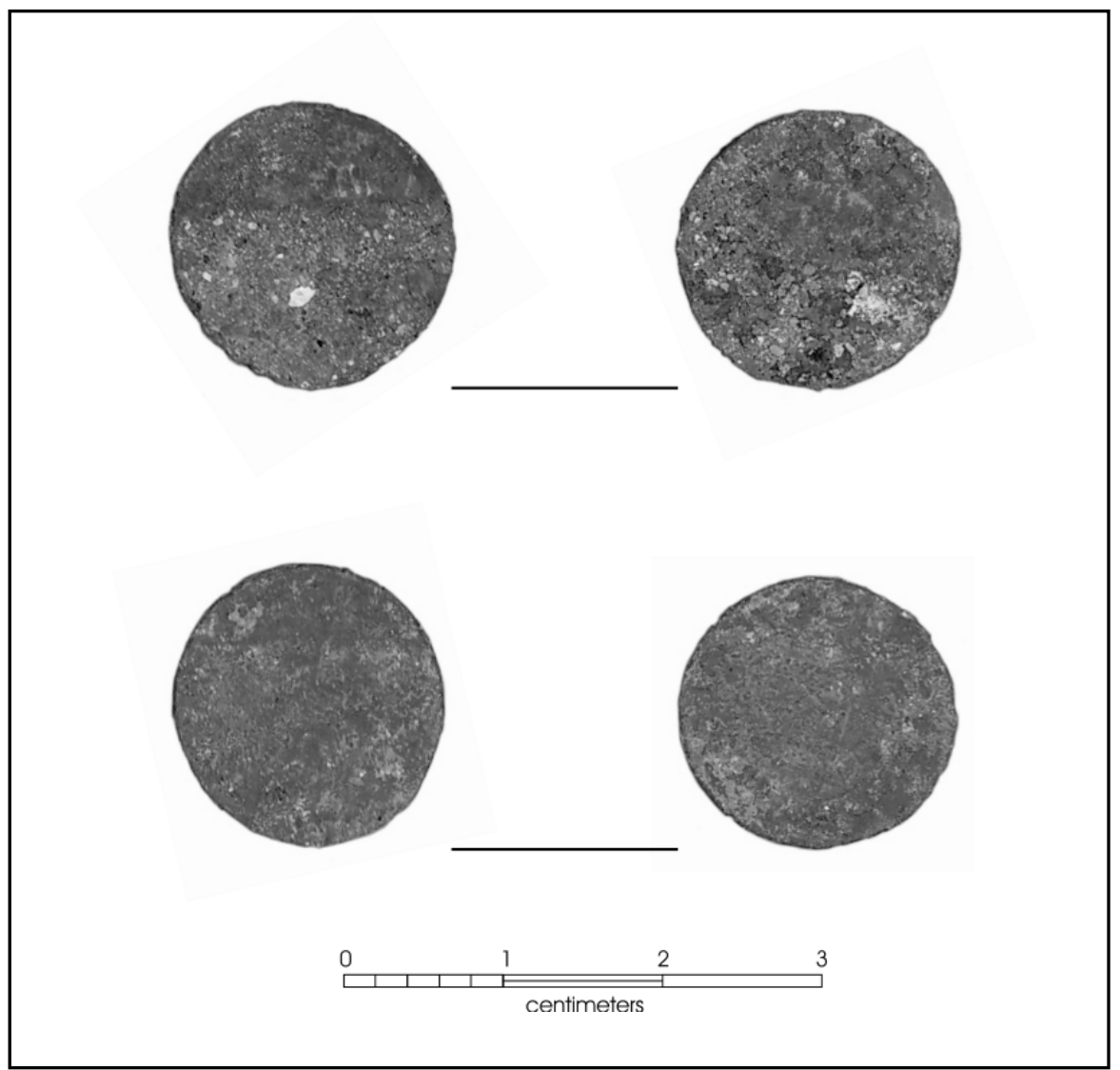

Figure 7-9. Possible silver coins or medallions recovered from Midden 2 (southern midden).

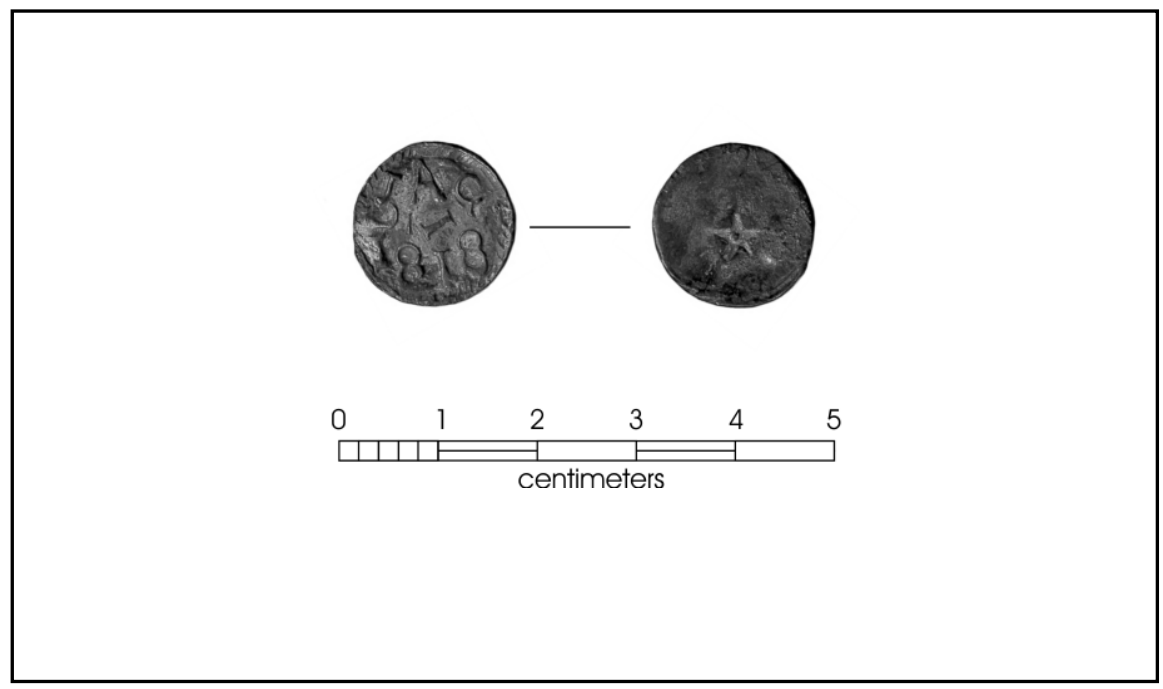

Figure 7-10. De la Garza coin, dating to 1818, recovered from Midden 1 (northern midden). 
Two partial clay pipes were also recovered during excavations. One specimen is a partial bowl and stem piece (surface collection). The second specimen is a bowl fragment. Both are a terracotta color with some indications of burning on the interiors of the bowls. One copper thimble was recovered from Unit 4, Zone 4, and one small glass blue bead came from Unit 5, Zone 3. Fourteen buttons were recovered from excavations and surface collections. Button materials include bone, shell, porcelain, plastic, and copper.

There were a variety of other items in the collection that range from construction material to miscellaneous items. One piece of painted plaster was also recovered (Unit 4, Zone 1). On surface, during overburden removal, one wooden post was recovered. Bricks $(n=15)$ were collected from excavations and surface collections as well and ranged from modern to quite possibly Colonial in age.

Burned clay ( $30.9 \mathrm{~g}$ ) was recovered, mainly from excavations within the northern midden. In addition, 484 pieces of burned rock were collected $(6.64 \mathrm{~kg})$.
Mussel shell umbos and fragments were also collected from excavations. In total, there was four mussel umbos and $35.70 \mathrm{~g}$ of mussel shell. The shell was encountered at various levels in the excavations.

Finally, note that a marble plaque, measuring $50 \times 30 \mathrm{~cm}$ in size, was recovered (Figure 7-11). The plaque clearly identifies the orphanage.

\section{Vertebrate Faunal Remains}

The largest category of material recovered from the site is vertebrate faunal material. A total of 13,368 vertebrate faunal items was recovered and analyzed. There was a variety of species identified by Barbara A. Meissner (Table 7-1; see also Appendix A). As shown in Table 7-1, the vast majority of the bone (ca. 90\%) was fragmentary and only could be classified as unknown mammal. Nevertheless, identified specimens included a variety of domesticated taxa (e.g., cattle, chicken, pig, goat, and sheep) as well as a wide

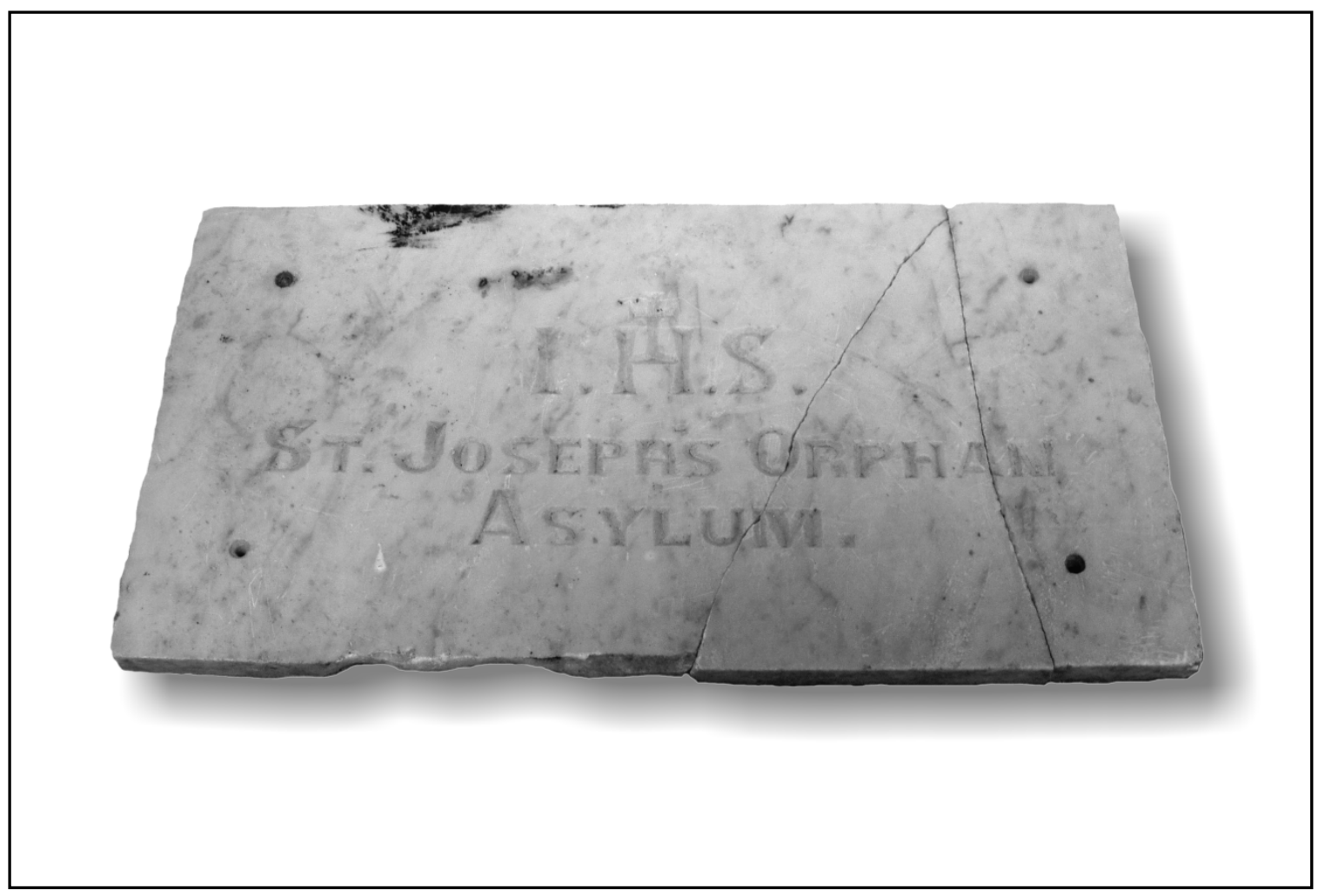

Figure 7-11. Marble plaque (50 x $30 \mathrm{~cm})$ recovered during surface stripping at $41 B X 1598$. 
variety of wild taxa (bison, bob cat, antelope, deer, fish, turtle, bird). While many of the species shown in Table 7-1 are commonly found in Spanish Colonial settings around the San Antonio area (Meissner, personal communication 2004; Meissner 1997:22), roughly $35 \%$ of the assemblage identified to the species level are wild animals.

Interestingly, only a single rodent specimen was identified in the assemblage. While the absence of the European $R$. rattus, the black or roof rat, from Colonial-age deposits has been noted elsewhere in sites from the region (cf., Davidson and Clark 1978:136; Hard et al. 1995:83; Meissner 1997:25), suggesting that the animal was not common during this period, the low number of rodent remains is surprising, especially given that roughly $97 \%$ of the faunal material was recovered from midden context. A majority of the bone specimens (ca. 84\%) were from test units excavated in the northern midden feature, while roughly $13 \%$ of all bone at the site was associated with excavation units in the southern midden.
Of the bone identified and cataloged, two specimens were cataloged as bone tools and one as worked bone (Figure 7-12). The first specimen may have been ornamental, mostly due to its small and delicate appearance. The second bone tool may have been a "flesher", which would have been utilized to remove flesh from animal hides.

\section{Macrobotanical Remains}

As noted in the previous chapter, flotation samples were taken from each zone in Units 4 and 5 excavated in the northern midden. Eight samples, all from Unit 5, were processed and submitted to Dr. J. Phil Dering for analysis. Table 7-2 lists the identified wood remains by zone (see also Appendix B). Carbonized wood was recovered from every zone, with mesquite dominating (ca. 95\%) the wood types. Interestingly, there are no non-local woods represented in the recovered material. In addition to the recovered woods, pecan shell was recovered from Zone 2, and mesquite seeds were recovered from Zones 7 and 8. No cultigens were recovered from the samples.

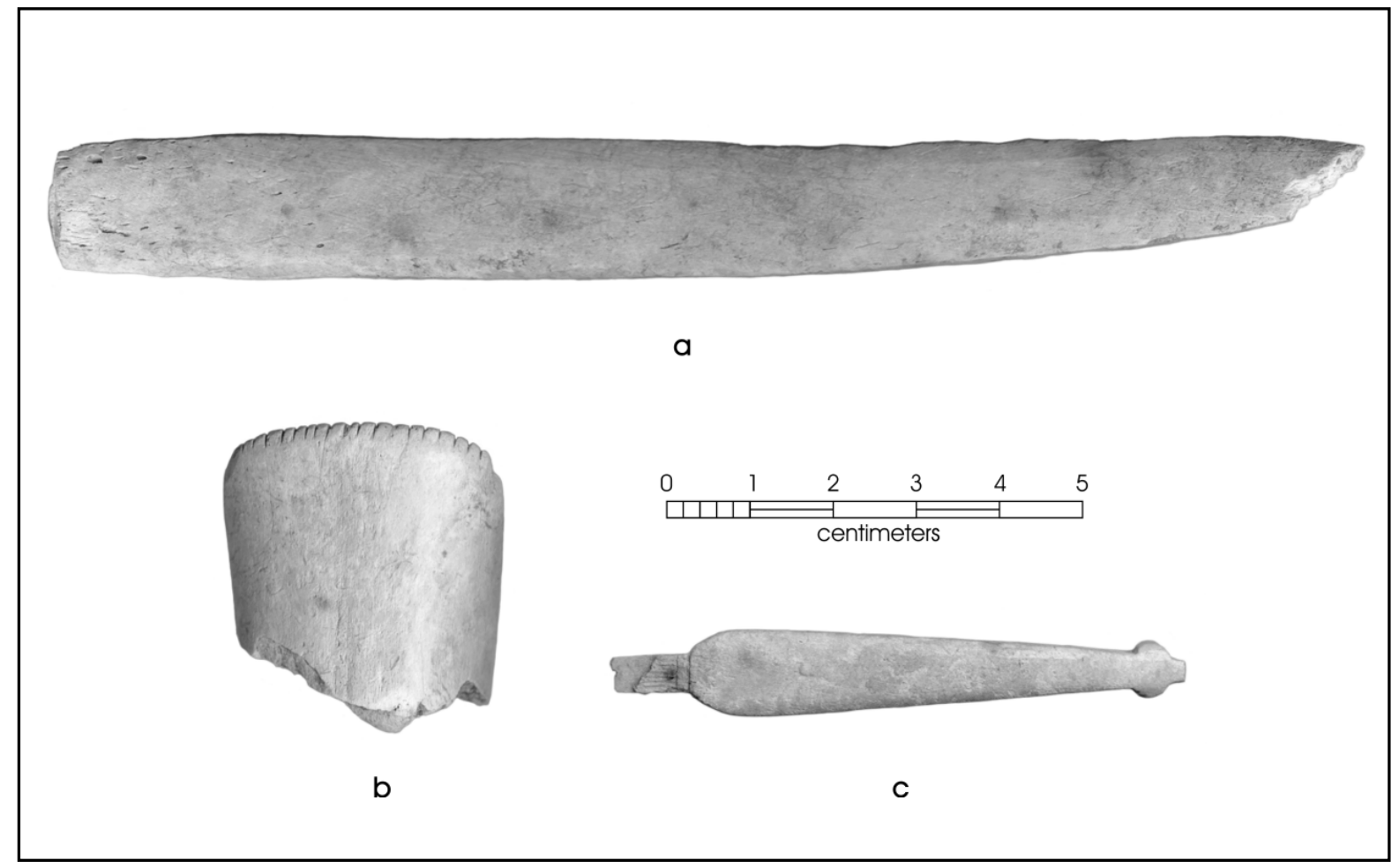

Figure 7-12. Worked bone (a) and bone tools from 41BX1598. Note that b may have been a "flesher" for hide processing. 
Table 7-1. Faunal Material Recovered from 41BX1598

\begin{tabular}{|c|c|c|c|}
\hline Scientific Name & Common Name & NISP* & $\%$ of Total NISP \\
\hline Antilocapra americana & Pronghorn & 3 & $0.30 \%$ \\
\hline Artiodactyla & Deer/goat/sheep/pig & 289 & $24.90 \%$ \\
\hline Bison bison & Bison & 35 & $3.00 \%$ \\
\hline Bos taurus & Cattle & 114 & $9.80 \%$ \\
\hline Bovinae & Cattle/Bison & 520 & $44.90 \%$ \\
\hline Branta sp. & Geese & 1 & $0.10 \%$ \\
\hline Buteo sp. & Hawk & 1 & $0.10 \%$ \\
\hline Canis sp. & Dog/Coyote & 8 & $0.70 \%$ \\
\hline Capra hircus & Goat & 2 & $0.20 \%$ \\
\hline Caprinae & Sheep/Goat & 38 & $3.30 \%$ \\
\hline Cathartes aura & Turkey Vulture & 1 & $0.10 \%$ \\
\hline Emydidae & Turtles & 1 & $0.10 \%$ \\
\hline Equus caballus & Horse & 1 & $0.10 \%$ \\
\hline Equus sp. & Horses & 3 & $0.30 \%$ \\
\hline Felis domesticus & House Cat & 1 & $0.10 \%$ \\
\hline Gallus gallus & Chicken & 21 & $1.80 \%$ \\
\hline Ictalurus sp. & Catfish & 4 & $0.30 \%$ \\
\hline Lepus californicus & Jackrabbit & 2 & $0.20 \%$ \\
\hline Lynx rufus & Bobcat/Lynx & 1 & $0.10 \%$ \\
\hline Meleagris gallopavo & Turkey & 8 & $0.70 \%$ \\
\hline Odocoileus virginianus & White-tailed Deer & 44 & $3.80 \%$ \\
\hline Ovis aries & Sheep & 29 & $2.50 \%$ \\
\hline Pecari tajacu & Collared Peccary & 10 & $0.90 \%$ \\
\hline Perciformes & Perch-Like Fish & 3 & $0.30 \%$ \\
\hline Pylodictus olivaris & Flathead Catfish & 1 & $0.10 \%$ \\
\hline Rodentia & Rodents & 1 & $0.10 \%$ \\
\hline Sus scrofa & Pig & 13 & $1.10 \%$ \\
\hline Testudines & Tortoises/Turtles & 4 & $0.30 \%$ \\
\hline Total NISP & & 1159 & \\
\hline Unidentified Bird & & 162 & \\
\hline Unidentified Fish & & 24 & \\
\hline Unidentified Mammal & & 12023 & \\
\hline Total & \multicolumn{3}{|c|}{13368} \\
\hline
\end{tabular}

* NISP $=$ Number of Identified Specimens 


\section{Summary}

Test unit excavations, shovel testing, backhoe trenching, and stripping conducted at the site of the proposed San Fernando Community Center (41BX1598) produced a wide variety of artifacts, most of which appear to date primarily to the Colonial period. Much of the assemblage comes from two midden deposits. The ceramic assemblage is dominated by Colonial-age sherds, with smaller numbers of English whitewares. Lithic material, including two projectile points, six gunflints, and 13 other lithic tools, were recovered from throughout the deposits, though this material was concentrated in the middens. The presence of a chipped stone assemblage provides continued evidence that stone technology endured throughout the Colonial period. A variety of other artifacts, including glass and metal, were also present. A Garza coin was also recovered. Perhaps the most interesting aspects of this work are the results of the faunal and floral inventories. A surprisingly large component of the faunal material (ca. 35\%) represents wild species, including bison, antelope, and white-tailed deer. The flotation results produced only local woods, and while seeds and nuts were recovered, the assemblage lacked any evidence of cultigens. The lack of cultigens and non-local woods, and the potential importance of wild species, suggests that while aspects of the recovered artifacts reflect the use of new technologies (e.g., some ceramic types, metal, glass), other elements (e.g., chipped stone tools, bone tools) continued in operation, and subsistence practices may have continued to rely heavily on wild species.

Table 7-2. Wood Recovery from Flotation Samples in Northern Midden (Midden 1)

\begin{tabular}{|c|l|l|c|r|}
\hline Zone & Scientific Name & Common Name & Count & \% of Total \\
\hline 1 & Prosopis glandulosa & Mesquite & 27 & $12.74 \%$ \\
\hline 1 & Salicaceae & Willow/Cottonwood & 1 & $0.47 \%$ \\
\hline 2 & Carya illinoiensis & Pecan & 2 & $0.94 \%$ \\
\hline 2 & Juniperus sp. & Juniper, Cedar & 3 & $1.42 \%$ \\
\hline 2 & Prosopis glandulosa & Mesquite & 20 & $9.43 \%$ \\
\hline 3 & Juniperus sp. & Juniper, Cedar & 1 & $0.47 \%$ \\
\hline 3 & Prosopis glandulosa & Mesquite & 17 & $8.02 \%$ \\
\hline 4 & Juniperus sp. & Juniper, Cedar & 1 & $0.47 \%$ \\
\hline 4 & Prosopis glandulosa & Mesquite & 24 & $11.32 \%$ \\
\hline 5 & Prosopis glandulosa & Mesquite & 22 & $10.85 \%$ \\
\hline 6 & Prosopis glandulosa & Mesquite & 3 & $10.38 \%$ \\
\hline 7 & Juniperus sp. & Juniper, Cedar & 50 & $1.42 \%$ \\
\hline 7 & Prosopis glandulosa & Mesquite & 2 & $23.58 \%$ \\
\hline 8 & Berberis trifoliata & Agarita & 1 & $0.94 \%$ \\
\hline 8 & Juniperus sp. & Juniper, Cedar & 15 & $0.47 \%$ \\
\hline 8 & Prosopis glandulosa & Mesquite & 212 & $100.00 \%$ \\
\hline Total & & & & $23 \%$ \\
\hline
\end{tabular}




\section{Chapter 8. Architecture and Features}

CAR's work at 41BX1598 uncovered a variety of features and walls, including evidence of walls associated with St. Joseph's Orphan Asylum, six isolated pit features defined in backhoe trenches, a wall possibly associated with the Presidio San Antonio de Béxar, and two midden features that date primarily to the Colonial period. The current chapter provides a summary of these features as well as architectural details revealed by CAR's work at 41BX1598.

\section{Architectural Details}

As noted in Chapter 4, Sanborn maps from 1877, 1885, and 1911 clearly outline a series of structures that were constructed on the property. Not surprisingly, our archaeological investigation began to reveal walls after the removal of only a few centimeters of asphalt at the site. Figures 8-1 outlines the walls after the mechanical stripping and backhoe trenching were completed. Figure 8-2 provides a reconstruction of the buildings using the wall segments and the Sanborn maps. Many of the walls appear to align with the structures depicted on the Sanborn maps. Most appear to be from St. Joseph's Orphan Asylum. Note that a variety of artifacts were collected during the initial phases of overburden removal, and most seem to date to this time period (see Appendix C), including the marble plaque pictured in Figure 7-11. Several wall segments, however, depicted in purple on Figure 8-2, could not be clearly identified to any particular time period. Nevertheless, most of these are probably associated with structures shown on the Sanborn maps, with several representing interior walls of the hardware store and the hospital.

Note that a suspected Colonial-age wall segment, located during the last phase of overburden removal, does seem to correspond with walls identified on the 1877 Sanborn drawing. This does not mean that the wall does not predate 1877 . This wall was located in the extreme southwestern portion of the project area (see Figures 8-2 and 8-3). As can be seen in Figure 8-4, the bottom portion of the wall was constructed of rough stone and ran parallel with Camaron Street, though the top portion of the wall represents later additions. The mode of construction of the lower wall and the location of the wall suggest it may be the remains of the Presidio San Antonio de Béxar. Prior to removal, the wall was photographed in detail. No artifacts were directly found in association with the wall; however, a small piece of what was thought to be charcoal was collected from the lower portion of the wall. The piece was later determined to be asphalt. Given the lack of associated artifacts, the presence of asphalt, and the rough correspondence between the 1877 Sanborn drawings and the current wall, we are unable to confirm that the lower section of the wall is, in fact, Colonial in age. Nonetheless, the method of construction is identical to other Colonialage walls and foundations in the San Antonio area.

As noted in Chapter 6, stone construction was also seen in the initial stripping around the northern midden. This wall section that was explored with Unit 3. In this case, the wall consisted of cut stone and clearly aligned with construction of the hospital as shown on the 1877 Sanborn map. In addition, the Colonial-age midden feature was under the wall segment (see Figure 8-5). It is highly unlikely, then, that this second wall segment was Colonial in age.

\section{Isolated Pits}

In addition to the wall segments, the backhoe trenching uncovered six small pit features, and a second midden located to the south (Figure 8-6). BHT 3 contained three pit features. Pit 1 consisted of a shallow pit that contained a light concentration of charcoal. No artifacts were observed in this pit feature. Pit 2 was approximately $3 \mathrm{~m}$ in width and located approximately $3 \mathrm{~cm}$ below the asphalt. Artifacts noted in the feature included English whitewares, clear bottle glass, metal, saw-cut bone, flat glass, and a heavy concentration of charcoal, stone, and asphalt. The feature was clearly post-Colonial in age, with ceramics from the feature dating to the late 1800 s and early $1900 \mathrm{~s}$. The feature appeared to primarily reflect construction debris. Pit 3 was $90 \mathrm{cmbs}$ and roughly $80 \mathrm{~cm}$ in diameter. It contained brick, saw-cut bone, and a light scatter of charcoal. No collections were made from this pit feature, and the temporal association of the pit is not known.

BHT 4 exposed two pit features (see Figure 8-6). Pit 4 was roughly $2 \mathrm{~m}$ in diameter and was located at $95 \mathrm{cmbs}$. A light concentration of bone and charcoal were noted in the pit but not collected. The temporal association of this feature is not known. Pit 5 was $4 \mathrm{~m}$ long and at 


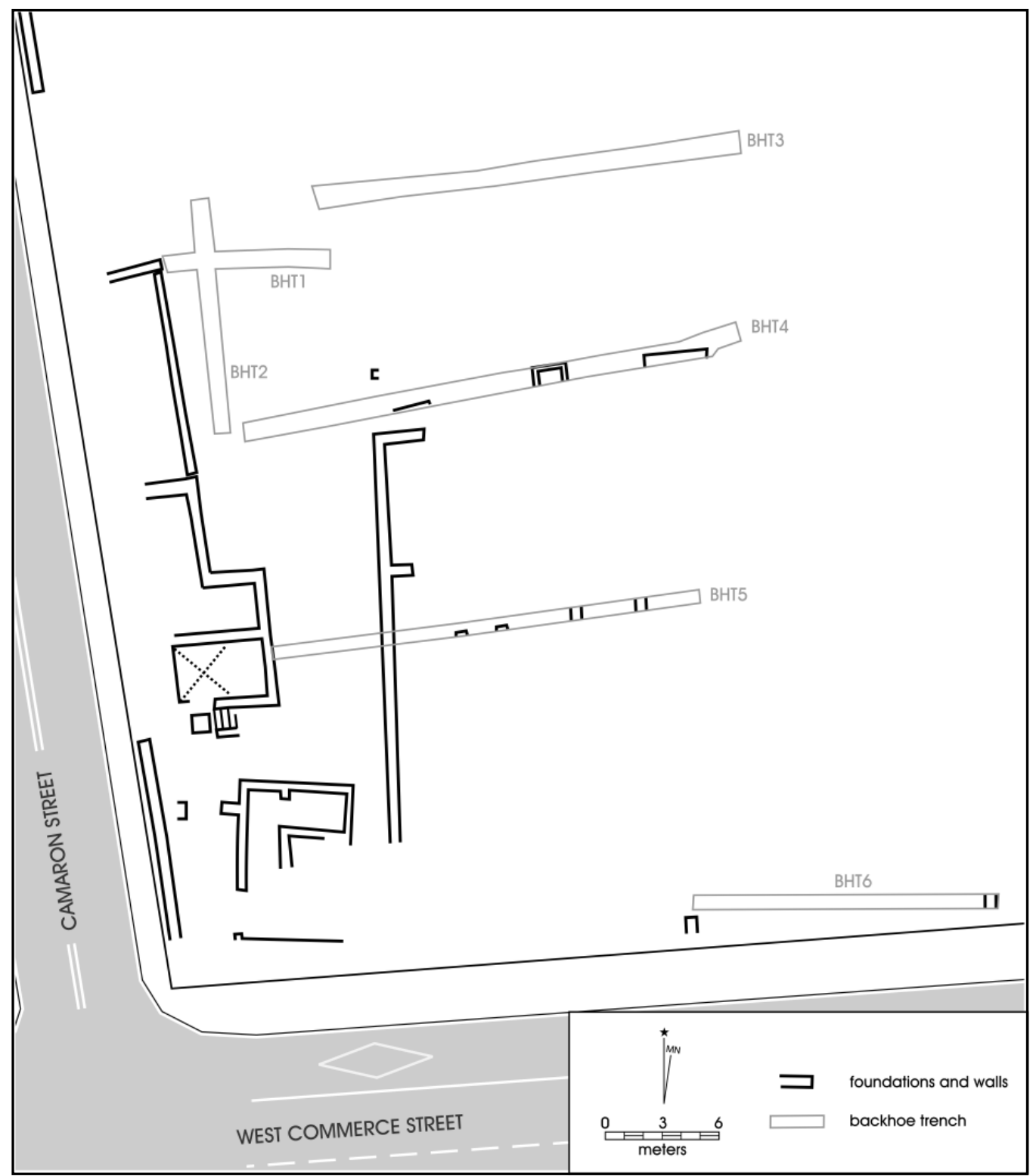

Figure 8-1. Wall and foundation segments uncovered during archaeological investigations.

approximately $35 \mathrm{cmbs}$. It contained heavy charcoal, metal andbone. No items were collected from this feature, and while the date of the pit is not known, the nature of the material clearly suggests that it was post-Colonial in age.

BHT 5 contained Pit 6 , described as a bottle cache, located at roughly $50 \mathrm{cmbs}$. Included in the small feature were a variety of English white earthenwares, two types of dark glass that appear to be the remains of wine bottles, unidentified metal strapping, flat window glass, and one piece of olive glass that had an applied lip. The pit also contained plaster and charcoal. Some material within the pit may date prior to 1860 . Finally, at the western edge of the trench, a second midden deposit (Midden 2) was uncovered in the southern wall. This southern midden, which contained large quantities of bone and Colonial ceramics, will be discussed at the end of this chapter. 


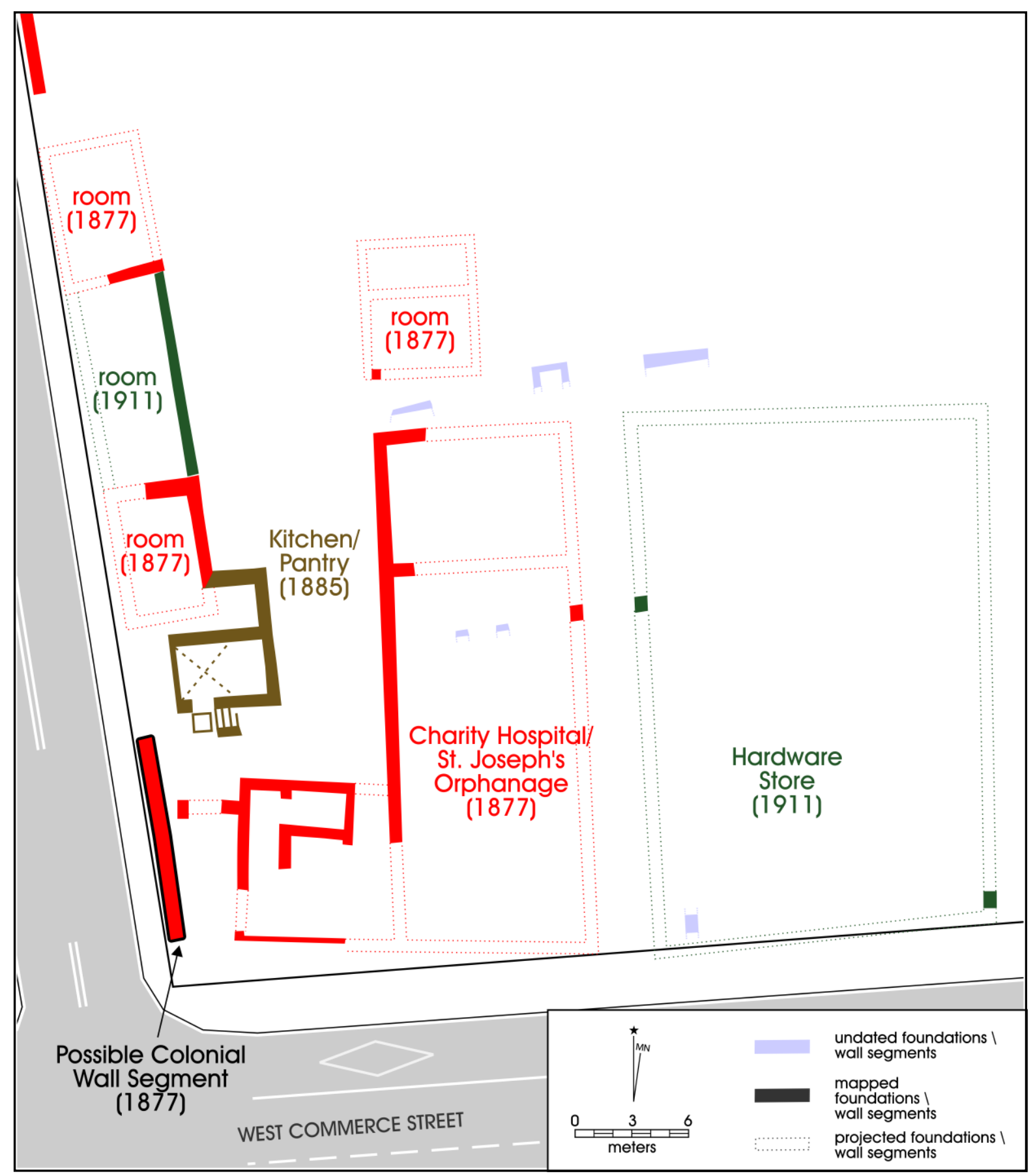

Figure 8-2. Probable correspondence between recorded wall alignments and archival maps. 


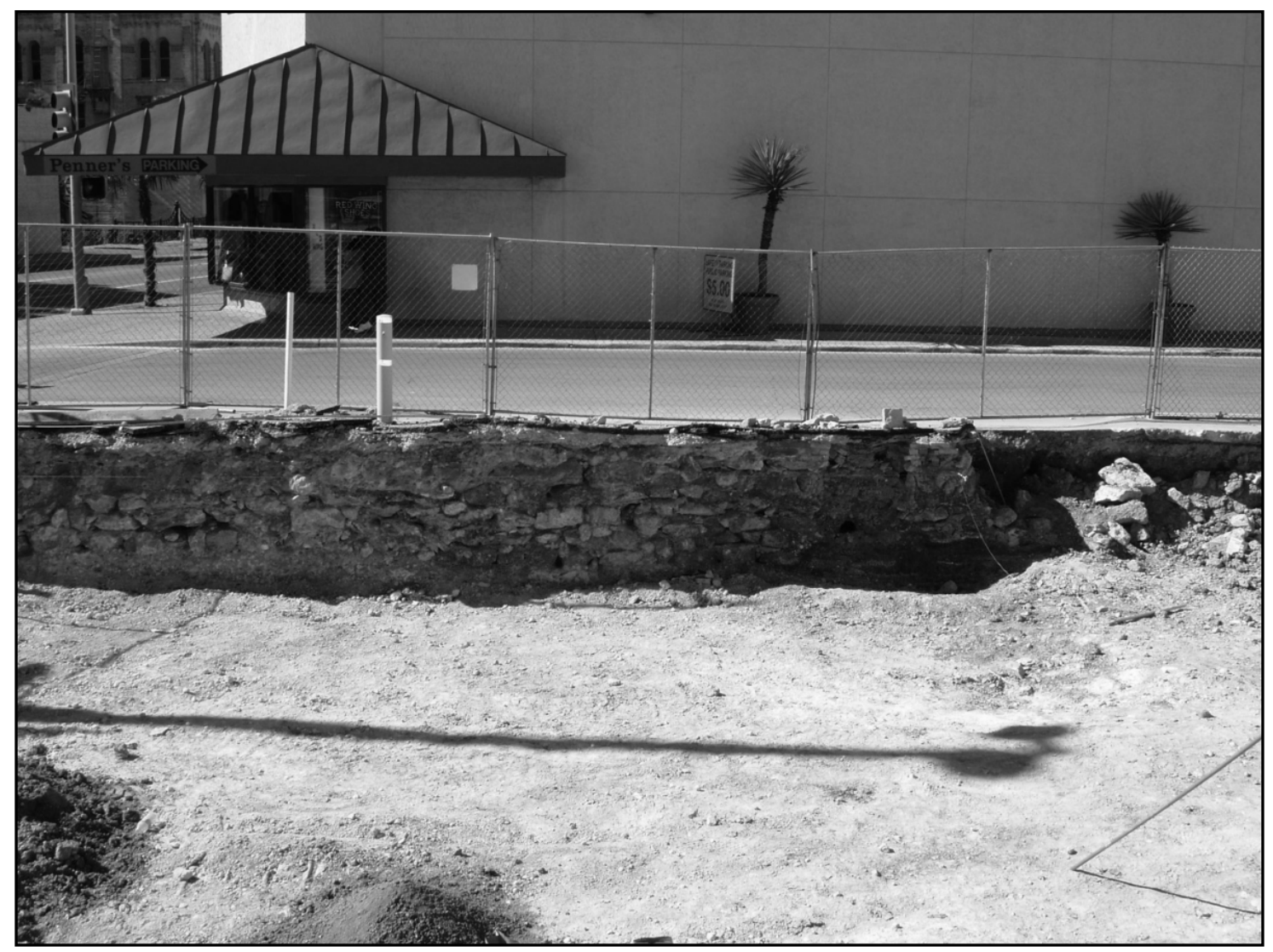

Figure 8-3. Overview of possible Colonial-period wall segment paralleling Carmaron Street.

\section{The Northern Midden (Midden 1)}

As discussed in Chapter 6, the northern midden at 41BX1598, originally seen in the southern wall of the CPS vault excavation, was initially explored through mechanical stripping and shovel testing. Following this initial effort, additional stripping was performed. Two backhoe trenches (BHTs 1 and 2), and four 1-x-1-m excavation units were then placed in the deposits.

The midden appeared, based on profiles in BHTs 1 and 2 and the face of the CPS vault excavation, to have been roughly oval in plan view, and formed a deep basin in cross-section (Figure 8-7). If the slightly oval outline is accurate, then the midden was approximately $9 \mathrm{~m}$ east-west and $10 \mathrm{~m}$ north-south, and covered a surface area of $71 \mathrm{~m}^{2}$. The thickness of the midden deposit was variable. In BHT 1, the maximum thickness of the midden, occurring in the western edge of the trench and discounting the modern material, was about $1.0 \mathrm{~m}$. The midden deposits in Unit 4, which was located in the approximate center of the feature, began at about $1.66 \mathrm{~m}$ below asphalt, and terminated at roughly $2.64 \mathrm{~m}$ for a thickness of $98 \mathrm{~cm}$. The midden in Unit 5 began at about $1.65 \mathrm{~m}$ below asphalt, and terminated at $2.26 \mathrm{~m}$ for a thickness of $0.61 \mathrm{~cm}$. In Unit 2, the midden deposits were clearly identified at $1.43 \mathrm{~m}$ below asphalt, and terminated at $2.03 \mathrm{~m}(0.60 \mathrm{~cm})$ and in Unit 1 the deposits began at $1.34 \mathrm{~m}$ and terminated at $1.99 \mathrm{~m}$ below asphalt $(0.65 \mathrm{~cm})$. As discussed in Chapter 6 , shovel testing suggested that midden deposits may have been encountered as high as $1.30 \mathrm{~m}$ below asphalt in some locations (see Figure 6-1). If that determination is accurate, then the mechanical stripping done after the shovel testing may have removed a small portion of the upper deposits in the feature. Nevertheless, using the thickness and area estimates presented above, along with the basin-shaped cross-section, we estimate that the feature may have contained at least $53 \mathrm{~m}^{3}$ of deposit, of which we systematically sampled $2.84 \mathrm{~m}^{3}$ (ca. $5 \%$ ). 


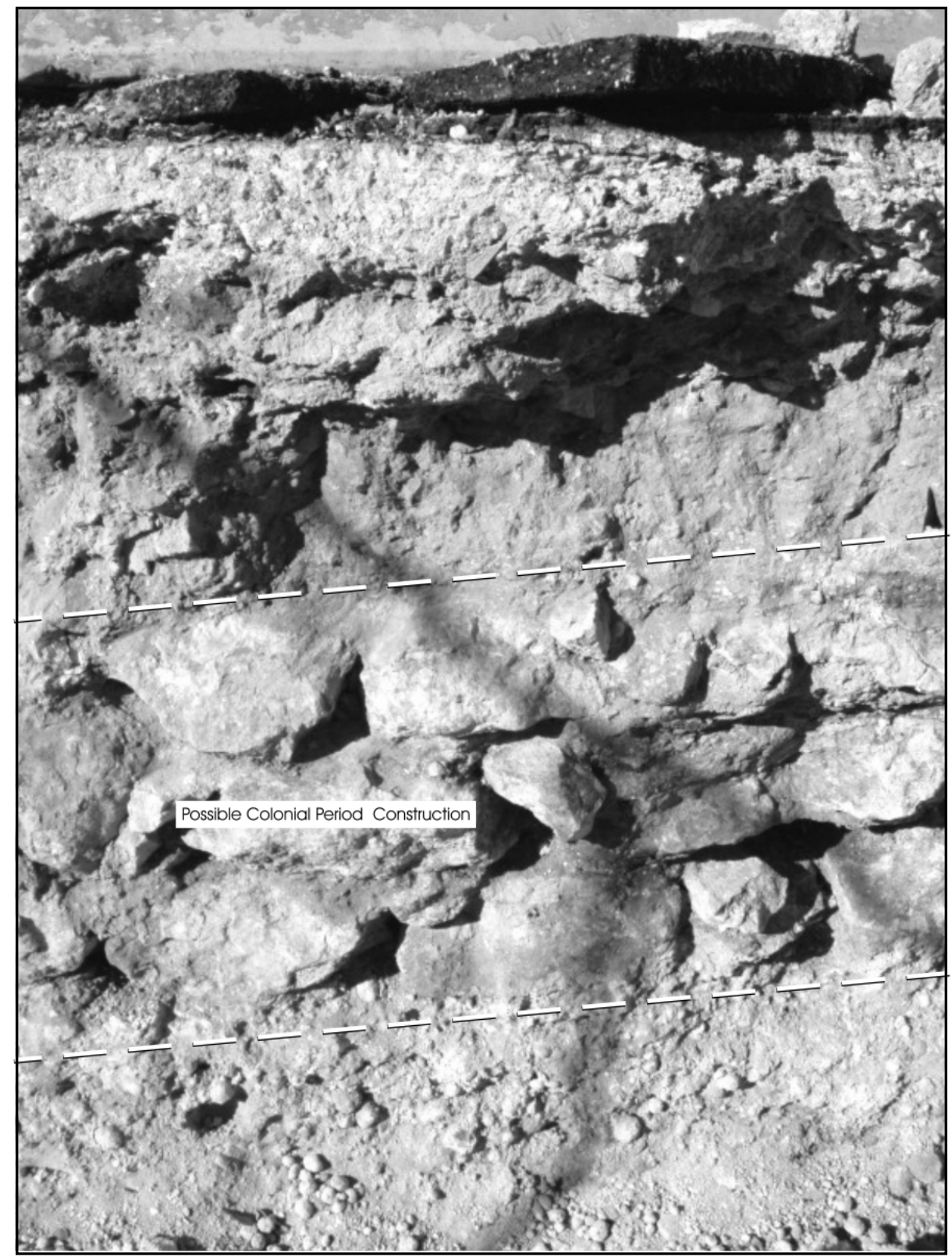

Figure 8-4. Possible Colonial-period wall foundation in the southwestern portion of the project area.

As noted in Chapter 6, the deposits within this midden consisted of several distinct zones, which are outlined in Figure 8-7. The zones varied both in their sediment composition, color, and artifact content. An examination of Figure 8-7 shows that they varied in thickness across the trench profile, and that not all of the zones were continuous across the midden. For example, Zones 1, 2, and 3 truncated towards the east, and all three of these zones were not present in the eastern end of the profile. These zones were not water- or wind-deposited, and appeared to represent either distinct periods of trash disposal or distinct sources of trash disposal. While the zones were used in the excavations of Units 4 and 5, they were only identified after the backhoe trenches were cut. Consequently, they were not recognized in the initial excavations conducted in Units 1 and 2. 


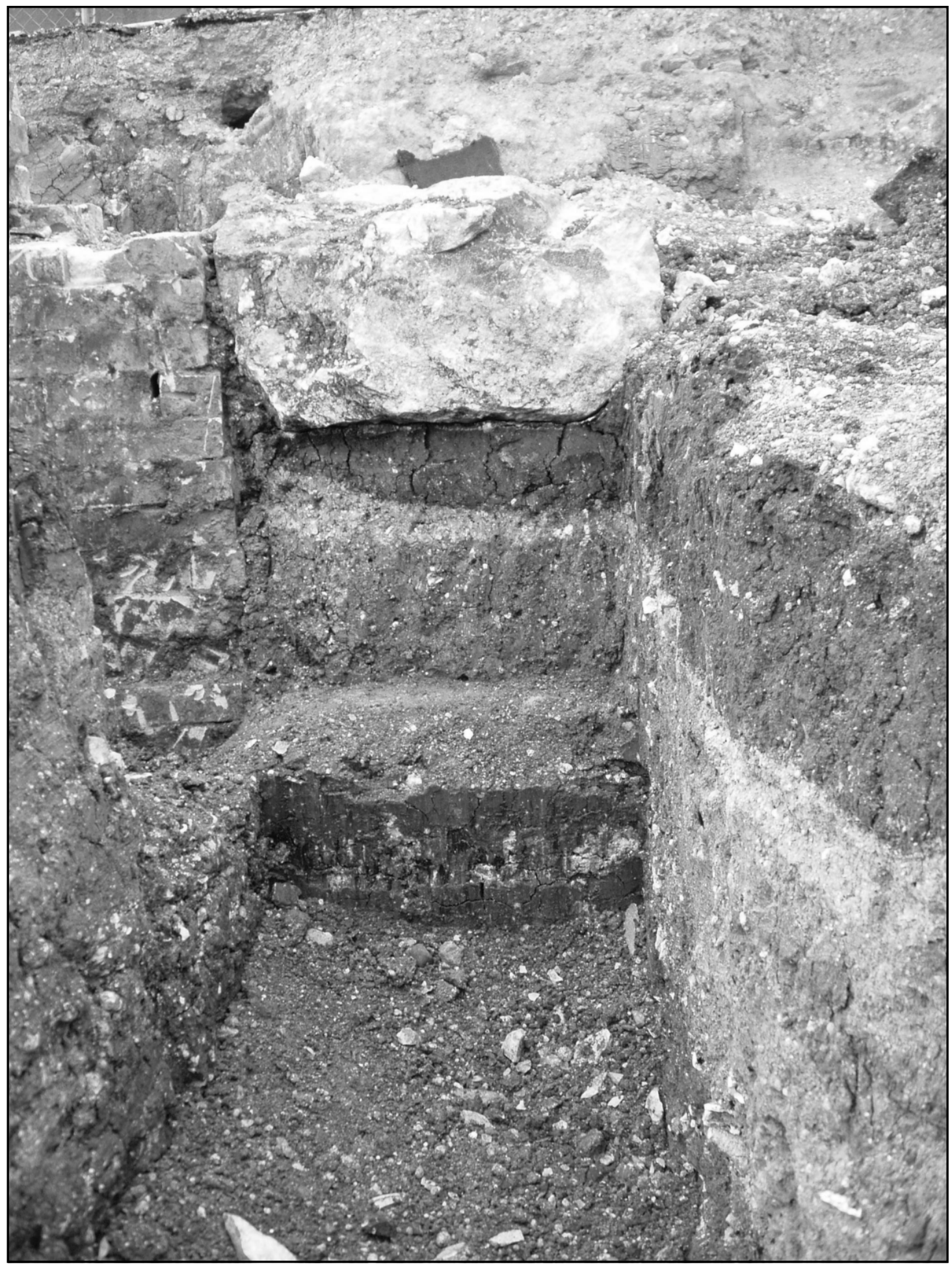

Figure 8-5. Wall foundations in the area of Midden 1(northern midden). Note midden continuing under wall. 


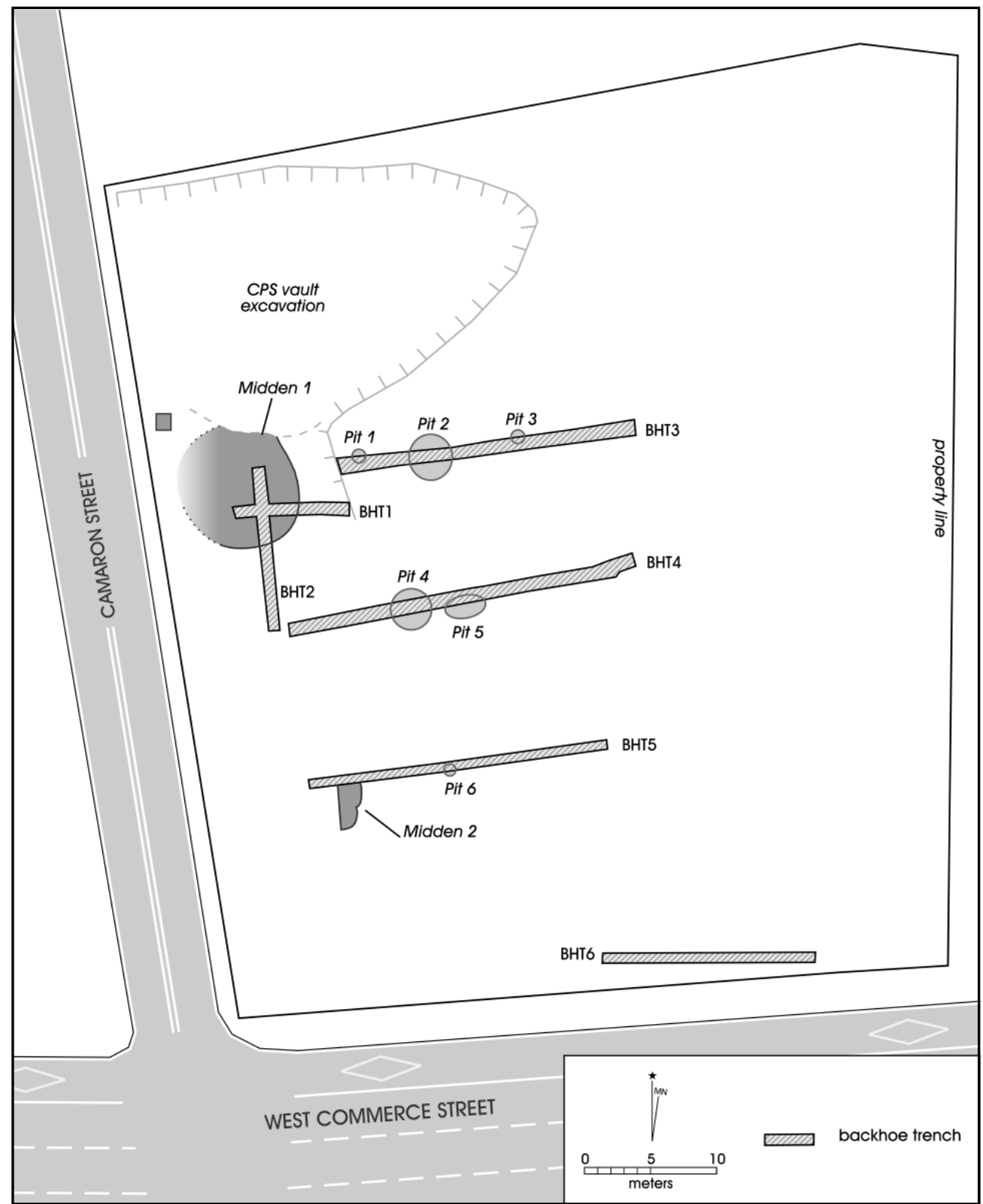

Figure 8-6. Locations of pit features (nos. 1-6) and middens at 41BX1598.

The variable nature and thickness of the depositional zones present in the midden result in dramatic differences in content between the units; this can be seen in Table 8-1. The table provides volume-corrected (per cubic meter) figures for major artifact classes and bone recovery from levels identified as being within the midden for Units 1, 2, 4 , and 5, along with an overall average recovery density. Unit 4, located near the center of the feature, had the highest density of the four units, with 4,459 items per cubic meter of fill. Density in the northern portion of the feature, reflected by Unit 1 recovery, is substantially lower, with only 2,145 items recovered per cubic meter of sediment. Near the margins of the feature, the density also seems to decline relative to the feature center. This is reflected in Unit 2, with an overall density of 3,578 items per cubic meter of midden deposit. If our volume estimates are close to reality, 


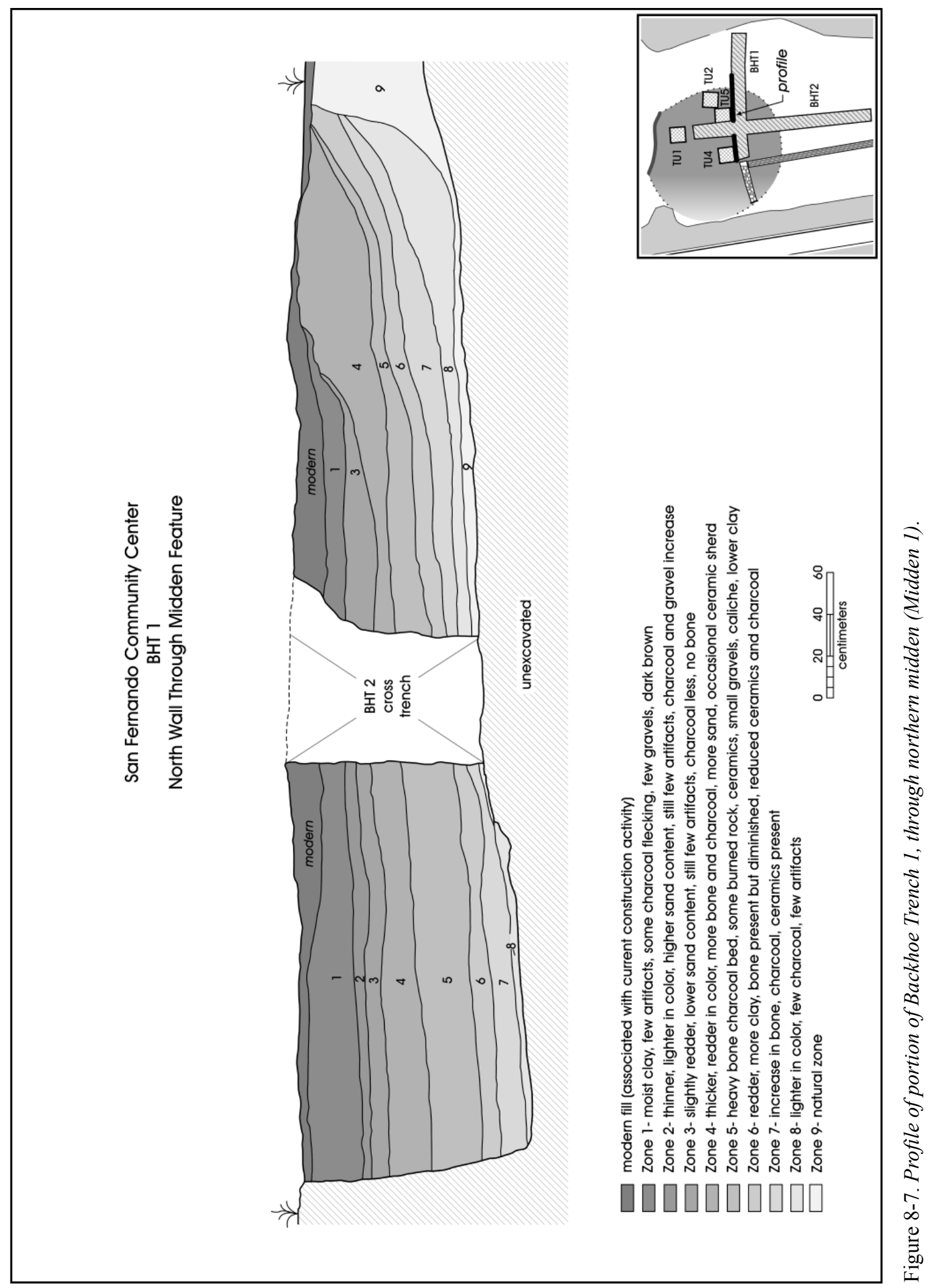


and assuming that the average recovery is reflected across the midden, then the feature as a whole contained roughly 2,173 Native American sherds, about 13,750 Spanish Colonial ceramics, 2,875 English ceramics, 3,577 pieces of debitage, almost 80 gunflints, and over 660 kilograms of bone.

While much of the variation in the total number of items between units shown in Table 8-1 is primarily accounted for by differences in the number of bones recovered, there are also differences in non-bone counts between units. Ceramics, for example, account for roughly $53 \%$ and $54 \%$ of the non-bone artifacts in Units 1 and 2, respectively, $60 \%$ in Unit 4 , and almost $69 \%$ in Unit 5. Table $8-2$ presents the results of a chi-square test, along with the adjusted standardized residuals, for the number of ceramics by origin for the four units within the midden that highlight additional horizontal differences. As discussed by several authors (see Everitt 1977; Haberman 1973), adjusted residuals provide information on the contribution of each individual cell to the overall significance of a contingency table. They are analogous to Z-scores, such that an adjusted residual value exceeding an absolute value of 1.96 suggests that the cell differences are statistically significant at a probability beyond the .05 level. The overall chi-square value is significant. This suggests that the overall distribution of ceramics by origin (i.e., Native American, Spanish Colonial, and English) is significantly different between the units. An examination of the standardized adjusted residuals suggests that English wares are dramatically over-represented in Unit 1, located to the north (adjusted residual $=5.13$ ), while both Spanish Colonial (-2.18) and Native American (-2.75) sherds are under-represented. Unit 2 has a statistically significant over-representation of Spanish Colonial wares, and an under-representation of English wares. Finally, Spanish Colonial wares are under-represented in Unit 4, though this difference is not statistically significant. These horizontal differences across the midden are consistent with a series of individual dumping events and low levels of post-depositional mixing of the deposits.

Given the horizontal differences noted above, it is not surprising that vertical differences in artifacts within the deposit are also present. Figure 8-8 presents total counts of all recovered items, including bone, for Units 4 and 5, by depositional zone. Note that these counts have been standardized by sediment volume. The overall graph, then, can be seen as a measure of the intensity of use of this central portion of the midden. The pattern suggests that Zones 7, 5, 4, and to a lesser extent Zone 2, were periods of intensive use, while Zones 6, 3, and 1 reflect lower deposition rates. Note also that while depositional rates fluctuate, the overall pattern is declining through time, especially above Zone 4 .

Table 8-1. Artifact Densities for Units Excavated in Midden 1 (northern midden)

\begin{tabular}{|c|c|c|c|c|c|c|c|c|c|c|c|c|c|c|c|c|}
\hline Units & 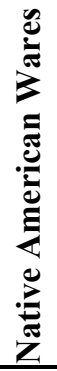 & 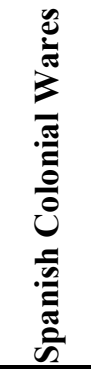 & 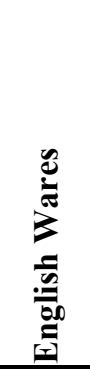 & $\frac{\tilde{\sigma}}{0}$ & 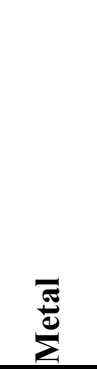 & $\stackrel{\mathscr{E}}{\stackrel{0}{E}}$ & 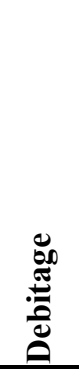 & 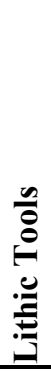 & $\stackrel{\stackrel{\Xi}{\Xi}}{:}$ & $\begin{array}{l}\frac{0}{0} \\
\stackrel{0}{0} \\
\stackrel{0}{0} \\
\stackrel{0}{0}\end{array}$ & 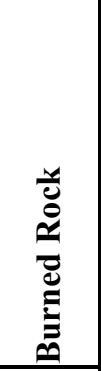 & 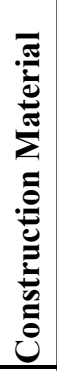 & 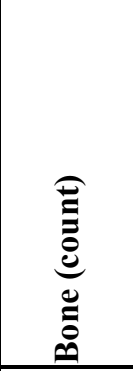 & 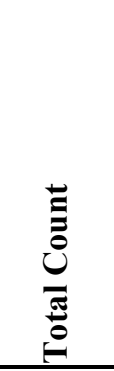 & 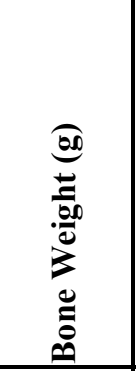 & 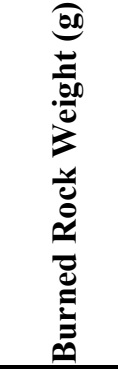 \\
\hline 1 & 14 & 152 & 60 & 18 & 12 & 2 & 55 & 2 & 2 & 2 & 102 & 4 & 1719 & 2145 & 3276 & 1120 \\
\hline 2 & 38 & 273 & 33 & 17 & 72 & 0 & 65 & 2 & 0 & 0 & 137 & 0 & 2942 & 3578 & 10210 & 2310 \\
\hline 4 & 42 & 203 & 50 & 19 & 41 & 3 & 65 & 3 & 1 & 1 & 49 & 13 & 3973 & 4459 & 17184 & 592 \\
\hline 5 & 70 & 410 & 74 & 25 & 44 & 3 & 85 & 5 & 3 & 2 & 79 & 3 & 3373 & 4176 & 19360 & 539 \\
\hline Average & 41 & 259.5 & 54.25 & 19.75 & 42.25 & 2 & 67.5 & 3 & 1.5 & 1.25 & 91.75 & 5 & 3001.75 & 3589.5 & 12507.5 & 1140.25 \\
\hline
\end{tabular}


Table 8-2. Observed Ceramic Counts and Adjusted Residuals for Units 1,2,4, and 5 (Midden 1)

\begin{tabular}{|c|l|c|c|c|c|}
\hline \multicolumn{2}{|c|}{} & \multicolumn{3}{|c|}{ Ceramic Groups } & \\
\hline \multirow{2}{*}{ Units } & & $\begin{array}{c}\text { Native } \\
\text { American }\end{array}$ & Spanish & English & Total \\
\hline 1 & Count & 14 & 152 & 60 & 226 \\
& Adjusted Residual & -2.75 & -2.18 & 5.13 & \\
\hline 2 & Count & 38 & 273 & 33 & 344 \\
& Adjusted Residual & -0.34 & 2.99 & -3.37 & \\
\hline 4 & Count & 42 & 203 & 50 & 295 \\
& Adjusted Residual & 1.62 & -1.89 & 0.89 & \\
\hline 5 & Count & 70 & 410 & 74 & 554 \\
& Adjusted Residual & 1.02 & 0.58 & -1.62 & \\
\hline Total & Count & 164 & 1038 & 217 & 1419 \\
\hline
\end{tabular}

$\mathrm{X}^{2}=39.71$

Degrees of freedom $=6$

Probability $<.001$

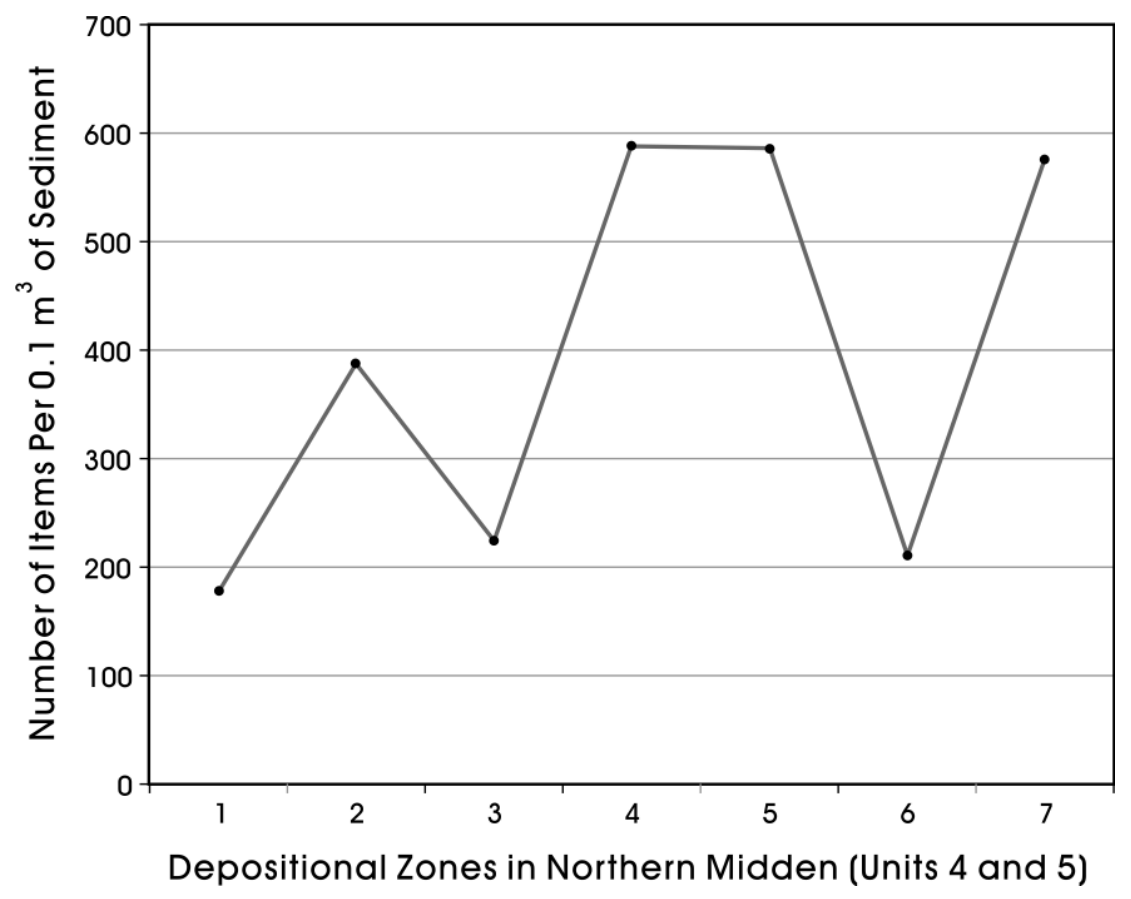

Figure 8-8. Line graph of number of items per $0.1 \mathrm{~m}^{3}$ of sediment for depositional zones in northern midden (Midden 1). 
These declining depositional rates can be seen more clearly in Figure 8-9, which presents bone weight corrected for sediment volume for Units 4 and 5 by depositional zone. Bone weight is clearly highest in Zones 7 and 5, with a fairly steady decline in the more recent zones. These data suggest that the most intensive period of use for this midden was early in its formation, with lower use intensity later in time. Bison was recovered from both Zones $5(\mathrm{n}=8)$ and $7(\mathrm{n}=13)$, with Zone 7 also containing both pieces of antelope recovered from the site. Domesticated species were also present in these high-density zones, with cattle being the dominate animal identified in both zones.

Finally, we turn to issues related to establishing when this midden feature formed. We can begin this by looking at the vertical distribution of Colonial ceramics, including the Native American Goliad ceramics, relative to English ceramics, within each of the four units placed within this feature. Table 8-3 presents the chi-square results for Unit 1. The overall chi-square is not significant, and only two of the cells, those for Level 8, approach significance at the .05 level where Colonial ceramics account for all nine sherds present. A similar result is present for Unit 2 (Table 8-4) which has a non-significant chi-square for the overall table and no cells with significant adjusted residuals. In both of these units, then, there is no increase in Colonial relative to English ceramics with increasing depth. Table 8-5 presents the results for Unit 4, using the zones rather than individual levels. Once again, the overall chi-square is not significant and there are no cells that have significant adjusted residuals. However, examination of the individual cells in Table 8-5 shows that Colonial ceramics are over-represented in the bottom three zones within the midden (Zones 5, 6, and 7), though none of the cells are significant. This trend is consistent with a slight, though not statistically significant, over-representation of Colonial relative to English ceramics with increasing depth. Finally, Table 8-6 presents the results for Unit 5. The chi-square results for this contingency table are significant, and the adjusted residual data show that eight of the 12 cells make a significant contribution to the overall

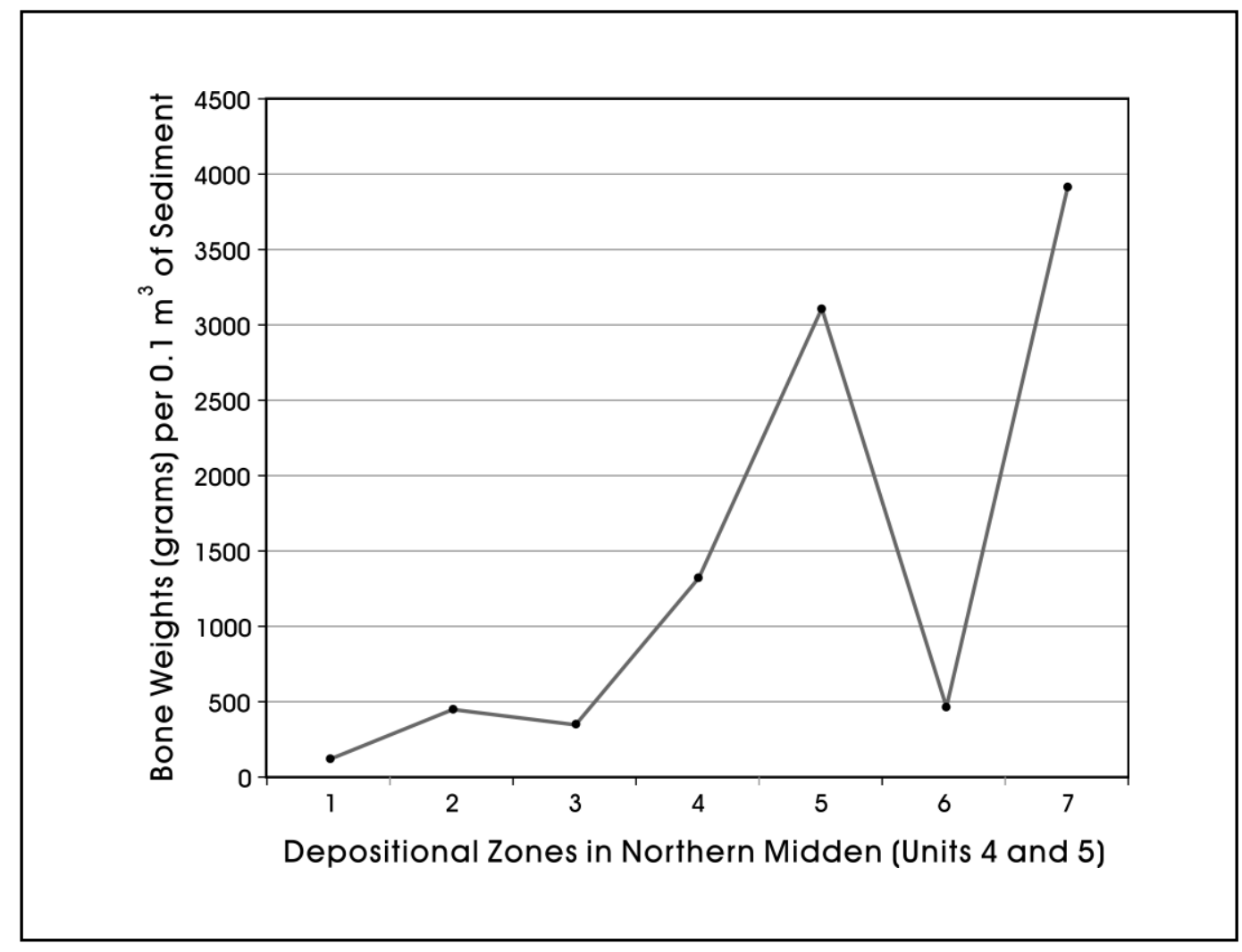

Figure 8-9. Line graph of bone weight per $0.1 \mathrm{~m}^{3}$ of sediment for depositional zones in northern midden (Midden 1). 
Table 8-3. Observed Colonial and English Ceramic Counts and Adjusted Residuals for Unit 1

\begin{tabular}{|c|c|c|c|c|}
\hline \multirow[b]{2}{*}{ Level } & & Ceramic & Groups & \multirow[t]{2}{*}{ Total } \\
\hline & & Colonial & English & \\
\hline 3 & $\begin{array}{l}\text { Count } \\
\text { Adjusted Residual }\end{array}$ & $\begin{array}{c}13 \\
-0.453\end{array}$ & $\begin{array}{c}6 \\
0.453\end{array}$ & 19 \\
\hline 4 & $\begin{array}{l}\text { Count } \\
\text { Adjusted Residual }\end{array}$ & $\begin{array}{c}20 \\
-1.474\end{array}$ & $\begin{array}{c}12 \\
1.474\end{array}$ & 32 \\
\hline 5 & $\begin{array}{l}\text { Count } \\
\text { Adjusted Residual }\end{array}$ & $\begin{array}{c}25 \\
0.446\end{array}$ & $\begin{array}{c}8 \\
-0.446\end{array}$ & 33 \\
\hline 6 & $\begin{array}{l}\text { Count } \\
\text { Adjusted Residual }\end{array}$ & $\begin{array}{c}23 \\
0.892\end{array}$ & $\begin{array}{c}6 \\
-0.892\end{array}$ & 29 \\
\hline 7 & $\begin{array}{l}\text { Count } \\
\text { Adjusted Residual }\end{array}$ & $\begin{array}{c}14 \\
-0.675\end{array}$ & $\begin{array}{c}7 \\
0.675\end{array}$ & 21 \\
\hline 8 & $\begin{array}{l}\text { Count } \\
\text { Adjusted Residual }\end{array}$ & $\begin{array}{c}9 \\
1.898\end{array}$ & $\begin{array}{c}0 \\
-1.898\end{array}$ & 9 \\
\hline Total & Count & 104 & 39 & 143 \\
\hline
\end{tabular}

$\mathrm{X}^{2}=6.415$

Degrees of freedom $=5$

Probability $=.288$

Table 8-4. Observed Colonial and English Ceramic Counts and Adjusted Residuals for Unit 2

\begin{tabular}{|c|l|c|c|c|}
\hline \multirow{2}{*}{ Level } & & Ceramic & Groups & \multirow{2}{*}{ Total } \\
\cline { 3 - 4 } 2 & & Colonial & English & Count \\
\cline { 3 - 4 } & Adjusted Residual & 87 & 8 & 95 \\
\hline 3 & Count & 41 & -0.557 & \\
\hline 4 & Adjusted Residual & 0.198 & -0.198 & 45 \\
\hline 5 & Count & 30 & 4 & 34 \\
& Adjusted Residual & -0.454 & 0.454 & \\
\hline 5 & Count & 20 & 3 & 23 \\
& Adjusted Residual & -0.582 & 0.582 & \\
\hline 6 & Count & 4 & 1 & 5 \\
& Adjusted Residual & -0.792 & 0.792 & \\
\hline 7 & Count & 5 & 0 & 5 \\
& Adjusted Residual & 0.740 & -0.740 & \\
\hline Total & Count & 187 & 20 & 207 \\
\hline
\end{tabular}

$\mathrm{X}^{2}=1.819$

Degrees of freedom $=5$

Probability $=.874$ 
Table 8-5. Observed Colonial and English Ceramic Counts and Adjusted Residuals for Unit 4

\begin{tabular}{|c|l|c|c|c|}
\hline \multirow{2}{*}{ Zones } & & Ceramic & Groups & \multirow{2}{*}{ Total } \\
\cline { 3 - 4 } & & Colonial & English & 2 \\
& Count & 2 & 0 & 2 \\
& Adjusted Residual & 0.680 & -0.680 & \\
\hline 2 & Count & 38 & 12 & 50 \\
& Adjusted Residual & -1.141 & 1.141 & \\
\hline 3 & Count & 15 & 4 & 19 \\
& Adjusted Residual & -0.288 & 0.288 & \\
\hline 4 & Count & 61 & 15 & 76 \\
& Adjusted Residual & -0.325 & 0.325 & \\
\hline 5 & Count & 26 & 3 & 29 \\
& Adjusted Residual & 1.244 & -1.244 & \\
\hline 6 & Count & 2 & 0 & 2 \\
& Adjusted Residual & 0.680 & -0.680 & \\
\hline 7 & Count & 9 & 1 & 10 \\
& Adjusted Residual & 0.719 & -0.719 & \\
\hline Total & Count & 153 & 35 & 188 \\
\hline
\end{tabular}

$\mathrm{X}^{2}=3.808$

Degrees of freedom $=5$

Probability $=.703$

chi-square values. The patterns within the zones, however, do not make chronological sense. While Colonial ceramics are under-represented relative to English ceramics in Zone 3, near the top of the midden, they are also significantly under-represented in Zone 7, the bottom of the midden. The contingency table analysis, then, suggests that there is little or no chronological patterning in ceramics when we compare Colonial and English wares. This is surprising, especially given the clear depositional zones reflected in Units 4 and 5.

A variety of specific ceramics types dating to as early as 1650 and as late as 1910 were present in the midden deposit and can provide a more detailed look at midden formation. Figure 8-10 shows the number of sherds by type for those types that have estimated age ranges. Clearly, the three dominant types all terminate before 1850 , and the latest beginning date for these three types is 1725 . Using these three types, then, the deposits in the midden were formed sometime between 1725 and 1850 , although ceramic types are present that date to as late as the early twentieth century (Figure 8-10). A termination date of sometime before the late 1860s, when the archival records suggest that the hospital was constructed over the midden location, is consistent with the ceramic assemblage present in the feature. A closer examination of the vertical distribution of these types within the midden deposit supports aspects of the 1725 to 1850 age range for the midden formation, since two Spanish Colonial Galera sherds were recovered from Zone 8, a deposit just under the main midden deposit. This ware is provisionally dated to between 1725 and 1850 , further suggesting that the midden began forming sometime after 1725 .

The distribution of the ceramic types, when considered in more detail, also calls into question aspects of the ceramic age ranges suggested earlier. Using the zone data from Units 4 and 5 , for example, Goliad ware, with a termination date of around 1800, was present in all zones. Also present with Goliad ware in Zones 2, 3, 4, and 5 were annular/banded slip English whitewares, with a beginning date of 1825 . These two types should not overlap in any zone, yet they co-occurred in four zones in the heart of the midden. Given that no temporal trends were revealed in the adjusted residual 
Table 8-6. Observed Colonial and English Ceramic Counts and Adjusted Residuals for Unit 5

\begin{tabular}{|c|l|cc|c|}
\hline \multirow{2}{*}{ Zone } & & Ceramic & Groups & \multirow{2}{*}{ Total } \\
\cline { 3 - 4 } 1 & & Colonial & English & Tount \\
\cline { 2 - 3 } & Adjusted Residual & -0.084 & 0.084 & 26 \\
\hline 3 & Count & 66 & 21 & 87 \\
& Adjusted Residual & -2.869 & 2.869 & \\
\hline 4 & Count & 75 & 6 & 81 \\
& Adjusted Residual & 2.178 & -2.178 & \\
\hline 5 & Count & 80 & 7 & 87 \\
& Adjusted Residual & 2.089 & -2.089 & \\
\hline 6 & Count & 9 & 1 & 10 \\
& Adjusted Residual & 0.436 & -0.436 & \\
\hline 7 & Count & 18 & 8 & 26 \\
& Adjusted Residual & -2.388 & 2.388 & \\
\hline Total & Count & 270 & 47 & 317 \\
\hline
\end{tabular}

$\mathrm{X}^{2}=18.095$

Degrees of freedom $=5$

Probability $=.003$

analysis, at least in terms of Colonial wares relative to English wares, and given that types that do not overlap temporally were present in the same depositional zones, it is tempting to suggest that the there had been substantial disturbance of the midden deposit. However, at least in the case of Units 4 and 5 , there were clearly defined depositional zones present in the midden. The zones were easily identified, with no breaks revealed in the profile. While in several cases the zones were not continuous, there was roughly $50 \mathrm{~cm}$ of vertical separation between the top of Zone 2 and the bottom of Zone 5, where Goliad wares overlapped with annular/banded slip English whitewares. Assuming that the types have been correctly identified, it is probable that what we think we know about the age ranges, at least for some ceramic types, may not be correct.

It is possible, for instance, that Goliad wares may have continued to be manufactured past 1800 or perhaps some English wares, specifically annular/banded slip wares, may have come into use somewhat earlier that previously thought. While larger sample sizes from well-stratified deposits will be necessary to clearly establish specific date ranges for the
San Antonio area, it is likely that either Goliad ware was present much later than 1800, or English annular/banded slip and whitewares came into the area earlier than 1825 (see also Fox 1992:46).

\section{Summary}

The northern-most midden at 41BX1598 was one of the principal features uncovered at the site. The midden was a deep basin, and seemed to reflect the deposition of what was primarily domestic trash. At least in some portion of the midden deposit, trash deposition was clearly visible as a series of distinct sediment zones. Ceramics suggest that the midden probably formed sometime between 1725 and the early 1900 s, though the midden was capped by construction in the late 1860s. The feature was substantial in size, and if the 1-x-1-m units excavated into the feature were any indication of the overall density and variety of material, the feature may have contained a wide variety of artifacts and ecofacts, including over 660 kilograms of vertebrate fauna, over 3,500 pieces of debitage, about 


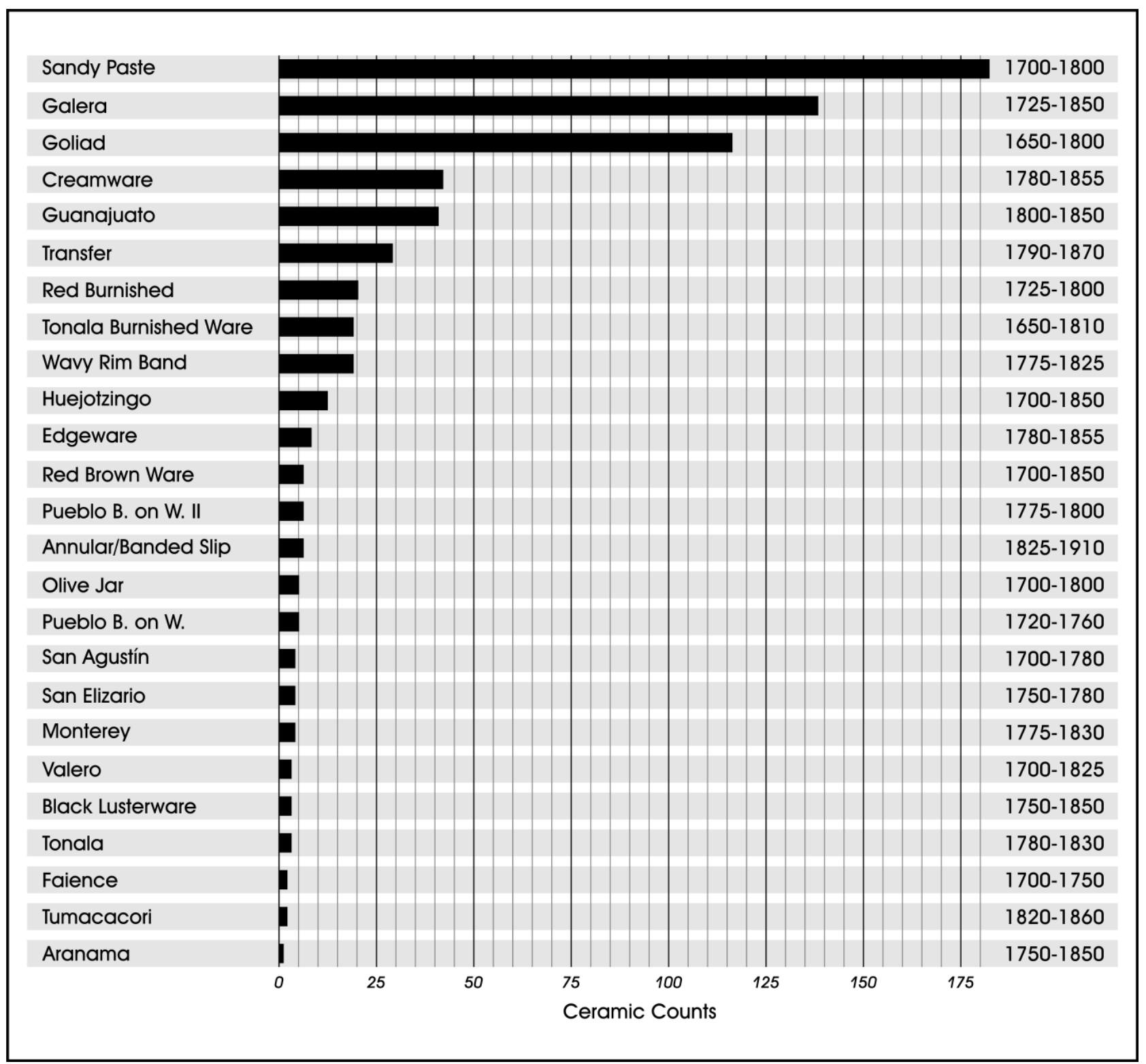

Figure 8-10. Dated ceramic types recovered in the northern midden (Midden 1).

80 gunflints, and over 18,000 ceramic sherds. Using either artifact numbers, or bone density, it appears that the intensity of midden use declined through time, especially after the formation of Zone 4. The faunal material recovered from the midden was dominated by unidentified mammal remains. Of those items that could be identified, a variety of domesticated and wild species were present, and while the deposits were dominated by cattle, several examples of bison and antelope were present in the lower levels of the deposit. Flotation analysis, discussed in the previous chapter (see Table 7-2; Appendix B) produced no non-local woods or cultigens. However, pecan shell and mesquite seeds were recovered from midden contexts. Finally, the presence of the stratified deposits within a portion of the midden allowed us to examine ceramic associations in these zones. While the overall number of ceramics recovered from any given zone was small, the association of Goliad wares with English annular/banded slip and whitewares in several zones suggests that the estimated temporal ranges for these types are not correct (see also Fox 1992:46). 


\section{The Southern Midden (Midden 2)}

As noted in Chapter 6, a second midden deposit, located on the southern portion of the project area, was encountered in the western end of BHT 5. Only a portion of this midden remained, the midden having been damaged by subsequent construction. However, two major depositional sequences were recognized in this midden (Figures 8-11 and 8-12; see also Figure 6-6). This feature was further defined by cutting a profile with a backhoe, and sampled by the excavation of two test units. Unit 6 was a $50-\mathrm{x}-50-\mathrm{cm}$ test unit placed in what appeared to be the center of the deposit, and Unit 7 was a 1-x-1-m test unit placed roughly $60 \mathrm{~cm}$ to the north of Unit 6. Unit 7 was excavated after the removal of about $65 \mathrm{~cm}$ of what appeared to be the upper depositional event. Figure 8-13 shows Unit 7 after excavation. The lower midden deposit is clearly visible in the southern wall of the unit. Note, however, that the upper midden deposit was also present within this excavation as can be seen in the eastern wall of the unit. These two deposits were not separated during the excavation, and consequently, the artifact samples recovered contain a mixture of the two depositional sequences in all levels. Our discussion of this midden, therefore, focuses only on Unit 6.

The volume of the upper midden deposit is not known, as portions were destroyed both by BHT 5 and by the construction of the hospital. We can, however, provide a gross estimate on the volume of the lower deposit using the profile (see Figure 6-6), the results of the Unit 6 excavations, and the profile shown in the southern wall of Figure 8-12. The upper midden deposit was defined as being from Level 1 through Level 6, or roughly $1.15 \mathrm{~m}$ below asphalt to $2.04 \mathrm{~m}$ below asphalt. Between 2.04 and $2.08 \mathrm{~m}$ below

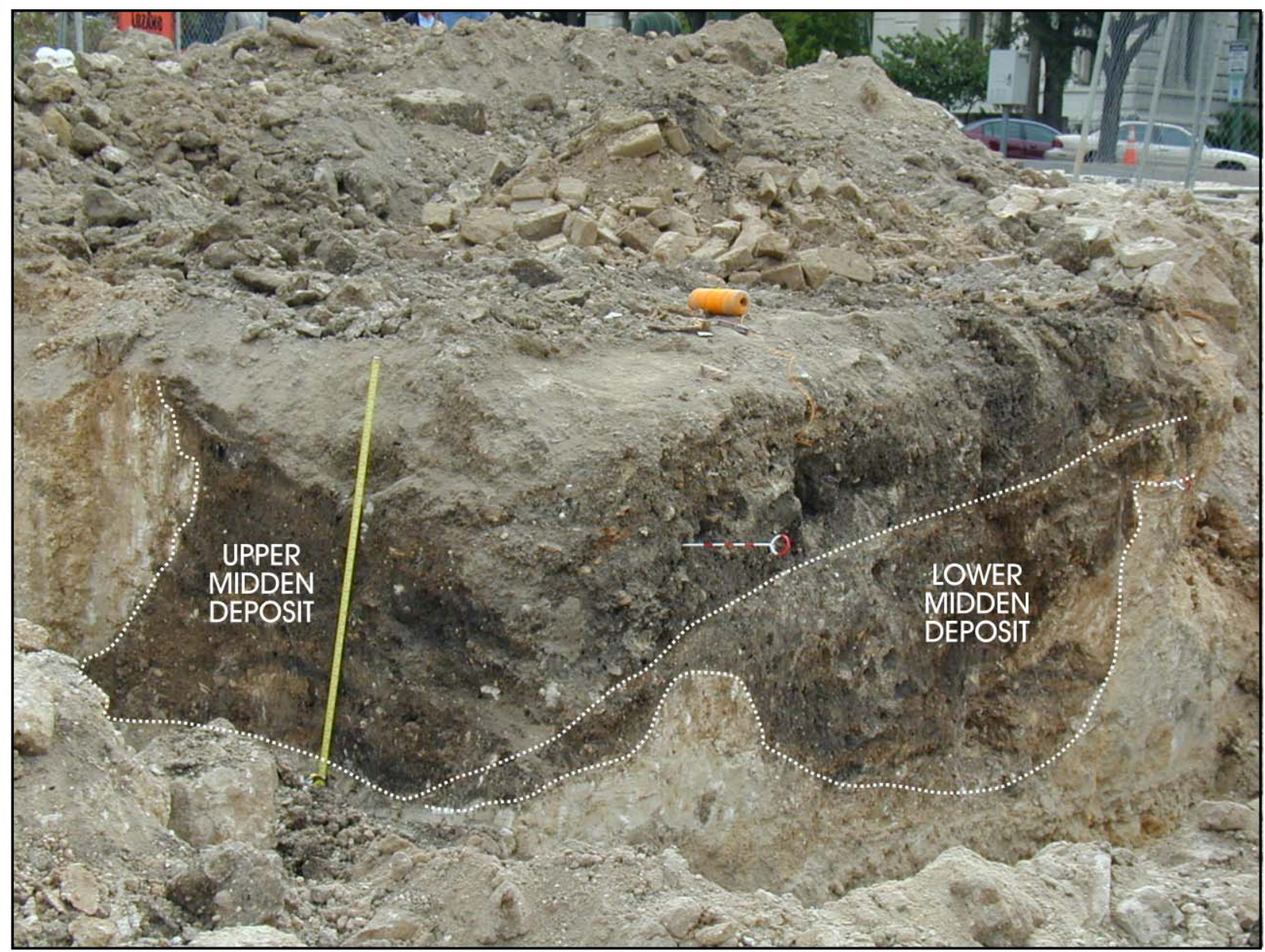

Figure 8-11. The southern midden (Midden 2) prior to excavation, with upper and lower deposits identified. 


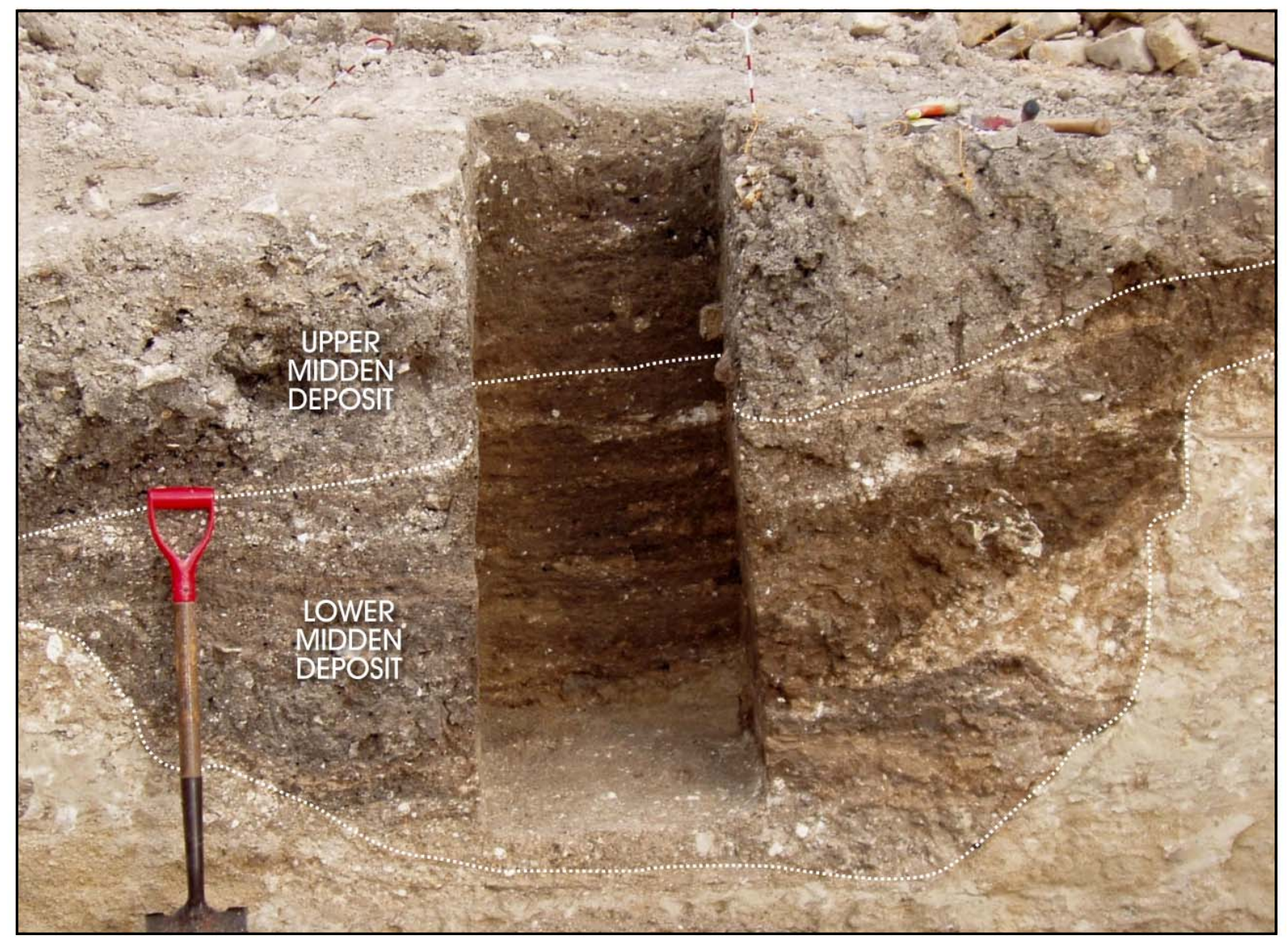

Figure 8-12. Unit 6 in Midden 2 (southern midden). Note depositional zones visible in back wall of unit.

asphalt, a sandy yellow layer, with only two items (a Spanish Colonial ceramic sherd and a single bone), was encountered. The lower midden deposit began at roughly $2.08 \mathrm{~m}$ below asphalt, and Unit 6 was through the deposit by Level 15 , about $2.78 \mathrm{~m}$ below asphalt. The feature, as shown in Figures 8-11 and 8-12 (see also Figure 6-6), was about $2.10 \mathrm{~m}$ across at the top, appeared to be roughly circular in plan view, and formed a deep basin in cross-section. Using these data, we can roughly estimate that the total volume of the lower midden deposit was $1.4 \mathrm{~m}^{3}$, of which Unit 6 sampled $0.175 \mathrm{~m}^{3}$, or roughly $12.5 \%$.

An examination of Figure 8-12 will show that there were several small lenses present in this midden, especially in the lower deposits. These lenses, for the most part, extended over only a short distance, unlike the zones of deposition identified in the northern midden deposit. However, like the zones identified in the northern midden, these lenses may well reflect relatively discrete dumping events. The fact that they could still be identified suggests that post-depositional disturbance of these deposits was limited.

Table 8-7 presents corrected volumetric estimates for major artifact classes from the upper and lower midden deposits in the southern midden. Northern midden totals are provided for comparison. The upper midden deposits in the southern midden are among the densest at the site. This midden had by far the highest bone density, and also had the highest densities of debitage, lithic tools, metal, glass, Spanish Colonial ceramics, and buttons. Conversely, densities in the lower midden deposit were much lower. This lower deposit, in fact, had the lowest densities among the three areas represented in the table in seven of the 11 artifact types presented. Only in two categories, gunflints and burned rock, 


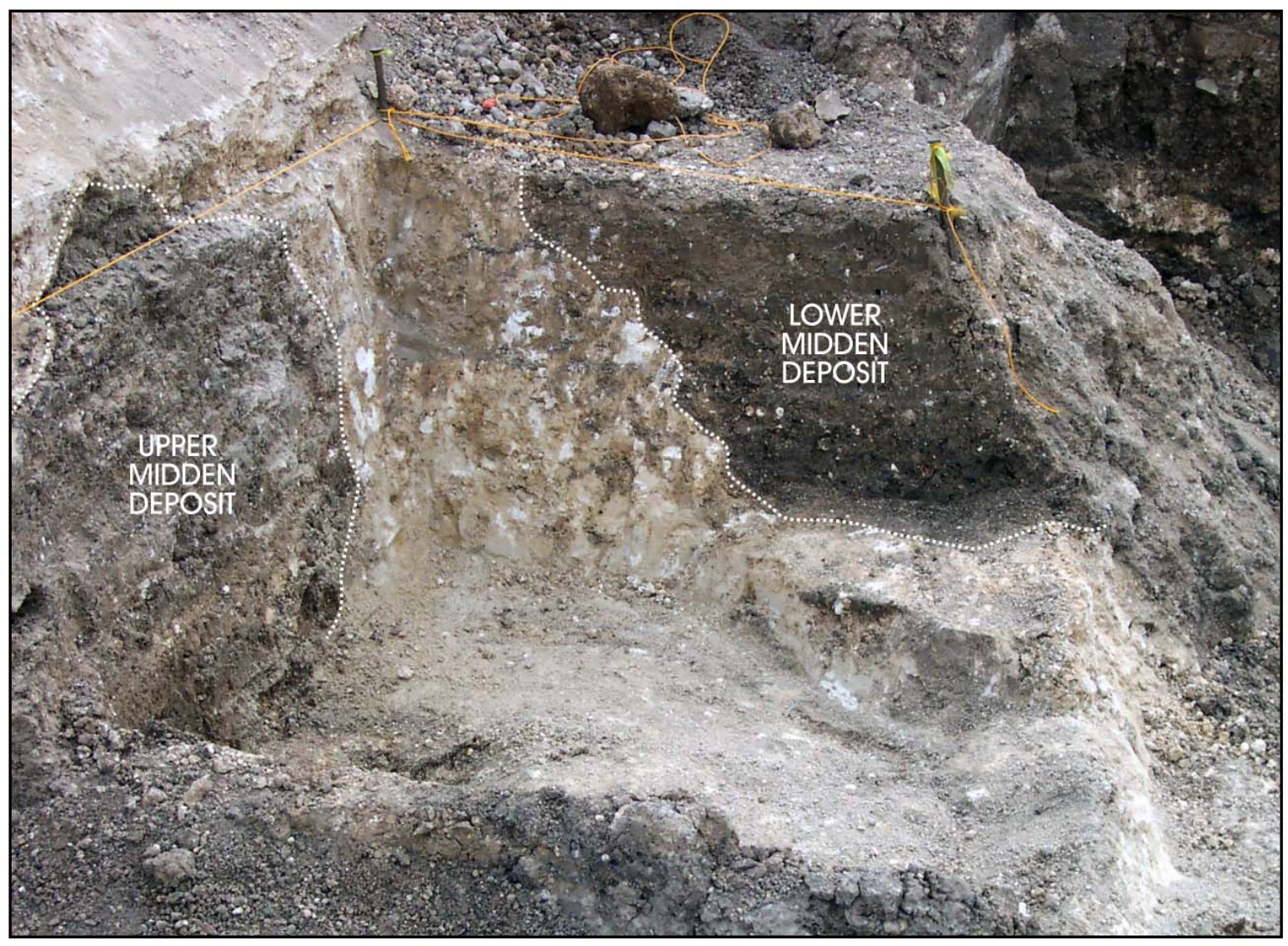

Figure 8-13. Unit 7 after excavation. Note lower midden clearly visible in south wall, and upper midden visible in east wall.

Table 8-7. Artifact Densities by Types for Southern Midden (upper and lower) and Northern Midden

\begin{tabular}{|l|c|c|c|}
\hline \multicolumn{1}{|c|}{ Artifact Type } & $\begin{array}{c}\text { Upper } \\
\text { Midden } \\
\text { Deposit }\end{array}$ & $\begin{array}{c}\text { Lower } \\
\text { Midden } \\
\text { Deposit }\end{array}$ & $\begin{array}{c}\text { Northern } \\
\text { Midden } \\
\text { Deposit }\end{array}$ \\
\hline Native American Wares & 15.1 & 22.9 & 41 \\
\hline Spanish Colonial Wares & 317.0 & 165.7 & 259.5 \\
\hline English Wares & 45.3 & 0 & 54.3 \\
\hline Glass & 37.7 & 17.1 & 19.8 \\
\hline Metal & 45.3 & 5.7 & 42.3 \\
\hline Button & 7.5 & 0 & 2 \\
\hline Debitage & 158.5 & 57.1 & 67.5 \\
\hline Lithic Tools & 15.1 & 5.7 & 3 \\
\hline Gunflints & 0.0 & 5.7 & 1.5 \\
\hline Burned Rock & 158.5 & 228.6 & 91.75 \\
\hline Bone (count) & 7554.7 & 1091.4 & 3001.8 \\
\hline Total & 8354.7 & 1599.9 & 3584.5 \\
\hline
\end{tabular}


does the density of material in the lower midden deposit exceed the upper midden deposit. An examination of Table 8-7 will clearly show that both the content and amount of material deposited changed dramatically between the upper and lower zones of this southern midden.

The differences between the upper and lower midden deposits, as well the overall intensity of use through time of this midden, can be seen in Figure 8-14. The figure plots the volumetrically corrected total number of artifacts for each level of the deposit through Level 15, the bottom of this midden. Depositional rates were relatively stable in the lower midden deposit, with almost no deposition in Level 7. After Level 7, rates increased dramatically, with Level 2 having roughly an eight-fold increase in depositional intensity when compared to the average rates for levels in the lower midden deposit. Figure 8-15 focuses on volumetrically corrected bone weight for these same 15 levels. Here, the overall pattern is roughly the same as seen in Figure 8-14, with dramatic differences in bone weight between the upper and lower deposits. While peaks in bone weight are different than those produced by the total number of items, there was a general increase in intensity of use from the beginning of the formation of the upper deposit, a pattern reflected in Figure 8-14.

While no flotation samples were collected from this midden, a variety of species were identified in the faunal material (see Table 7-1; Appendix A). These included bison in the upper portion of the southern midden, along with cattle, turkey, pig, chicken, and sheep/goat. The lower midden deposits had a smaller number of items, most of which could only be classified as unidentified mammal remains. However, chicken, pig, and deer were also identified in the lower deposits.

While the low number of ceramic sherds from the southern midden precludes any statistical analysis, Figure 8-16

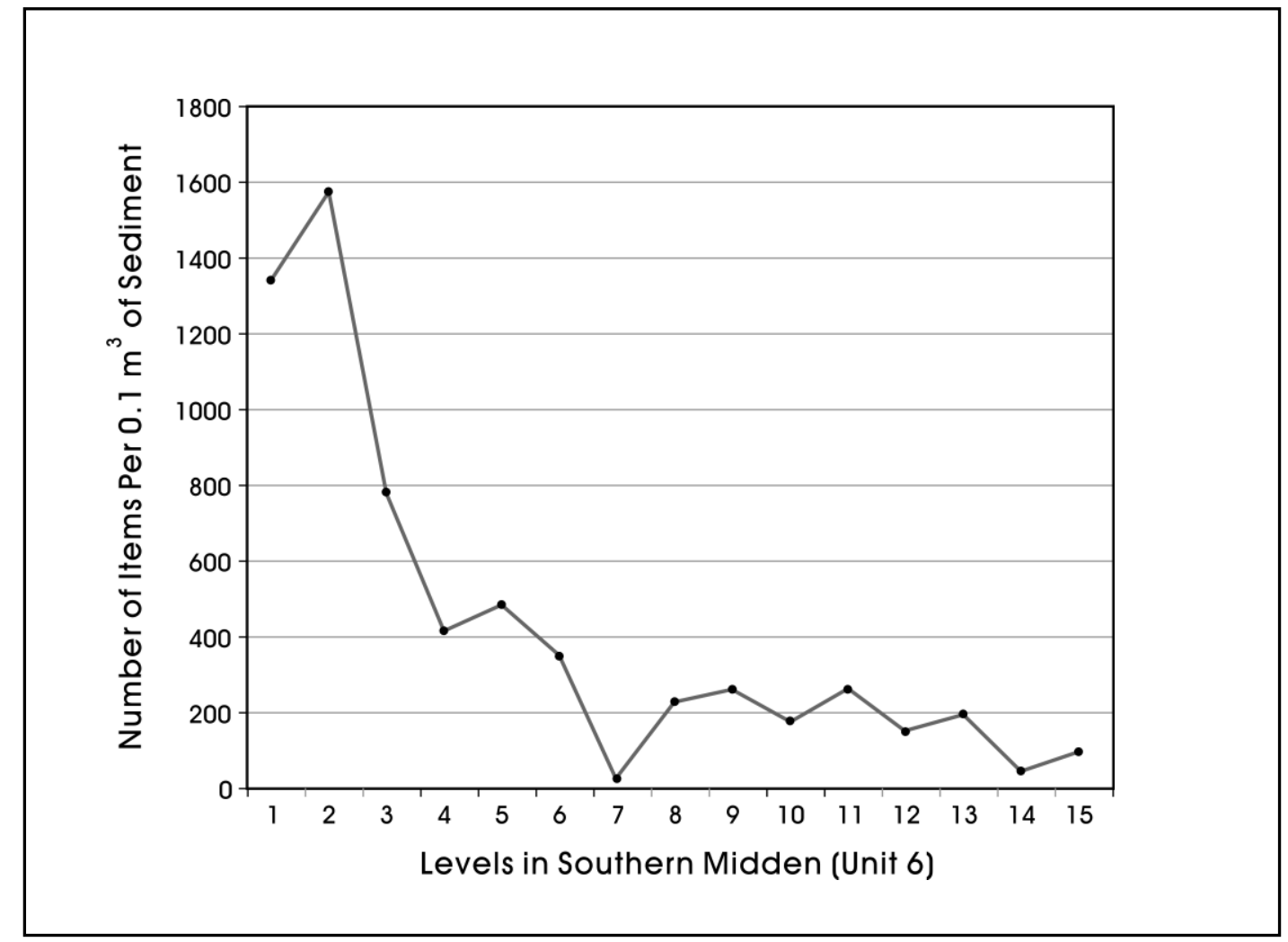

Figure 8-14. Line graph of number of items per $0.1 \mathrm{~m}^{3}$ of sediment for levels in southern midden (Midden 2). 


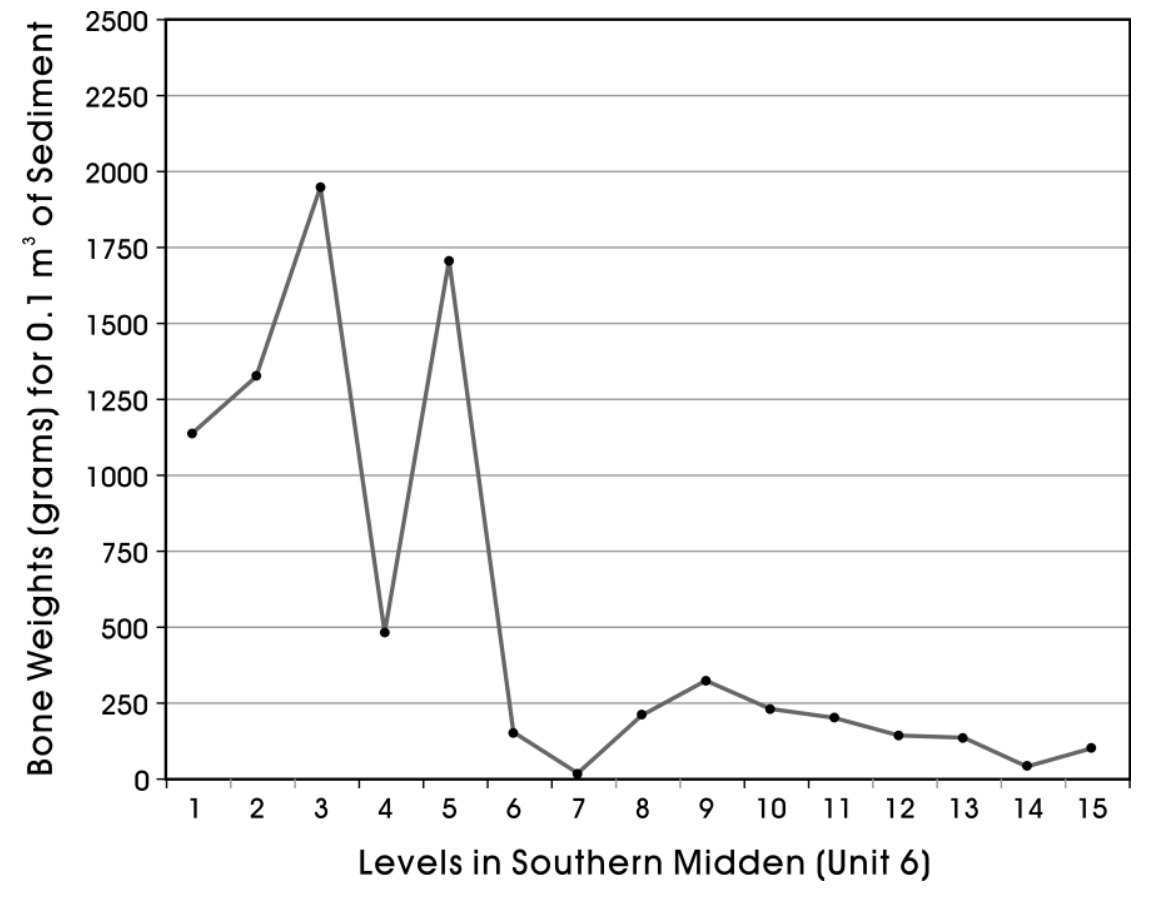

Figure 8-15. Line graph of bone weight per $0.1 \mathrm{~m}^{3}$ of sediment for levels in southern midden (Midden 2).

presents the ceramic types that could be assigned to a temporal span for the upper (top of figure) and lower (bottom of figure) midden deposits. The upper midden is dominated by Galera and sandy paste wares, which suggest that the primary period of deposition may have been between about 1700 and 1850. The presence of English wares, including annular/banded slip, suggests a termination date of sometime after 1850 for this upper deposit. Note that this midden was capped by construction associated with the St. Joseph's Orphan Asylum, and it was probably abandoned before the construction of the Charity Hospital in the late 1860s. The upper deposit in the southern midden, then, appears, based on ceramic types, to have been roughly contemporary with the northern midden formation, though the latter had a wider variety of English wares. Reference to the bottom portion of Figure 8-16 will show that in the lower deposits of the southern midden, the primary ceramic types were Galera, Goliad, and sandy paste wares. While the overall sample size is small from this section of the midden, these three types suggest a principal period of use sometime between 1650 and 1850 . In fact, no ceramics from these lower levels date after 1850, suggesting that this lower midden deposit may be representative of early Colonialperiod deposition. Given that these deposits were capped by the upper midden, a terminal date of use of sometime before 1800 may be a realistic estimate.

\section{Summary}

The southern midden at 41BX1598 consisted of two distinct deposits. Size and shape characteristics, as well as volume estimates, could not be made for the upper deposit, as portions were removed by BHT 5, and some portion of the midden was certainly destroyed by subsequent construction at the site in the 1860s. The lower zone in the southern midden was a circular, basin-shaped deposit, with an estimated volume of about $1.4 \mathrm{~m}^{3}$, significantly smaller than Midden 1 located to the north. Using data from Unit 6, which cut through both the upper and lower deposits, these two 


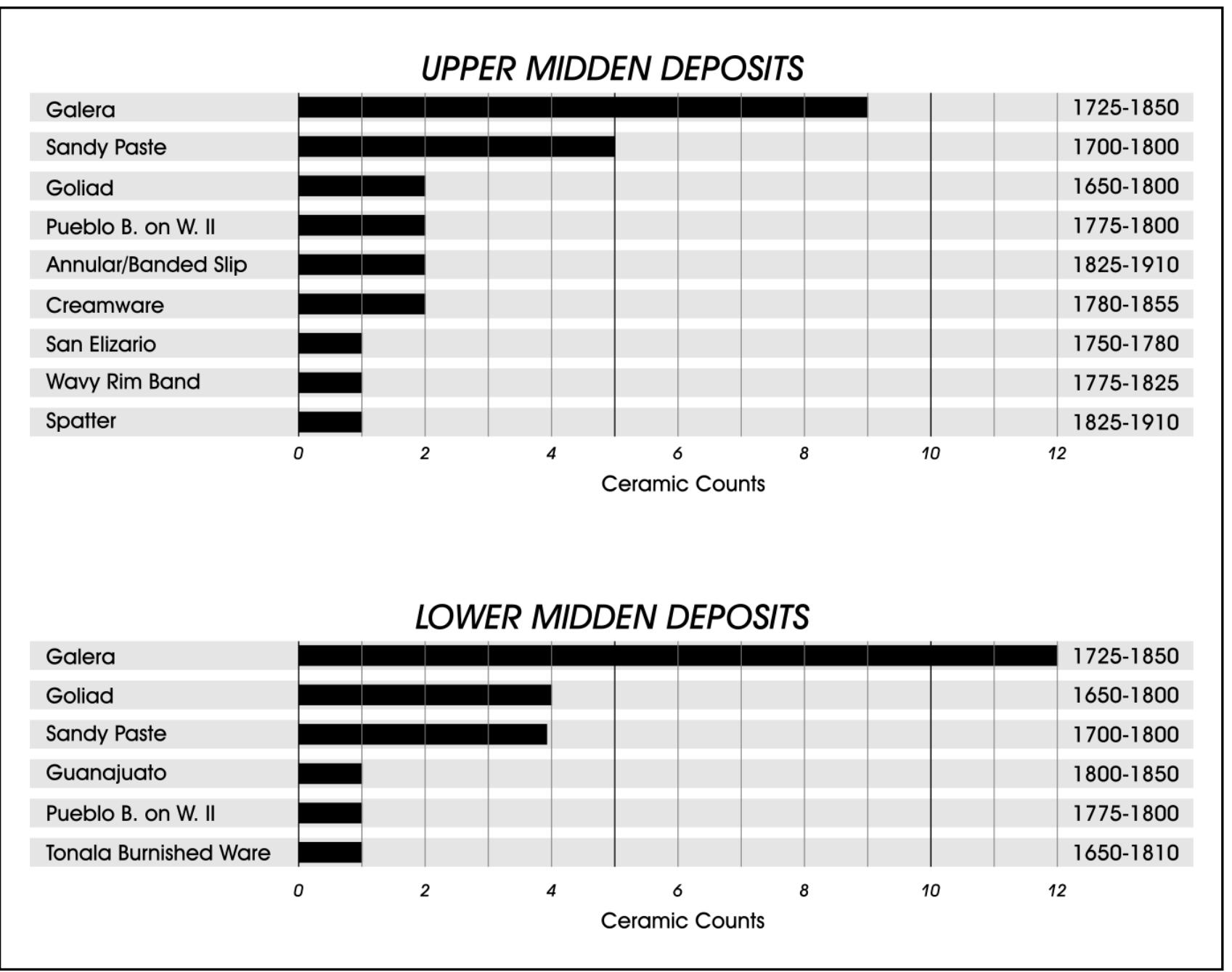

Figure 8-16. Ceramic types recovered in the upper and lower deposits within the southern midden (Midden 2).

deposits seem to reflect the deposition of what was primarily domestic trash. The lower portion of the midden contained distinct lenses of material, which may represent specific depositional episodes. Ceramics, coupled with the dates of construction of the Charity Hospital, suggest that the upper portion of the midden probably formed sometime between 1800 and the late 1860s. The lower portion of the midden could have begun forming prior to 1700 , and while a termination date for this deposit is difficult to estimate, sometime around 1800 seems reasonable, especially as this portion of the deposit was capped by the upper midden zone. Using either artifact numbers or bone density, it appears that the intensity of midden use increased substantially after the abandonment of the lower portion of the midden, an abandonment that was clearly visible as a distinct level of yellow sandy sediment separating the upper from the lower deposits. The faunal material recovered from the midden was dominated by unidentified mammal remains. Of those items that could be identified, both domesticated and wild species were present, with domesticates including chicken, goat/sheep, cattle, and pig. Bison was also recovered from the upper portion of this southern midden. 


\section{Midden Comparisons}

The presence of the northern midden deposit as well as the upper and lower zones within the southern midden, all of which seem to date to the Colonial period, provide the opportunity for comparison. In addition, note that while hampered by both extremely small samples sizes from the southern feature, and by the possibility that, for at least some ceramic types (i.e., Goliad) our estimated age ranges may require refinement, the ceramic age ranges for the middens suggest that the lower deposits within the southern midden formed earlier than the northern midden, and it was certainly earlier than the upper deposit in that same midden. The lower deposits within the southern midden may date to before 1700 , with a terminal date of around 1800 . The upper deposits within the southern midden date to after 1800 , and refuse was no longer deposited at this location after the late 1860 s. Finally, the northern midden seems to be roughly contemporary with the upper deposits of the southern midden, especially in light of potential problems associated with the termination date for Goliad ware. These various deposits, then, could easily span much of the Colonial period, and may provide the opportunity to investigate changes within this time frame.

In order to explore the possibility that these three midden deposits provide the opportunity to investigate temporal changes within the Colonial period, we investigate two measures that may provide at least relative temporal rankings of these deposits. The first of these is the percentage of English whitewares within the ceramics recovered from the middens. English wares were increasingly brought into the region after the early 1800 s, were common after 1850 , and seem to dominate ceramic assemblages, especially those from the later part of the nineteenth century. Consequently, deposits that date late in time should have an increased percentage of English wares within the ceramic assemblage. The second measure that may provide relative temporal placement is the percentage of metal and glass artifacts within a group that contains metal, glass, debitage, lithic tools, gunflints, and burned rock. Metal and glass artifacts increasingly replaced lithics later in time. Assemblages dominated by high percentages of metal and glass, then, should date later than assemblages dominated by debitage, lithic tools, gunflints, and burned rock.

Figure 8-17 presents these two measures for the three distinct deposits at 41BX1598. Reference to the figure will suggest that with regard to the percentage of English ceramics within the ceramic assemblages from these two middens, the lower deposit of the southern midden clearly has the lowest overall percentage, while the upper southern midden deposit has a slightly lower percentage than the northern midden. To the degree, then, that this measure can be used as a relative temporal indicator, the lower deposit in the southern midden is clearly earliest, with the northern deposit being slightly later in time than the upper portion of the southern midden. Turning to the second variable, the percentage of metal and glass within a group of artifacts that includes glass, metal, and lithics, we see that essentially the same pattern is repeated. Metal and glass artifacts make up roughly $7 \%$ of the artifacts within this group in the lower deposit of the southern midden, and rise to over $27 \%$ in the northern midden. Once again, the upper portion of the southern midden is intermediate, with about $20 \%$. These rankings are consistent with those suggested by the ceramic temporal assignments noted previously for these deposits. They lend further support to the suggestion that the lower deposit in the southern midden is the earliest encountered at 41BX1598. They further suggest that though there is probably significant temporal overlap between the upper deposit within the southern midden and the northern midden, the northern midden, as a whole, may be later in time.

These relative age rankings of the deposits allow us to investigate changes within the Colonial period. Specifically, we focus on changes in subsistence using the faunal material. As noted in this chapter, as well as the previous one, faunal material represents both the major category of material recovered at the site, as well as the major component of each of the three midden deposits. Unfortunately, identification of these remains beyond the class taxonomic level was not possible in the vast majority of cases, as much of the material is highly fragmented (see Appendix A). Sample sizes for this inquiry are further reduced by our $\mathrm{f}$ ocus on faunal remains that have a high probability of reflecting food items.

Given these sample size limits, we group the faunal material into three broad classes based on body size in order to investigate subsistence changes within the Colonial-period deposits. Though usually used in the context of hunter-gather research, a number of studies associated with foraging theory (see Kelly 1995; Simms 1987; Stephens and Krebs 1986) have demonstrated that animal body size is related to caloric return such that larger-sized animals have higher overall energy return rates when considered in the context of caloric return relative to processing costs. While the application of any such position in the current context is complicated by the increasing existence of a market economy, especially 


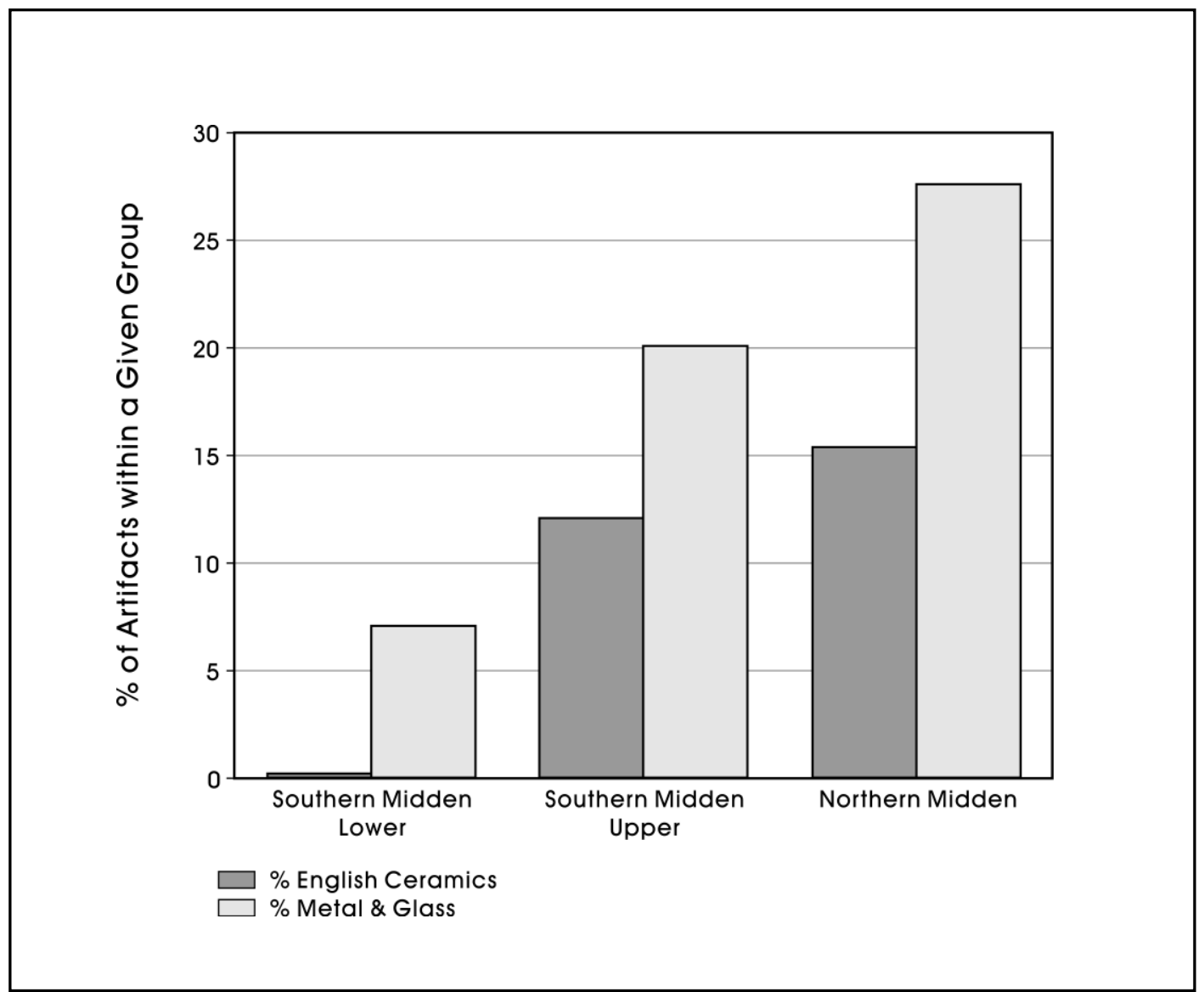

Figure 8-17. Graph showing percentage of artifacts within a given group for the three different midden deposits at $41 B X 1598$.

after the $1870 \mathrm{~s}$ in the region, and the presence of domesticated animals, access to which may be variable given different socioeconomic concerns, the body size grouping provides a convenient method for investigation of subsistence change within these deposits.

The first size group, designated as small-sized animals, includes all birds (both domestic and wild), all fish, and turtles and tortoises. Note that the single rodent element was eliminated from consideration as it has a low probability of being a food item. Medium-sized animals include all deer, antelope, sheep and goat, pig, and peccary, as well as all material identified as only belonging to the order Artiodactyla. While this order includes several animals that would be classified as large or very large mammals, the unidentified artiodactyl remains from the middens at 41BX1598 are all within the size ranges of sheep, goat, deer, antelope and pig. Note that remains of Canis were not included in this category. Finally, the large and very large size class included all bison, cattle, and all specimens identified only as Bovinae. Horse was eliminated from consideration.

Figure 8-18 presents the percentage of the faunal material by size class occurring in each of the three midden contexts. While the sample sizes, especially in the lower portion of the southern midden, are minimal, the patterns in Figure 8-18 clearly suggest changes in diet through time within these three midden contexts. The lower midden deposit in the southern midden is dominated by small-sized animals (ca. $60 \%$ ), with large mammals comprising only $4 \%$ of the admittedly small sample. Small animals in the upper portion of the southern midden comprise just over $20 \%$ of the identified faunal material, with large and very large 


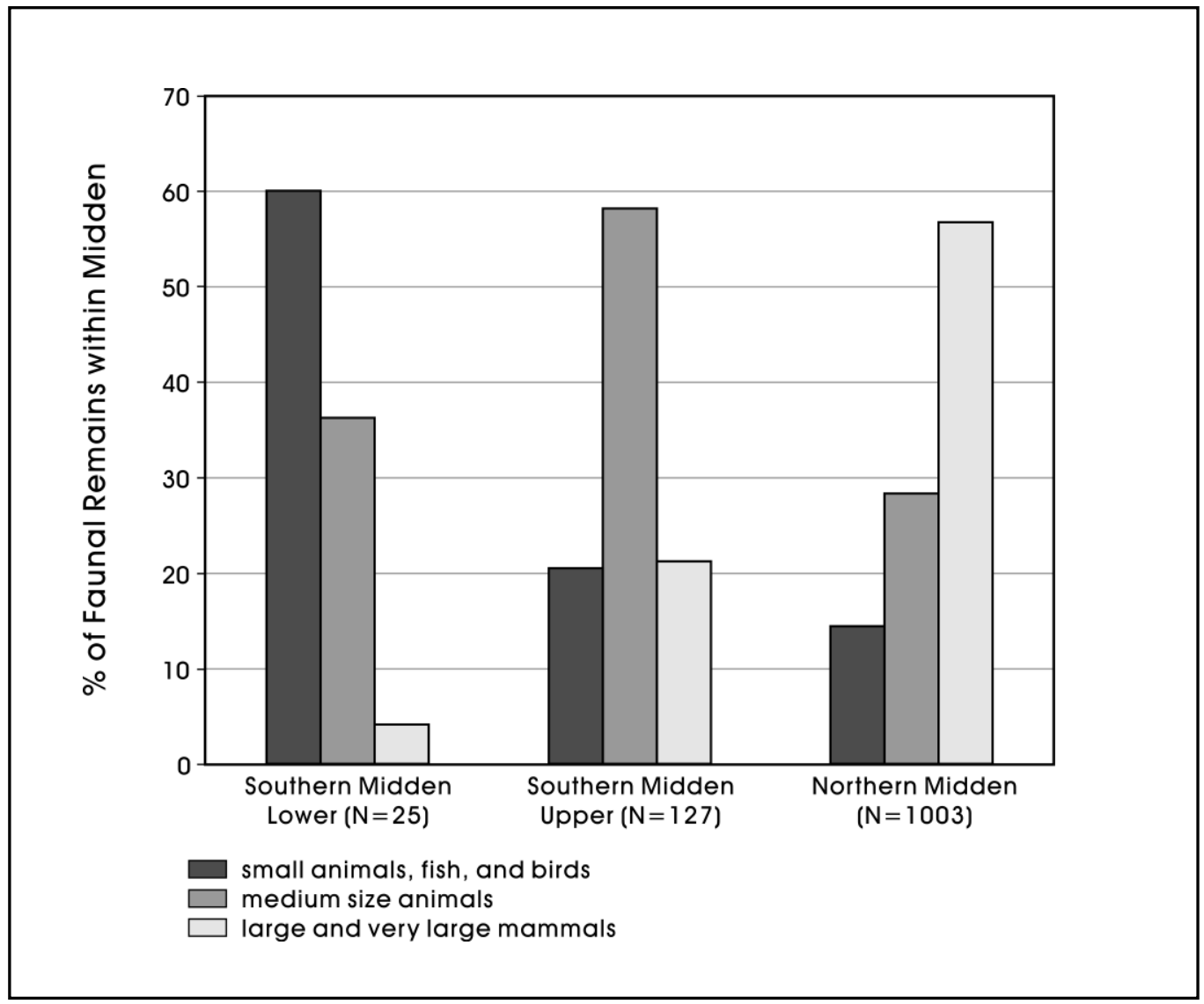

Figure 8-18. Graph showing percentage of faunal remains by body size groupings for the midden deposits at $41 B X 1598$.

mammals comprising roughly the same percentage. In the latest deposits, represented by the northern midden, large and very large mammals dominate $(57 \%)$, and the contribution of small-sized animals falls to under $15 \%$. These changes suggest that during the formation of the lower portion of the southern midden, perhaps prior to 1700 , the availability of large and very large animals to the populations using that midden was relatively low. Large and very large animals should be acquired whenever they are available, given their higher return rates.

Interestingly, much of the increase in the large and very large mammal group shown in the figure seem to be related to the percentage of Bos taurus (cattle). Faunal remains identified as cattle are not present in the lower component of the southern midden. They make up $3.7 \%$ of the large and very large mammal group in the upper portions of that midden. Finally, faunal material identified as Bos taurus comprises
$17.4 \%$ of the large and very large group in the northern midden. It appears, then, that occupants using the northern midden had increased access to large and very large mammals in general, and cattle in particular, relative to the earlier periods. It is probable that this increased access to large and very large animals caused a shift in the overall diet, with medium, and especially small-sized animals, being dropped from the diet.

\section{Summary}

CAR's work at 41BX1598 uncovered a variety of features, walls, and other architectural details. Most of the wall segments uncovered were associated with structures documented in our archival research. One interesting exception was a wall segment located in the southwestern portion of the property, the lower portion of which had characteristics consistent with Colonial-age construction. 
While it is possible that this wall segment is associated with the Presidio San Antonio de Béxar, no Colonial-age artifacts were associated with this wall, and a small piece of asphalt was recovered from within the wall during removal. Varieties of pit features were recorded during monitoring of backhoe trenching at the site. Most of these appear to be post-Colonial in age. However, two midden features that date primarily to the Colonial period were documented and explored. A large, stratified northern midden deposit produced a variety of Colonial-age artifacts, including large quantities of faunal material. A second Colonial-age midden was uncovered in the southern portion of the site. This second midden contained two distinct deposits separated by an essentially sterile layer. Ceramics recovered from the lower midden deposit suggest that it may have begun forming prior to 1700 . An analysis of various aspects of these three midden deposits produced evidence that subsistence changed during the Colonial period, with an increasing emphasis on large and very large mammals, primarily cattle, later in time. In addition, the stratified characteristics of the northern midden provided the opportunity to explore the date ranges for several of the ceramic types present. The vertical distribution of the ceramics suggests that either Native American Goliad wares continued to be manufactured into the 1800 s or English annular/banded slip and whitewares made it into the region sometime before 1825 (see also Fox 1992:46). 



\section{Chapter 9: Summary and Conclusions}

In late 2003, the Center for Archaeological Research (CAR) of The University of Texas at San Antonio performed archaeological testing and monitoring at site 41BX1598, the location of the proposed San Fernando Community Center, located adjacent to Military Plaza in downtown San Antonio, Bexar County, Texas. The work performed by CAR was done under contract with the San Antonio Archdiocese, and in conjunction with Sprinkle Robey Architects and SpawGlass contractors. Agency oversight was provided by the City of San Antonio Historic Preservation Office, and the work was conducted in accordance with and under the jurisdiction of the City Preservation Ordinance (Article VI, Historic Preservation and Urban Design, City of San Antonio, Unified Development Code).

The initial phase of construction work consisted of the excavation of a roughly 0.12 -acre (ca. $500 \mathrm{~m}^{2}$ ) hole, 21 feet $(6.4 \mathrm{~m})$ deep, for the construction of a City Public Service vault associated with the development of the Community Center. That excavation cut through what appeared to be Colonial-age deposits. As a result of this discovery, CAR was contacted by representatives of the Archdiocese of San Antonio, and in consultation with the City of San Antonio Historic Preservation Office, initiated a series of activities designed to determine the nature and extent of Colonial deposits, and sample those deposits. In addition, CAR personnel monitored ongoing construction activities to insure that other such deposits, if encountered, would be sampled. Finally, archival research on the property was undertaken to document any historically important uses of the location.

In the field, CAR used a variety of methods, including the excavation of nine shovel tests, mechanical stripping of deposits, the hand excavation of five 1-x-1-m units and two $50-x-50-\mathrm{cm}$ units, and the excavation of six backhoe trenches, to investigate the property. Archival research involved reference to Sanborn Insurance Maps, as well as a variety of historic maps and documents.

Our results suggest that the occupation of the San Fernando Community Center property, site 41BX1598, spanned well over 200 years, perhaps dating back to before 1700 . Two midden deposits, a variety of architectural remains, and several pit features were uncovered, along with over 1,500 artifacts and over 13,000 pieces of animal bone. The midden deposits on the site represent the earliest periods of use, with both the southern and northern middens containing Colonial-age deposits. The lower portion of the southern midden, in fact, may have begun forming prior to 1700 . In addition, there is some evidence, though the case is not clear cut, that a section of a Colonial-period wall was documented. Archival research, as well as archaeological work at the site, documented that the property had a variety of uses stretching back into the 1700 s, when it was used as a personal residence. More recent uses include the construction of the Santa Rosa Charity Hospital in the late 1860s, and the construction of the St. Joseph's Orphan Asylum shortly thereafter. The orphanage was in use until the early 1900 s.

Perhaps the most interesting aspect of the project was the opportunity to document and investigate the midden deposits at the San Fernando Community Center property. These features offer archaeological evidence of a period of time in San Antonio that is still not well understood. While, as summarized previously, our work provided a wide variety of artifacts from this period, two aspects of our analysis should be highlighted. The first involves the possibility that at least some aspects of our current understanding of date ranges for certain ceramic types may need refinement (i.e., Native American Goliad ware, English annular/banded slip and whitewares). Further work on this issue will require well-stratified deposits with large sample sizes. The second highlight of the research is the suggestion that during the Colonial period, significant changes in subsistence occurred at this location. As seen in the faunal assemblage, a significant reduction in diet breadth may have occurred throughout this period, as later deposits were contained primarily large-sized animals. A very different situation is suggested by the earlier deposits, where a large percentage of the diet appears to have been comprised of smaller body sized animals. These changes, if confirmed by subsequent work on sites of this period, would have certainly impacted other components of Colonial-period adaptation, including shifts in aspects of technology. 



\section{References Cited}

Barnes, M. R., and R. V. May

1972 Mexican Majolica in Northern New Spain. Pacific Coast Archaeological Society Occasional Paper, No. 2.

Barr,A.

2004 Bexar, Siege of. The Handbook of Texas Online, http://www.tsha.utexas.edu/handbook/online/ articles/view/BB qeb1.html, accessed October 14.

Bauer, J.

1974 The Mexican War, 1846-1848. Macmillan, New York.

Buckley, E. C.

1911 The Aguayo Expedition into Texas and Louisiana, 1719-1722. Quarterly of the Texas State Historical Association $\mathrm{XV}(1): 1-65$.

Buerkle, R. C.

1976 The Continuing Military Presence. In San Antonio in the 18th Century. San Antonio Bicentennial Heritage Committee.

Campbell, T. N., and T. J. Campbell

1981 Historic Indian Groups of the Choke Canyon Reservoir and Surrounding Areas. Choke Canyon Series, Volume 1. Center for Archeological Research, The University of Texas at San Antonio.

Chipman, D. E.

1992 Spanish Texas, 1519-1821. University of Texas Press, Austin.

Cox, I. W.

1986 Excavations of Portions of the San Pedro Acequia (41BX337) and a Search for the Arocha Acequia, San Antonio, Texas. Archaeological Survey Report, No. 161. Center for Archaeological Research, The University of Texas at San Antonio.

1995 Documentation of the San Pedro Acequia (41BX337) at Trevino Street, San Antonio, Texas. Archaeological Survey Report, No. 230. Center for Archaeological Research, The University of Texas at San Antonio.

Davidson, B., and J. W. Clark

1978 Faunal Analysis. In Mission San José y San Miguel de Aguayo: Archaeological Investigations, December 1974, edited by J. W. Clark, pp. 135-193. Office of the Sate Archeologist, Austin.

Dering, $P$.

2002 Appendix E: Botanical Remains Analysis. In Archeological Investigations at the Last Spanish Colonial Mission Established on the Texas Frontier: Nuestra Señora del Refugio (41RF1), Refugio County, Texas, Volume 1CD, by C. L. Tennis. Archaeological Survey Report, No. 315, Center for Archaeological Research, The University of Texas at San Antonio. Archeological Studies Program Report 39, Texas Department of Transportation Environmental Affairs Division.

2003 Plant Remains from the Vargas Site (41ED28). Manuscript submitted to TRC Environmental, Austin, Texas. 
Eaton, J. D.

1980 Excavations at the Alamo Shrine (Mission San Antonio de Valero). Archaeological Survey Report, No. 10. Center for Archaeological Research, The University of Texas at San Antonio.

Everitt, B. S.

1977 The Analysis of Contingency Tables. London: Chapman and Hall.

Felger, R. S.

1977 Mesquite in Indian Cultures of Southwestern North America. In Mesquite: Its Biology in Two Desert Ecosystems, edited by B. B. Simpson. Pp. 150-176. Stroudsburg, Pennsylvania: Dowden, Hutchinson, and Ross, Inc.

Fox, A. A.

1977 The Archaeology and the History of the Spanish Governor's Palace Park. Archaeological Survey Report, No. 31. Center for Archaeological Research, The University of Texas at San Antonio.

1992 Archaeological Investigations in Alamo Plaza, San Antonio, Bexar County, Texas (1988 and 1989). Archaeological Survey Report, No. 205. Center for Archaeological Research, The University of Texas at San Antonio.

1997 Test Excavations at the Spanish Governor's Palace, San Antonio, Texas. Archaeological Survey Report, No. 259. The Center for Archaeological Research. The University of Texas at San Antonio.

n.d. Identification of Ceramics from Colonial Sites in Texas. Draft manuscript on file, Center for Archaeological Research, The University of Texas at San Antonio.

Fox, A. A., F. A. Bass, Jr., and T. R. Hester

1976 The Archaeology and History of Alamo Plaza. Archaeological Survey Report, No. 16. Center for Archaeological Research, The University of Texas at San Antonio.

Fox, A. A., and I. W. Cox

2000 Archaeological Monitoring for Exterior Lighting and Test Excavations at Mission San Juan Capistrano, Bexar County, Texas. Letter Report, No. 131. Center for Archaeological Research, The University of Texas at San Antonio.

Fox, A. A., I. W. Cox, L. Highley, and D. Hafernik

1989 Archaeological and Historical Investigations at the Site of the New Bexar County Justice Center in Downtown San Antonio, Texas. Archaeological Survey Report, No. 184. Center for Archaeological Research, The University of Texas at San Antonio.

Fox, A. A., and M. Renner

1999 Historical and Archaeological Investigations at the Site of Rivercenter Mall (Las Tiendas), San Antonio, Texas. Archaeological Survey Report, No. 270. Center for Archaeological Research, The University of Texas at San Antonio.

Fox, A. A., M. Renner, and R. J. Hard

1997 Archaeology at the Alamodome: Investigations of a San Antonio Neighborhood in Transition, Volume III: Artifacts and Special Studies. Archaeological Survey Report, No. 238. Center for Archaeological Research, The University of Texas at San Antonio. 
Fox, D. E., D. Scurlock, and J. W. Clark

1977 Archaeological Excavations at San Fernando Cathedral, San Antonio, Texas: A Preliminary Report. Office of the State Archeologist, Texas Historical Commission, Austin.

Gerald, R.E.

1968 Spanish Presidios of the Late Eighteenth Century in Northern New Spain. Museum of New Mexico Research Records 7, Museum of New Mexico Press.

Greer, G.H.

1999 American Stonewares: The Art and Craft of Utilitarian Potters. Atglen: Schiffer Publishing, Ltd.

Greer, J. W.

1967 A Description of the Stratigraphy, Features, and Artifacts from an Archeological Excavation at the Alamo. Archeological Program, Report 3. State Building Commission, Austin.

Haberman, S. J.

1973 The Analysis of Residuals in Cross-classified Tables. Biometrics 29:205-220.

Habig, M.A.

1977 The Alamo Mission, San Antonio de Valero 1718-1793. Chicago: Franciscan Herald Press.

Hall, G.

2000 Pecan Food Potential in Prehistoric North America. Economic Botany 54:103-112.

Hall, G. D., T. R. Hester, and S. L. Black (editors)

1986 The Prehistoric Sites at Choke Canyon Reservoir, Southern Texas: Results of the Phase II Archaeological Investigations. Choke Canyon Series, No. 10. Center for Archaeological Research, The University of Texas at San Antonio.

Hard, R. J., A. A. Fox, I. W. Cox, K. J. Gross, B. A. Meissner, G. I. Méndez, C. L. Tennis, and J. E. Zapata,

1995 Excavations at Mission San José y San Miguel de Aguayo, San Antonio, Texas. Archaeological Survey Report, No. 218. Center for Archaeological Research, The University of Texas at San Antonio.

Hester, T. R.

1995 The Prehistory of South Texas. Bulletin of the Texas Archeological Society 66:427-459.

Hoffman, F. L. (translator)

1937 Diary of the Alarcón Expedition into Texas, 1718-1719. Quivira Society Publications Volume 5: 39.

Inman, B. J., T. C. Hill, Jr., and T. R. Hester

1998 Archeological Investigations at the Tortugas Flat Site, 41ZV155, Southern Texas. Bulletin of the Texas Archeological Society 69:11-33.

Kelly, R. L.

1995 The Foraging Spectrum. Smithsonian Institution Press, Washington, D.C.

Labadie, J. H.

1986 Additional Archaeological and Historical Studies for the Fairmount Hotel Project in San Antonio, Texas. Archaeological Survey Report, No. 160. Center for Archaeological Research, The University of Texas at San Antonio. 
McKenzie, C. M. M.

1995 The 1995 Plaza de Armas Archeological Monitoring Project San Antonio, Bexar County, Texas. Report Submitted to the Department of Antiquities Protection, Texas Historical Commission. St. Mary's University, San Antonio.

Mauldin, R. P., B. K. Moses, R. D. Greaves, S. A. Tomka, J. P. Dering, and J. D. Weston

2004 Archeological Survey and Testing of Selected Prehistoric Sites along FM 481, Zavala County, Texas. Archaeological Survey Report, No. 352, Center for Archaeological Research, The University of Texas at San Antonio, and Archeological Studies Program, Report No. 67, Environmental Affairs Division, Texas Department of Transportation, Austin.

Meissner, B. A.

1996 Faunal Analysis. In Excavation of the San Pedro Acequia on the Grounds of the San Antonio Housing Authority, by D. L. Nickels, I. W. Cox, and C. Gibson, pp. 40-41. Archaeological Survey Report, No. 243. Center for Archaeological Research, The University of Texas at San Antonio.

1997 Appendix A: Analysis of Vertebrate Faunal Remains. In The Archaeology and the History of the Spanish Governor's Palace Park, by A. A. Fox, pp. 18-28. Archaeological Survey Report, No. 31. Center for Archaeological Research, The University of Texas at San Antonio.

Menchaca, A.

1937 Memoirs. Yanaguana Society, San Antonio.

Moorhead, M.

1991 The Presidio: Bastion of the Spanish Borderlands. University of Oklahoma Press; Norman.

Nance, J. M.

2004 Republic of Texas. The Handbook of Texas Online, http://www.tsha.utexas.edu/handbook/online/articles/view $\mathrm{RR} / \mathrm{mzr} 2 . \mathrm{html}$, accessed October 14.

Nickels, D. L.

20001999 Excavations at Mission Rosario. Archaeological Survey Report, No. 298. Center for Archaeological Research, The University of Texas at San Antonio.

Nickels, D. L., I. W. Cox, and C. Gibson

1996 Excavation of the San Pedro Acequia on the Grounds of the San Antonio Housing Authority. Archaeological Survey Report, No. 243. Center for Archaeological Research, The University of Texas at San Antonio.

Orozco, C.E.

2004 Garza, José Antonio De La. The Handbook of Texas Online, http://www.tsha.utexas.edu/ handbook/online/, accessed October 14.

Rea, F.

1997 By the Desert's Green Edge. Tucson: University of Arizona Press.

Russell, F.

1908 The Pima Indians. In Twenty-sixth Annual Report of the Bureau of American Ethnology, [1904-1905], pp. 17-389. Washington, D.C. 
Sanborn Fire Insurance Maps

1877 Digital Sanborn Maps 1867-1970, http://www.cah.utexas.edu/sanbornmaps/sanborn_st.html, accessed October 2005.

1885 Digital Sanborn Maps 1867-1970, San Antonio July 1885, Sheet 8, http://sanborn.umi.com/, accessed October 2005.

1911 Digital Sanborn Maps 1867-1970, San Antonio 1911-1924, Volume 1, 1911, Sheet 4, http://sanborn.umi.com/, accessed October 2005.

1951 Digital Sanborn Maps 1867-1970, San Antonio 1911-March 1951 Volume 1, 1911- December 1950, Sheet 4, http://sanborn.umi.com/, accessed October 2005.

Schuetz, M. K.

1966 Historic Background of the Mission San Antonio de Valero. Report 1. State Building Commission Archeological Program, Austin.

1969 The History and Archeology of Mission San Juan Capistrano, San Antonio, Texas, Volume 2: Description of the Artifacts and Ethnohistory of the Coahuiltecan Indians. Archeology Program Report 11. State Building Commission, Austin.

1973 Archeological Investigations at Mission San Antonio de Valero, the Second Patio. Manuscript on file, Office of the State Archeologist, Texas Historical Commission, Austin.

Simms, S.

1987 Behavioral Ecology and Hunter-Gatherer Foraging: An Example from the Great Basin. British Archaeological Reports, International Series 381. Oxford.

Slattery, Sister Margaret Patrice C.C.V.I.

1995 Promises to Keep: A History of the Sisters of Charity of the Incarnate Word, San Antonio, Texas. Vol. 1-2. Manuscript on file, Center for Archaeological Research, The University of Texas at San Antonio.

Sorrow, W. M.

1972 Archeological Salvage Excavations at the Alamo (Mission San Antonio de Valero) 1970. Report No. 4. Texas Archeological Salvage Project Research, Austin.

Steinfeldt, C.

1979 San Antonio Was: Seen Through a Magic Lantern. San Antonio Museum Association.

Stephens, D. W., and J. R. Krebs

1986 Foraging Theory. Princeton, New Jersey: Princeton University Press.

Taylor, C.

1994 Juniper Symposium. Technical Report 94-2, Texas A\&M University Research Station at Sonora.

Tennis, C. L., and I. W. Cox

1998 Archaeological Monitoring for San Antonio Water Systems: Henry B. Gonzalez Convention Center Expansion. Archaeological Survey Report, No. 281. Center for Archaeological Research, The University of Texas at San Antonio. 
Tomka, S., and A. A. Fox

1998 Mission San Jose Indian Quarters Wall Base Project, Bexar County, Texas. Archaeological Survey Report, No. 278. Center for Archaeological Research, The University of Texas at San Antonio.

Tunnell, C. D.

1966 A Description of Enameled Earthenware from an Archeological Excavation at Mission San Antonio de Valero (the Alamo). Archeological Program Report 2. State Building Commission, Austin.

Uecker, H. G., F. K. Meskill, and I. W. Cox

1991 Archaeological Investigations at the Ruiz Family Property (41BX795), San Antonio, Texas. Archaeological Survey Report, No. 198. Center for Archaeological Research, The University of Texas at San Antonio.

Villalobos, C.

2003 A Study of Gunflints from Spanish Colonial Sites. Unpublished Master's thesis, University of Texas at San Antonio. On file, Center for Archaeological Research, The University of Texas at San Antonio.

Wade, $M$.

2003 The Native Americans of the Texas Edwards Plateau, 1582-1799. Austin: The University of Texas Press.

Wallace, E.

1965 Texas in Turmoil: The Saga of Texas, 1849-1875. Austin: Steck-Vaughn.

Weber, D. L.

1992 The Spanish Frontier in North America. New Haven: Yale University Press.

Weddle, R. S.

1968 San Juan Bautista: Gateway to Spanish Texas. University of Texas Press, Austin.

Williams, A., G. Cohen, and J. S. Williams

2004 Reconstructing Majolica Patterns from Spanish Colonial Sites in Southern California. California Mission Studies Association Meetings, San Luis Obispo.

Yoakum, H. K.

1855 History of Texas from its First Settlement in 1685 to its Annexation to the United States in 1846. Vol II. Steck Company, Austin.

Zapata, J. E., M. J. Brown, and J. J. Durst

2000 Archaeological Excavation of the Priest Quarters, Mission San Francisco de la Espada, 41BX4, San Antonio, Texas. Archaeological Survey Report, No. 295. Center for Archaeological Research, The University of Texas at San Antonio. 


\section{Appendix A}

\section{Vertebrate Faunal Remains Recovered from 41BX1598}


Table A-1. Vertebrate Faunal Remains Recovered from 41BX1598

\begin{tabular}{|c|c|c|c|c|c|}
\hline Provenience & Zone & Lv. & Depth (cm) & Taxon & Count \\
\hline Backdirt & & & . & Bos taurus & 1 \\
\hline Backdirt & & & . & Bovinae & 2 \\
\hline Backdirt & & & . & Odocoileus virginianus & 1 \\
\hline Backdirt SW corner & & & . & Artiodactyl & 3 \\
\hline Backdirt SW corner & & & . & Bos taurus & 1 \\
\hline Backdirt SW corner & & & . & Bovinae & 13 \\
\hline Backdirt SW corner & & & . & Unidentified Mammal & 10 \\
\hline Backdirt SW corner & & & . & Vertebrata & 2 \\
\hline CPS Vault-Wall Fall & & & . & Bos taurus & 3 \\
\hline CPS Vault-Wall Fall & & & . & Odocoileus virginianus & 1 \\
\hline CPS Vault-Wall Fall & & & . & Unidentified Mammal & 4 \\
\hline MIdden area backdirt, upper level & & & . & Bovinae & 1 \\
\hline MIdden area backdirt, upper level & & & . & Unidentified Mammal & 8 \\
\hline Near Unit 7 & & & Surface & Bovinae & 2 \\
\hline Near Unit 7 & & & Surface & Caprinae & 1 \\
\hline Near Unit 7 & & & Surface & Unidentified Mammal & 2 \\
\hline ST 01 & & 1 & $0-10$ & Artiodactyl & 1 \\
\hline ST 01 & & 1 & $0-10$ & Unidentified Mammal & 4 \\
\hline ST 01 & & 4 & $30-40$ & Ovis aries & 1 \\
\hline ST 01 & & 4 & $30-40$ & Unidentified Mammal & 2 \\
\hline ST 01 & & 5 & $40-50$ & Unidentified Mammal & 8 \\
\hline ST 01 & & 6 & $50-60$ & Unidentified Mammal & 4 \\
\hline ST 01 & & 7 & $60-70$ & Unidentified Mammal & 5 \\
\hline ST 02 & & 1 & $0-10$ & Unidentified Mammal & 3 \\
\hline ST 02 & & 2 & $10-20$ & Unidentified Mammal & 2 \\
\hline ST 02 & & 3 & $20-30$ & Odocoileus virginianus & 1 \\
\hline ST 02 & & 4 & $30-40$ & Unidentified Mammal & 2 \\
\hline ST 02 & & 7 & $60-70$ & Artiodactyl & 1 \\
\hline ST 02 & & 7 & $60-70$ & Bovinae & 1 \\
\hline ST 02 & & 7 & $60-70$ & Unidentified Mammal & 3 \\
\hline ST 03 & & 1 & $0-10$ & Felis domesticus & 1 \\
\hline ST 03 & & 1 & $0-10$ & Unidentified Mammal & 8 \\
\hline ST 03 & & 3 & $20-30$ & Artiodactyl & 3 \\
\hline ST 03 & & 3 & $20-30$ & Canis sp. & 1 \\
\hline ST 03 & & 3 & $20-30$ & Caprinae & 1 \\
\hline ST 03 & & 3 & $20-30$ & Unidentified Mammal & 6 \\
\hline ST 03 & & 3 & $20-30$ & Unidentified Mammal & 122 \\
\hline ST 03 & & 4 & $30-40$ & Unidentified Mammal & 5 \\
\hline ST 03 & & 6 & $50-60$ & Unidentified Mammal & 3 \\
\hline ST 04 & & 1 & $0-10$ & Unidentified Mammal & 3 \\
\hline ST 04 & & 2 & $40-50$ & Bovinae & 1 \\
\hline ST 04 & & 2 & $10-20$ & Unidentified Mammal & 12 \\
\hline ST 04 & & 2 & $40-50$ & Unidentified Mammal & 9 \\
\hline ST 04 & & 3 & $20-30$ & Unidentified Mammal & 6 \\
\hline ST 04 & & 4 & $30-40$ & Unidentified Mammal & 1 \\
\hline ST 04 & & 6 & $50-60$ & Unidentified Mammal & 1 \\
\hline ST 04 & & 7 & $60-70$ & Unidentified Mammal & 2 \\
\hline
\end{tabular}


Table A-1. continued...

\begin{tabular}{|c|c|c|c|c|c|}
\hline Provenience & Zone & Lv. & Depth (cm) & Taxon & Count \\
\hline ST 05 & & 2 & $10-20$ & Unidentified Mammal & 2 \\
\hline ST 05 & & 4 & $30-40$ & Unidentified Mammal & 6 \\
\hline ST 05 & & 5 & $40-50$ & Unidentified Mammal & 8 \\
\hline ST 05 & & 6 & $50-60$ & Unidentified Mammal & 2 \\
\hline ST 05 & & 7 & $60-70$ & Bovinae & 1 \\
\hline$\overline{\text { ST } 05}$ & & 7 & $60-70$ & Unidentified Mammal & 4 \\
\hline ST 06 & & 3 & $20-30$ & Unidentified Mammal & 1 \\
\hline ST 06 & & 5 & $40-50$ & Unidentified Mammal & 2 \\
\hline ST 06 & & 6 & $50-60$ & Bos taurus & 1 \\
\hline ST 06 & & 6 & $50-60$ & Unidentified Bird & 1 \\
\hline ST 06 & & 6 & $50-60$ & Unidentified Mammal & 17 \\
\hline ST 06 & & 7 & $60-70$ & Unidentified Mammal & 10 \\
\hline ST 07 & & 1 & $0-10$ & Unidentified Mammal & 1 \\
\hline ST 07 & & 2 & $10-20$ & Unidentified Mammal & 3 \\
\hline ST 07 & & 4 & $30-40$ & Unidentified Mammal & 6 \\
\hline ST 07 & & 5 & $40-50$ & Bovinae & 2 \\
\hline$\overline{\text { ST } 07}$ & & 5 & $40-50$ & Unidentified Mammal & 12 \\
\hline $\begin{array}{ll}\text { ST } 07 \\
\end{array}$ & & 6 & $50-60$ & Unidentified Mammal & 3 \\
\hline$\overline{\text { ST } 07}$ & & 7 & $60-70$ & Unidentified Mammal & 3 \\
\hline ST 08 & & 1 & $0-10$ & Unidentified Mammal & 1 \\
\hline $\begin{array}{l}\text { ST } 08 \\
\end{array}$ & & 6 & $50-60$ & Artiodactyl & 1 \\
\hline $\begin{array}{l}\text { ST } 08 \\
\end{array}$ & & 6 & $50-60$ & Bovinae & 1 \\
\hline ST 08 & & 6 & $50-60$ & Unidentified Mammal & 11 \\
\hline $\begin{array}{l}\text { ST } 08 \\
\end{array}$ & & 7 & $60-70$ & Artiodactyl & 2 \\
\hline ST 08 & & 7 & $60-70$ & Unidentified Mammal & 7 \\
\hline ST 09 & & 1 & $0-10$ & Unidentified Mammal & 1 \\
\hline ST 09 & & 2 & $10-20$ & Unidentified Mammal & 3 \\
\hline Trench 3 & & & & cf. Bovinae & 1 \\
\hline Unidentified pit & & & & Artiodactyl & 1 \\
\hline Unidentified pit & & & & Bos taurus & 2 \\
\hline Unidentified pit & & & & Gallus gallus & 1 \\
\hline Unidentified pit & & & & Unidentified Bird & 5 \\
\hline Unidentified pit & & & & Unidentified Mammal & 1 \\
\hline Unit 1 & $n / a$ & 1 & $5-10$ & Lynx rufus & 1 \\
\hline \begin{tabular}{|l|l} 
Unit 1 \\
\end{tabular} & $n / a$ & 1 & $5-10$ & Unidentified Mammal & 12 \\
\hline \begin{tabular}{|l|l} 
Unit 1 \\
\end{tabular} & $n / a$ & 2 & $10-20$ & Bos taurus & 2 \\
\hline Unit 1 & $\mathrm{n} / \mathrm{a}$ & 2 & $10-20$ & Bovinae & 2 \\
\hline Unit 1 & $n / a$ & 2 & $10-20$ & Odocoileus virginianus & 1 \\
\hline Unit 1 & $\mathrm{n} / \mathrm{a}$ & 2 & $10-20$ & Unidentified Mammal & 41 \\
\hline Unit 1 & $\mathrm{n} / \mathrm{a}$ & 4 & $30-40$ & Artiodactyl & 4 \\
\hline Unit 1 & $\mathrm{n} / \mathrm{a}$ & 4 & $30-40$ & Bovinae & 1 \\
\hline$\overline{\text { Unit } 1}$ & $n / a$ & 4 & $30-40$ & Caprinae & 2 \\
\hline \begin{tabular}{|l|l} 
Unit 1 \\
\end{tabular} & $n / a$ & 4 & $30-40$ & Odocoileus virginianus & 2 \\
\hline Unit 1 & $n / a$ & 4 & $30-40$ & Unidentified Bird & 11 \\
\hline Unit 1 & $n / a$ & 4 & $30-40$ & \begin{tabular}{|l|} 
Unidentified Mammal \\
\end{tabular} & 194 \\
\hline$\overline{\text { Unit } 1}$ & $n / a$ & 5 & $40-50$ & Caprinae & 1 \\
\hline \begin{tabular}{|l} 
Unit 1 \\
\end{tabular} & $\mathrm{n} / \mathrm{a}$ & & $40-50$ & Gallus gallus & 2 \\
\hline
\end{tabular}


Table A-1. continued...

\begin{tabular}{|c|c|c|c|c|c|}
\hline Provenience & Zone & Lv. & Depth (cm) & Taxon & Count \\
\hline Unit 1 & $\mathrm{n} / \mathrm{a}$ & 5 & $40-50$ & Odocoileus virginianus & 2 \\
\hline Unit 1 & $\mathrm{n} / \mathrm{a}$ & 5 & $40-50$ & Ovis aries & 4 \\
\hline Unit 1 & $\mathrm{n} / \mathrm{a}$ & 5 & $40-50$ & Perciformes & 3 \\
\hline Unit 1 & $\mathrm{n} / \mathrm{a}$ & 5 & $40-50$ & Unidentified fish & 1 \\
\hline Unit 1 & $\mathrm{n} / \mathrm{a}$ & 6 & $50-60$ & Artiodactyl & 13 \\
\hline Unit 1 & $\mathrm{n} / \mathrm{a}$ & 6 & $50-60$ & Bison bison & 2 \\
\hline Unit 1 & $\mathrm{n} / \mathrm{a}$ & 6 & $50-60$ & Bovinae & 6 \\
\hline Unit 1 & $\mathrm{n} / \mathrm{a}$ & 6 & $50-60$ & Caprinae & 1 \\
\hline Unit 1 & $\mathrm{n} / \mathrm{a}$ & 6 & $50-60$ & Odocoileus virginianus & 4 \\
\hline Unit 1 & $\mathrm{n} / \mathrm{a}$ & 6 & $50-60$ & Unidentified Bird & 4 \\
\hline Unit 1 & $\mathrm{n} / \mathrm{a}$ & 6 & $50-60$ & Unidentified Mammal & 216 \\
\hline Unit 1 & $\mathrm{n} / \mathrm{a}$ & 7 & $60-70$ & Artiodactyl & 3 \\
\hline Unit 1 & $\mathrm{n} / \mathrm{a}$ & 7 & $60-70$ & Bison bison & 2 \\
\hline Unit 1 & $\mathrm{n} / \mathrm{a}$ & 7 & $60-70$ & Bovinae & 4 \\
\hline Unit 1 & $n / a$ & 7 & $60-70$ & Odocoileus virginianus & 2 \\
\hline Unit 1 & $n / a$ & 7 & $60-70$ & Testudines & 1 \\
\hline Unit 1 & $n / a$ & 7 & $60-70$ & Unidentified Bird & 5 \\
\hline Unit 1 & $\mathrm{n} / \mathrm{a}$ & 7 & $60-70$ & Unidentified Mammal & 164 \\
\hline Unit 1 & $\mathrm{n} / \mathrm{a}$ & 8 & $70-85$ & Artiodactyl & 1 \\
\hline Unit 1 & $\mathrm{n} / \mathrm{a}$ & 8 & $70-85$ & Bovinae & 4 \\
\hline Unit 1 & $\mathrm{n} / \mathrm{a}$ & 8 & $70-85$ & Caprinae & 1 \\
\hline Unit 1 & $\mathrm{n} / \mathrm{a}$ & 8 & $70-85$ & Equus caballos & 1 \\
\hline Unit 1 & $n / a$ & 8 & $70-85$ & Ictalurus sp. & 1 \\
\hline Unit 1 & $\mathrm{n} / \mathrm{a}$ & 8 & $70-85$ & Unidentified Bird & 7 \\
\hline Unit 1 & $\mathrm{n} / \mathrm{a}$ & 8 & $70-85$ & Unidentified fish & 1 \\
\hline Unit 1 & $\mathrm{n} / \mathrm{a}$ & 8 & $70-85$ & Unidentified Mammal & 144 \\
\hline Unit 1 & $\mathrm{n} / \mathrm{a}$ & 9 & $85-93$ & Artiodactyl & 1 \\
\hline Unit 1 & $\mathrm{n} / \mathrm{a}$ & 9 & $85-93$ & Bos taurus & 1 \\
\hline Unit 1 & $\mathrm{n} / \mathrm{a}$ & 9 & $85-93$ & Bovinae & 2 \\
\hline Unit 1 & $\mathrm{n} / \mathrm{a}$ & 9 & $85-93$ & Unidentified Mammal & 44 \\
\hline Unit 1 Wall scraping & & & & Artiodactyl & 4 \\
\hline Unit 1 Wall scraping & & & & Bos taurus & 2 \\
\hline Unit 1 Wall scraping & & & . & Bovinae & 5 \\
\hline Unit 1 Wall scraping & & & $\mid$ & Ovis aries & 2 \\
\hline Unit 1 Wall scraping & & & . & Unidentified Bird & 2 \\
\hline Unit 1 Wall scraping & & & & Unidentified Mammal & 157 \\
\hline Unit 2 & $\mathrm{n} / \mathrm{a}$ & 1 & $11-15$ & Artiodactyl & 7 \\
\hline Unit 2 & $\mathrm{n} / \mathrm{a}$ & 1 & $11-15$ & Bos taurus & 2 \\
\hline Unit 2 & $\mathrm{n} / \mathrm{a}$ & 1 & $11-15$ & Bovinae & 7 \\
\hline Unit 2 & $\mathrm{n} / \mathrm{a}$ & 1 & $11-15$ & Unidentified Bird & 11 \\
\hline Unit 2 & $n / a$ & 1 & $11-15$ & Unidentified Mammal & 475 \\
\hline Unit 2 & $\mathrm{n} / \mathrm{a}$ & 2 & $15-25$ & Artiodactyl & 9 \\
\hline Unit 2 & $\mathrm{n} / \mathrm{a}$ & 2 & $15-25$ & Bos taurus & 5 \\
\hline Unit 2 & $\mathrm{n} / \mathrm{a}$ & 2 & $15-25$ & Bovinae & 19 \\
\hline Unit 2 & $\mathrm{n} / \mathrm{a}$ & 2 & $15-25$ & Capra hircus & 1 \\
\hline Unit 2 & $\mathrm{n} / \mathrm{a}$ & 2 & $15-25$ & Caprinae & 3 \\
\hline Unit 2 & $\mathrm{n} / \mathrm{a}$ & 2 & $15-25$ & Unidentified Bird & 3 \\
\hline Unit 2 & $\mathrm{n} / \mathrm{a}$ & 2 & $15-25$ & Unidentified Fish & 1 \\
\hline
\end{tabular}


Table A-1. continued...

\begin{tabular}{|c|c|c|c|c|c|}
\hline Provenience & Zone & Lv. & Depth (cm) & Taxon & Count \\
\hline Unit 2 & $\mathrm{n} / \mathrm{a}$ & 2 & $15-25$ & Unidentified Mammal & 498 \\
\hline Unit 2 & $\mathrm{n} / \mathrm{a}$ & 3 & $25-35$ & Artiodactyl & 6 \\
\hline Unit 2 & $\mathrm{n} / \mathrm{a}$ & 3 & $25-35$ & Bison bison & 1 \\
\hline Unit 2 & $\mathrm{n} / \mathrm{a}$ & 3 & $25-35$ & Bovinae & 7 \\
\hline Unit 2 & $\mathrm{n} / \mathrm{a}$ & 3 & $25-35$ & Canis sp. & 1 \\
\hline Unit 2 & $\mathrm{n} / \mathrm{a}$ & 3 & $25-35$ & Odocoileus virginianus & 5 \\
\hline Unit 2 & $\mathrm{n} / \mathrm{a}$ & 3 & $25-35$ & Unidentified Mammal & 331 \\
\hline Unit 2 & $\mathrm{n} / \mathrm{a}$ & 4 & $35-45$ & Antilocapra americana & 1 \\
\hline Unit 2 & $\mathrm{n} / \mathrm{a}$ & 4 & $35-45$ & Artiodactyl & 3 \\
\hline Unit 2 & $\mathrm{n} / \mathrm{a}$ & 4 & $35-45$ & Bos taurus & 3 \\
\hline Unit 2 & $\mathrm{n} / \mathrm{a}$ & 4 & $35-45$ & Bovinae & 12 \\
\hline Unit 2 & $\mathrm{n} / \mathrm{a}$ & 4 & $35-45$ & Caprinae & 1 \\
\hline Unit 2 & $\mathrm{n} / \mathrm{a}$ & 4 & $35-45$ & Gallus gallus & 3 \\
\hline Unit 2 & n/a & 4 & $35-45$ & Odocoileus virginianus & 1 \\
\hline Unit 2 & $\mathrm{n} / \mathrm{a}$ & 4 & $35-45$ & Ovis aries & $\overline{1}$ \\
\hline Unit 2 & $\mathrm{n} / \mathrm{a}$ & 4 & $35-45$ & Pecari tajacu & 2 \\
\hline Unit 2 & $\mathrm{n} / \mathrm{a}$ & 4 & $35-45$ & Unidentified Bird & 2 \\
\hline Unit 2 & $\mathrm{n} / \mathrm{a}$ & 4 & $35-45$ & Unidentified Mammal & 23 \\
\hline Unit 2 & $\mathrm{n} / \mathrm{a}$ & 4 & $35-45$ & Unidentified Mammal & 268 \\
\hline Unit 2 & $\mathrm{n} / \mathrm{a}$ & 5 & $45-55$ & Artiodactyl & 10 \\
\hline Unit 2 & $\mathrm{n} / \mathrm{a}$ & 5 & $45-55$ & Bison bison & 2 \\
\hline Unit 2 & $\mathrm{n} / \mathrm{a}$ & 5 & $45-55$ & Bos taurus & 5 \\
\hline Unit 2 & $\mathrm{n} / \mathrm{a}$ & 5 & $45-55$ & Bovinae & 3 \\
\hline Unit 2 & $\mathrm{n} / \mathrm{a}$ & 5 & $45-55$ & Odocoileus virginianus & 2 \\
\hline Unit 2 & $\mathrm{n} / \mathrm{a}$ & 5 & $45-55$ & Unidentified Mammal & 186 \\
\hline Unit 2 & $\mathrm{n} / \mathrm{a}$ & 6 & $55-65$ & Artiodactyl & 2 \\
\hline Unit 2 & $\mathrm{n} / \mathrm{a}$ & 6 & $55-65$ & Bison bison & 2 \\
\hline Unit 2 & $\mathrm{n} / \mathrm{a}$ & 6 & $55-65$ & Bos taurus & 4 \\
\hline Unit 2 & $\mathrm{n} / \mathrm{a}$ & 6 & $55-65$ & Bovinae & 14 \\
\hline Unit 2 & $\mathrm{n} / \mathrm{a}$ & 6 & $55-65$ & Bovinae & 3 \\
\hline Unit 2 & $\mathrm{n} / \mathrm{a}$ & 6 & $55-65$ & Gallus gallus & 1 \\
\hline Unit 2 & $\mathrm{n} / \mathrm{a}$ & 6 & $55-65$ & Odocoileus virginianus & 1 \\
\hline Unit 2 & $\mathrm{n} / \mathrm{a}$ & 6 & $55-65$ & Unidentified Mammal & 107 \\
\hline Unit 2 & $\mathrm{n} / \mathrm{a}$ & 6 & $55-65$ & Unidentified Mammal & 209 \\
\hline Unit 2 & $\mathrm{n} / \mathrm{a}$ & 6 & $55-65$ & Vertebrata & 2 \\
\hline Unit 2 & $\mathrm{n} / \mathrm{a}$ & 7 & $65-75$ & Unidentified Mammal & 1 \\
\hline Unit 2 & $\mathrm{n} / \mathrm{a}$ & 8 & $75-84$ & Bovinae & 4 \\
\hline Unit 2 & $\mathrm{n} / \mathrm{a}$ & 8 & $75-84$ & Lepus californicus & 2 \\
\hline Unit 2 & $\mathrm{n} / \mathrm{a}$ & 8 & 75-84 & Odocoileus virginianus & 1 \\
\hline Unit 2 & $\mathrm{n} / \mathrm{a}$ & 8 & 75-84 & Unidentified Mammal & 53 \\
\hline Unit 3 & $\mathrm{n} / \mathrm{a}$ & 1 & $0-10$ & Unidentified Mammal & 2 \\
\hline Unit 3 & $\mathrm{n} / \mathrm{a}$ & 2 & $10-20$ & Unidentified Mammal & 1 \\
\hline Unit 3 & $\mathrm{n} / \mathrm{a}$ & 3 & $20-30$ & Unidentified Mammal & 3 \\
\hline Unit 3 & $\mathrm{n} / \mathrm{a}$ & 5 & $40-50$ & Unidentified Mammal & 3 \\
\hline Unit 4 & 1 & 1 & $0-10$ & Odocoileus virginianus & 1 \\
\hline Unit 4 & 1 & 1 & $0-10$ & Unidentified Mammal & 13 \\
\hline Unit 4 & 1 & 2 & $10-20$ & Artiodactyl & 1 \\
\hline Unit 4 & 1 & 2 & $10-20$ & Unidentified Bird & 1 \\
\hline
\end{tabular}


Table A-1. continued...

\begin{tabular}{|c|c|c|c|c|c|}
\hline Provenience & Zone & Lv. & Depth (cm) & Taxon & Count \\
\hline \begin{tabular}{|l|} 
Unit 4 \\
\end{tabular} & 1 & 2 & $10-20$ & Unidentified Fish & 1 \\
\hline Unit 4 & 1 & 2 & $10-20$ & Unidentified Mammal & 24 \\
\hline Unit 4 & 1 & 3 & $20-30$ & Artiodactyl & 1 \\
\hline Unit 4 & 1 & 3 & $20-30$ & Ovis aries & 5 \\
\hline Unit 4 & 1 & 3 & $20-30$ & Unidentified Bird & 2 \\
\hline Unit 4 & 1 & 3 & $20-30$ & Unidentified Mammal & 79 \\
\hline Unit 4 & 2 & 1 & $29-30$ & Artiodactyl & 7 \\
\hline Unit 4 & 2 & 1 & $29-30$ & Bovinae & 3 \\
\hline Unit 4 & 2 & 1 & $29-30$ & Canis sp. & 1 \\
\hline Unit 4 & 2 & 1 & $29-30$ & Gallus gallus & 3 \\
\hline Unit 4 & 2 & 1 & $29-30$ & Odocoileus virginianus & 1 \\
\hline Unit 4 & 2 & 1 & $29-30$ & Unidentified Bird & 3 \\
\hline Unit 4 & 2 & 1 & $29-30$ & Unidentified Mammal & 145 \\
\hline Unit 4 & 4 & 1 & $45-55$ & Artiodactyl & 4 \\
\hline Unit 4 & 4 & 1 & $45-55$ & Bovinae & 8 \\
\hline Unit 4 & 4 & 1 & $45-55$ & Pecari tajacu & 4 \\
\hline Unit 4 & 4 & 1 & $45-55$ & Rodentia & 1 \\
\hline Unit 4 & 4 & 1 & $45-55$ & Unidentified Bird & 8 \\
\hline Unit 4 & 4 & 1 & $45-55$ & Unidentified fish & 1 \\
\hline Unit 4 & 4 & 1 & $45-55$ & Unidentified Mammal & 244 \\
\hline Unit 4 & 4 & 2 & $55-65$ & Artiodactyl & 7 \\
\hline Unit 4 & 4 & 2 & $55-65$ & Artiodactyl & 5 \\
\hline Unit 4 & 4 & 2 & $55-65$ & Bovinae & 3 \\
\hline Unit 4 & 4 & 2 & $55-65$ & Bovinae & 3 \\
\hline Unit 4 & 4 & 2 & $55-65$ & Canis sp. & 1 \\
\hline Unit 4 & 4 & 2 & $55-65$ & Odocoileus virginianus & 3 \\
\hline Unit 4 & 4 & 2 & $55-65$ & Testudines & 1 \\
\hline Unit 4 & 4 & 2 & $55-65$ & Unidentified Bird & 7 \\
\hline Unit 4 & 4 & 2 & $55-65$ & Unidentified Mammal & 466 \\
\hline Unit 4 & 4 & 2 & $55-65$ & Unidentified Mammal & 197 \\
\hline Unit 4 & 5 & 1 & $65-75$ & Artiodactyl & 13 \\
\hline Unit 4 & 5 & 1 & $65-75$ & Bos taurus & 6 \\
\hline Unit 4 & 5 & 1 & $65-75$ & Bovinae & 24 \\
\hline Unit 4 & 5 & 1 & $65-75$ & Branta sp. & 1 \\
\hline Unit 4 & 5 & 1 & $65-75$ & Canis sp. & 1 \\
\hline Unit 4 & 5 & 1 & $65-75$ & Equus sp. & 1 \\
\hline Unit 4 & 5 & 1 & $65-75$ & Gallus gallus & 1 \\
\hline Unit 4 & 5 & 1 & $65-75$ & Ovis aries & 1 \\
\hline Unit 4 & 5 & 1 & $65-75$ & Testudines & 1 \\
\hline Unit 4 & 5 & 1 & $65-75$ & Unidentified Bird & 11 \\
\hline Unit 4 & 5 & 1 & $65-75$ & Unidentified fish & 1 \\
\hline Unit 4 & 5 & 1 & $65-75$ & Unidentified Mammal & 360 \\
\hline Unit 4 & 5 & 2 & $75-85$ & Artiodactyl & 7 \\
\hline Unit 4 & 5 & 2 & $75-85$ & Bison bison & 7 \\
\hline Unit 4 & 5 & 2 & $75-85$ & Bovinae & 36 \\
\hline Unit 4 & 5 & 2 & $75-85$ & Caprinae & 1 \\
\hline Unit 4 & 5 & 2 & $75-85$ & Cathartes aura & 1 \\
\hline Unit 4 & 5 & 2 & $75-85$ & Emydidae & 1 \\
\hline
\end{tabular}


Table A-1. continued...

\begin{tabular}{|c|c|c|c|c|c|}
\hline Provenience & Zone & Lv. & Depth (cm) & Taxon & Count \\
\hline Unit 4 & 5 & 2 & $75-85$ & Ictalurus sp. & 1 \\
\hline Unit 4 & 5 & 2 & $75-85$ & Meleagris gallopavo & 3 \\
\hline Unit 4 & 5 & 2 & $75-85$ & Ovis aries & 4 \\
\hline Unit 4 & 5 & 2 & $75-85$ & Unidentified Bird & 4 \\
\hline Unit 4 & 5 & 2 & $75-85$ & Unidentified Mammal & 498 \\
\hline Unit 4 & 5 & 3 & $85-88$ & Artiodactyl & 7 \\
\hline Unit 4 & 5 & 3 & $85-88$ & Bos taurus & 7 \\
\hline Unit 4 & 5 & 3 & $85-88$ & Bovinae & 26 \\
\hline Unit 4 & 5 & 3 & $85-88$ & Meleagris gallopavo & 2 \\
\hline Unit 4 & 5 & 3 & $85-88$ & Unidentified Mammal & 216 \\
\hline Unit 4 & 6 & 1 & $88-98$ & Artiodactyl & 3 \\
\hline Unit 4 & 6 & 1 & $88-98$ & Bovinae & 6 \\
\hline Unit 4 & 6 & 1 & $88-98$ & Ovis aries & 1 \\
\hline Unit 4 & 6 & 1 & $88-98$ & Unidentified Mammal & 65 \\
\hline Unit 4 & 7 & 1 & $98-108$ & Ictalurus sp. & 1 \\
\hline Unit 4 & 7 & 1 & $98-108$ & Unidentified Mammal & 18 \\
\hline Unit 4 & 7 & 1 & $98-108$ & Artiodactyl & 13 \\
\hline Unit 4 & 7 & 1 & $98-108$ & Bison bison & 7 \\
\hline Unit 4 & 7 & 1 & $98-108$ & Bos taurus & 30 \\
\hline Unit 4 & 7 & 1 & $98-108$ & Bovinae & 51 \\
\hline Unit 4 & 7 & 1 & $98-108$ & Odocoileus virginianus & 3 \\
\hline Unit 4 & 7 & 1 & $98-108$ & Unidentified Bird & 3 \\
\hline Unit 4 & 7 & 1 & $98-108$ & Unidentified Mammal & 410 \\
\hline Unit 4 & 7 & 2 & $98-108$ & Antilocapra americana & 2 \\
\hline Unit 4 & 7 & 2 & $98-108$ & Artiodactyl & 3 \\
\hline Unit 4 & 7 & 2 & $98-108$ & Bison bison & 6 \\
\hline Unit 4 & 7 & 2 & $98-108$ & Bos taurus & 17 \\
\hline Unit 4 & 7 & 2 & $98-108$ & Bovinae & 53 \\
\hline Unit 4 & 7 & 2 & $98-108$ & Canis sp. & 2 \\
\hline Unit 4 & 7 & 2 & $98-108$ & Meleagris gallopavo & 1 \\
\hline Unit 4 & 7 & 2 & $98-108$ & Unidentified Bird & 2 \\
\hline Unit 4 & 7 & 2 & $98-108$ & Unidentified Mammal & 428 \\
\hline Unit 4 & 8 & 1 & $118-128$ & Artiodactyl & 1 \\
\hline Unit 4 & 8 & 1 & $118-128$ & Bison bison & 2 \\
\hline Unit 4 & 8 & 1 & $118-128$ & Bovinae & 3 \\
\hline Unit 4 & 8 & 1 & $118-128$ & Caprinae & 1 \\
\hline Unit 4 & 8 & 1 & $118-128$ & Unidentified Bird & 1 \\
\hline Unit 4 & 8 & 1 & $118-128$ & Unidentified Mammal & 52 \\
\hline Unit 5 & 1 & 1 & $0-10$ & Bovinae & 1 \\
\hline Unit 5 & 1 & 1 & $0-10$ & Unidentified Bird & 3 \\
\hline Unit 5 & 1 & 1 & $0-10$ & Unidentified Mammal & 44 \\
\hline Unit 5 & 1 & 2 & $10-20$ & Artiodactyl & 1 \\
\hline Unit 5 & 1 & 2 & $10-20$ & Bovinae & 3 \\
\hline Unit 5 & 1 & 2 & $10-20$ & Pecari tajacu & 2 \\
\hline Unit 5 & 1 & 2 & $10-20$ & Unidentified Bird & 2 \\
\hline Unit 5 & 1 & 2 & $10-20$ & Unidentified Mammal & 75 \\
\hline Unit 5 & 1 & 2 & $10-20$ & Unidentified Mammal & 14 \\
\hline Unit 5 & 2 & 1 & $20-25$ & Artiodactyl & 4 \\
\hline
\end{tabular}


Table A-1. continued...

\begin{tabular}{|c|c|c|c|c|c|}
\hline Provenience & Zone & Lv. & Depth (cm) & \begin{tabular}{|l} 
Taxon \\
\end{tabular} & Count \\
\hline \begin{tabular}{|l} 
Unit 5 \\
\end{tabular} & 2 & 1 & $20-25$ & Bos taurus & 1 \\
\hline Unit 5 & 2 & 1 & $20-25$ & Odocoileus virginianus & 1 \\
\hline Unit 5 & 2 & & 24 & Artiodactyl & 2 \\
\hline Unit 5 & 2 & 3 & 24 & Unidentified Mammal & 67 \\
\hline Unit 5 & 3 & 1 & $35-45$ & Artiodactyl & 2 \\
\hline Unit 5 & 3 & 1 & $35-45$ & Bovinae & 3 \\
\hline Unit 5 & 3 & 1 & $20-25$ & Buteo sp. & 1 \\
\hline Unit 5 & 3 & 1 & $35-45$ & Canis sp. & 1 \\
\hline Unit 5 & 3 & 1 & $20-25$ & Unidentified Mammal & 181 \\
\hline Unit 5 & 3 & 1 & $35-45$ & Unidentified Mammal & 95 \\
\hline Unit 5 & 3 & 2 & $25-30$ & Bos taurus & 1 \\
\hline Unit 5 & 3 & 2 & $25-30$ & Bovinae & 1 \\
\hline Unit 5 & 3 & 2 & $25-30$ & Unidentified Mammal & 87 \\
\hline Unit 5 & 3 & 3 & $30-35$ & Artiodactyl & 2 \\
\hline Unit 5 & 3 & 3 & $30-35$ & Bovinae & 3 \\
\hline Unit 5 & 3 & 3 & $30-35$ & Unidentified Mammal & 70 \\
\hline Unit 5 & 4 & 1 & $25-30$ & Artiodactyl & 1 \\
\hline Unit 5 & 4 & 1 & $25-30$ & Bos taurus & 1 \\
\hline Unit 5 & 4 & 1 & $25-30$ & Bovinae & 4 \\
\hline Unit 5 & 4 & 1 & $25-30$ & Gallus gallus & 1 \\
\hline Unit 5 & 4 & 1 & $25-30$ & Odocoileus virginianus & 1 \\
\hline Unit 5 & 4 & 1 & $25-30$ & Unidentified Bird & 9 \\
\hline Unit 5 & 4 & 1 & $25-30$ & Unidentified fish & 5 \\
\hline Unit 5 & 4 & 1 & $25-30$ & Unidentified Mammal & 124 \\
\hline Unit 5 & 4 & 2 & $30-35$ & Artiodactyl & 2 \\
\hline Unit 5 & 4 & 2 & $30-35$ & Bos taurus & 1 \\
\hline Unit 5 & 4 & 2 & $30-35$ & Bovinae & 7 \\
\hline Unit 5 & 4 & 2 & $30-35$ & Caprinae & 7 \\
\hline Unit 5 & 4 & 2 & $30-35$ & Sus scrofa & 1 \\
\hline Unit 5 & 4 & 2 & $30-35$ & Unidentified Mammal & 183 \\
\hline Unit 5 & 4 & 3 & $35-40$ & Artiodactyl & 6 \\
\hline Unit 5 & 4 & 3 & $35-40$ & Bos taurus & 1 \\
\hline Unit 5 & 4 & 3 & $35-40$ & Bovinae & 12 \\
\hline Unit 5 & 4 & 3 & $35-40$ & Capra hircus & 1 \\
\hline Unit 5 & 4 & 3 & $35-40$ & Caprinae & 1 \\
\hline Unit 5 & 4 & 3 & $35-40$ & Unidentified Bird & 3 \\
\hline Unit 5 & 4 & 3 & $35-40$ & Unidentified fish & 1 \\
\hline Unit 5 & 4 & 3 & $35-40$ & Unidentified Mammal & 326 \\
\hline Unit 5 & 4 & 3 & $35-40$ & Unidentified Mammal & 38 \\
\hline Unit 5 & 5 & 1 & $40-45$ & Artiodactyl & 10 \\
\hline Unit 5 & 5 & 1 & $40-45$ & Bos taurus & 1 \\
\hline Unit 5 & 5 & 1 & $40-45$ & Bovinae & 8 \\
\hline Unit 5 & 5 & 1 & $40-45$ & Caprinae & 2 \\
\hline Unit 5 & 5 & 1 & $40-45$ & Equus sp. & 1 \\
\hline Unit 5 & 5 & 1 & $40-45$ & Odocoileus virginianus & 1 \\
\hline Unit 5 & 5 & 1 & $40-45$ & Unidentified Bird & 1 \\
\hline Unit 5 & 5 & 1 & $40-45$ & Unidentified Bird & 1 \\
\hline Unit 5 & 5 & 1 & $40-45$ & Unidentified Mammal & 373 \\
\hline
\end{tabular}


Table A-1. continued...

\begin{tabular}{|c|c|c|c|c|c|}
\hline Provenience & Zone & Lv. & Depth (cm) & Taxon & Count \\
\hline Unit 5 & 5 & 1 & $40-45$ & Unidentified Mammal & 9 \\
\hline Unit 5 & 5 & 2 & $45-50$ & Artiodactyl & 12 \\
\hline Unit 5 & 5 & 2 & $45-50$ & Bos taurus & 3 \\
\hline Unit 5 & 5 & 2 & $45-50$ & Bovinae & 34 \\
\hline Unit 5 & 5 & 2 & $45-50$ & Equus sp. & 1 \\
\hline Unit 5 & 5 & 2 & $45-50$ & Gallus gallus & 1 \\
\hline Unit 5 & 5 & 2 & $45-50$ & Ovis aries & 1 \\
\hline Unit 5 & 5 & 2 & $45-50$ & Pecari tajacu & 2 \\
\hline Unit 5 & 5 & 2 & $45-50$ & Sus scrofa & 2 \\
\hline Unit 5 & 5 & 2 & $45-50$ & Unidentified Mammal & 767 \\
\hline Unit 5 & 5 & 3 & $50-55$ & Artiodactyl & 6 \\
\hline Unit 5 & 5 & 3 & $50-55$ & Bison bison & 1 \\
\hline Unit 5 & 5 & 3 & $50-55$ & Bos taurus & 4 \\
\hline Unit 5 & 5 & 3 & $50-55$ & Bovinae & 32 \\
\hline Unit 5 & 5 & 3 & $50-55$ & Gallus gallus & 1 \\
\hline Unit 5 & 5 & 3 & $50-55$ & Ictalurus sp. & 1 \\
\hline Unit 5 & 5 & 3 & $50-55$ & Odocoileus virginianus & 1 \\
\hline Unit 5 & 5 & 3 & $50-55$ & Ovis aries & 4 \\
\hline Unit 5 & 5 & 3 & $50-55$ & Sus scrofa & 5 \\
\hline Unit 5 & 5 & 3 & $50-55$ & Unidentified fish & 2 \\
\hline Unit 5 & 5 & 3 & $50-55$ & Unidentified Mammal & 567 \\
\hline Unit 5 & 6 & 1 & $55-60$ & Artiodactyl & 1 \\
\hline Unit 5 & 6 & 1 & $55-60$ & Bos taurus & 4 \\
\hline Unit 5 & 6 & 1 & $55-60$ & Bovinae & 5 \\
\hline Unit 5 & 6 & 1 & $55-60$ & Caprinae & 6 \\
\hline Unit 5 & 6 & 1 & $55-60$ & Pylodictus olivaris & 1 \\
\hline Unit 5 & 6 & 1 & $55-60$ & Sus scrofa & 1 \\
\hline Unit 5 & 6 & 1 & $55-60$ & Unidentified Mammal & 95 \\
\hline Unit 5 & 6 & 2 & $60-65$ & Artiodactyl & 5 \\
\hline Unit 5 & 6 & 2 & $60-65$ & Bovinae & 10 \\
\hline Unit 5 & 6 & 2 & $60-65$ & Unidentified Bird & 3 \\
\hline Unit 5 & 6 & 2 & $60-65$ & Unidentified Mammal & 130 \\
\hline Unit 5 & 7 & 1 & $65-70$ & Artiodactyl & 3 \\
\hline Unit 5 & 7 & 1 & $65-70$ & Bos taurus & 1 \\
\hline Unit 5 & 7 & 1 & $65-70$ & Bovinae & 14 \\
\hline Unit 5 & 7 & 1 & $65-70$ & Odocoileus virginianus & 2 \\
\hline Unit 5 & 7 & 1 & $65-70$ & Unidentified Bird & 3 \\
\hline Unit 5 & 7 & 1 & $65-70$ & Unidentified Mammal & 255 \\
\hline Unit 5 & 7 & 1 & $65-70$ & Unidentified Mammal & 32 \\
\hline Unit 5 & 7 & 2 & $70-75$ & Bos taurus & 2 \\
\hline Unit 5 & 7 & 2 & $70-75$ & Bovinae & 13 \\
\hline Unit 5 & 7 & 2 & $70-75$ & Ovis aries & 2 \\
\hline Unit 5 & 7 & 2 & $70-75$ & Sus scrofa & 1 \\
\hline Unit 5 & 7 & 2 & $70-75$ & Unidentified Mammal & 122 \\
\hline Unit 5 & 8 & 1 & $75-81$ & Artiodactyl & 4 \\
\hline Unit 5 & 8 & 1 & $75-81$ & Bovinae & 4 \\
\hline Unit 5 & 8 & 1 & $75-81$ & Unidentified Mammal & 111 \\
\hline Unit 5 & 8 & 1 & $75-81$ & Unidentified Mammal & 1 \\
\hline
\end{tabular}


Table A-1. continued...

\begin{tabular}{|c|c|c|c|c|c|}
\hline Provenience & Zone & Lv. & Depth (cm) & Taxon & Count \\
\hline Unit 6 & $\mathrm{n} / \mathrm{a}$ & 1 & $0-10$ & Artiodactyl & 22 \\
\hline Unit 6 & $\mathrm{n} / \mathrm{a}$ & 1 & $0-10$ & Gallus gallus & 1 \\
\hline Unit 6 & $\mathrm{n} / \mathrm{a}$ & 1 & $0-10$ & Unidentified Bird & 11 \\
\hline Unit 6 & $\mathrm{n} / \mathrm{a}$ & 1 & $0-10$ & Unidentified Mammal & 189 \\
\hline Unit 6 & $\mathrm{n} / \mathrm{a}$ & 2 & $10-20$ & Artiodactyl & 19 \\
\hline Unit 6 & $\mathrm{n} / \mathrm{a}$ & 2 & $10-20$ & Bovinae & 8 \\
\hline Unit 6 & $\mathrm{n} / \mathrm{a}$ & 2 & $10-20$ & Caprinae & 8 \\
\hline Unit 6 & $\mathrm{n} / \mathrm{a}$ & 2 & $10-20$ & Gallus gallus & 2 \\
\hline Unit 6 & $\mathrm{n} / \mathrm{a}$ & 2 & $10-20$ & Meleagris gallopavo & 1 \\
\hline Unit 6 & $\mathrm{n} / \mathrm{a}$ & 2 & $10-20$ & Unidentified Mammal & 336 \\
\hline Unit 6 & $\mathrm{n} / \mathrm{a}$ & 3 & $20-30$ & Artiodactyl & 7 \\
\hline Unit 6 & $\mathrm{n} / \mathrm{a}$ & 3 & $20-30$ & Bison bison & 3 \\
\hline Unit 6 & $\mathrm{n} / \mathrm{a}$ & 3 & $20-30$ & Bovinae & 4 \\
\hline Unit 6 & $\mathrm{n} / \mathrm{a}$ & 3 & $20-30$ & Odocoileus virginianus & 1 \\
\hline Unit 6 & $\mathrm{n} / \mathrm{a}$ & 3 & $20-30$ & Sus scrofa & 1 \\
\hline Unit 6 & $\mathrm{n} / \mathrm{a}$ & 3 & $20-30$ & Testudines & 1 \\
\hline Unit 6 & $\mathrm{n} / \mathrm{a}$ & 3 & $20-30$ & Unidentified Bird & 2 \\
\hline Unit 6 & $\mathrm{n} / \mathrm{a}$ & 3 & $20-30$ & Unidentified Mammal & 165 \\
\hline Unit 6 & $\mathrm{n} / \mathrm{a}$ & 4 & $30-40$ & Artiodactyl & 1 \\
\hline Unit 6 & $\mathrm{n} / \mathrm{a}$ & 4 & $30-40$ & Bovinae & 3 \\
\hline Unit 6 & $\mathrm{n} / \mathrm{a}$ & 4 & $30-40$ & Unidentified Mammal & 92 \\
\hline Unit 6 & $\mathrm{n} / \mathrm{a}$ & 5 & $40-50$ & Artiodactyl & 10 \\
\hline Unit 6 & $\mathrm{n} / \mathrm{a}$ & 5 & $40-50$ & Bos taurus & 1 \\
\hline Unit 6 & $\mathrm{n} / \mathrm{a}$ & 5 & $40-50$ & Bovinae & 8 \\
\hline Unit 6 & $\mathrm{n} / \mathrm{a}$ & 5 & $40-50$ & Caprinae & 1 \\
\hline Unit 6 & $\mathrm{n} / \mathrm{a}$ & 5 & $40-50$ & Odocoileus virginianus & 1 \\
\hline Unit 6 & $\mathrm{n} / \mathrm{a}$ & 5 & $40-50$ & Unidentified Bird & 7 \\
\hline Unit 6 & $\mathrm{n} / \mathrm{a}$ & 5 & $10-20$ & Unidentified Mammal & 18 \\
\hline Unit 6 & $\mathrm{n} / \mathrm{a}$ & 5 & $40-50$ & Unidentified Mammal & 66 \\
\hline Unit 6 & $\mathrm{n} / \mathrm{a}$ & 6 & $50-56$ & Odocoileus virginianus & 3 \\
\hline Unit 6 & $\mathrm{n} / \mathrm{a}$ & 6 & $50-56$ & Unidentified Bird & 1 \\
\hline Unit 6 & $\mathrm{n} / \mathrm{a}$ & 6 & $50-56$ & Unidentified Mammal & 26 \\
\hline Unit 6 & $\mathrm{n} / \mathrm{a}$ & 7 & $56-60$ & Unidentified Bird & 1 \\
\hline Unit 6 & $\mathrm{n} / \mathrm{a}$ & 8 & $60-62$ & Artiodactyl & 1 \\
\hline Unit 6 & $\mathrm{n} / \mathrm{a}$ & 8 & $60-62$ & Sus scrofa & 1 \\
\hline Unit 6 & $\mathrm{n} / \mathrm{a}$ & 9 & $62-70$ & Artiodactyl & 3 \\
\hline Unit 6 & $\mathrm{n} / \mathrm{a}$ & 9 & $62-70$ & Unidentified Bird & 4 \\
\hline Unit 6 & $\mathrm{n} / \mathrm{a}$ & 9 & $62-70$ & Unidentified Mammal & 23 \\
\hline Unit 6 & $\mathrm{n} / \mathrm{a}$ & 10 & $70-80$ & Unidentified Bird & 5 \\
\hline Unit 6 & $\mathrm{n} / \mathrm{a}$ & 10 & $70-80$ & Unidentified Mammal & 33 \\
\hline Unit 6 & $\mathrm{n} / \mathrm{a}$ & 11 & $80-90$ & Artiodactyl & 2 \\
\hline Unit 6 & $\mathrm{n} / \mathrm{a}$ & 11 & $80-90$ & Gallus gallus & 1 \\
\hline Unit 6 & $\mathrm{n} / \mathrm{a}$ & 11 & $80-90$ & Unidentified Bird & 1 \\
\hline Unit 6 & $\mathrm{n} / \mathrm{a}$ & 11 & $80-90$ & Unidentified Mammal & 40 \\
\hline Unit 6 & $\mathrm{n} / \mathrm{a}$ & 12 & $90-100$ & Artiodactyl & 1 \\
\hline Unit 6 & $\mathrm{n} / \mathrm{a}$ & 12 & $90-100$ & Bovinae & 1 \\
\hline Unit 6 & $\mathrm{n} / \mathrm{a}$ & 12 & $90-100$ & Unidentified Mammal & 25 \\
\hline Unit 6 & $\mathrm{n} / \mathrm{a}$ & 13 & $100-110$ & Odocoileus virginianus & 1 \\
\hline
\end{tabular}


Table A-1. continued...

\begin{tabular}{|c|c|c|c|c|c|}
\hline Provenience & Zone & Lv. & Depth (cm) & Taxon & Count \\
\hline Unit 6 & $\mathrm{n} / \mathrm{a}$ & 13 & $100-110$ & Unidentified Mammal & 24 \\
\hline Unit 6 & $\mathrm{n} / \mathrm{a}$ & 14 & $110-120$ & Unidentified Mammal & 4 \\
\hline Unit 6 & $\mathrm{n} / \mathrm{a}$ & 15 & $120-130$ & Unidentified Bird & 4 \\
\hline Unit 6 & $\mathrm{n} / \mathrm{a}$ & 15 & $120-130$ & Unidentified Mammal & 13 \\
\hline Unit 6 & $\mathrm{n} / \mathrm{a}$ & 16 & $130-140$ & Unidentified Mammal & 21 \\
\hline Unit 7 & $\mathrm{n} / \mathrm{a}$ & 1 & $0-10$ & Artiodactyl & 5 \\
\hline Unit 7 & $\mathrm{n} / \mathrm{a}$ & 1 & $0-10$ & Bovinae & 1 \\
\hline Unit 7 & $\mathrm{n} / \mathrm{a}$ & 1 & $0-10$ & Gallus gallus & 2 \\
\hline Unit 7 & $\mathrm{n} / \mathrm{a}$ & 1 & $0-10$ & Unidentified Mammal & 109 \\
\hline Unit 7 & $\mathrm{n} / \mathrm{a}$ & 2 & $10-20$ & Artiodactyl & 1 \\
\hline Unit 7 & $\mathrm{n} / \mathrm{a}$ & 2 & $10-20$ & Bovinae & 4 \\
\hline Unit 7 & $\mathrm{n} / \mathrm{a}$ & 2 & $10-20$ & Unidentified Mammal & 66 \\
\hline Unit 7 & $\mathrm{n} / \mathrm{a}$ & 3 & $20-30$ & Artiodactyl & 2 \\
\hline Unit 7 & $\mathrm{n} / \mathrm{a}$ & 3 & $20-30$ & Bovinae & 2 \\
\hline Unit 7 & $\mathrm{n} / \mathrm{a}$ & 3 & $20-30$ & Ovis aries & 3 \\
\hline Unit 7 & $\mathrm{n} / \mathrm{a}$ & 3 & $20-30$ & Unidentified Mammal & 70 \\
\hline Unit 7 & $\mathrm{n} / \mathrm{a}$ & 4 & $30-40$ & Artiodactyl & 4 \\
\hline Unit 7 & $\mathrm{n} / \mathrm{a}$ & 4 & $30-40$ & Bos taurus & 1 \\
\hline Unit 7 & $\mathrm{n} / \mathrm{a}$ & 4 & $30-40$ & Gallus gallus & 1 \\
\hline Unit 7 & $\mathrm{n} / \mathrm{a}$ & 4 & $30-40$ & Unidentified Bird & 5 \\
\hline Unit 7 & $\mathrm{n} / \mathrm{a}$ & 4 & $30-40$ & Unidentified Mammal & 77 \\
\hline Unit 7 & $\mathrm{n} / \mathrm{a}$ & 5 & $40-57$ & Artiodactyl & 3 \\
\hline Unit 7 & $\mathrm{n} / \mathrm{a}$ & 5 & $40-57$ & Bovinae & 1 \\
\hline Unit 7 & $\mathrm{n} / \mathrm{a}$ & 5 & $40-57$ & Meleagris gallopavo & 1 \\
\hline Unit 7 & $\mathrm{n} / \mathrm{a}$ & 5 & $40-57$ & Sus scrofa & 1 \\
\hline Unit 7 & $\mathrm{n} / \mathrm{a}$ & 5 & $40-57$ & Unidentified Bird & 3 \\
\hline Unit 7 & $\mathrm{n} / \mathrm{a}$ & 5 & $40-57$ & Unidentified fish & 10 \\
\hline Unit 7 & $\mathrm{n} / \mathrm{a}$ & 5 & $40-57$ & Unidentified Mammal & 174 \\
\hline West wall--from mortar & & & & Bovinae & 1 \\
\hline
\end{tabular}





\section{Appendix B}

Macrobotanical Remains Identified from Site 41BX1598 


\title{
Macrobotanical Remains Identified from Site 41BX1598
}

\author{
J. Phil Dering, Shumla Archeobotanical Services
}

This report presents a description of the plant materials recovered from the San Fernando Community Center project (site 41BX1598). The botanical analysis involved examination of eight flotation samples. Wood fragments, nut fragments, and seeds were identified in the samples. Wood types identified include mesquite, juniper, pecan, agarita, and willow/cottonwood. The nut remains were identified as pecan, and the seed type was mesquite.

\section{Methods}

\section{Sorting, Weighing, and Identification}

The analysis followed standard archaeobotanical laboratory procedures. Each sample was passed through a nested set of screens of 4-mm, 2-mm, 1-mm, and 0.450-mm mesh, examined for charred material, and separated for identification. Because plant remains decompose quickly at most open archaeological sites in North America, only carbonized plant materials are considered part of the archaeological record. Carbonized plant materials contain about 35\% elemental carbon, which renders them resistant to bacterial or fungal decay.

Charred wood fragments caught on the 4-mm and 2-mm mesh screens was separated for weighing, counting and identification. In cases where abundant charcoal was recovered from a sample, the charcoal fragments from the 4-mm were separated and identified. Wood charcoal fragments from the 2-mm screens were examined and some pieces large enough to manipulate were identified. In this manner, up to 50 wood fragments were identified within each sample. The remaining material was scanned for seeds, fibers, and other identifiable parts but no attempt was made to identify wood charcoal smaller than $2 \mathrm{~mm}$.

Identification of carbonized wood was accomplished by using the snap technique, examining them at 8 to 45 magnifications with a hand lens or a binocular dissecting microscope, and comparing them to references in the archaeobotanical herbarium.
In most cases, the charred plant material was counted and weighed, however, when more than 50 wood fragments occurred in a sample, the remaining material was scanned for seeds or other identifiable plant remains, then the volume was measured in a graduated cylinder, and weighed.

All floral parts, fruits, nut fragments, and seeds observed in the samples were separated for identification. Nut fragments were first separated into thick and thin pericarp types. Seed identifications were secured using reference material in the archaeobotanical herbarium housed at Shumla Archeobotanical Services.

The anatomy of some woods is so similar that identification to species or even genus is not possible. For this reason, I combine some taxa into wood types. For example, willow (Salix sp.) and cottonwood (Populus sp.), both members of the Salicaceae or willow family, have been placed together to form a single artificial category called a "type".

\section{Results}

Examination of the eight flotation samples from the northern midden (Midden 1) at 41BX1598 resulted in the identification of five tree taxa, one seed type, and one nut type. Carbonized wood was fairly abundant. A total of 225 wood charcoal fragments weighing 13.4 grams was examined for identification. Another 1.6 grams of wood charcoal too small to identify also was recovered from the samples. The five identified wood taxa were mesquite, pecan, juniper, agarita, and willow/cottonwood.

Mesquite wood charcoal weighed 6.3 grams, accounting for $47 \%$ of all the charcoal, including the fragmented material that was too small to identify. Although it occurred in five of the eight samples, juniper charcoal weighed only 0.5 grams. The other three wood types accounted for only a total of 0.3 grams, combined. The wood assemblage, therefore, was overwhelmingly composed of mesquite.

Two nut fragments were noted in FS 85, Unit 5, Zone 2, Level 1. Although measuring only $5 \mathrm{~mm}$ long, these thin nut fragments have the characteristics of pecan shell (pericarp). 
In addition, mesquite seed was recovered from FS 115, Unit 5, Zone 6, Level 1, and FS 119, Unit 5, Zone 7, Level 1. The results of the analysis are presented by field sample number in Table B-1.

Eight stratigraphic zones were sampled in the analysis. Zones 4,6 , and 7 contained the most charcoal, perhaps indicating the most intense activity periods at the site. Charred mesquite seeds were recovered from Zones 6 and 7 (one each), suggesting that these zones were the scene of plant preparation activities, perhaps parching mesquite pods.

The material from Zone 4 was composed almost entirely of mesquite wood charcoal. No seeds or nut fragments were noted in this zone. Pecan nut fragments were recovered from Zone 2, along with a very small amount of pecan wood. Discussion

Table B-1. Plants Identified in Flotation Samples Recovered from 41BX1598

\begin{tabular}{|c|c|c|c|c|c|c|c|}
\hline Cat No & FS & Provenience & Taxon & Common & Part & Count/vol (ml) & Wt. (g) \\
\hline $83-1-1$ & 83 & Unit 5, Zone 1, Lvl 2 & Indeterminate & NA & Wood & 5 & 0.1 \\
\hline $83-1-1$ & 83 & Unit 5, Zone 1, Lvl 2 & Prosopis glandulosa & Mesquite & Wood & 27 & 0.6 \\
\hline \multirow[t]{2}{*}{$83-1-1$} & 83 & Unit 5, Zone 1, Lvl 2 & Salicaceae & Willow/Cottonwoo & Wood & 1 & 0.1 \\
\hline & & & & Total Zone 1 & & 33 & 0.8 \\
\hline & 85 & & & & & 2 & 01 \\
\hline $85-1-1$ & 85 & Unit 5, Zone 2, Lvl 1 & \begin{tabular}{|l} 
Indeterminate \\
\end{tabular} & NA & Wood & $5 \mathrm{ml}$ & 0.8 \\
\hline $85-1-1$ & 85 & Unit 5, Zone 2, Lvl 1 & Juniperus sp. & Juniper, Cedar & Wood & 3 & 0.1 \\
\hline $85-1-1$ & 85 & Unit 5, Zone 2, Lvl 1 & Prosopis glandulosa & Mesquite & Wood & 20 & 0.5 \\
\hline \multirow[t]{2}{*}{$85-1-1$} & 85 & Unit 5, Zone 2, Lvl 1 & Thin Nut-Carya & cf Pecan & Nut & 2 & 0.1 \\
\hline & & & & Total Zone 2 & & $25+5 \mathrm{ml}$ & 1.6 \\
\hline $88-1-1$ & 88 & Unit 5, Zone 3, Lvl 1 & Juniperus sp. & Juniper, Cedar & Wood & 1 & 0.1 \\
\hline \multirow[t]{2}{*}{$88-1-1$} & 88 & Unit 5, Zone 3, Lvl 1 & Prosopis glandulosa & Mesquite & Wood & 17 & 0.2 \\
\hline & & & & \begin{tabular}{|l|} 
Total Zone 3 \\
\end{tabular} & & 18 & 0.3 \\
\hline & & & & & & & \\
\hline $100-1-1$ & 100 & Unit 5, Zone 4, Lvl 3 & Indeterminate & NA & Wood & $4 \mathrm{ml}$ & 5 \\
\hline $100-1-1$ & 100 & Unit 5, Zone 4, Lvl 3 & Juniperus sp. & Juniper, Cedar & Wood & 1 & 0.1 \\
\hline \multirow[t]{2}{*}{$100-1-1$} & 100 & Unit 5, Zone 4, Lvl 3 & Prosopis glandulosa & Mesquite & Wood & 24 & 0.4 \\
\hline & & & & \begin{tabular}{|l|} 
Total Zone 4 \\
\end{tabular} & & $25+4 \mathrm{ml}$ & 5.5 \\
\hline \multirow[t]{3}{*}{\begin{tabular}{|l|}
$104-1-1$ \\
\end{tabular}} & 104 & Unit 5, Zone 5, Lvl 1 & Prosopis glandulosa & Mesquite & Wood & 23 & 0.6 \\
\hline & & & & & & & \\
\hline & & & & & & & \\
\hline $115-1-1$ & 115 & Unit 5, Zone 6, Lvl 1 & Indeterminate & NA & Wood & $4 \mathrm{ml}$ & 0.3 \\
\hline $115-1-1$ & 115 & Unit 5, Zone 6, Lvl 1 & Prosopis glandulosa & Mesquite & Seed & 1 & \\
\hline \multirow[t]{2}{*}{$115-1-1$} & 115 & Unit 5, Zone 6, Lvl 1 & Prosopis glandulosa & Mesquite & Wood & 22 & 1.4 \\
\hline & & & & Total Zone 6 & & $23+4 \mathrm{ml}$ & 1.7 \\
\hline $119-1-1$ & 119 & Unit 5, Zone 7, Lvl 1 & Indeterminate & $\mathrm{NA}$ & Wood & 8 & 0.1 \\
\hline $119-1-1$ & 119 & Unit 5, Zone 7, Lvl 1 & Juniperus sp. & Juniper, Cedar & Wood & 3 & 0.1 \\
\hline 119-1-1 & 119 & Unit 5, Zone 7, Lvl 1 & Prosopis glandulosa & Mesquite & Seed & 1 & \\
\hline \multirow[t]{2}{*}{ 119-1-1 } & 119 & Unit 5, Zone 7, Lvl 1 & Prosopis glandulosa & Mesquite & Wood & 50 & 2.3 \\
\hline & & & & Total Zone 7 & & 62 & 2.5 \\
\hline 121-1-1 & 121 & Unit 5, Zone 8, Lvl 1 & Berberis trifoliata & Agarita & Wood & 2 & 0.1 \\
\hline $121-1-1$ & 121 & Unit 5, Zone 8, Lvl 1 & Juniperus sp. & Juniper, Cedar & Wood & 1 & 0.1 \\
\hline \multirow[t]{2}{*}{ 121-1-1 } & 121 & Unit 5, Zone 8, Lvl 1 & Prosopis glandulosa & Mesquite & Wood & 15 & 0.3 \\
\hline & & & & Total Zone 8 & & 18 & 0.5 \\
\hline
\end{tabular}




\section{Wood Types}

The first impression of the wood charcoal assemblage is that it typifies South Texas Plains vegetation because it includes mesquite, agarita, and pecan, all common trees of riparian margins and open meadows of the region. However, the assemblage includes juniper, which is often thought to be either an invader or an increaser in the region (Taylor 1994). Juniper definitely has spread extensively throughout the southern edge of the Edwards Plateau and adjacent areas, but we are only beginning to obtain a detailed picture of the prehistoric distribution of this plant through examination of flotation samples from archaeological sites.

Oak, a common component of the regional vegetation today, was not identified in the samples, despite the fact that fairly fresh liveoak leaves were noted in four of the flotation samples. This may reflect slight vegetation changes that were already occurring in the early historic period, such as woodland clearing and the intense use of firewood, or it may indicate fuel wood preferences, or simply sample bias.

\section{Mesquite}

Mesquite seeds were recovered from Zones 6 and 7. Mesquite (Prosopis glandulosa) pods have provided a critical source of carbohydrates for thousands of years for people throughout the regions where this very useful plant grows (Felger 1977). Mesquite use by Native Americans was first observed as a food resource in southern Texas or northern Mexico by Cabeza de Vaca (Campbell and Campbell 1981:39). The pod is usually processed by pounding in a mortar as described by Russell (1908), who observed that the beans were pounded with a stone pestle, or if a large quantity was processed, by a wooden one. In southern Texas, mesquite pods were pounded using a large wooden pestle the size of a human leg; and the resulting mesquite flour was mixed with soil into a paste and consumed (Campbell and Campbell 1981:39). In the Sonoran Desert, mesquite provided both the Pima and the Papago with a summer crop in June and a second fall crop in October (Rea 1997:185-186), and mesquite trees often bring forth two bean harvests in south and southwestern Texas.
Pecan

The tremendous potential of pecan as a prehistoric food resource has been assessed by Hall (2000). Nevertheless, pecan is seldom recovered from archaeological sites on the Edwards Plateau, the South Texas Plains, or the Coastal Plains of Texas. Thick lenses of pecan were noted in Baker Cave on the Devils River, but pecan has not been reported from open sites until recently in these regions (Dering 2003). Pecan may not have been previously reported due to the lack of fieldwork and flotation sampling in areas where pecan stands are the densest. It also may be that because pecan has a thinner pericarp (shell), it is under-represented in botanical assemblages from sites excavated in these areas. Pecan use was reported in early historic observations by Cabeza de Vaca (Campbell and Campbell 1981:18), presumably on the Guadalupe River. The reference actually refers to walnut, but pecan is by far the most abundant nutbearing tree in the region and the Spanish did not have a word for pecan at that time. Continued fieldwork in the South Texas Plains area and the Coastal Plains may provide more direct evidence for the use of pecan in the region.

\section{Conclusion}

Despite the fact it apparently dates to the historic period, the plant assemblage from 41BX1598 is distinctly Native American and shows no European influence. Unlike some sites associated with Spanish missions (e.g., Dering 2002), this site contained no evidence of cultigens or imported building material such as pine. For example, considerable evidence of extra-regional plants or Old World cultigens was recorded at Mission Nuestra Señora del Refugio (41RF1), including pine wood, wheat seeds, and peach pits. By contrast, the assemblage from site 41BX1598 is typical of a Native American foraging economy of the Late Archaic or Late Prehistoric periods. 


\section{Appendix C}

Artifacts Recovered during Overburden Removal 
Table C-1. Artifacts Recovered during Overburden Removal

\begin{tabular}{|c|c|c|c|}
\hline Provenience & Class & Type & Count \\
\hline Collection between walls & Activity: Smoking & Unknown & 1 \\
\hline Unidentified Pit & Activity: Smoking & Unknown & 1 \\
\hline Unidentified Pit & Activity: Toy & porcelain & 1 \\
\hline Southwest section of midden \#2 & Bone & & 29 \\
\hline Upper of Midden \#2 Deposit & Bone & & 9 \\
\hline W side of Midden \#2 removal & Bone & & 4 \\
\hline Unidentified Pit & Bone & & 10 \\
\hline Surface Collection & Bone & & 5 \\
\hline CPS Vault Profile & Bone & & 8 \\
\hline Mortar in Colonial Wall & Bone & & 2 \\
\hline Southwest section of midden \#2 & Bone & & 29 \\
\hline Upper of Midden \#2 Deposit & Bone & & 9 \\
\hline W side of Midden \#2 removal & Bone & & 4 \\
\hline Southwest portion of site & Brick & Unknown & 0 \\
\hline Unknown & Brick & handmade & 1 \\
\hline Southwest portion of site & Brick & Unknown & 0 \\
\hline Southwest section of midden \#2 & Burned Rock & & 1 \\
\hline CPS Vault Profile & Burned Rock & & 1 \\
\hline Southwest section of midden \#2 & Burned Rock & & 1 \\
\hline Unidentified Pit & Button & 4-hole shell & 1 \\
\hline Unidentified Pit & Button & 4-hole plastic & 1 \\
\hline Surface Collection & Button & 4-hole porcelain & 1 \\
\hline W side of Midden \#2 removal & Ceramic Tile & unglazed & 1 \\
\hline W side of Midden \#2 removal & Ceramic Tile & unglazed & 1 \\
\hline Southwest section of midden \#2 & Colonial Ceramic: Lead Glazed & sandy paste & 3 \\
\hline Southwest section of midden \#2 & Colonial Ceramic: Lead Glazed & Galera & 1 \\
\hline Upper of Midden \#2 Deposit & Colonial Ceramic: Lead Glazed & sandy paste & 1 \\
\hline Unidentified Pit & Colonial Ceramic: Lead Glazed & sandy paste & 1 \\
\hline CPS Vault Profile & Colonial Ceramic: Lead Glazed & Galera & 1 \\
\hline CPS Vault Profile & Colonial Ceramic: Lead Glazed & sandy paste & 1 \\
\hline CPS Vault Profile & Colonial Ceramic: Lead Glazed & sandy paste & 2 \\
\hline CPS Vault Profile & Colonial Ceramic: Lead Glazed & Galera & 1 \\
\hline Southwest section of midden \#2 & Colonial Ceramic: Lead Glazed & sandy paste & 3 \\
\hline Southwest section of midden \#2 & Colonial Ceramic: Lead Glazed & Galera & 1 \\
\hline Upper of Midden \#2 Deposit & Colonial Ceramic: Lead Glazed & sandy paste & 1 \\
\hline Collection between walls & Colonial Ceramic: Tin Glazed & Puebla Blue on White & 1 \\
\hline Collection between walls & Colonial Ceramic: Tin Glazed & Puebla Blue on W. II & 1 \\
\hline Collection between walls & Colonial Ceramic: Tin Glazed & Guanajuato & 2 \\
\hline Southwest section of midden \#2 & Colonial Ceramic: Tin Glazed & undecorated & 3 \\
\hline W side of Midden \#2 removal & Colonial Ceramic: Tin Glazed & Guanajuato & 1 \\
\hline Unidentified Pit & Colonial Ceramic: Tin Glazed & San Elizario & 1 \\
\hline Surface Collection & Colonial Ceramic: Tin Glazed & Monterey & 1 \\
\hline Surface Collection & Colonial Ceramic: Tin Glazed & San Elizario & 1 \\
\hline Surface Collection & Colonial Ceramic: Tin Glazed & Huejotzingo & 1 \\
\hline Surface Collection & Colonial Ceramic: Tin Glazed & Unknown & 1 \\
\hline CPS Vault Profile & Colonial Ceramic: Tin Glazed & Guanajuato & 1 \\
\hline CPS Vault Profile & Colonial Ceramic: Tin Glazed & Unknown & 1 \\
\hline CPS Vault Profile & Colonial Ceramic: Tin Glazed & San Augustin & 1 \\
\hline Southwest section of midden \#2 & Colonial Ceramic: Tin Glazed & undecorated & 3 \\
\hline W side of Midden \#2 removal & Colonial Ceramic: Tin Glazed & Guanajuato & 1 \\
\hline
\end{tabular}


Table C- 1 . continued...

\begin{tabular}{|c|c|c|c|}
\hline Provenience & Class & Type & Count \\
\hline Southwest section of midden \#2 & Colonial Ceramic: Unglazed & Valero & 1 \\
\hline Southwest section of midden \#2 & Colonial Ceramic: Unglazed & Red burnished & 1 \\
\hline Southwest section of midden \#2 & Colonial Ceramic: Unglazed & burnished & 1 \\
\hline Surface Collection & Colonial Ceramic: Unglazed & Red burnished & 1 \\
\hline CPS Vault Profile & Colonial Ceramic: Unglazed & Tonala & 1 \\
\hline CPS Vault Profile & Colonial Ceramic: Unglazed & Red burnished & 1 \\
\hline Southwest section of midden \#2 & Colonial Ceramic: Unglazed & Valero & 1 \\
\hline Southwest section of midden \#2 & Colonial Ceramic: Unglazed & Red burnished & 1 \\
\hline Southwest section of midden $\# 2$ & Colonial Ceramic: Unglazed & burnished & 1 \\
\hline Southwest section of midden \#2 & Cut nail & & 1 \\
\hline W side of Midden \#2 removal & Cut nail & & 2 \\
\hline Unidentified Pit & Cut nail & & 1 \\
\hline CPS Vault Profile & Cut nail & & 3 \\
\hline Southwest section of midden \#2 & Cut nail & & 1 \\
\hline W side of Midden \#2 removal & Cut nail & & 2 \\
\hline Southwest section of midden \#2 & Debitage & & 4 \\
\hline Under Sewer Disturbance & Debitage & & 2 \\
\hline CPS Vault Profile & Debitage & & 3 \\
\hline Unknown & Debitage & & 1 \\
\hline Southwest section of midden \#2 & Debitage & & 4 \\
\hline Cameron St. Wall Removal & English Ceramic & ink bottle & 1 \\
\hline Unidentified Pit & English Ceramic: Copper Lusterware & & 1 \\
\hline Surface Collection & English Ceramic: Porcelain & Handpainted over glaze & 1 \\
\hline Collection between walls & English Ceramic: Semi-Porcelain & Semi-Porcelain & 2 \\
\hline Unidentified Pit & English Ceramic: Semi-porcelain & dish & 4 \\
\hline Unidentified Pit & English Ceramic: Semi-porcelain & cup & 2 \\
\hline Unidentified Pit & English Ceramic: Semi-porcelain & & 3 \\
\hline Surface Collection & English Ceramic: Stoneware & Unknown & 1 \\
\hline CPS Vault Profile & English Ceramic: Stoneware & & 1 \\
\hline Collection between walls & English Ceramic: White Earthenware & edgeware & 2 \\
\hline Collection between walls & English Ceramic: White Earthenware & Transfer & 3 \\
\hline Collection between walls & English Ceramic: White Earthenware & handpainted & 2 \\
\hline Collection between walls & English Ceramic: White Earthenware & ironstone & 1 \\
\hline Southwest section of midden \#2 & English Ceramic: White Earthenware & edgeware & 1 \\
\hline Southwest section of midden $\# 2$ & English Ceramic: White Earthenware & Creamware & \\
\hline Cellar Area & English Ceramic: White Earthenware & Transfer & 1 \\
\hline Cellar Area & English Ceramic: White Earthenware & spatter ware & 1 \\
\hline Upper of Midden \#2 Deposit & English Ceramic: White Earthenware & Unknown & 1 \\
\hline W side of Midden \#2 removal & English Ceramic: White Earthenware & Unknown & 1 \\
\hline W side of Midden \#2 removal & English Ceramic: White Earthenware & Transfer & 3 \\
\hline Unidentified Pit & English Ceramic: White Earthenware & Edgeware & 2 \\
\hline Unidentified Pit & English Ceramic: White Earthenware & Annular/Banded Slip & 2 \\
\hline Unidentified Pit & English Ceramic: White Earthenware & Transfer & 1 \\
\hline Unidentified Pit & English Ceramic: White Earthenware & Yellowware & 9 \\
\hline Unidentified Pit & English Ceramic: White Earthenware & Yellowware & 11 \\
\hline Unidentified Pit & English Ceramic: White Earthenware & Unknown & 2 \\
\hline Unidentified Pit & English Ceramic: White Earthenware & ironstone & 4 \\
\hline Unidentified Pit & English Ceramic: White Earthenware & ironstone & 1 \\
\hline Unidentified Pit & English Ceramic: White Earthenware & ironstone & 2 \\
\hline Unidentified Pit & English Ceramic: White Earthenware & Unknown & 2 \\
\hline
\end{tabular}


Table C-1. continued...

\begin{tabular}{|c|c|c|c|}
\hline Provenience & Class & Type & Count \\
\hline Surface Collection & English Ceramic: White Earthenware & Unknown & 2 \\
\hline Surface Collection & English Ceramic: White Earthenware & Annular/Banded Slip & 4 \\
\hline Surface Collection & English Ceramic: White Earthenware & Transfer & 1 \\
\hline Surface Collection & English Ceramic: White Earthenware & Unknown & 2 \\
\hline Surface Collection & English Ceramic: White Earthenware & ironstone & 1 \\
\hline Surface Collection & English Ceramic: White Earthenware & Unknown & 2 \\
\hline Surface Collection & English Ceramic: White Earthenware & handpainted & 1 \\
\hline Surface Collection & English Ceramic: White Earthenware & Transfer & 1 \\
\hline Surface Collection & English Ceramic: White Earthenware & sponge stamped & 1 \\
\hline $\mathrm{c}$ & English Ceramic: White Earthenware & Transfer & 1 \\
\hline Surface Collection & English Ceramic: White Earthenware & edgeware & 1 \\
\hline CPS Vault Profile & English Ceramic: White Earthenware & Unknown & 2 \\
\hline CPS Vault Profile & English Ceramic: White Earthenware & Transfer & 1 \\
\hline CPS Vault Profile & English Ceramic: White Earthenware & edgeware & 1 \\
\hline CPS Vault Profile & English Ceramic: White Earthenware & Flow Blue & 2 \\
\hline Unknown & English Ceramic: White Earthenware & Unknown & 2 \\
\hline Southwest section of midden \#2 & English Ceramic: White Earthenware & edgeware & 1 \\
\hline Southwest section of midden \#2 & English Ceramic: White Earthenware & Creamware & 1 \\
\hline Upper of Midden \#2 Deposit & English Ceramic: White Earthenware & Unknown & 1 \\
\hline W side of Midden \#2 removal & English Ceramic: White Earthenware & Unknown & 1 \\
\hline W side of Midden \#2 removal & English Ceramic: White Earthenware & Transfer & 3 \\
\hline W side of Midden \#2 removal & Flat Glass & window & 1 \\
\hline W side of Midden \#2 removal & Flat Glass & window & 1 \\
\hline Cameron St. Wall Removal & Glass & ink bottle & 1 \\
\hline Cameron St. Wall Removal & Glass & knob & 1 \\
\hline Collection between walls & Glass & Unknown & 3 \\
\hline NW portion of site & Glass & ink bottle & 1 \\
\hline Southwest section of midden \#2 & Glass & Unknown & 1 \\
\hline Cellar Area & Glass & Unknown & 1 \\
\hline Cellar Area & Glass & bottle & 1 \\
\hline Cellar Area & Glass & ink bottle & 1 \\
\hline Cellar Area & Glass & wine bottle & 1 \\
\hline Cellar Area & Glass & Unknown & 2 \\
\hline Cellar Area & Glass & Bitters bottle & 1 \\
\hline Cellar Area & Glass & possibly whiskey bottle & 1 \\
\hline W side of Midden \#2 removal & Glass & Unknown & 1 \\
\hline Under Sewer Disturbance & Glass & Unknown & 1 \\
\hline Unidentified Pit & Glass & Unknown & 4 \\
\hline Unidentified Pit & Glass & Unknown & 6 \\
\hline Unidentified Pit & Glass & Unknown & 4 \\
\hline Unidentified Pit & Glass & Unknown & 3 \\
\hline Unidentified Pit & Glass & Unknown & 2 \\
\hline Unidentified Pit & Glass & Unknown & 2 \\
\hline Unidentified Pit & Glass & bottle & 2 \\
\hline Unidentified Pit & Glass & bottle & 1 \\
\hline Unidentified Pit & Glass & Unknown & 1 \\
\hline Unidentified Pit & Glass & bottle & 1 \\
\hline Surface Collection & Glass & crown cap sealing & 1 \\
\hline Surface Collection & Glass & Unknown & 1 \\
\hline CPS Vault Profile & Glass & Unknown & 2 \\
\hline
\end{tabular}


Table C-1. continued...

\begin{tabular}{|c|c|c|c|}
\hline Provenience & Class & Type & Count \\
\hline CPS Vault Profile & Glass & Unknown & 1 \\
\hline Northwest portion of PA & Glass & bottle & 1 \\
\hline Northwest portion of PA & Glass & Unknown & 1 \\
\hline NW portion of site & Glass & ink bottle & 1 \\
\hline Southwest section of midden \#2 & Glass & Unknown & 1 \\
\hline W side of Midden \#2 removal & Glass & Unknown & 1 \\
\hline Southwest section of midden \#2 & Lithic Tool & Biface & 1 \\
\hline CPS Vault Profile & Lithic Tool & biface & 1 \\
\hline Southwest section of midden \#2 & Lithic Tool & Biface & 1 \\
\hline Cellar Area & metal & table knife & 1 \\
\hline Unidentified Pit & metal & identified & 1 \\
\hline Unidentified Pit & metal & fastener, bracelet & 1 \\
\hline Southwest section of midden \#2 & Native American Ceramic & Goliad & 1 \\
\hline Upper of Midden \#2 Deposit & Native American Ceramic & Goliad & 1 \\
\hline Surface Collection & Native American Ceramic & Goliad & 1 \\
\hline Surface Collection & Native American Ceramic & Goliad & 1 \\
\hline CPS Vault Profile & Native American Ceramic & Goliad & 3 \\
\hline Unknown & Native American Ceramic & Goliad & 1 \\
\hline Southwest section of midden $\# 2$ & Native American Ceramic & Goliad & 1 \\
\hline Upper of Midden \#2 Deposit & Native American Ceramic & Goliad & 1 \\
\hline Collection from "cellar" & Other ceramic: Unglazed & flower pot & 1 \\
\hline Cellar Area & Other metal & scissor & 1 \\
\hline basement area & tile & & 5 \\
\hline Southwest section of midden \#2 & Unidentified metal & iron & 1 \\
\hline Cellar Area & Unidentified metal & copper & 1 \\
\hline Southwest section of midden \#2 & Unidentified metal & iron & 1 \\
\hline Surface Collection & wood post & & 1 \\
\hline
\end{tabular}





\section{Appendix D}

\section{History of the "Priest's House" on Military Plaza}




\section{History of the "Priest's House" on Military Plaza}

\section{Waynne Cox}

The concept of the fortified garrisons on hostile borders was an ancient concept, but under Spanish occupation in the vast borderlands, the presidio developed into a vital institution to protect the mission, town, farms and ranches essential to maintain Spain's foothold in the New World. Not only did it serve as a military garrison to protect these elements, but also it evolved to form the nucleus of a town, a market center and the seat of government. ${ }^{1}$ When Spain found it necessary to secure a foothold on the Sabine River in distant East Texas, this pattern of building presidios and misiones was a well-established practice. But within a short time these settlements failed.

One of the few areas of agreement between the Viceroy and the clergy was that the earlier mission effort had failed, in part, due to the difficulty of transporting supplies for them from the distant settlements along the Rio Grande. Therefore, a new presidio was required to serve as a way-station to the mission effort. Governor Don Martín de Alarcón, accompanied by Fray Olivares and seven families of settlers, crossed the Rio Grande on April 9, 1718, to fulfill this purpose. On May 5, 1718, Alarcón, "fixing the royal standard with the requisite solemnity," established the Villa de Bejar, near San Pedro Springs, named in honor of the brother of the Viceroy. ${ }^{2}$ In April of 1721, José de Azlor y Virto de Vera, the Marquis de Aguayo, reached the Villa of Bejar with a force of about 500 men and 4,000 horses and other livestock to reclaim the East Texas missions and establish a stronger defense against the Apaches. Accompanied by the dispossessed friars, the expedition re-established briefly the missions and founded the Presidio Nuestra Señora del Pilar de los Adaes. Upon his return, as Aguayo reached the Trinity River, he was informed that the settlement at Bejar had burned. Sixteen huts and the granary, with its stores of 700 bushels of corn, had been destroyed. Faced with this destruction, upon arrival in San Antonio on January 23, 1722, he ordered that the presidio be relocated to a site between the river and San Pedro Creek (present Military Plaza) opposite the new site of Mission San Antonio de Valero. He designed the fortress "as a square with four bulwarks and curtain walls 65 varas (180.5 feet) in length". ${ }^{3}$ Although his ambitious plan was never fully developed, it served as the nucleus of the new settlement.

In 1726 there were 45 soldiers assigned to the presidio for the protection of an estimated total population of 200. The community continued to grow slowly, despite the reductions of the garrison prompted by the recommendations of Inspector General Pedro de Rivera in 1728, probably because the discharged soldiers remained as settlers. At that time four, settlers and their families lived near the presidio, as did the families of the soldiers. By 1730, the total population was about $300 .{ }^{4}$ This number was increased in 1731 with the arrival of 55 Canary Islanders, recruited by royal order to form the nucleus of the Villa de San Fernando de Bexar, the first civil government in Texas. ${ }^{5}$ In 1772, the Marqués de Rubí recommended that the frontier be reduced to a semi-circular defense line that forced the withdrawal of the presidios of San Sabá, San Agustín de Ahumada, and Nuestra Senora del Pilar de los Adaes. He allowed the presidio of San Antonio to remain, although it was outside the line of defense, making it the northernmost Texas outpost of New Spain. By December of 1790, Pedro Huizar was commissioned to draw plans for the reconstruction of the presidio and improvements of its defenses, but these plans were never implemented. ${ }^{6}$ In 1794, the adjacent mission of San Antonio de Valero (The Alamo) was secularized and the lands distributed to the few remaining mission Indians and other individuals. In 1803, the Second Flying Company of San Carlos de Parras was assigned to reinforce the military force and were stationed on the east side of the river at the abandoned mission. It was during this period that some of the buildings of the old presidio were granted to various citizens of the community.

The northwest corner building of the presidio compound was acquired Maria Josefa Flores y Valdez, who married Miguel Muñez Morillo in 1726. After his death, Maria Josefa married Toribio de Urrutia, who in 1740, succeeded his father as captain of San Antonio de Béxar Presidio, and in 1743 he was justicia mayor of San Antonio. He died on June 26, 1763. In 1778 his widow received a royal grant to her home on San Pedro Creek. ${ }^{7}$ The property was awarded to her grandson, Manuel Nuñez, in $1807 .{ }^{8}$ By 1828 , the property had passed to their heirs, who transferred the property to Father Francisco Maynes. ${ }^{9}$

Francisco Maynes was appointed chaplain of the Presidial and Flying Company of Texas and Coahuila in May of 1808, and chaplain of Compañia Veterano de Béxar in $1822 .{ }^{10}$ He also served as associate priest at San Fernando Church for the community. The "Priest's House," as it became 
known, was also the residence of Father José Refugio Guadalupe de la Garza, who had been appointed the head of the church for Bexar in 1820. ${ }^{11}$ Father de La Garza was one of the few well-educated men in the community, and as such was called to Mexico City in 1822 to help write a constitution for the new independent nation. The following year he contributed to the final secularization of the missions. He also worked on the colonization committee that drafted the legislation that allowed Stephen F. Austin to establish his first colony. ${ }^{12}$ However, he soon developed differences with the new Anglo-Americans, as well as the native Tejanos. Juan N. Seguín's appraisal of him shows the marked division that soon developed:

In the beginning he carried out his duties with great care and decency, and much zeal and dedication to the divine cult. He made notable repairs and improvements to the parish church, for which he gained the appreciation and respect of all the residents. In 1824, when he returned from Mexico City, where his parishioners sent him as deputy to the General Congress, he began to abandon the obligations of his post almost entirely...As far as his religious and moral life, he has done it with so little discretion that almost no one in Béxar is ignorant of his having lived during his entire tenure as priest with various lovers, by whom he has had the following illegitimate children; Concepción, José de Jesus, and Dorotea. He is an enlightened and cultured man. ${ }^{13}$

A major factor in the harsh evaluation of both Fathers de la Garza and Maynes, is that in the sharply divided political scene of the Mexican national period they both remained Mexican Loyalists to the very end. Garza served as a messenger between General Martín de Cós and Stephen F. Austin during the Siege of Bexar, but his continued contact with Mexico gained him accusations of being a traitor. In August of 1840, Bishop John Marie Odin, vice prefect apostolic of Texas, withdrew his priestly facilities, but in September of 1842, the invading General Adrián Woll restored him as parish priest, which only lasted until Woll's retreat to Mexico a few days later. ${ }^{14}$

The general unrest that had been growing among the colonists and Tejanos over the loss of political control and dissention with the Centralist Government of General Antonio López de Santa Anna finally came to a head with the battle of Gonzales on October 2, 1835. The Texian "Army of the People" under Stephen F. Austin prepared to confront the Mexican garrison at San Antonio. Now commanded by General Martín Perfecto de Cós, Santa Anna's brother-in-law, who had arrived in Texas October 20 to reinforce the Army, the garrison numbered approximately 647 effective soldiers. The Texians arrived at Salado Creek on October 19, and placed the town under siege. ${ }^{15}$ However, they found the town well fortified and to assault the town without artillery and stronger numbers would be foolish, so the siege faltered. General Cós had fortified the Alamo and his headquarters on Military Plaza. The fortification on military plaza consisted of the following:

In November, a convention of the colonists at San Felipe declared in support of the Mexican Constitution of 1824, repealed by Santa Anna, and appointed Sam Houston commander of the Army. Austin was authorized to go to the United States to appeal for volunteers and funds. Conditions in the Texan camp at San Antonio had begun to disintegrate. With food running low, clothing inadequate for the approaching winter, and dissatisfied with the lack of action, many began to drift back to the warmth of home and preparation for the spring planting. A council of war overruling Edward Burleson, now in command, voted to withdraw to the safety of Goliad or Gonzales. Benjamin Milam stepped forward and rallied the troops to action. On the morning of December 5, some 300 men in two columns drove into the city from the north. ${ }^{17}$

Their surprise attack allowed them to quickly capture the Garza and Veramendi houses on the north side of town on Soledad Street but intense cannon and musket fire prevented a further advance. The first night and on into the next day they destroyed some buildings around the houses and dug trenches between the two houses they occupied. On the $7^{\text {th }}$, a sharpshooter near the river shot Milam in the head. Frank Johnson assumed command and ordered another night attack, capturing the Navarro house to the south of Military Plaza. On December $8^{\text {th }}$, Colonel Ugartechea returned with 
600 reinforcements. Burleson dispatched an additional 100 Texans into the fight, and they captured the buildings along Zambrano Row, now North Flores Street on the northeast corner of Military Plaza. ${ }^{18}$ Johnson describes the action of that evening:

\begin{abstract}
Near midnight the Captain of the [New Orleans] Grays and Captain Patton, of the Brazoria volunteer, were ordered to storm and carry the priest's house, a strong position on the north side, and near the northeast angle of the civil square. They were exposed to the fire of a battery of three guns and a large number of musketeers. Indeed, so near did they pass under the guns of the wall enclosing the yard of the house, and which had been pierced for musketry, that many of the men had their whiskers and hair burnt by the blaze of the guns, but they advanced steadily and soon carried the position, which gave us command of both squares....Immediately after taking the priest's house, the enemy opened an incessant fire of artillery and small arms against every house in our possession and every part of our lines, which they kept up until near daylight of the fifth day. Immediately after daylight it was discovered that the enemy had hauled down his flag, and hoisted in its stead a white flag. ${ }^{19}$
\end{abstract}

The surrender of the city was soon achieved and General Cós and his troops, the last Mexican soldiers in Texas, were allowed to retire southward, only to return with Santa Anna in February of the following year for the assault on the Alamo.

During these unsettled conditions of the period, Father Maynes mortgaged the house to José Cassiano, born in San Remo, Italy, in 1791. Cassiano moved to San Antonio in the 1820 s and became a prominent merchant. During the siege, his house and store with its supplies was turned over to the revolutionary army. ${ }^{20}$ In 1840 , he sold the house to John Marie Odin, and transferred a clear title to him in $1850{ }^{21}$ The structure appears to have continued to serve as a home for the church clerics, including future bishops Claude Dubuis and John Claude Neraz.
During the Civil War, San Antonio remained the gateway to an untamed frontier, and vigilante justice often prevailed. A young cowboy, Bob Augustine, of DeWitt County arrived during this period to enlist in a company being formed for the Confederate Army. He appears to have consumed too much liquor while awaiting his selection and overturned a number of chili stands in the plaza and terrorized the citizens. $\mathrm{He}$ also was reputed to have stolen a few horses in his time. While he was awaiting trial in the city jail, he was seized by the Vigilantes and hanged from a cottonwood tree in the yard of the priest's house. It is said that after his lynching, the priests cut down the tree because, "they didn't like the fruit it bore." 22 The city jail and courthouse was constructed on the northwest corner of Military Plaza during the administration of Mayor John McDonald, in 1851, and served the city until the construction of the new City Hall in $1892 . .^{23}$

The Sisters of Charity of the incarnate Word originated in Lyons, France, and established in Galveston in 1866, and moved to San Antonio in 1869. Its founder was Claude Marie Dubuis. On December 1, 1869, the Sisters opened the hospital that would be known as Santa Rosa Infirmary. In 1874, the Sisters established their first children's home, St. Joseph's Orphan Asylum in the old priest's house. The following year, their first school, San Fernando School, opened on the site. ${ }^{24}$ It was probably at this time that the old adobe structure was replaced with a two-story, L-shaped cut stone building. Bishop John Neraz, officially transferred the property to the Sisters of Charity on February 19, 1889. ${ }^{25}$ In 1936, the Sisters of Charity conveyed the property to the Missionary Servants of Christ the Master and St. Anthony, and it became St. Anthony School. ${ }^{26}$ In 1957, the property was sold by that body to Hyman Investment Company, and the property remained vacant until 1961 when the buildings were razed and it became a parking facility. ${ }^{27}$

\section{Notes}

${ }^{1}$ Moorhead, M. L., The Presidio: Bastion of the Spanish Borderlands. University of Oklahoma Press, Norman, 1975, pp. 3-4.

${ }^{2}$ Hoffman, F. L. (translator) Diary of the Alarcón Expedition into Texas, 1718-1719. Quivira Society Publications, Volume 5, reprinted, Arno Press, N.Y., 1937, p. 39. 
${ }^{3}$ Santos, R. G., Aguayo Expedition Into Texas, An Annotated Translation of the Five Versions of the Diary Kept by Br. Juan Antonio de la Peña. Jenkins Publishing Company, Austin, Texas, 1981, pp. 75-76.

${ }^{4}$ Teja, J. F., de la, San Antonio de Béxar, A Community on New Spain's Northern Frontier. University of New Mexico Press, Albuquerque, 1995, p. 18.

${ }^{5}$ Webb. W. P. (Editor-in-chief), The Handbook of Texas, Volume 1, The Texas State Historical Association, Austin, 1952 , p. 288.

6 "San Antonio de Bexar Presidio," The New Handbook of Texas, Volume 5, The Texas State Historical Association, Austin, 1996, p. 801.

${ }^{7}$ Chabot, F. C., With The Makers of San Antonio, Privately Published Artes Graficas, San Antonio, 1937, p. 135; "Urrutia, Trobio," The New Handbook of Texas, Volume 6, The Texas State Historical Association, Austin, 1996, p. 679.

${ }^{8}$ Spanish Archives \#1, Judgment 9/22/1807; Spanish Archives \#2, Deed, 3/20/1807, Office of County Clerk, Bexar County Courthouse, San Antonio.

9 José Ramon Guerra, et al to Francisco Maynes, Bexar County Deed Records (BCDR), Volume B2, p. 5, Bexar County, Bexar County Courthouse, San Antonio.

${ }^{10}$ Bexar Archives, reel 38, frames 682-683; reel 73, frames 617-631, Microfilm, John Pease Library, The University of Texas at San Antonio.

${ }^{11}$ Bexar Archives, Reel 63, frame 809.

12 “Garza, José Refugio Guadalupe de la," The New Handbook of Texas, Volume 3, The Texas State Historical Association, Austin, 1996, p.108.

${ }^{13}$ Teja, J. F. de la (editor), A Revolution Remembered: The Memoirs and Selected Correspondence of Juan N. Seguín," State House Press, Austin, 1991, p. 172.
14 "Garza, José Refugio Guadalupe de la," The New Handbook of Texas, Volume 3, The Texas State Historical Association, Austin, 1996, p. 108.

${ }^{15}$ Hardin, S. L., Texian Iliad: A Military History of the Texas Revolution. University of Texas Press, Austin, 1994. p. 25-27.

${ }^{16}$ Johnson, F. W. and Barker, E. C., Texas and the Texans, Five Volumes. American Historical Press, Chicago, 1914, Volume 1, pp. 353-354.

${ }^{17}$ Nevin, D., The Texans, Time-Life Books, New York, 1972 , pp. 72-75.

18 "Bexar, Siege of," The New Handbook of Texas, Volume 1, The Texas State Historical Association, Austin, 1996, p. 516.

${ }^{19}$ Johnson, F. W. and Barker, E. C., Texas and the Texans, Five Volumes. American Historical Press, Chicago, 1914, Volume 1, p. 357.

${ }^{20}$ BCDR, Volume C1, p.106; “Cassiano, José," The New Handbook of Texas, Volume 1, The Texas State Historical Association, Austin, 1996, p. 1015.

${ }^{21}$ BCDR, Volume A2, pp. 348-349; Volume I1, p. 87.

22 Bushick, F. H., Glamorous Days, The Naylor Press, San Antonio, 1934, pp. 245-246.

${ }^{23}$ Cox, I. W., Excavations at the McDonald Site, 41BX794, San Antonio, Bexar County, Texas. Center for Archaeological Research, The University of Texas at San Antonio, Archaeological Survey Report, No. 191; Everett, D. E., San Antonio: The Flavor of Its past, 1845-1898, Trinity University Press, San Antonio, 1975, pp. 129-130.

24 "Sisters of Charity of the Incarnate Word, San Antonio," The New Handbook of Texas, Volume 5, The Texas State Historical Association, Austin, 1996, p. 1065. 
${ }^{25}$ BCDR Volume 79, p. 80.

${ }^{26}$ BCDR Volume1571, p. 58.

${ }^{27}$ BCDR File 111989, Volume 4095, p. 352; File 116757, Volume 4097, p. 45; San Antonio City Directories 1959, 1961. 